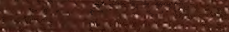




\section{Cornell University Library}

The original of this book is in the Cornell University Library.

There are no known copyright restrictions in the United States on the use of the text.

http://www.archive.org/details/cu31924074445705 


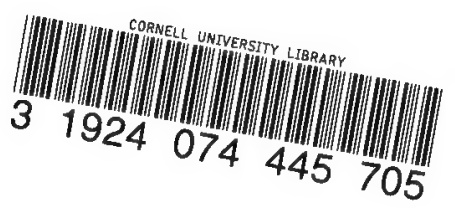





[From Annals of Lyceum of Natural History of $N . Y_{\text {., Vol. V.] }}$

\title{
CATALOGUE OF SHELLS
}

\author{
COLLECTED AT \\ P A N A M A, \\ WITH \\ NOTES ON THEIR SYNONYMY, STATION, \\ AND
}

GEOGRAPHICAL DISTRIBUTION.

\author{
B Y C. B. ADAMS,
}

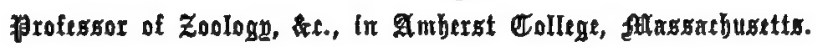

READ BEFORE THE LYCEUM OF NATURAL HISTORY, MAY 10TH, 1852.

N E W Y O R :

R. CRaighead, PRinter, 58 Vesey street.

1852. 

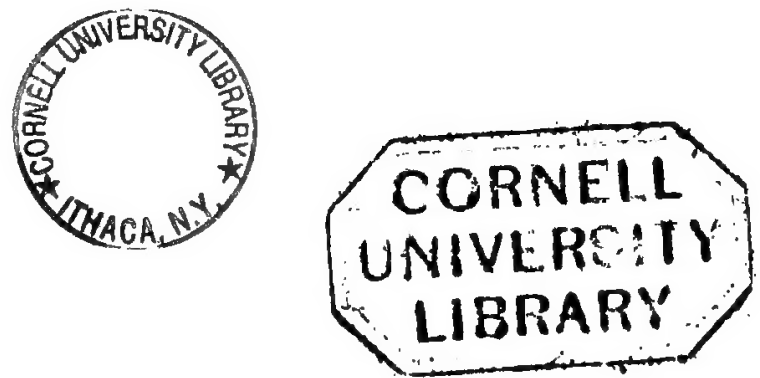


\section{P REFACE.}

THE reader of the Introduction to this work, and of Dr. Gould's Introduction to his great work on the Shells of the United States' Exploring Expedition, may be struck with the coincidence of opinions relating to the geographical distribution of species, and to errors in the statement of their habitats and distinctive characters. The coincidence is so exact, that it might naturally be supposed that these opinions originated in a single source. Such was their origin; but that source was the book of nature. It was not until after both Introductions had been written, that opportunities occurred for a free interchange of views with Dr. Gould. It is therefore with the liveliest satisfaction that we derive assurance of their correctness, both from the extent and accuracy of Dr. Gould's knowledge and also from the coincidence of the results of independent investigations.

With much pleasure I acknowledge my great obligations to JoHN H. REDFIELD, Esq., for his assistance in carrying this little work through the press. The delay in printing the first three or four sheets was so great, that it became necessary to employ another printer and to work off the sheets without revision by the author. Owing, however, to the accuracy of this printer, and to the care of Mr. Redfield, very few, if any, errors worthy of notice appear, which are not chargeable to the manuscript. 
Some errors have been detected, and if many more should not be discovered by others, we shall be agreeably disappointed. We have, however, some confidence that they will not exceed in magnitude those which we have endeavored to eliminate from Conchological literature. All are liable to error: but it may be reasonably expected, that, as in Astronomy rude approximations have been repeatedly corrected with successive advances towards absolute accuracy, so in Zoology the errors respecting geographical distribution and the characters of species will be gradually eliminated. A real advance towards accuracy, however small, will be an ample reward for a labor which has been performed con amore.

For other valuable assistance, especially in the preparation of Indices, I have been indebted to Thomas Bland, Esq.

Some of the sheets having been issued while the work was in press, the dates at the bottorn of the first page of each sheet may be taken for the dates of the publication of the new. species. . । 


\section{CATALOGUE OF WORKS REFERRED TO.}

[In respect of works consisting of many volumes, of whlch only a few have been referred to, we have cited these volumes and their dates only.]

Academy of Natural Sciences of Philadelphia: Proceedings. 1849.

" " " $\quad$ " $\quad$ Journal; old series, vol.ii. 1821.

Annals of the Lyceum of Natural History of New York; vol. i. 1824.

Annals and Magazine of Natural History; vol. viii. 1851.

Annales des Sciences Naturelles; vol. xxvi. 1832; vol. for 1835.

Annales du Muséum; vols. xv., xvi. 1810 ; xvii. 1811.

Annales nouvelles du Muséum; vol. i. 1832.

Anton: Vorzeichniss der Conchylien, \&c. 1839.

Astrolabo, Voyage of: Mollusca. 1830-5.

Beechey's Voyage, Zoology of. 1839.

Bligh Catalogue. 1822.

Blainville: Malacologie et Conchyliologie. 1825.

" Fauna Française; Mollusca.

Bonanni: Recreatio Mentis et Oculi, \&c.; Latin edition. 1684.

Bonite, Voyage of: Mollusca. 1844?

Born: Testacea Musæi Cæsarei Vindobonensis. 1780.

Boston Society of Natural History : Proceedings. 1849, 1851.

British Museum, Catalogue of Anomiadæ in. 1850.

Brocchi : Fossiles Subappenines. 1814.

Brooke: Introduction to the Study of Conchology. 1825.

Buffon: Histoire des Mollusques; vol, v. by De Roissy. 1803.

Burrow : Elements of Conchology. 1825.

Chemnitz: Conchylien Cabinet; vol. iv. 1780 ; x. 1788.

Chenu : Illustrations Conchyliologiques. 1840, 1843, \&c.

"Leçons Élémentaires. 1847.

Children: Lamarck's Genera. 1823. 
Crouch: Introduction to Lamarck's Conchology. 1826.

Cubieres: Ilistoiro des Coquillos.

Da Costa: Elements of Conchology. 1776.

D'Argenville: La Conchyliologie. 1742.

" 1757.

" 1772.

Davila: Catalogue Systćmatique, \&c, 1767.

Dekay: Report on the Zonlogy of New York. 1843.

Deshayes: Traité Elémentaire do Conchyliologie. 1838.

“ Ilistoire Naturelle des Animaux sans Vertèbres, par J. B. P. A. Lamarck; 2e edit, vols. vi.-xi. 1835-45.

" Do.; edit. tert., Bruxellos. 1844.

Dictionnaire des Sciences Naturelles; vols. x., xi. 1818.

Dictionnaire Classique d'Ifistoire Naturellu; vol. v. 1824.

Dillwyn: A Descriptive Catalogue of Recent Shells. 1817.

D’Orluigny: Voyage dans l'Amćrique Méridionale; Mollusca. 1843-6.

Duclos: Ilistoire Naturelle, \&c.; Genre Olive. 1835.

" " "Columbella.

Encyclopédio Miethodịuo; vol. ii. 1824.

$$
\text { " " Vers; vol. ii. } 1830 \text {; iii. } 1832 .
$$

Eschschioliz: Zoological Atlas. 1833.

Favanno: D'Argenville, Ia Conchyliologie. 1780.

Gould: Expedition Shells. 1846-51.

“ Invertebrata of Massachusetts. 1840.

Grily, Mry. . Mollusea. 1860.

Gray: Descriptivo Cataloguo. 1832.

"Spicilegia Zoologicu. 18:28.

Griftith: Cuvier's Animul Kingdom; Mollusea. 1834.

Gualtieri: Index Testarum Conchyliorum. 1742.

Guerin-Meneville: Magnsin de Zoologie, \&c.; vols. of 1833, 1835.

Hanley: Conchologist's Book of Species. 1842.

" Descriptive Catalogue of Recent Shells. 1844, teste Jay.

Heck : Iconographic Encyclopredia; edited by Baird. 1851.

Humboldt: Recueil d'Observations, \&c.; the Mollusea by Valenciennes in vol. ii. 1833.

Jay: Catalogue of Shells; 4th edition. 1850.

Kiener: Iconographie des Coquillos Vivantes. 1834-52.

Knorr: Vergnugen der Augen und des Gemuths; vol. i. 1757; iii. 1768.

Küster: Systematischus Conchylion Cabinet. 1837-51. 
Lamarck: Histoire Naturelle des Animaux sans Vertébres; vols. v.-viii. 1818-22.

Lamarck: Systéme des Animaux sans Vertébres. 1801.

Linnæus: Museum Ludovicæ Ulricæ Sueciæ Reginæ. 1764.

“ Systema Naturæ; edit. 10th, vol. i. 1758.

" " " another 10th edit. 1760.

" " " another 10th edit. 1767.

" " $"$ edit, 12th. 1767.

" " " edit. 13th, by Gmelin. 1788.

" " " Turton edition. 1806.

Lister: Historia Conchyliorum. 1678.

" " " Dillwyn's edit. 1688.

Martini : Conchylien Cabinet; vol. ii. 1773 ; iii. 1777.

Menke: Synopsis Methodica Molluscorum, \&c. 1830.

Montfort: Conchyliologie Systématique, \&c. 1810.

Muiller: Synopsis Novorum Testaceorum, \&c. 1836.

Penny Cyclopadia; vol. viii. 1837; xxï. 1842.

Perry: Conchology. 1811.

Potiez et Michaud: Galérie des Mollusques, \&c., du Museum Douai. 1838.

Philippi: Abbildungen und Beschreibungen, \&c. 1842-50.

Petit: Journal de Conchyliologie. 1850-1.

Reeve: Conchologia Iconica, 1842-52.

"Conchologia Systematica. 1841-2.

* Elements of Conchology. 1846-52.

Revue 7onlogipue; vols. for 1838, 1810-2.

Roux: Iconographin Conchologicu. 1828.

Say: Amerienn Concliology. 1830.

Sehroeter: Einleitung in die Conchylien-Kenntniss, \&c. 1783.

Schubert et Wagner: Supplement to Martini and Chemnitz. 1829.

Schumacher : Nouveau Systéme des Vers Testacés. 1817.

Sowerby, G. B.: Species Conchyliorum. 1830.

" " Catalogue of Shells in the Collection of the Earl of Tankervillo. 1825 .

" G. B., Jr.: Conclıologienl Illustrntions, 1841.

" " Conchological Manual. 1839.

" “ Thesiturus Conchyliorum. 1842-52.

“James: The Genera of Recent and Fossil Shells. 1824.

Stark: Elements of Natural History; vol. i. 1828.

Sulphur, Voyage of. 1844.

Venus, Voyage of: Mollusca. 1846.

Wiegmann : Archiv fir Naturgeschichte. 1839, 1840, 1844. 
Wodarch: Introduction to Conchology; 4th edit. 1831.

Wood: General Conchology. 1815.

"Index Testaceologicus. 1818.

" " " $\quad$ Supplement to. 1828.

" " Hanley's Supplement to. 1845?

Woodward: Manual of the Mollusca. 1851.

Zeitschrift für Malakozoologie, \&c. 1845-51.

Zoological Journal; London. 1825-35.

Zoological Society of London, Proceedings of. 1832-52.

" " " Transactions of; vol. i. 1835. 


\section{INTRODUCTION.}

ON TIIE MARINE zoOLOGICAL PROVINCE OF PANAMA.

Panama is situated near the middle of a well defined marine zoological province. Perhaps none of the species of testaceous Mollusca, (to which part of the Fauna our remarks are limited,) which inhabit the neighboring seas, exist south of $22^{\circ} \mathrm{S}$. lat., or north of $28^{\circ} \mathrm{N}$. lat., or west of the Gallapago Islands. All of the few examples of species, which are supposed to have a wider range, are more or less doubtful. Some species which inhabit the northern part of the province, and others which inhabit the southern part, may overlap the boundaries between this and the adjacent provinces. But these species present only the usual difficulty in attempting to define the limits of a zoological province.

The most definite and satisfactory method of defining the limits of this province, is to place the boundaries at the extreme limits of the range of about 99 per cent. of the species which inhabit its middle regions. Thus it will be seen that several of the species which inhabit Panama also inhabit Guaymas, in the Gulf of California, nearly in $28^{\circ} \mathrm{N}$. lat.; but none of them inhabit San Diego, which is near $33^{\circ}$ N. lat. In the same manner the southern limit is found near the boundary between Peru and Chili, between $22^{\circ}$ and $24^{\circ}$ s. lat.

The reason why the range of the species south of the equator is several degrees less than on the north side, is obvious in the Antarctic current, which sets along the west coast of South America. In like manner, on the eastern 
coast of North America, a polar current appears to extend the Arctic Fauna of marine shells to $41^{\circ} \mathrm{N}$. lat., and the cold current along the shores of the Middle and Southern States seoms to limit the tropical Fauna to about $26^{\circ}$ or $28^{\circ} \mathrm{N}$. lat. on the coast, although on the east side of the Gulf Stream it extends to the Bermuda Islands in latitude $32^{\circ} \mathrm{N}$.

It will be seen also in the following pages, that a large number of the species which oceur at Panama were collected by Mr. Cuming at the Gallapago Islands. But if any of the species occur in the Polynesian Islands, the number does not exceed three or four, and in these cases the specific identity of the shells is very doubtful. The western boundary of the Panama province may therefore be made to include only the Gallapago Islands.

'I'hus, in the language of one hypothesis, climate prevents the dispersion of the species to the north or south; and the Anlaretic current setting over from the coast of l'eru to the Gallapagos, has fuvored their dispersion to those islands, and the broad sea beyond has restrained them from any farther dispersion westward. Perhaps this is as favorable an illustration as can be found of the doctrine of physical causes accounting for the distribution of the individuals of each species rom a single centre. Yet this doctrino is obviously a mere hypothesis. If it be granted that these mollusks can travel coastwise until they find the waters too cold for them, it would still remain to be proved that they actually $d o$ so.

But the supposed dispersion of the species over the sea to the Gallapagos, presents more difficulties than at first appear. The shells of Cirrhopods which adhere to floating wood, have been often found far out at sea; perhaps, too, some species of Pholas may be distributed in this manner. But the only way in which such dispersion of the species generally can be accounted for is by an imaginary voyage of their spawn across the sea. The species, in those stages of growth which have been observed, are mostly restricted to narrow, vertical 
limits, out of which they never have been found. With most of the littoral species, these limits are extremely narrow. The following is a list of the species which we collected at Panama and Taboga, which occur also at the Gallapagos, with a statement of their habits of station.

Cypraa rubescens; under stones.

Mitra tristis; at the depth of 6 to 10 fathoms of sandy mud; also under stones, near low water rnark.

Planaxis planicostata; under stones, between high water and half tide level.

Purpura Carolensis; under stones, at lo water mark.

Columbella atramenlaria; under stones; at low water mark.

Columbella bicanalifera; sandy mudity 10 fathoms water.

Columbella hæemastoma; under stones.

Columbella nigricans; under stones, betw̌ ween half tide and low water mark.

Ricinula Reeviana; under stonos, near low water mark.

Cassis coarctala; in orovices of rocks.

Oniscia tuberculosa; in clefts of rocks, at low water mark.

Conus brunneus; in clefts of rocks, at low water mark.

Conus nux; station unknown.

Strombus granulatus; sandy mud, at the depth of 6 to 8 fathoins.

Turbinella cerala; under stones and in the crevices of rocks, at low water mark.

Pleurotoma excenlrica; coral sand, at the depth of 6 fathoms.

Hipponyx radiata; attached to stones, near low water mark.

Fissurella macrotrema; under stones, on the shore. 
Fissurella nigropunctata; on stones and rocks; at and below half tide level.

Siphonaria gigas; on rooks near half tide level.

Thus it appears that a larger proportion of the littoral than of the pelagic known species are common to the Gallapago Islands and the mainland: and of the pelagic species, all which are known inhabit moderate depths. Locomotion, therefore, beneath the sea cannot be assumed as a probable means of dispersion.

If, however, the distribution is due to dispersion by the floating of the spawn westward, along with the prevailing winds and currents, it is remarkable that there are no well authenticated examples of olearly identical species which are common to the Gallapagos and to the Polynesian Islands. In respect of species, which so ncarly resemble each other as to be sometimes confounded, and which are by some authors regarded as varieties produced by local conditions, the West Indies furnish as many of these analogues to the Panama species as have been found in Polynesia. There is, therefore, no reason for referring the Polynesian analogues to a continental origin.

If such dispersion westward wero a fact, then wo ought to find, as we go westward from the Pacific shores of America, a continual accumulation of speciess. For, in addition to the full complement of aboriginal species in any reyion, there would be a per centage of immigrant species. If snch dispersion were a common fact, the Gallapagos should be much richer in species than the continent, and the western regions of Polynesia and the Australasian Archipelago should contain a great number of immigrant species in addition to their ab. original Faunæ. But there are no facts which correspond with such hypotheses. So far as is known, the Bay of Panama is as rich in species as any region westward, with no more 
than an equal variety of sta.tions. The number of species in any region appears to be connected only with climate and variely of stations.

It is scarcely necessary to consider the question, whether any of the shells on the opposite sides of tropical America could have had a common origin. Although in some points the Caribbean sea and the Pacifio approach within 40 or 50 miles in a direct line, it is difficult to imagine any adequate means of the intercommunication of living marine mollusks. If human agency had transplanted any species, we should have expected that the edible species would have been selected. The following are some of the edible Caribbean species, in the order in which they have appeared to us in Jamaica to be most commonly used: Trochus pica, Pyrula melongena, Ostrea folium, Arca Noe, (or an undescribed analogue of this species), Strombus gigas, Turbo cœlatus, Avicula crocata, \&o. At Panama, the edible species which we observed are in the same order, Arca tuberoulosa, Venus discors, Ostrea, two or three species, Arca grandis, Murex radix, Pyrula patula, \&c. All of these are remarkably distinct, if we except the Pyrula, whioh are analogues. If it should be supposed that the analogues might have had a common origin, it will be seen that the entire list of analogues comprises a full proportion of the rare or minute species, which are not likely to have been noticed by the inhabitants.

Birds are commonly called in to aid the imaginary dispersion of species. On the Isthmus, the buzzards are best able, with their extraordinary powers of flight, to transport them; but their habits of feeding are wholly at variance with such a supposition. The water birds which feed on the marine mollusks are unknown to us. But if their agency has been effective, it is remarkable that we can identify only one species, and that doubtfully, (Crepidula unguiformis), on both sides of the Isthmus, and that the habits of this mollusk, at- 
tached to dead shells within the aperture, render it one of those which are least exposed to such accidents.

The following is a list of the principal pairs of analogues which inlabit both sides of the Isthmus. The list might be increased, especially by comparision of the very minute species. But the group, as it is, presents such a variety in respect of size and characters, of habits of station, tenacity of life, \&o., as to render it incredible that they all should owe their distribution in pairs to a common process of transportation. Cyprea cervinetta occurs only beneath large rocks, at the low water mark of the spring tides, and lives but a short time when removed from the water, and Strombus gracilior is pelagic; and the others live at or near low water mark on rocks, under stones, in sand, in fine mud, \&c. In general the derivation. of analogues from a common stock is moreover inconsistent with the existence of analogues which are antipodes to each other.

Panama.

*Jamaica.

Cypræa cervinetta;

C. exanthema.

Marginella minor;

M. minima.

M. sapotilla ;

M. prunum.

Mitra nucleola;

M. granulosa.

Oliva araneosa;

O. reticulata.

$O$. venulata ;

0 . soripta.

Purpura undata ;

P. fasciata.

Columbella guttata ;

$\left\{\begin{array}{l}\text { C. cribraria Lam. } \\ \text { C. parvula Dunker. }\end{array}\right.$

Cassis abbreviata ;

C. inflata.

Oniscia tuberculosa;

O. oniscus.

Strombus gracilior :

Triton vestitus;

S. pugilis.

Murex erosus ;

T. pilearis.

Pyrula patula;

M. intermedius.

P. melongena.

\footnotetext{
- These Oarribbean species have all been collected by us in Jamaica.
} 
Panama.

Jamaica.

Turbinella cæstus ;

T. muricata.

Cerithium assimilatum ;

C. terebellum.

Fissurella microtrema;

F. sp. indet.

Arca gradata ;

Cytherea squalida;

A. Domingensis.

Capsa altior ;

C. maculata.

Tellina sp. indet. ;

C. Brasiliensis.

T. bimaculata.

The number of known species of shells which occur in the Panama province, probably is not far from 1500 . The actual number is undoubtedly much greater.

An examination of the catalogue of the species which we collected in the Bay of Panama, will show that nearly all the very minute species are new to science, although most of the larger shells have been described. In other words, the species which are as small as those which constitute a large portion of the conchological Fauna of regions, which have been thoroughly explored, have been overlooked by previous collectors. This is by no means surprising, when we consider the great number of species, and the abundance of their individuals, which are of a size that is more convenient for discovery and collection. It is also accounted for in part by the fact that the minute species in this region are much more rare in individuals. Yet the new species, which were collected in six weeks at two localities, must be a very small portion of those which actually exist in this zoological province. Perhaps, therefore, the number of the undiscovered species is equal to that of the known species.*

* After describing nearly sixty new and rather small Pleurotomoid shells which had been collected during the royage of H. M. S. Sulphur, Mr. Hinds observes, "when we reflect what multitudes of similar beings inhabit the recesses of the globe, beyond the reach of human observation, and which at rare intervals are brought to light, * * it requires the boldest stretch of the imagination even to bring within the comprehension an idea of the countless multitudes of organised beings of our earth, and all rich in some manner peculiarly their own, either in color, sculpture, decoration, or symmetry." -Hind's Zool. Voy. Sulph. Moll. p. 24. 
On the Eastern side of the continent, a totally distinet marine zoological province, which may be called the Caribbean province, occupies about an equal part of the earth's surface. It has however, a much greater extent of coast, in the great number of islands, and in the sinuous outlines of the continent. The number of known species of shells in this province is not far from 1500 . The actual number probably is less than in the Panama province. It is a remarkable fact that the number of rather large species in the Caribbean province is but a small fraction of the number of such species which occur on the other side of the continent. Of the Caribbean species, very few occur north of the Bahamas, or south of Brazil, although, from various sources of error many of them have been reputed to inhabit England, and various other parts of the world. Althuugh there are several analogous species in the two provinces, in general there is a great dissirnilarity.

\section{Conchological Collector's in the Panama Province.}

One of the earliest collectors in this zoological province was Joseph Dombey, the well known French Botanical traveller. Dombey arrived in Peru, on his botanical expedition, in April, 1778. $\mathrm{He}$ is quoted by Lamarck for eight new species of shells from Peru.

Baron Huinboldt, and his companion, M. Bonpland, next made collections of the shells. In 1803 they were on the coast of Peru, whence they sailed to Acapulco. Here they collected many species, of which eleven are described by Lamarck in the Animaux Sans Vertebres. The first volume of Humboldt's Recueil D'observations de Zoologie, \&c., was published in 1811 ; but the second volume in which the shells are described by M. Valencienres, bears the date of 1833. Of the 92 species mentioned 88 are described in full, and of the 92 all but 3 or 4 are said to inhabit this province. In 
the case of several species however, errors have evidently crept in. Either the species must have been derived from other regions and were given to the travellers as natives, or the describer has oonfounded analogues. The Columbella rustica, mentioned with doubt, may have been a C. fuscata. Cassis testiculus, which inhabits only the West Indies, Ranella granifera, Pyrula ficoides, Pyrula vespertilio, and Solarium granulatum, which inhabit the Indian ocean, are said to have been collected at Acapulco. Perhaps the ancient extensive commerce between Acapulco and the Philippine Islands may have introduced, into the dwellings, at Acapulen, specimens of East India shells.

Next we find in the supplement to Wood's Index several species from the same province, and most of them were collected at Panama.

In Feb. and March 1823, the Coquille (French) was at Callao and Payta. M. Lesson has enumerated 8 marine species of shells collected here, none of which are identical with our Panama shells.

But we are chiefly indebted for a lknowledge of the shells of this region to the well known expedition of Hugh Cuming, Esq. This celebrated collector, who has in person collected one-third of all the species of shells now known to science, was occupied in the years 1827-30 in collecting the shells of this province and of adjacent parts of the Polynesian and southwest American shores. Besides previously known species, 400 new speoies were collected, of which a large majority were obtained at the Gallapagos and on the western shores of tropical America. His explorations comprised, in fact, the whole of this zoological province, with the exception of its northern extremity. The description of the new species was commenced by the London Conchologists in the Proceedings of the Zoological Society, Feb. 28, 1832, and were continued for about four years, until the second and great expodition of 
this gentleman to the Philippines. Subsequently more of them have appeared in the Proceedings of the same Society, in Sowerby's Thesaurus Conchyliorum, and especially in Reove's Conchologia Iconica. In these last two works, we find the habitats of all, and the stations of most of the species collected by Mr. Cuming, so far as the genera have been monographed.

The laborious and productive travels of the Chev. Alcide D'Orbigny during the years 1826-33, comprise a portion of this zoological province. In July 1833, this gentleman reached the Pacifio coast at Arica by a journey across the Andes. Embarking thence on the 25th, he stopped at Cobijo, Islay, Arequipa, and Callao. Re-imbarking here, this industrious traveller returned to Europe by way of Valparaiso.

In the large quarto which D'Orbigny has devoted to the Mollusoa of South America, numerous species of shells are described from the four marine faunæ. Among them are many which were collected by $\mathbf{M}$. Fontaine, and by $\mathrm{Mr}$. Curning, and others. The tropical and the temperate marine faunæ of the west and east sides are shown to be entirely distinct in respect of the Mollusca, of which 628 species are enumerated, there being only one species common to any two of these provinces. But it is conjectured that collections made near the southern extremity of the continent on both sides might show that several species are there common to the Atlantic and Pacific faunæ. The species common to both sides is Siphonaria Lessoni, found at Montevideo and at Callao. Other species, however, are said, in the body of the work, to inhabit both sides of the continent, as Bulla slriata. But in this case, analogous species may have been confounded. Since Dr. Philippi has shown that several species had been confounded under this name, the specific types are found to be as local as most species are. D'Orbigny is one of the very 
few travellers who have collected any of the very minute shells of the tropics.

In 1836-37 the Bonite (French) made a voyage of exploration around the world. In the summer of 1836 this expedition touched at several places in the southern part of the Panama zoological province, as far north as Guayaquil, whence the Bonite sailed for the Sandwich Islands. M. M. Eydoux and Souleyet were the zoologists of the expedition. The former gentleman died of yellow fever at Martinique in 1841 , before the results in this department were published. On the Mollusca we have seen only a folio volume of about 50 plates, without date and without text. The only text of the zoology which we have seen, is on the mammals and birds, with date of 1841.

In August, and during the remainder of $1836, \mathrm{H}$. M. S. the Sulphur, under Lieut. Commander Kellett, visited Callao and Payta, and carefully explored the coast from Guayaquil to Panama. Here Commander (now Captain Sir Edward) Belcher arrived and took command, and in collecting shells was aided by Mr. Hinds, surgeon of the expedition. The dredge was frequently used, and the cabin of the commander became a museum. Proceeding to the north, they visited numerous places up to San Blas, in June 1837. In the following December, the Sulphur returned to the coast; and explorations were made from Acapulco to Cerro Azul. Again in the latter part of 1838 , and during much of 1839 , colleotions were made in many localities. About 70 new species were desoribed by Mr. Hinds in the Proo. Zool. Soo. of London, commeneing February 14, 1843; also in the Zoology of the voyage of H. M. S. Sulphur; and they have been included in monographs which have subsequently been published in London.

In 1837 the Venus (French) was at Callao from May 24 to June 3 ; from Nov. 25 to Dec. 6 at the Bay of Magdalena, in the peninsula of California; from Deo. 12 to Deo. 18, at 
Mazatlan; Dec. 21 to Dec. 27 at San Blas; Jan. 8, 1838 to Jan. 23 at Acápulco; May 10 to June 1 at Callao; June 5 to June 17 at Payta; June 23 to July 3 at the Gallapagos. The Atlas de Zoologie of this expedition, (pub. 1846) eontained 24 folio plates, of shells and mollusca. The text we have not seen.

In 1839 the U. S. Exploring Expedition tonched at Callao, which was the only place in this zoological province, that was visited by the expedition. About 30 species of shells were collected, of which four new speoies have been described by Dr. Gould in the Proceedings of the Boston Society of Natural History since 1846.

In the Zeitschrift fur Malakologie of Aug. 1847, Dr. K. 'T. Menke commenced a catalogue, with descriptions of the new species, of the shells of Mazatlan. These shells were collected by Mr. Henry Melchers of Bremen, who has spent several years in Mazatlan. Additions have sinoe been made to the catalngue, and up to Feb. (inc.) 1851, Dr. Menke has catalogued 173 Mazatlan species. Of these 26 are described as new species, not including a few which were proposed as new but have since been identified by Dr. Menke with previously described species.

At the present time Dr. Gould is engaged in the examination of speoies, which have been colleoted at various points between Sun Franciseo and Mazatlan. These cullections were made by Maj. William Rich, and Col. E. Jewett, U. S. A., and by Lieut. Thomas P. Green, U. S. N. They are the more impurtant, because they come from regions intermediate between two great zoologioal provinces, and we may hope therefore that Dr. Gould will show, with as much precision as the facts themselves will admit, the boundary between them. At a meeting of the Boston Society of Natural History, September 3,1851 , Dr. Gould read descriptions of 17 new species of Acephala from these frontier regions. The collections made 
by Lieut. Green merit especial notice. 'This officer collected more than 200 species, and carefully noted the habitat of the speoimens. Of those which have been determined by Dr: Gould, and which were also found by us at Panama, we have incorporated into the following paper the habitats observed by Lieut. Green. This collection proves conclusively that Upper Califurnia belongs to a distinct Zoological province.

The shells collected by Nuttall in Upper California in 1836, and described in the Journ. Acad. Nat. Scs. of Philadelphia, VII, in 1837, confirm this inference. None of them are identical with the species which inhabit Panama.

\section{Narrative of the Expedition.}

In November, 1850, I left home with the design of spending a few weeks on the Isthmus of Panama, and the remainder of the winter in Jamaica. Leave of absence not having been granted until Nov. 6, the preparations were few and hasty. On the afternoon of the 13th I sailed from New York in the Steamer Empire City, Captain J. D. Wilson,* and on the morning of the 22nd, landed at Chagres. Most of that day was occupied in rambling about the shores. A few shells were found of the same species, which occur throughout the Caribbean seas. But near Chagres the shores are too much exposed to sustain many species of Mollusks. In the afternoon, Captain Knight, his clerk, and myself hired a boat and started for Cruces, where we arrived on the evening of the 25th. The

* Since it must be confessed that American naturalists find little eympathy with their pursuits among most of their countrymen of all classes, it affords me the more pleasure to ackmowledge my obligations to the owners of the Steamer, Messre. J. Howard \& Son, for a passage to Chagres; and to Capt. Wilson for various attentions on the voyage, and subsequently at the monthly visits of the Steamer to Jamaica. To Capt. E. Knight, agent of the Pacific Mail Steam Ship Co., and my travelling companion across the Isthmus, I was especially indebted for unusual facilitics in crossing, as well as for other aid. Good company, and the extraordinary beauties of nature, more than compensated for four days saturation in mud and water during the transit. 
next day we rode to Panama, where I soon found myself at home in the American Hotel.* Before $8 \mathrm{~A}$. MI, of the next day, shells had been collected in such quantity and variety, that, had nothing more been subsequently collected, the results of the expedition woull have seemed ample.

The objects proposed to be accomplished, during a few weeks at Panama, were the following :

1. To make collections for the Museum in Amherst College. The original plan had embraced the Crustacea, Radiata, and other animals, but the short time to be devoted to it, and especially the impossibility of making suitable preparation during the few hours, which were allowed for this purpose, rendered it expedient to restrict the objects mainly to the collection of shells.

2. A second object was to ascertain, with the certainty of personal observation, what and how many species of shells exist at Panana. Having formerly collected about $500 \mathrm{ma}$. rine species in Jamaica, near the centre of the Caribbean Zoological province, it was thought that a comparison of these authentic materials would not be without interest. These two were the principal objects of the expedition.

3. A subordinate object was to make some ubservations on the habits of the species, in respect of station. Mr. Cuming's careful explorations had left but little to be added, but that little is therefore perhaps the more valuable. This knowledge was also a necessary preliminary to the acquisition of such a quantity of specimens as would fully illustrate the varieties, which may exist within the limits of a species. But these observations, could not be extended to the pelagic species on account of the enormous expense of boating consequent on

* With James C. Staples, Esq, the proprietor, an old acquaintance and con. nection, who with his partner, myself, and all my Mollusks, occupied as comfort able an apartueut as the place could furnish. 
the California travel. Littoral explorations however, produce a greater amount of results in a short time.

It has become so fashionable to undervalue a knowledge of the shells of Mollusca, because the shell is only a part o the animal, that we shall probably be censured for having neglected to observe the soft parts. But non omnes omnia possumus, especially with only six weeks time. It will not bo denied that the existence of the species is sufficiently proved by collecting the shells, nor that their geographical distribution may be learned, when we ascertain where they exist, nor that habits of station may be learned without dissection, although this is indispensable for some objects, - nor that the recondite questions on the origin of the species are intimately connected with the facts of distribution and station,- - nor even that the number of species in a given region and the abundance or scarcity of individuals are interesting features in the plan of creation. In short, it will not be denied that the sum total of Zoology consists of parts, and that the perfection of the whole may be better secured by a division of labor. Wo hope therefore, that the following results, notwithstanding the magnitude of the deficioncies, will bo regarded as somewhat better than the only alternative before us, -that of the stay-at-home collectors.

The situation of Panama is eminently favorable for the collection of shells. At the head of an extensive bay, whose waters well merit the appellation of Pacific, it stands also at the head of a reef, which furnishes a great variety of station for the mollusks. Our hotel was within a minute's walk of this reef. In front of the city, the reef consists of ledges of trachytic rocks, with flat and concave surfaces, with gently sloping, precipitous, or shelving sides : in other parts extensive tracts are covered with loose fragments of rook, the different sizes of which, and the different degrees in which they are buried in sand, or in which they havo open spaces be- 
neath, accommodate a great diversity of species: in some parts, flats of mud or of sand prevail.

On the west of the city is a very broad gently sloping beach of fine sand, where Oliva, Tellina, Donax, and Artemis abound. Then proceeding westward we find alternating ledges of trachytic and basaltio rocks, sand beaches, and broad muddy or sandy flats, with groves of trees a little above half tide level. Here during the recess of the tide, the oollector finds an agreeable shade, and gathers Purpuræe and huge Littorinæ from the trees, and numerous species of $\mathrm{Ve}$ neridae, of Columbella, the little and elegant Veritina picta, and sometimes the massive Arca grandis, among the sticks and moss-like Algae beneath. Three miles west of Panama a Rio Grande enters the bay, and is bordered by impenetrable thickets of mangroves and not impenetrable ooze.

On the east side of Panama is a steep sand beach, at the bottom of which the flats consist of an impalpable mud of a oreamy consistence. On this fluid, Marginella sapotilla orawls or rather glides rapidly about. Between two and three miles to the East, there are ledges of smooth basaltic rocks, with abundant Littorinae, Fissurellae, and Siphonariae. Here too are marine groves, rising from a stony surface, by the side of which a small rivulet comes in. At high water mark is a mangrove thicket, beneath which in near proximity we find the Potamides, Arcæ, a large Cyrena, Potamomyæ, and the elegant Auricula conoinna, and over head is Littorina pulchra, but almost as rare as beautiful. A little farther up, where the water is nearly fresh, occurs the Neritina Guayaquilensis, whose thin depressed elliptical shell attests its fluviatile habits, unlike the solid ellipsoidal shell of the marine N. picta.

This diversity of station was multiplied by the high tides. In the office of the Pacific Mail Steamship Co., wo saw it recorded on a tide table, that the extreme difference of high and low water had amounted to 28 feet. The ordinary tides 
are about sixteen to twenty feet. The difference between the spring tides and the neap tides amounts to from four to six feet. Hence at the low water mark of two or three tides, once cach fortnight, species of shells, as well as of Echinoderms and other animals, may be obtained, which cannot be procured at any other time except by dredging. Other species live where every tide will leave them exposel to the air for a short time. All the way from low water mark, up to the ledges of rocks where some species of Littorina live out of the reach of the highest tides, species are found, most of which are limited to a very narrow vertical zone. The surface in front of the city, which is ? eft bare by the recess of the tide, extends out half a mile or more. Thus over several square miles the secrets of the ocean may be explored.

The bay of Panama contains several beautiful islands, which rise as steep mountains directly from the water's edge. One of these is Taboga, ${ }^{*} 12$ miles from Panama, from and to which a small American steamer runs daily. We made two excursions of three days each to this island. The shores are mostly steep, but sand beaches, ledges, and enormous fragments of rocks, afford many favorable stations for the Mollusks. At high water, a small island, on the northeast side, is cut off from the principal island; but at low water a bigh ridge of sand unites them. Here the elegant Conus Mahogani, Strombus Peruvianus, Natica otis, Corbula ovulata, \&o., were found.

These varieties of station enabled us to find a multitude of species in their proper haunts: But in addition to this advantage, the hermit crabs (Paguridae) swarmed here, as elsewhere in tropical regions. Some of the smaller species have the habit of congregating in heaps of many hundreds

* This name is sometimes written, erroneously we believe, Tabago; and sometimes, in the publications of the London Conchologists, Saboga. 
beneath stones. Many such heaps were collected in the mass, to be culled over in the leisure of home. To this source we are wholly indebted for many species of shells, not a few of which are in such a good state of preservation that wo have to regret only the impossibility of describing the station of these species.

In these Pacific waters, not much addition to the stores of the collector can be made from the drift shells. Yet the flow of the tides and a moderate surf brought several species within reach. Several of the bivalves, which live buried in sand, and whose station eluded discovery, were thus obtained. But especially were we indebted to this source for the extremely minute species, several of which were not recognised until the conchiferous rubbish and sand had been assorted with sieves and then carefully examined.

From the natives we obtained but little aid. The shells of a few edible species were taken from heaps near their huts. A few species were obtained in a fruit shanty, which was kept by an American on the Plaza. The habitat of most of these was verified by subsequently finding them on the shores. That of four or five species was satisfactorily inferred, indepently of the testimony, from the fuct that no shells known to inhabit other regions were seen in the shanty, and that these species have been fuund by others in the same zoological province. Those which were thus obtained are mentioned accordingly in the statement of habitat.

In a few instances it will be noticed that our account of the station differs somewhat from Mr. Cuming's. This is due chiefly to the considerable range which some species have, especially with different circumstances of place. Thus several of the species, which we found at the low water mark of spring tides, were obtained by Mr. Cuming at the depth of fifteen or more fathoms. The difference between such stations is obviously of much less importance than that between 
this extreme low water mark, where the air will but slightly reach the animal every fortnight, and that of a few feet higher, whence the water wholly recedes twice every day.

Having an opportunity of shipping the collections, which filled eight cases, we wrote the bills of lading, Jan. 3, 1851, and the next morning left Panama for Chagres and Jamaica. It was not until Aug. 14 that the cases arrived at their destination. After assorting the shells, we find 38.920 specimens of 376 species of Gasteropoda, 2.860 specimens of 139 species of Acephala, and 50 specimens of 1 species of Brachiopoda : total, 41.830 specimens of 516 speoies of Mollusks. The number of specimens of each species is mentioned in the following pages. It is scarcely necessary to add that we have stated the total number of individuals, to give approximately an idea of the relative abundance of the species at the time and places mentioned, and not of such specimens as amateurs would pronounce ' good shells.'

In the following catalogue our principal object, after the enumeration of the species, has been to collect the statement of various writers concerning the habitats and stations of the species. Where two names of persons follow the habitat or station, the first is usually that of the person who collected the species, and is followed by an exclamation mark! The second name is that of the author who is quoted. The (!) after a single name indicates that the author was also the collector; but the absence of this mark indicates that the testimony is not original, whether one or more names are cited.

It will be seen that for a knowledge of the stations we are chiefly indebted to Mr. Cuming.

In appending synonymy, we have quoted nothing. The references have been made chiefly as vouchers for the accuracy of the names of the species, and as means of detecting errors. A subordinate object has been the convenience of those friends among whom the duplicate specimens may be 
distributed. We have been under obligations, which we acknowledge with much pleasure, to Dr. A. A. Gould, of Boston, and to John II. Redfield and Robert I. Stuart, Esqrs, of New-York City, for the use of books; also to the librarians of the Boston Athenæum, of Harvard University, of the Acad. Nat. Sciences, of Philadelphia, and to Dr. Henry Wheatland, of the Essex Institute in Salem; chiefly have we been indebted to the nearly complete zoological library which Drs. T. B. and Edward Wilson have presented to the Academy of Natural Sciences of Philadelphia.

\section{On Errors Respecting the Habitat of Species.}

Those who are familiar with the frequency and magnitude of the errors, which occur in the works of the most celebrated authors respecting the habitats of speoies, will not probably accuse us of presumption for the little ceremony with which we have treated such statements. Hearsay testimony has often been received without sufficient scrutiny. In addition to the errors likely to occur in the verbal communication of statements respecting habitat, naturalists at home are of course subject to all the mistakes which the original colleotors may have made. These persons often mix the collections made in various places, and depend on memury for the localities, although they are often unable to distinguish the spocies when placed side by side.*

Another class of errors, we fear, must be laid to the charge of the writers themselves. When we seo a marine species affirmed to inhabit the Mediterranean, Senegal, the Indian

- Thus we have received from an intelligent shipmaster, who was accustomed to collect for a conchologist, specimens of Cyclostoma flavidum, witl the positive assurance that they were collected in a spot well known to us, not far from Kingston, Junaicr. Yet the species occurs only in Porto Rico, while the locality in Jumaica containg a Oylindrella of similar aspect. We may be allowed to mention also an illustration of the manner in which mistakes of locality and not of species 
Ocean, New Holland, \&o., we may often suspect the error to arise more or less from erroneous testimony. But when one species is referred to two distinct zoological provinces, which are known to contain analogous but not identical species, we must sometimes suspect the author of confounding such species. If indeed in these cases the difference of the local types were clearly distinguished, it would be of little importance whether or not the difference were considered to be of specific value. But not even after the specimens are deposited in a collection has all danger of error ceased. A misplacement of labels or of shells, which are not properly secured, may lead to erroneuus statements of habitat.

For all these causes of error there is but one remedy, and that is not infallible. Rejecting the testimony of careless and incompetent observers, and all hearsay testimony, we must rely on the testimony of competent observers. Wo may hope for accuracy when they shall remember that a very few errors may essentially change the aspect of the plan of distribution, and prevent all correct generalizations.

A great amount of valuable materials, for interesting generalizations on the number and distribution of the species of marine Mollusks, has been collected by public and private expeditions. But when we consider the immense profusion of species and of individuals in tropical seas, and the confusion of the habitats of many as exhibited in the present literature of concliology, so that the plan of distribution is misrepresented,-that which has been done only stimulates

may happen in casual coll | ions. By a singular coincidence, only a few days after we had described Helix hedfieldiana (whicls proves to be H. Carmelita Fer.) that inhabits a limited district in Jamaica, u specimen was brought to Now-York by a collector, who affirmed that he procured it in California. Subsequently the statement was repeated, but afterwards it was recollected that the shell had been purchased in Kingston, where the steamers stop on their homeward voyage. 
the curiosity to know more and to know more accurately. An expedition of oircumnavigation, with the specific object of investigating the distribution of the testaceous Mollusks, through several tropical marine provinces, would accomplish more than the discovery of many new species : it would determine the distribution of a much greater number, in a manner which would justly inspire confidence.

Index of Places in the Pacific, which are mentioned in the Catalogue of Panama Shells.

Arapulco. A town and harbor, in Mexico; it is the principal and best port of Mexico on the Pacific; lat. $16^{\circ} 55^{\circ}$ N.; long. $100^{\circ} 54^{\prime} \mathrm{W}$.

Annaa. An islind in Polynesia. Probably Anna or Aana, or Chain Island; lat. $17^{\circ} 20^{\circ} \mathrm{S}$. ; long. $145^{\circ} 40^{\prime} \mathrm{W}$.

Arica. In Peru.

Atacamas. A senport in Equndor, on the Pacific.

California. The boundary betwoen Upper and Lower Culifornin is near lnt. $83^{\circ} \mathrm{N}$. 'I'he waters of Upper Californin, therefore, belong wholly to the temperato Fauna, and those of Lower Califurnin almost wholly to the tropical Fauna. Tho Fauna of the Gulf of California is tropical, at least as far as Guayrias. The importance in znolo:y of distinguishing between Upper and Lower Califurnia, in statements of habitat, is therofore obviuus. New Albion was a name given by Sir Francis Drake, to an extent of const which includes upper California and Oregon, and is often used more indefinitely.

Callao. The port of Lima, capital of Peru; lat. $12^{\circ} 2^{\prime} \mathrm{S}$.; long. $76^{\circ} 58^{\prime} \mathrm{W}$.

Caraccas, Bay of. A small bay on the coast of Guaynquil, next north of Cape San Lorenzo, between $2^{\circ}$ and $1^{\circ} \mathrm{S}$. lat.. It is not mentioned in any of the Gazetteers which we have consulted. It is also called Manta Bay.

Central America. This name is used very indefinitely by some conchological writers. It includes on the Pacific, only Guatemala, San Salvador, Nicaragua, and Costa Ricn, from about lat. $9^{\circ} \mathrm{N}$. to $15^{\circ} \mathrm{N}$. The whole country was called Guatemala before its independence.

Cerro Azul. A town in Peru, in the department of Lima.

- Charles $I$. One of the Gallapagos, at the southwest part of the group.

Chatham I. One of the Gallapagos, at the southenst part of the group.

Chili. Its northern boundary, about $24^{\circ} 20^{\prime} \mathrm{S}$. lat., is not far from the southern limit of the tropical Fauna.

Chiloe. A large island in the southern part of Chili, between $42^{\circ}$ and $44^{\circ} \mathrm{S}$. lat.

Chivigui. A town in Veragua, Central America, on the P'acific side; lat. $8^{\circ}$ $80^{\circ} \mathrm{N}$.; long. $83^{\circ} 28^{\circ} \mathrm{W}$. 
Columbia, West. New Grenada, reaching from about $2^{\circ} \mathrm{S}$. lat. to $8^{\circ} \mathrm{N}$. lat. ; including Guayaquil on the South. It is frequently written Colombia,

Conchagua. Another name for the Bay of Fonseca; also the name of a volcano near the same place.

Costa Rica. A province of Central America, between Nicaragua on the north, and Veragua on the southeast. The Gulf of Nicoya penetrates the middle portions; it lies between about $8^{\circ} 30^{\prime}$ and $10^{\circ} 40^{\prime} \mathrm{N}$. lat.

Cusma. A town on the coast of Peru; lat. about $9^{\circ} 40^{\prime} \mathrm{S}$.

Fonseca, Gulf of. Also called Amapalla and Conchagua. A spacious harbor in Central America; lat about $13^{\circ} \cdot \mathrm{N}$

Gallapago Islands. A group lying under the Equator, with the line of $86^{\circ} 30^{\circ}$ W. long. passing through the central island. They are uninhabited. They are about 600 nautical miles from the mainland.

Guacomayo. In Central America.

Guayaquil. A town, gulf, dc., in lat. $2^{\circ} 11^{\prime} \mathrm{S}$.

Guaymas. A town in Mexico, on the East side of the Gulf of California, in lat. about $28^{\circ} \mathrm{N}$.

Honda, Bay of. A small bay next west of Montija Bay, in Veragua, in about $7^{\circ} 45^{\circ} \mathrm{N}$, lat.

\section{Islay. In Peru.}

Isthmus. Sc. of Panama.

Lambeyeque. A town on the coast of Peru; lat. $6^{\circ} 45^{\prime} \mathrm{S}$.

La Paz. A town or mission in Lower California, on the west gide of the Gulf, - in lat. nbout $24^{\circ} 30^{\prime} \mathrm{N}$.

Lobos $I$. Near the const of Peru, in lat, about $6^{\circ} 40^{\prime} \mathrm{S}$.

Lord Hood's $I$. Hood's $\mathrm{I}$., in the southeast part of Polynesin, in atout $22^{\circ} \mathrm{S}$. lat. and $195^{\circ} \mathrm{W}$. long.

Magdalena, Bay of. In Lower California, on the Pacific side, in lat, about $24^{\circ}$ $40^{\prime} \mathrm{N}$.

Mazatlan. A town in Mexico, near the entrance of the Gulf of California, in lat. about $23^{\circ} 20^{\circ} \mathrm{N}$.

Mexico, Occupying the Pacific shore from lat. about $83^{\circ} \mathrm{N}$. to $15^{\circ} \mathrm{N}$, from Upper California to Central America.

Monte Christi. A town in New Grenada, in the province of Guayaquil; lat. n'3)';

Montijo, Bay of. In Veragua, on the south side, next west of the Bay of Panama.

Muerte, Isle of. In the Bay of Guayaquil.

Nicoya, Gulf of. In Costa Rica, lat, between $9^{\circ}$ and $10^{\circ} \mathrm{N}$

Pacosmayo. Probably in Central America. 
Panama. A town, propince, bay, \&c., in New Grenada. The town is in lat. $8^{\circ} 49^{\prime}$, N. long. $8^{\circ} 21^{\prime}$ W.

Papagayo, Gulf of. In Central America, between Costa Rica and Nicaragua, in lat. about $11^{\circ} \mathrm{N}$.

Payta. A town in Peru, in lat. $5^{\circ} 15^{\prime} \mathrm{S}$.

Peru. Occupying the Pacific shore from New Grenada to Chili, from about $4^{\circ}$ S. lat. to $25^{\circ} \mathrm{S}$. lat.

Plata, Isle of. On the coast of Guayaquil, in lat. $1^{\circ} 10^{\prime} \mathrm{S}$.

Polynesia. Comprising most of the tropical regions of the Pacific.

Puerto Portrero. In the Bay of Guajaquil.

Puna, Isle of. In the Bay of Guayrquil; about $3^{\circ} \mathrm{S}$. lat.

Punta St. Elena. A cape on the coast of Guayaquil, in lat. about $2^{\circ} 10^{\prime} \mathrm{S}$.

Quito I. In the Bay of Guayaquil.

Real Llejos, or Realejo. A port in Nicarngua, serving as a harbor to Leon, lat. $12^{\circ} 43^{\prime} \mathrm{N}$.; long. $87^{\circ} 46^{\prime} \mathrm{W}$.

Rio Grande. A name given to many rivers by the Spaniards. The one referred to is a small stream near Panama.

Saboga. An error, for Taboga.

St. Elena. A town on the coast of Guayaquil, in lat. about $2^{\circ} \mathrm{S}$.

Salango. On the coast of Guayaquil, about $1^{\circ} 80^{\prime} \mathrm{S}$.

San Blas. A town on the west const of Mexico, lat. about $22^{\circ} \mathrm{N}$.

San Diego. A town on the coast of Upper. Califurnia, one league from the southern boundary; lat. $33^{\circ} 12^{\prime} \mathrm{N}$.; long. $116^{\circ} 53^{\prime} \mathrm{W}$.

San Francisco. The principal port of Upper California ; lat. about $\beta 7^{\circ} 20^{\prime} \mathrm{N}$.; long about $122^{\circ} \mathrm{W}$

San Juan. A bay on the east side of Lower Oalifornia, in lat. about $27^{\circ} \mathrm{N}$.

San Lorenzo. A cape on the coast of Guayaquil, about $1^{\circ} \mathrm{S}$. lat.

San Salvador. A city in Central America, on a river, twelve miles from the const; also an adjacent district along the coast.

Santa Barbara. In California.

- Sitcha. An island on the coast of Russian America, in lat. $57^{\circ} \mathrm{N}$.

South Seas. An indefinite term for more or less of the Pacific Ocean adjacent to America.

Taboga. A small island twelve miles southwest of Panama. It has a better harbor than Panama, and is the depot of the Pacific steamers.

Tahiti. The largest of the Society Islands; lat. $17^{\circ} 30^{\prime} \mathrm{S}$.; long. $149^{\circ} 20^{\prime} \mathrm{W}$.

Toobouai. A small Polynesian island, under the southern tropic, in lat. about $150^{\circ} \mathrm{W}$.

Tumbez. A town near the northern extremity of the coast of Peru; lat. $3^{\circ} 40^{\circ}$ S. ; long. $79^{\circ} 51^{\prime} \mathrm{W}$.

Veragua. The southeastern province of Central America, between Costa Rica and the fathmus of Panama.

Xipixapi. A town on the west coast of New Grenada; lat. about $1^{\circ} 30^{\circ} \mathrm{S}$ 
Family-CYPRÆID正.

OVULA.-M. Kiener's monograph of this genus contains only 23 species, but Mr. Sowerby, in Thes. Conch., describes 48 speoies, besides 4 from the west coast of tropical America, which were described in the Proo. Zool. Soo. Lond., 1832, and figured in the Conch. Illust., but which "seem to have been overlooked when his monograph was published in 1849. Some of Mr. Sowerby's habitats of the species are so comprehensive, that we oannot suppress the suspicion of some error, either in the testimony on this point, or in confounding allied species. Especially are we perplexed by the habitat assigned. to the well-known and very distinct Caribbean species, $O$. gibbosa, "collected at Panama by Mr. Cuming." Dr. Jay, however, in the last edition of his catalogue, mentions (copies?) the same habitat. The general question of the identity of any speoific types on both sides of the Isthmus is of so muoh importance as to require a oareful sorutiny into all statements of such identity.

\section{Ovula avena.}

Synonymy.

Ovulum avena Sowb. Proc. Zool. Soc. Lond. p. 173. - Oct. 1832. Müll. Synop. Nov. Test. Viv. p. 128. May 1836. Sowb. Catal. Cyp. p. 17. No. 28. - 1841. - Sowb. Conch. Ill. pl. 8. f. 59. 1841 .

Our shells are somewhat smaller than the figure here quoted. This is one of the species omitted in the Thesaurus.

if Station.-We found this Mollusk on a small speoies of Gorgona at the low water mark of the spring tides.

Habitat. "In America Centrali, (Conohagua.)"-Cum. ing! Sowerby in Proo. Z. S. 
"At Conchagua in Mexico."-Cuming ! Sowerby in Catal. Cyp.

Mexico.-Jay.

Santa Barbara.-E. Jewett! Gould MSS.

Panama._C. B. A.!

We obtained six specimens on the reef at Panama. The second quotation contains a geographical error. If this is copied by Dr. Jay, wo have only two habitats, besides Panama. Conchagua is another name for the Gulf of Fonseca.

\section{Ovula cmarginata.}

\section{Synonymy.}

Ovulum emarginatum Sowb. Spec. Conch. Part I., p. 7,

$$
\text { f. 54, 55. - - - - Nov. } 1830 .
$$
Gray Descr. Catal.p. 19. No.161. June 1832.

Ovula emarginata Kienor Iconog. p. 18. pl. 3. f. 2.

Ounlum emarginatum Sowb. Thes. Conch. p. 479. No.

39. pl. 09. f. 11. 12 . 1848 .

Of our three perfect specimens, one is covered with fine revolving striæ over the whole of the back, not excepting the keel; another, over all but the keel, as in the fig. in Sowb. Thes. ; the third is smooth over the middle portion, as in Kiener's figure.

Station.-Unknown.

Habitat.-Unknown.-Sowerby in Speo. Conch. : also Kiener.

St. Elena._Cuming! Sowerby in Thes. Conch.

St. Elena.-Jay.

Panama.-C. B. A. !

In the Species Conchyliorum, Mr. Sowerby says, "the only specimen of this rare species I have seen is in Mr. Bland's collection." We were indebted to the hermit crabs for six 
specimens, of which three are quite perfect. They were found on the reef at Panama. A fragment of a seventh was found on the beach.

\section{Ovula Neglecta.-Nov. sp.}

Shell rather slender : dark violaceous red, sometimes with as light tinge of brown; paler on the lip : smooth, sometimes with microscopio revolving striæ: aperture very narrow in the posterior three-fifths, wider anteriorly; slightly produced at both extremities, and slightly emarginate anteriorly : lip well thickened, nearly straight along the middle : columella acuminate at both extremities, with a longitudinal impressed line, and a callus behind it. Length, .31 inch; breadth, .1 inch.

This species resembles the fig. of $O$. rufa, Sowb, which is represented as much larger, with a broader aperture.

Station.-With O. avena, which see.

Habitat.-Panama.-C. B. A. !

We collected 13 specimens on the reef.

\section{Ovula Variabilis.-Nov. sp.}

Shell very slender: usually white, with a slight tinge of rufous, with the lip opaque white; sometimes of a rich red purple: smooth : aperture not very narrow, a little widened anteriorly, moderately produced, effuse, and slightly inflected posteriorly ; obliquely emarginate anteriorily : lip well thickened : columella with a longitudinal keel, acute and obliquely produced anteriorly, posteriorly somewhat biplicate. Length, .54 inch; breadth, .15 inches.

This shell resembles $O$. inflexa, Sowb., but is more slender. Perhaps on comparison of specimens, they may be proved identical. O. uniplicata, Sowb., is larger, with a wider aperture. 
Station.-At the low water mark of the spring tides. The light colored specimens were found on a cream-colored speoies of Gorgonia, and the purple specimens on a Gorgonia of the same color. Of 56 specimens, four are purple, and 14 are rnature, and 42 immature.

Habitat.-San Juan, Lower Calif.-Lt. Green! Gould Mss. Purple shells.

Santa Barbara.-E. Jewett! Gould Mss. Pale, or moderately tinged with purple.

Panama.-C. B. A. !

The 56 specimens were all taken on the reef at Panama. Mr. Cuming found one specimen of $O$. inflexum in the Gulf of Dulce.

\section{Ovula ; sp. Indet}

We abstain from describing this species, because the only two specimens which we have are immature. They resemble $O$. variabilis, but the general form and the aperture are wider, and the shells are covered with excessively minute revolving striae. Except in being striated, they resemble $O$. inflexum Sowb. They were found on the reef.

CTPRA A. Of the seven following species, all appeared to be rare atPanama, except $C$. punctulata and C. cervinetta.

\section{Cypraea arabicula.}

\section{Synonymy.}

Cyproea arabicula Lam. in Ann. Mus. XVI. 100. No. 54. 1810.

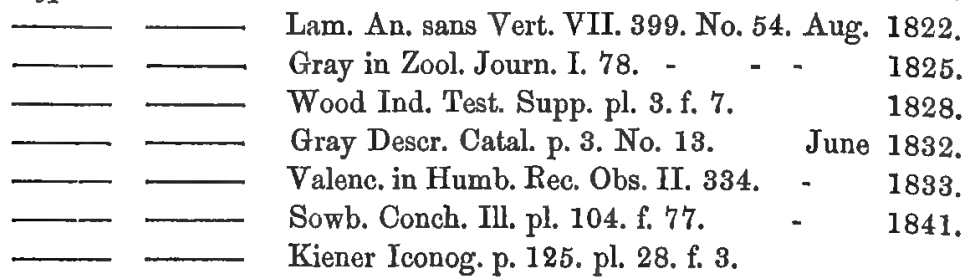


CYPR EA.

Cyproea arabicula Lam. An. sans Vert. X. 534. No. 54. Desh.

Ed.

Reeve Conch. Icon. pl. 13. f. 60. - Dec. 1845.

One of our specimens, which is large and very deeply colored, has the dark brown dorsal lines so confluent, as to resemble C. reticulata. It is 1.37 inch long.

Station.-Under stones; Cuming! Reeve.

Our specimens were under stones, which were from about eight to twenty inohes in diameter, at and just below the low water mark of the neap tides.

Habitat.-Western shores of Mexico, at Acapulco; Humboldt \& Bonpland ! Lamark.

South Seas; Wood.

Acapulco ; Humboldt \& Bonpland! Valenciennes.

Brazil ; Ravenel in Catalogue.

St. Elena and Real-Llejos ; Sowerby.

Mexico ; Gray.

Western shores of Mexico, near Açapulco; Kiener.

St. Elena; Cuming ! Reeve.

Mazatlan; Melohers! Menke.

St. Elena; Jay.

Panama ; C. B. A !

We collected 7 specimens on the reef.

\section{Cypraea cervimetta.}

Synonymy.

Cyproea exanthema var. \& Gray in Zool. Journ. I. 139.

1825.

var. $\beta$,

"

1825.

$\longrightarrow$

cervinetta

Kiener Iconog. p. 74. pl. 6. f. 1. 2.

Desh. in Lam. An. sans Vert. X. 547.

No. 71.

1844.

exanthema Hinds in Voy Sulph. p. 6

1845.

cervus var. Reeve Conch. Icon.

Nov. 1844.

Mr. Reeve regards this species as merely a variety of $C$. cervus, and has well described its peculiarities of color. But the 
more important difference is in its form, which is scarcely distinguishable from that of $C$. exanthema. Although there is a prevailing type of coloring in each of these three species, it is rather less constant than the form, so that $C$. cervinetla is some: times liable to be confounded with $C$. exanthema, until we observe the aperture, which is like that of $C$. cervina. The latter is ventricose, rather thinner, with the aperture dilated anteriorly ; C. cervinetta is subcylindric, with the aperture as in $C$. cervina: C.exanthema is subcylindrio, with the aperture narrow anteriorly, and the right lip more bent upwards anteriorly.

Station.-At and just above the low water mark of the spring tides, this species was found under stones which were not less than fifteen or twenty inohes in diameter.

Habitat.-Caribbean Sea, and shores of Senegal: Kiener. Indian Ocean? Deshayes.

Indian Ocean; Jay.

Panama, and I. of Taboga: C. B. A !

The words of Kiener are "Habite l'océan des Antilles et les côtes du Sénégal." Since no authority is given for this habitat, and since gross errors of habitat are common in Kiener's Iconography, we must be allowed to regard the statement as wholly erroneous. Some varieties of C. exanthema, which is a Caribbean species, might be mistaken for $C$. cervinetta, and thus lead to the belief that the latter is also Caribbean. But C. exanthema is exclusively Caribbean; C. cervinetta we believe occurs only in the Panama provinoe, as we have above defined this province; and C. cervus probably belongs to the Polynesian zoological province. We have indeed received a specimen of C. cervinetta from the Sandwich Islands; but at these islands it is a common custom to collect shells from the whale ships. The habitat assigned to the species by Deshayes (copied by Dr. Jay?) is probably due to hearsay testmony.

Probably the "C. exanthema" found by Mr. Hinds at the island of Muerte belongs to this species. 
We collected 115 specimens, mostly on the reef at Panama, but partly at Taboga.

\section{Cypraea punctulata.}

\section{Synonymy.}

Cyproea punclulata Gray Zool. Journ. I. 387. 1825 .

- Gray Descr. Catal. p. 10. No. 86. June 1832.

\begin{tabular}{llr} 
& I. 484. pl. 35. f. 11, 12. & 1838. \\
\hline- & Sowb. Conch. Ill. pl. 4. f. 20. & 1841. \\
& Kiener Iconog. p. 114. pl. 21. f. 2. & \\
& Desh. in Lam. An. sans Vert. X. \\
& 563. No. 92. - - - - & 1844. \\
& Reeve Conch. Icon. pl. 13. f. 61. - - Dec. 1845.
\end{tabular}

Specimens differ in size and color. Very elegant light colored specimens ocour rarely. One shell is 1.3 inch long and .88 inch wide; another is .7 inch long and .48 inch wide.

Station.-Under stones; Cuming! Reeve.

We found it with $C$. arabicula, which see.

Habitat.-Unknown; Potiez and Michaud.

Panama; Cuming! Sowerby : also Reeve.

New Holland; Gray.

Shores of Peru and of New Holland; Kiener.

Panama; Deshayes: also Jay.

Panama, and I. of Taboga ; C. B A.

Gray and Kiener must be in error in citing New Holland as a habitat of this species. We oollected 335 specimens, mostly on the reef at Panama, and partly at Taboga.

\section{Cypraea pustulata.}

\section{Synonomy.}

Lister Conch. t. 710. f. $62 . \quad-\quad$ - $\quad 1678$.

Schrot. Einl. Conch. I. 146. - - 1783.

Cypraea pustulata Lam. Ann. Mus. XVI. 101. No. 58. - 1810. 


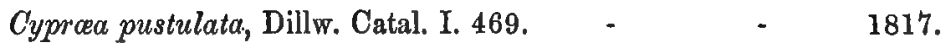

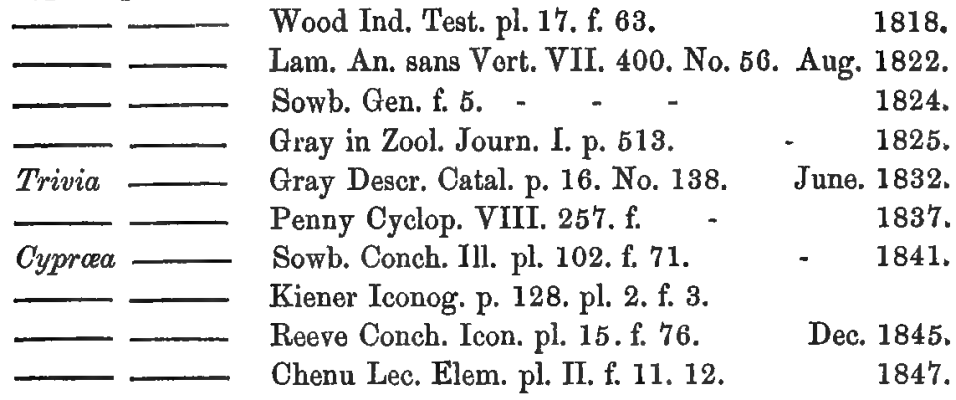

Specimens differ much in size : one is 1.04 inch long, and .6 inch wide; another is .55 inch long, and .33 inch wide. But we have never seen a specimen as large as Mr. Reeve's figure, which is 1.22 inch long and .73 inch wide.

Station.-Under stones; Cuming! Reeve.

We found this speoies alive under large stones, at the ex. treme low water mark of the spring tides only.

Habitat.-Coasts of China, according to Humphreys; Acapulco, according to Lamarck; Dillwyn.

China; Wood.

Western shores of Mexico, at Acapulco; Humboldt and Bonpland ! Lamarck.

West coast of Mexico; Say in Catal. Mus.

Panama and Isle of Plata, Mexico; Sowerby. Pacifio Ocean; Gray : also Penny Cyclopedia.

Western shores of Mexico, near Acapulco; Kiener.

Isle of Plata and Panama, west coast of America ; Cuming! Reeve.

Mazatlan; Melchers! Menke.

Panama; Jay.

Panama; C. B. A.

The oitation of China, as a habitat of this species, is an error due probably to hearsay testimony. The Isle of Plata mentioned by Sowerby and by Reeve is probably the island of 
that name, off the coast of Guayaquil, near Cape San Lorenzo, in latitude $1^{\circ} 10^{\prime}$. It is only 4 miles long and 11.2 broad. Mr. Sowerby's reference to Mexico is unintelligible. Two specimens received by us from a German conchologist, are said to have conse from Chile, but this is a very doubtful habitat.

We collected 8 living specimens at the end of the reef at Panama, and 20 dead shells in the vicinity.

\section{Cypraea radians.}

Synonymy.

Davila Catal. I. pl. 15. f. 1.

1767.

Cyproea radians Lam. Ann. Mus. XVI. 102. No. 62.

1810.

- oniscus Wood Ind. Test. pi. 17. f. 58.

1818.

- radians Lam. An. sans Vert. VII. 402. No. 62. Aug. 1822.

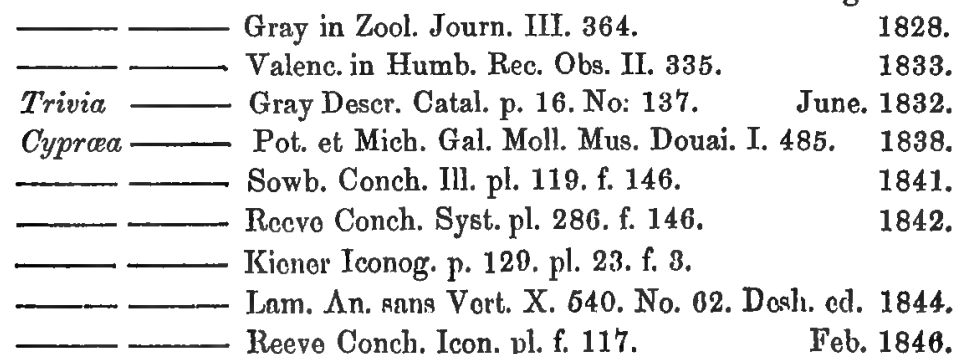

In the Supp. of Wood's Ind. Test. C. oniscus has received by transposition the name of C.radians.

Station.-Under stones; Cuming! Reeve.

Habitat.-Adriatio; Wood.

Western shores of Mexico, at Acapulco; Humboldt and Bonpland! Lamarck.

Pacific Ocean; Gray.

Acapulco ; Humboldt and Bonpland! Valenciennes,

Chili ; Ravenel in Catalogue.

Western shores of Mexico, near Acapulco; Kiener.

Chili, Western shores of Mexico; Potiez and Michaud. 
St. Elena ; Cuming ! Reeve.

St. Elena; Jay.

Mazatlan; Lt. Green! Gould Mss.: also Mus Essex Inst.

Panama; E. Jewett! Gould Mss.

Panama; C. B. A !

Wond is obviously incorrect. It may be doubted also whether the species inhabits Chili. We found near Panama only 2 dead specimens.

\section{Cypraea rubescens,}

Synonymy.

Cypraea rubescens Gray in Proc. Zool. Soc. Lond. p. 185. Nov. 1832. Reeve Conch. Icon. pl. 25. f. 14.1.

Feb. 1846 .

Stalion.-Under stones ; Cuming! Gray : also Reeve.

Habitat.-Gallapago Islands; Cuming! Gray : also Reeve. Panama; C. B. A !

We found 1 dead but perfect specimen on the beach next east of Panama.

\section{Cypraea sanguinea.}

Synonymy

Trivia sanguinea Gray Descr. Catal. p. 14. No. $119 . \quad$ June. 1832.

Cyprcea - Sowb. Catal. Cyp. p. 12. No. 115.

1841 .

Sowb. Conch. Ill. pl. 6. f. 32.

Desh. in Lam. An. sans Vert. X. 570. No. 102.

Desh. ed.

1844.

- Reeve Conch. Icon. pl. 23. f. 127.

Feb. 1846 .

Chenu Lec. Elem. pl. 10. f. 9, 10.

1847.

Station.-Under stones; Cuming! Reeve.

Habitat -Panama and Mexico; Sowerby.

Pacific Ocean; Gray: also Deshayés.

St. Elena; Cuming! Reeve.

Mazatlan; Melchers! Menke. 
St. Elena ; Jay.

Panama; E. Jewett! Gould Mss.

Panama; C. B. A!

On the beach east of Panama, we found 1 dead but perfect shell of this species.

\section{Erato scabriuscula.}

Synonymy.

Erato scabriuscula Gray Descr. Catal. p. 16. No. 140. June. 1832. Marginella cyprocola Sowb. in Proc. Zool. Soc. p. 57. March ? 1832. - granum Kiener Iconog. p. 17. pl. 8. f. 33. Erato scabriuscula Sowb. Catal. Cyp. p. 15. No.1. 1841. - Sowb. Conch. Ill. pl. 7. f. 45. - - Reeve Conch. Syst. pl. 285. f. 7, 10. 1842.

By some mistake a species of Trivia is figured for this species in the Penny. Cyclopedia, VIII. 25\%.

Station.-Under stones and in sandy places; Sowerby. On the rocks; Kiener.

We found fine perfect specimens alive under stones near low water mark. Kiener's statement, that they live on the rooks, is probably erroneous. Like Cypreas, they seek concealment.

Habitat.-St Elena; Gray.

"Sainte Hélene ;" Kiener.

Acapulco ; Cuming; Sowerby.

St. Elena ; Cuming ! Sowerby.

Acapulco; Sloat! Redfield Mss.

Mazatlan; E. Jewett! Gould Mss.

Panama; C. B. A !

We found 1 young, and 3 mature shells on the reef at $\mathrm{Pa}$ nama. Although we turned over many hundred stones in the search, no more could be found.

Our specimens exhibit the pliciform columellar teeth, and the pustulous enamel of the surface in full development. M. 
Kiener's figure represents a mature specimen, probably not an old one, with the columellar teeth not fully developed. We are indebted to Mr. Redfield for the gift of his best speoimon, which appears to be full grown and perfect without the pustulous surface. Col. Jewett also collected several specimens of the same variety at Mazatlan. Perhaps the acquisition of this character is the last change which the shell undergoes.

\section{Marginella minor. Nor.sp.}

Shell ovate: whito, or pale horn color, subtransparent; rather thin, smooth: spire slightly elevated: whorls about three (?) with a very indistinct suture : aperture linear : lip rather thin at the margin, thickened behind, posteriorly asscending the spire: columella with two well developed plaits at the end, with a third one less developed, and sometimes with a fourth which is more or less indistinct. Length, 09 inch: breadth, .063 inch: some of our specimens, which appear to be full grown, are much smaller.

This little shell closely resembles tho Caribbean species, M. Lavalleana Orb. (M. minima Guild,): the most obvious differenoe is in the outline, which in the Caribbean species is broader across the upper part of the last whorl, the lip consequently being, at this part, more excurved.

Station.-Unknown.

Habitat.-Panama ; C. B. A !

We obtained 10 more or less perfect specimens from the calcareous sand, which had been washed up near the sea wall of Panama.

\section{Marginella sapotilla.}

Synonymy.

Marginella sapotilla Hinds in Proc. Zool. Soc. Lond. p. 74. April, 1844. Hinds inVoy. Sulph. Moll. pl. 13. f. 10, 11. 1844. Thes. Conch. p. 383. No 39. pl. 77. f. 150-1. 1846. 
Station.-From 5 to 13 fathoms sandy mud; Hinds ! copied by Sowerby.

We found these molluses on a flat of liquid mud, a little above low water mark. On the surface of this mud they. were moving about with great vivacity while the tide was out.

Habitat.-Panama; Hinds ! copied by Sowerby.

Panama ; E. Jewett! Gould Mss.

Panama ; C. B. A. !

Mr. Hinds calls this species "the American analogue" of M. prunum Gm. (syn. M. coerulescens Lam.) but Mr. Sowerby assigns $M$. prunum to Panama as its habitat! A little east of Punama we obtained $\mathbf{4 0}$ living specimens of $M$. sapotilla, and also collected many dead shells on the beach above the muddy flats. No specimen of $M$. prunum was found. The latter, however, ocours abundantly in some parts of the Caribbean sea. We have obtained in Jamaica a large number of this species, said to have been taken on the keys south of that Island, and the Hon. Edward Chitty, of J., kindly gave us a parcel said to have heen collected at Curaçoa. Independently of the testimony, the other shells, which were mingled with these parcels, were all Caribbean, speoies. Without affirming anything respecting the existence of $M$. prunum on the west coast of Africa,* we may therefore safely say that it is the Caribbean species, -as $M$. sapotilla is the Pacific species-of tropical America.

- Mr. J. H. Redfield, the best authority in reference to this genue, informs me that be has examined many parcels of shells collected in the Gambia region, at Cape l'almas, and the I. of St. Thomas, in the Gulf of Guinea, and has never been able to find any evidence that the $M$. prinum inhabits West $\Delta$ frica $M r$. R. suggests that by some means Adanson may have been in error, and that his error han been simply copied by all subsequent authors. 
Family MITRID丑.

\section{'16. Mitra funiculata. •}

Synonymy.

Mitra funiculata Reeve Conch. Icon. pl. 16. f. 122.

Oct. 1844.

Reeve Proc. Zool. Soc. London. p. 177. Dec. 1844.

Station.-In coral sand at the depth of 14 fathoms; Curning ! Reeve.

Habitat.-I. of Plata ; Cuming ! Reeve.

I. of Plata ; Jay.

Panama; C. B. A. !

We were indebted to the hermit orabs for 23 spécimens in different stages of growth.

\section{7, Mitra lens.}

\section{Synonymy.}

Voluta lens Wood Ind. Test. Supp. pl. 3. f. 25.

1828.

Tiara foraminata (Swains. Mss.) Brod. Proc. Zool. Soc. Lond.

p. 194.
Mitra Dupontii
Kiener Iconog. p. 43. pl. 18. f. 39.

Dec. 1835.

lens Reeve Conch, Icon. pl. 1.f. 1. Aug. 1844.

Wood's figure is too wide anteriorly: Kiener's figure is both elegant and inacourate; the description is much better: Reeve's figure leaves nothing to be desired.

Station.-Sandy mud, at a depth ranging from 6 to 14 fath. oms ; Cuming! Broderip : also Reeve.

Habitat.-Unknown; Wood.

Panama, St. Elena, and I. of Plata ; Cuming ! Broderip : also Reeve.

The Red Sea ; Kiener.

Mazatlan; Melchers! Menke.

Panama, and St. Elena; Jay. 
La Paz; Major Rich! Gould Mss.

Panama; E. Jewett! Gould Mss.

Panama ; C. B. A.!

We were indebted to the hermit orabs for 24 specimens in different stages of growth.

Kiener's statement is doubtless erroneous.

\section{Mitra nucleola.}

\section{Synonymy.}

Mitra nucleola Lam. in Ann. Mus. XVII. 218. No. 64.

- Kiener Iconog. p. 84. pl. 26. f. 83. vars. excl.

- Pot. \& Mich. Gal. Moll. Mus. Douai.I. 499. pl. 35. f. 15.16.

- Lam. An. sans Vert. X. 337. No. 64. (Desh. ed.) 1844.

- Reeve Conch. Icon. pl. 28. f. $226 . \quad J a n .1845$.

We had at first some doubts of the identity of our specimens with the Lamarckian species, but the differences between their form and that of Mr. Reeve's figure are precisely similar to those between the half-grown, and the mature $M$, granulosa of the Caribbean seas. M. Kiener's remarks leave no room for doubt. Our shells, being fresh, are of a deep brown, like fresh specimens of the Caribbean species.

Station.-Unknown.

Habilat.-Unknown; Lamarok: also Potiez and Miohaud: also Reeve.

Indian Ocean, seas of Java; Kiener.

Panama ; C. B. A. !

We obtained 11 specimens, none of which are quite mature. Kiener's statement of habitat is probably incorrect.

Kiener remarks that this shell is only a variety of Mitra granulosa; Reeve says that there is " no analogy whatever," 
between these species. We will venture to add that while the species are clearly distinct, they constitute one of those interesting pairs of analogues, which inhabit opposite sides of the Isthmus of tropical America.

M. granulosa we believe to be exclusively a Caribbean species, although Kiener says " Habite les mers de l'Inde et de la Nuuvelle Zélande, de la Guadeloupe, de la Trinité et du Mexique."

\section{Mitra solitaria. Nov. sp.}

Shell rather slender, fusiform: of a very deep blackish brown, less deep in the aperture, and quite pale on the plaits : with very numerous small transverse ribs, which are obsolete anteriorly, and which are granulated by revolving striæ, that are obsolete in the interspaces posteriorly, and are strongly developed anteriorly, with mioroscopio inoromental striæ; apex aoute: whorls ten, moderately convex, slightly shouldered above, with a moderately impressed suture: aperture long, with a rather short canal : labrum thick, with numerous sharp plaits inside, with a sinus near the posterior end : columella with four plaits. Length .68 inch; breadth, .23 inch; length of aperture, .34 inch.

Station.-Under stones near low water mark we found this elegant and rare shell.

Habitat.-Panama; C. B. A. !

We found a single specimen on the reef.

\section{Mitra tristis.}

\section{Synonymy.}

Mitra tristis Brod. in Proc. Zool. Soc. Lond. p. 194.

Dec. 1835. Reeve Conch. Icon. pl. 15. f. 114.

Station.-In sandy mud at the depth of 6 to 10 fathoms; Cuming! Broderip; also Reeve. We found ser. 
eral individuals alive under stones near low water mark.

Habitat.-St. Elena, and the Galiapago Islands; Cuming ! Broderip : also Reeve.

St. Elena ; Jay.

Taboga ; C. B. A. !

We obtained 28 specimens, of which 20 are immature, and only 3 are both mature and perfect.

\section{Family PURPURID $\approx$.}

TEREBRA. Although 11 species of this genus were collected, the number of specimens is small, and they are more or less imperfect. Probably they all, like most of their congeners, and as is well known of several of these species, live only below low water mark. 5 of the species may be new ; but as our specimens are not perfect and not sufficiently numerous for distribution, we shall leave them undescribed.

\section{Terebra elata.}

\section{Synonymy.}

Terebra elata Hinds in Proc. Zool. Soc. Lond. p. 156. Dec. 1843. - - Hinds in Sowb. Thes. Conch. p. 177. No. 78. pl. 45.f. 68.69. - - - - - $\quad 3844$.

Station.-In 15 fathoms, coarse sand; Hinds !

Habitat.-Bay of Montija; Hinds !

Montija ; Jay.

Panama; C. B. A.!

We obtained 4 specimens.

\section{Terebra larvaformis.}

[Synonymy.

Terebra larvaformis Hinds in Proc. Zool. Soc. Lond.

$$
\text { p. 155. - - - - Dec. } 1843 .
$$


Terebra larvaformis Hinds in Sowb. Thes. Conch. p. 176.

$$
\text { No. 73. pl. 43. f. 46. } 47 .
$$

Station.-In from 6 to 15 fathoms, sandy mud; Hinds!

Habitat.-St. Elena, Monte Christi ; Hinds!

Monte Christi ; Jay.

Panama ; C. B. A.!

We found only 2 specimens.

\section{Terebra robusta.}

\section{Synonymy.}

Terebra robusta Hinds in Proc. Zool. Soc. Lond. p. 149. Dec. 1843. - Hinds in Zool. Voy. Sulph. Moll. p. 32. Hinds in Sowb. Thes. Conch. p. 152. No. 5. pl. 42. f. 35. - - - 1844.

Station.-In from 4 to 18 fathoms, sandy mud; Hinds !

Habitat.-West coast of America, between $8^{\circ} 57^{\prime}$ and $21^{\circ} 32^{\prime}$ N. lat.; namely, at Panama, Gulf of Nicoya, Gulf of Papagayo, and San Blas; Hinds! Gulf of Nicoya; Jay. Panama; E. Jewett! Gould Mss. Panama; C. B. A.!

We collected 5 specimens.

\section{Terebra specillata. .}

Synonymi.

Terebra specillata Hinds in Proc. Zool. Soc. Lond. p. 155. Dec. 1843. Hinds in Zool. Voy. Sulph. Moll. p. 34. 1844. Hinds in Sow b. Thes. Conch. p. 163. No. 35.

$$
\text { pl. 44.f. } 96 .
$$

Station.-7 fathoms, sandy mud; Hinds !

Habitat._San Blas; Hinds!

San Blas; Jay. 
Panama; C. B. A.!

We collected 12 specimens in various degrees of preservation:

\section{Terebra tuberculosa.}

Synonymy.

Terebra tuberculosa Hinds in Proc. Zool. Soc. Lond. p. 154. Dec. 1843.

- - Hinds in Zool. Voy. Sulph. Moll. p. 34. 1844.

— Hinds in Sowb. Thes. Conch. p. 175. No. 72. pl. 43. f. 48 .

1844.

Slation.-From 4 to 11 fathoms; Hinds!

Habitat.-Panama, Gulf of Papagayo, and San Blas; Hinds ! Panama; C. B. A.!

Only 1 specimen was found.

\section{Terebra varicosa.}

Synonymy.

Terebra varicosa Hinds in Proc. Zool. Soc. Lond. p. 152.- Dec. 1843. - - Hinds in Zool. Voy. Sulph. Moll. p. 32. 1844. - Hinds in Sowb. Thes. Conch. p. 163. No. 37. fig. on same page. :

Station.-23 fathoms, mud:; Hinds!

Habitat.-Gulf of Papagayo Hinds! Panama; C. B. A !

We obtained only 1 specimen.

27. Tercbra (a).-Like $T$. specillata, but more finely soulptured: 2 specimens.

28. Terebra (b). -A slender brown species: 5 specimens.

29. Terebra $(c)$.- Small, olivaceous, with a dingy white band next above the suture: 1 specimen.

30. Terebra (d).-A small very delicately and sculptured shell : 1 specimen.

31. Terebra $(e)$. -1 very imperfect specimen. 
OLIVA: In searching for species of this genus, I had but little success, although all the sands near Panama were visited, from the low water mark of the spring tides upwards. Of the ten species which were obtained, only one was found alive. Probably the species appear chiefly at certain seasons. The one which was found alive in countless myriads, was seen during only a part of my stay in Panama.

\section{Oliva angulata.}

\section{Synonymy.}

Davila Catal. I. pl. 15. f. F. - - 1767. Martini Conch. Cab. II. 164. pl. 47. f. 499.500 . 1773.

Schrot. Einl. Conch. I. $248 . \quad-\quad 1783$.

Voluta oliva var. F Gmel, in Linn. Syst. Nat. p. 3440. - 1788. Oliva angulala Jum. in Ann. Mus. XVI. 310. No. 0. 1810. Voluta incrassata Dillw. Catal. I. 516. No.35. - - 1817. - Wood Ind. Test. pl. 19. f. 35. - 1818. Oliva angulata Lam. An. sans Vert. VII. 420. No. 6.

Aug. 1822.

Encye. Meth. pl. 363. f. 6.

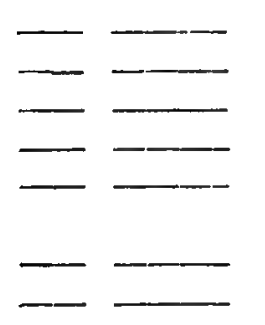
Desh. in Encye. Meth. Vers. III. 649. No. 9. 1832. Ducl. Mon. Oliva. pl. 17. f. 9. 10. 1835. Küst. Conch. Cab. pl. 2. f. 1.2. - $\quad 1840$. Ducl. in Chenu. pl. 18. f. 9. 10. Lam. An. sans Vert. X. 607. No. 6. 1843.

Desh. Ed. 1844. Reeve Elem. Conch. pl. 1. f. 4. also pl. D. 1846. Reere Conch. Icon. pl. 1. f. 1. Optimè. Nov. 1850.

Station.-In sandy mud, at the depth of 9 fathoms; Cuming! Reeve.

Habitat.-Unknown; Wood : Lamarck.

Peru; Deshayes.

Gulf of Nicoya, Central America; Cuming ! Reeve : also Duclos. 
Bay of Magdalena; Duolos.

Muzatian; Melohers! Menke.

Real Lulejos; Jay.

Bay of Panama ; C. B. A.!

The text of Duclos (in Chenu Ill. Conch.) is somewhat ambiguous; "Habite la baie de la Madeleine, le golfe de Nicoyo, Costa Rica, Amérique oentrale, d'oł M. Cuming l'a rapportie." The Bay of Magdalena is much farther north than Costa Rica, on the outside of the peninsula of California in latitude $24^{\circ} 30^{\prime} \mathrm{N}$. Probably a different punctuation should have been used, so as to indicate two distinct localities.

We obtained 17 fine large specimens in the fruit shanty before mentioned. They were said to have been taken "down the bay." Their condition, and the other shells which were with them, fully confirmed the statement.

\section{Oliva araneosa.}

\section{Synonymy.}

Martini Conch. Cab. II. 167. pl. 48. f. 509. 510. 1773. Oliva araneosa Lam. in Ann. Mus. XVI. 315. No. 19. 1810 . —_ —_ Lam. An. sans Vert. VII. 424. No. 19. Aug. 1822. Lam. in Encyc. Meth. pl. 363. f. 1. 1824. Lam. An. sans Vert. X. 614. No. 19. Desh. Ed. 1844. reticularis lieeve Conch. Icon. pl. 10. f. 16g. 16d. alt. excl. Aug. 1850.

If Lamarck and Duclos have sometimes gone into the one extreme of excessive multiplication of species, Mr. Reeve has, we fear, in a rare instance of error, gone to the opposite extreme, in uniting with $O$. reticularis, $O$ araneosa, and $O$. venulata of Lam., and Duclos' species O. Timoria, O.obesina, and $O$. pindarina. Mr. Reeve's fig. 16a. represents well the common Caribbean species, O. reticularis, which inhabits the islands and main land around the Caribbean sea. Fig. $16 i$ 
resembles a variety of the same species, which Mr. Redfield has received from Carthagena. But figs. $16 d$ and $16 \mathrm{~g}$ represent the kindred type of the Pacific shore. This we suppose to be $O$. araneosa of Lamarck. The differonce between the Caribbean and the Pacific types is somewhat less in value than the average difference between species. But we have elsewhere shown, (Cont. Conch. p. 191,) that it is impossible to make all the species of exactly equal value. Those figures on Mr. Reeve's pl. X, which we have not before referred to in this paragraph, represent probably one or two other species of the Pacific coast.

In consequence of this union of distinct types, $\mathrm{Mr}$. R. gives as the habitat of O. reticularis, "Gulf of California : Donnet. I. of Granada, West_Indies ; J. Cuming."

Station.-Unlinown.

Habilat.-South Seas? Lamarck.

Bay of Panama; C. B. A.!

In the fruit shanty we found 1 specimen, in company with other shells, all of which had been taken near Panama.

\section{Oliva inconspicua. Nov, sp.}

Shell rather slender: white: smooth: spire about as long as the aperture : apex rather obtuse: whorls six, with a well impressed suture, slightly convex : aperture acuminate in the upper half, subrectangular in the lower half: labrum thin: anterior notch very slight, wide.

Mean divergence about $30^{\circ}$; in another specirnen nearly $40^{\circ}$; length .15 inch; breadth .055 inch.

Station.-Unknown.

Habitat.-Panama; C. B. A.!

We obtained only 3 mature specimens and one immature, in picking over several quarts of fine drift materials gathered on the shore near the city wall. 
A kindred undescribed species ocours in Jamaica. Like the above and like most of the minute rare tropical species, it appears to have escaped the notice of collectors.

\section{Oliva pellucida.}

Synonymy.

Oliva pellucida Reeve Conch. Icon. pl. 27. f. 85. - Nov. 1850. Stäion.-Unknown.

Habitat.-Unknown; Reeve. Panama; C. B. A. !

We obtained one specimen, which is about three-fifths as large as Mr. Reeve's specimen.

\section{Oliva porphyria.}

Synonymy.

Gualt. Test. pl. 24. f. P. - 1742. D'Argenv. Conch. p. 285. pl. 16. f. K. 1742. D'A rgenv. Conch. p. 243. pl. 13. f. K. 1757. Knorr. Vergn. I. pl. 15. f. I. - 1757.

Voluta porphyria Linn. Syst. Nat. (Ed. 10.) I. 729. No. 349. 1758.

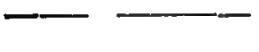

Linn. Syst. Nat. (Ed. 10. alt.) I. Pars. II. p. 1187. No. 338 . - - 1767. D'Argenv. Conch. p. 201. pl. 13. f. K. 1772. Martini Conch. Cab. II. 157. pl. 47. f. 485-6. pl. 47. f. 498.

Panama or Camp Olive Da Costa Elem. Conch. pp. 189. 291. pl. 5. f. 4. 1776.

Favanne's D'Argenv. II. 818-822. pl. 19. f. K. 1780.

Voluta porphyria

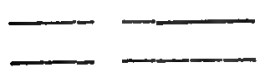

Oliva
Born Mus. Cæs. p. 212.

Schröt. Einl. I. 201. No. 7.

Gmel. in Linn. Syst. Nat. p. 3438. No. 16.

Lam. Syst. An. sans Vert. p. 76.
1780 . 1783. 1788. 1801. 


\section{Oliva porphyria}

Voluta

Oliva

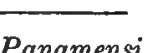

- Panamensis

- porphyracea

Voluta porphyria
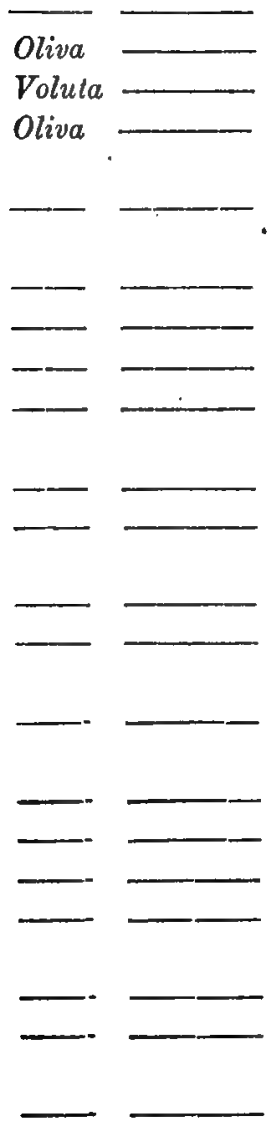

Cubieres' Hist. Coq. p. 69. pl. 7. f. 4 .

Roissy in Buff. Moll. V. 429. No. 1.

pl. 56.f. 6. - - - - 1803.

Turt. in Linn. Syst. Nat. IV. 301.1806.

Lam. in Ann. Mus. XVI. 309. No. 1. 1810. seu porphyrius Montf. Conch. Syst. II. 387. f. ad p. 386.

1810.

Perry Conch. pl. 41. f. 3. - Jan. 1811.

Brooke Introd. Conch. pl. 6. f. $68 . \quad 1815$.

Dillw. Catal. 1. 510. No. $29 . \quad 1,817$.

Schum. Nouv. Syst. p. 243. - 1817.

Wood Ind. Test. pl. 19. f. $29 . \quad$ - $\quad 1818$.

Lam. An. sans Vert. VII. 418.

No. 1. - - Aug. 1822.

Children's Lam. Gen. pl. 5. vol. 16. f. 209. 1823.

Sowb. Gen. pl.-. f. $1 . \quad-1824$.

Lam. in Encyc. Moth. pl, 361. f. 4. 1824. Blainv, Malnc. pl. 30. f. $4 . \quad$ - 1825. lioux Icon. Conch. Liv. I. p. 4. pl. 3.

f. 6.

1828.

Stark Elem. Nat. Hist. I. $25 . \quad$ - $\quad 1828$.

Desh. in Encyç. Meth. Vers. III. 648.

No. 8.

1832.

Ducl. Monog. Oliva. pl. 24. f. 1-5. 1835.

Pot. et Mich. Gal. Moll. Mus. Douai.

I. 471 .

1838.

Küst. Conch. Cab. p. 10. pl. 2. f. 5. pl. 6. f. 1. 2.

1840.

Reeve Conch. Syst. pl. 273. f. 1. 1842.

IIanley Conch. Book Spec. p. 130.1842.

Ducl. in Chenu Ill. Conch. pl. 1.f. 1-5. 1843.

Lam. An. sans Vert. X. 605. No. 1.

Desh. ed.

1844.

Reeve. Conch. Icon. pl. 1. f. 2. Nov. 1850.

Heck Icon. Encyc. pl. 75. f. 125.

Baird ed. - $\quad$ - 1851.

Woodward Man. Moll. p. 116. pl. 6.

f. 16.

1851.

Slation.-In sandy mud at low water; Cuming! Reeve. 
Itabilat.-Unknown; Linnous, 1758.

Brazil ; Linnæus, 1767 : also Gmelin : also Turton : also Say in Catal. of his Mus.

West Indies and cnasts of South America; Dillwyn. West Indies; Wood.

Seas of South America ; shnres of Brazil ; Larnarck : also Roux : also Potiez and Michaud: also Kïster.

"L'Olive de Panama;" Lamarck : also Blainville. South America; Ravenel in Catalogue.

Panama; Cuming ! Reeve.

Punama; Jay : also Woodward.

Mazatlau; Melchers! Menke.

La Paz, Lower California ; Lt. Green! Gould Mss. Bay of Panama; C. B. A. !

Linnæus, Dillwyn, Wood, and Lamarck are obviously in an error, which has been successively crpied from the former. But the common name of the species, which we find in most of the old authors, indicates the true habitat.

Unfortunately none of my rambles were rewarded with a epecimen in any condition. 'Two or three were seen in the fruit shanty among other shells, all of which inhabit the vicinity of Panamx.

Two intensily colored specimens in the Mus. Amh., from an unknown habitat, are $\frac{3}{4} \mathrm{in}$. long and $2 \mathrm{in}$. wide.

\section{Oliva semistriata.}

\section{Synonymy.}

Oliva semistriata Gray, Zool. Beech. Voy. pl. 36. f. 10. 1839.

- $\longrightarrow$ Siebold, Wiegm. Archiv. 1. 210. Oct. 1850.

Station.- "Moving about by hundreds, with great rapidity, in the wet sand ;" Curning ! Reeve. 
Habitat.-Salango, West Columbia ; Cuming ! Reeve. Panama; C. B. A. !

We obtained a few specimens, which were ocoupied by hermit crabs, on the reef at Panama, near low water mark. In the fruit shanty we purchased 175 specimens, which appeared to have been taken alive.

\section{Oliva testacea.}

Synonymy.

Oliva testacea Lam. in Ann. Mus. XVI. 324. No.51. - 1810.

- - Lam. An. sans Vert. VII. 435. No.51. Aug. 1822.

- - Valen. in Humb. Rec. Obs. II. 334. - 1833.

- - Duclos in Chenu Conch. Ill. pl. 3. f. 17. 18. (f. 19. 20. excil.)

1843.

- - Lam. An. sans Vert. X. 627. No. 51. Desh. Ed. 1844.

_- _ Reeve Conch. Icon. pl. 18. f. 36. Sept. 1850.

Station.-In sandy mud at a depth of about 6 fathoms; $\mathrm{Cu}$ ming! Reeve.

Habilat.-The South Sea, on the shores of Mexico; Humboldt and Bonpland! Lamarck.

Acapulco; Humboldt and Bonpland ! Valenciennes.

Mexico and California; Duclos.

Mazatlan; Melchers! Menke.

Panama; Jay.

Real Llejos, Mexico; Cuming! Reeve.

Panama; C. B. A.!

Duclos says, "Habite le Mexique pour sa plus grande taille, la Californie pour sa plus petite, et la Nouvelle Hollande pour la varieté blanche." The variety (f. 19.20.) is evidently a distinct species.-Mr. Reeve's punctuation seems to imply that Real Llejos is in Mexico, but since Real Llejos is not in Mexico, the latter must be another habitat on the authority of Mr. Cuming, unless Mr. R. has fallen into a geographical error. 
On the sand beach, next west of Panama, we collected 20 dead but entire specimens.

\section{Oliva undatella.}

Synonymy.

Oliva undalella Lam. in Ann. Mus. XVI. 326. No. 55.

1810.

—— Lam. An. sans Vert. VII. 438. No. 58. Aug. 1822.

—— tenebrosa Wood. Ind. Test. Supp. pl. 4. f. $38 . \quad$ - 1828.

—- undatella Ducl. Mon. Oliva. pl. 5. f. 5-10. 1835.

- —— Gray, Zool. Beech. Voy. pl. 36. f. 23, 27. 1839.

-- Duclos in Chenu Ill. Conch. pl. 6. f. 5-10. 1843.

- Lam. An. sans Vert. X. 630. No. 58.

- Reevo Conch. Icon. pl. 25. f. 73. - Oct. 1850.

Wood's accurate figure appears to have been overlooked by most authors.

Station.-In sand and on mud banks at low water; Cuming! Reeve.

Habitat._Unknown; Wood.

Acapulco; Humboldt and Bonpland! Lamarck:

Duclos.

West coast of Mexico; Say in Catal. Mus.

Pacific; Ravenel in Catalogue.

Mazatlan; Melchers! Menke.

Acapulco; Jay.

Bay of Panama; Cuming! Reeve.

Panama ; E. Jewett! Gould Mss.

Panama; C. B. A. !

For this species I was indebted wholly to the hermit crabs. 15 specimens were obtained near a sandy spot on the reeî, near low water mark. They are all of one pattern of coloring intermediate between Wood's figure and $73 b$ of Reeve. 


\section{Oliva venulata.}

\section{Synonymy.}

Doluta ispidula var. $\beta$ (pars) Born. Mus. p. 216.

1780.

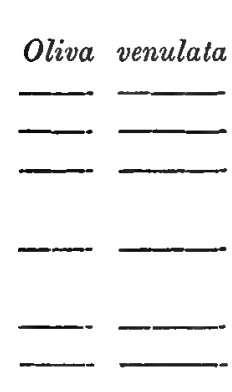

Martini Conch. II. 158. pl.46. C. 488.1773.

Lam. in Ann. Mus. XVI. 313. No. 13.1810.

Lam. An. sans Vert. VII. 422. No. 13. Aug. 1822.

Lam. in Encyc. Meth. pl. 361. f. 5.

1824.

Desh. in Encyc. Metl. vers. III. 650.

No. 12.

1832.

Pot. et Mich. Gal. Moll. Mus. Douai. I. 472.

1838.

Küst. Conch. Cab. pl. 6. f. 5. - 1840.

Lam. An. sans Vert. X. 611. No. 13.

Desh. Ed.

1854.

-_- reticularis var. Reeve Conch. Icon. pl. 10. f. $16 b$. (alt.

excl.) - - - Aug. 1850.

Our specimen more resembles O. splendidula as figured in the III. Conch. of Chenu, than O. venulata in the same work. We think, however, that it is the species, which is figured in the Encyc. and by Reeve as above. The principal difference between this shell and O. araneosa is in the short dark brown bent lines of the former.

Station.-Unknown.

Habilat.-Unknown; Lamarck : also Potiez and Michaud.

Mazatlan; Melchers! Menke.

La Paz; Lt. Green! Grould Mss.

Bay of Panama; C. B. A. !

Duclos (in Chenu) says of his $O$. venulata, which probabiy belongs to a different species from ours, "Habite la mer des Indes." In the fruit shanty we found 1 specimen among other shells, all of which are known to inhabit the Bay of Panama. 
OLIVA.

\section{Oliva volutella.}

Synonymy.

Oliva volutella Lam. in Ann. Mus. XVI. 322. No. 43. - 1810.

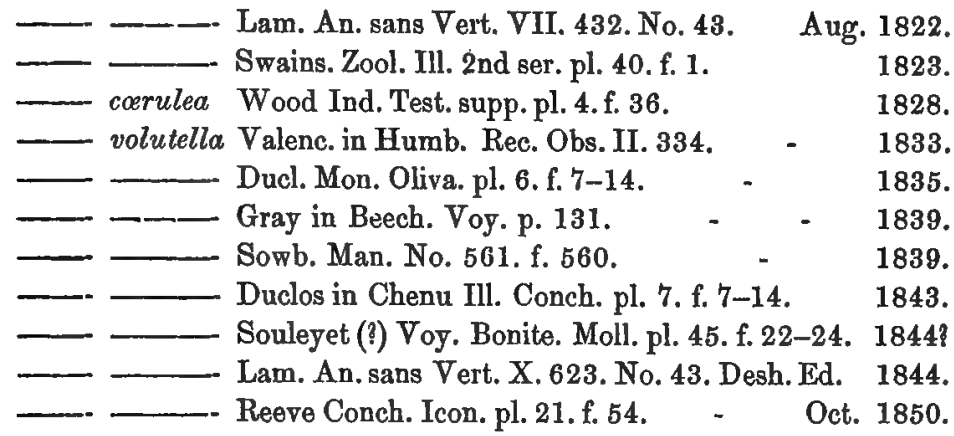

Slation.-On mud banks at low water; Cuming! Reeve.

This species we found alive in vast numbers, over an extent of many acres, on the sand beach west of the city of $\mathrm{Pa}$ nama. They were most numerous where the beach had a gentle slope, about midway between high and low water mark. Some time after the retreat of the tide they were found. crawling about with much vivacity on the wet sand. The shell, while the animal was moving, was wholly covered with the mantle, and the mantle was entirely concealed with a thick coat of sand. When the first wave of the returning tide struck them, washing off their coats of sand, they instantly buried themselves. Frequently, however, I passed over this spot without seeing any of them. They were also found, but in less numbers, just above the low water mark of the neap tides, on sandy flats near the beach above mentioned.

Habitat.-Shores of Mexico ; Humboldt and Bonpland! Lamarck.

Isthmus ; Swainson.

Unknown; Wood. 
Acapulco; Humboldt and Bonpland! Valenciennes. West coast of Mexico; Say in Catal. Mus. Mexico, California, Panama; Duolos.

Panama; Cuming! Reeves also Möroh.

Panama; Jay.

Panama; C. B. A.!

We collected 4,500 specimens.

\section{Planaxis plamicostata.}

\section{Synonymy.}

Planaxis planicostata Sowb. in Tank. Catal. No. 1418. App. p.18. 1825. Buccinum planaxis Wood Ind. Test. Supp. pl. 4. f. 15. Planaxis canaliculata Duval in Rev. Zool. 1828. Apr. 1840 . Trosch. in Wiegm. Archiv. p. 271. planicostata Reeve Elem. Conch. pl. B. f. 17. 1846.

The epidermis of this shell is exceedingly thick and tenacious, and of a dingy olive green. Beneath the epidermis the shell is black, but near the apex and in faded specimens the color is brown. All the specimens at Panama and in one spot at Taboga belong to a large variety, and are often more than an inch long. The others at Taboga were mostly from .6 inch to .7 inch long.

Station,-Under stones between high water and half tide level.

Habitat.-Gallapago Is.; Sowerby: also Duval : also Jay.

Panama; E. Jewett! Gould Mss.

Taboga and Panama; C. B. A. !

At Taboga in incredible numbers: less common on the reef at Panama. We collected about 1200 specimens. 
NASSA. Mr. Powis has desoribed in the Proceedings of the Zoological Society of London, 1835, pp. 95, 96, seven speoies of this genus from Panama and from other parts of the same Zoological province. We obtained fourteen species, two (perhaps three) of which answer to the descriptions by Mr. Powis.

43. Nassa canescens. Nov. sp.

Shell rather long, ovate conic: pale brown on all the raised portions of the surface, with the interspaces pale gray : with ten or eleven very prominent narrow ribs, and many raised spiral lines, which are not interrupted by the ribs, and of which two on the middle of the whorls and some anteriorly. are larger: spire with the outlines nearly rectilinear: apex aoute : whorls eight or nine, subangular in the middle, with a well impressed suture; last whorl moderately ventricose, anteriorly spirally subcanaliculate : aperture subelliptioal : labrum subacute, much thickened by a varix a little behind the edge, finely grooved within: labium finely wrinkled, a little dilated but not appressed : notch large and deep.

Mean divergenoe about $50^{\circ}$; length 1.05 inoh ; broadth .6 inch; length of spire .6 inch.

Station.-Unknown. :

-Habitat.-Panama ; C. B. A !

1 specimen was obtained.

\section{Nassa collaria. Nor. sp.}

\section{Synonymy.}

Nassa collaria, Gould MSS.

Shell ovate conio: dingy white, with a dark reddish brown band on each side of the whorl: with, on each whorl, about ten or twelve ribs, which are smaller and more approxi- 
mate but not obsolete on the last part of the last whorl; with many spiral raised lines, with the intersections subnodulous: spire with the outlines nearly rectilinear : apex acute: whorls seven, slightly convex, with a distinct suture; last whorl with a minute spiral canal anteriorly: aperture subelliptical : labrum subacute, thickened with a stout varix, within crenulated coarsely and unequally: labium a little thickened, not appressed : with a deep notch.

Mean divergence about $50^{\circ}$; length .38 inch: breadth .21 inch; length of spire .23 inch.

Var. $\alpha$; smaller (.23 inch long); with the lower fasoia much broader, and darker anteriorly.

Station.-Unknown.

Habitat.-Panama ; (var. $\alpha$ ) ; E. Jewett! Gould Mss.

Panama; C. B. A.!

We obtained 4 specimens of the type, and one of the variety.

\section{Tassa corpulenta, Nov. sp.}

Shell ovate conic, very robust: spirally banded with white and brown, sometimes mostly white, sometimes mostly brown, with a broad white stripe below the middle of the last whorl, white in and about the aperture: with, on each whorl, about eleven narrow ribs, which are traversed by spiral raised lines: spire with the outlines rectilinear or slightly concave : apex acute: whorls nine, moderately convex, with a well impressed suture; last whorl very large and ventricose, spirally canaliculate anteriorly : aperture subelliptical, contracted : labrum subacute thickened with a very stout varix, within coarsely sulcate: labium wrinkled, a little thickened but not appressed: notch large and deep. N. festiva Powis must resemble this shell, and possibly may be identical with it.

Mean divergence about $46^{\circ}$; length .88 inch; breadth .63 inch; length of spire .46 inch. 
NASSA.

Station.-Unknown.

Habitat.-Panama; E. Jewett ! Gould Mss. Taboga and Panama; C. B. A.!

17 specimens were obtained.

\section{Nassa gemmulosa.-Nov, sp.}

Shell ovate conic, ventricose : whitish, more or less tinged with yellowish brown; with a narrow spiral stripe of brown at the upper margin of the whorls, and another anteriorly; with two or three minute spiral brown lines on the middle of the last whorl, which are interrupted by the nodules: with about fifteen or sixteen minute ribs on each whorl, and spiral raised lines, of which three or four are visible on the spire; with the intersections developed into well rounded nodules: spire with the outlines rectilinear: apex very acute: whorls seven, a little convex, with a distinct suture; last whorl spirally subcanaliculate anteriorly : labrum subacute, well thickened by a varix, coarsely ridged within: labium much arcuated, a little thickened but not appressed : notch deep.

Mean divergence about $56^{\circ}$; length .25 inch ; breadth .17 inch; length of spire .15 inch.

Station.-Unknown.

Habitat.-Panama ; C. B. A.!

1 specimen was obtained.

\section{Nassa glauca.-Nov. sp.}

Shell ovate conic, ventricose: glaucous or olivaceous, with a broad spiral stripe of dingy white a little above the suture, whitish about the aperture, deeply colored in the anterior spiral canal: with, on each whorl, about ten ribs, of which the last two or three next to the aperture are nearly obsolete; with many spiral striæ, which traverse the ribs: spire with the outlines nearly rectilinear: apex acute: whorls eight, 
moderately convex, with a distinct suture ; last whorl ventricose, with a narrow deep spiral canal anteriorly: aperture subelliptical: labrum subacute, thickened with a stout varix, within with about five aoute spiral ridges: labium well thickened, not appressed : notch deep.

Mean divergence about $55^{\circ}$; length .5 inch; breadth .31 inch; length of spire .28 inch.

Var. $\infty$; with the color nearly black.

Station.-Unknown.

Habitat.-Taboga ; C. B. A. !

32 specimens were collected.

\section{Nassa Iuteostoma.}

\section{Synonymy.}

Nassa luteostoma Brod. \& Sowb. in Zool. Journ. IV. 370. 1829. Buccinum Kiener Iconog. p. 110. pl. 30. f. 1. Nassa xanthostoma Gray in Zool. Beech. Voy. pl. 36. f. 3. (parva.) 1839. Souleyet (?) Voy. Bonite. Moll. pl. 41.

f. 5-7. -1844 ?

- luteostoma Reeve Elem. Conch. pl. 3. f. 11. 1846. xanthostoma Mrs. Gray Moll.pl. 85a. f. 5. (soft parts.) 1850.

Station.-On sand, usually not far below high water mark, in places where water is running during the recess of the tide: also in similar places not far above low water mark.

Habitat.-Senegal; Kiener : also Jay.

Real Llojos, and Acapulco; Lesson.

Mazatlan; Melchers! Menke.

Panama; E. Jewett! Gould Mss.

Panama ; C. B. A. !

We collected 330 specimens, mostly near the sea wall of Panama. "M. Kiener indique le Senegal pour patrie a cette 
coquille; il y a, sans donte, erreur." Lesson in Rev. Zool. Aug. 1842.

\section{Nassa nodifera.}

Synonymy.

Nassa nodifera Powis in Proc. Zool. Soc. Lond. p. 95. June. 1835.

This shell has distant fine spiral striæ, which are usually obsolete on the middle of the whorls. Some specimens are ornamented with spiral lines of dark brown, and rarely the whole shell, except the aperture, is dark brown. Mr. Powis disposes of the coloration with the single word albescente, but otherwise his brief description corresponds exactly with our shells.

Siation.-In coral sand, in from 6 to 10 fathoms; Cuming ! Powis.

Habitat.-Gallapago Islands and the shores of Panama; Cuming! Powis.

Taboga; C. B. A.! ;

40 specimens were collected.

\section{Nassa pagodus.}

\section{Synonymy.}

Buccinum decussatum Kiener (nec Linn. nec Lam.) p. 109. No. 108. pl. 30. f. 3.

Triton pagodus Reeve in Proc. Zool. Soc. Ldpd. p. 121. July. 1844. Reeve Conch. Icon. pl. 20. f. 97. Aug. 1844.

The colors are sometimes more intense than in Mr. Reeve's figure. From M. Petit we have received two speoimens labelled $B$. decussatum Kiener; Payta.

Station.-Unknown. 
Habitat.-Atlantio Ocean, on the shores of Africa; Kiener. "Bay of Montija, West Columbia;" Cuming! Reeve.

Payta; Petit in sched.

T'aboga and Panama ; C. B. A. !

22 specimens were collected.

51. Nassa Pamamensis.-Nov. sp.

Shell long ovate conic: bluish olivaceous, with a whitish spiral line below the middle of the whorls; colors more dis. tinot on the ribs; whitish near the upper part of the labrum; anteriorly with a pale spiral band, which is sometimes obsolete: with, on each whorl, about eleven narrow acute ribs, which are obsolete anteriorly; with very minute spiral striæ, which are less distinct below the middle of the whorls : spire with the outlines moderately curvilinear : apex acute: whorls eight, slightly convex, with a distinot suture; last whorl not ventricose: aperture elliptical; labrum thickened by a stout varix: labium thickened but not appressed : notch deep.

Mean divergence about $37^{\circ}$; length .58 inch; breadth .25 inch; length of spire .35 inch

Station.-Under stones, a little above low water mark, in company with several species of Columbella.

Habitat.-Panama ; C. B. A.!

We collected about 1500 specimens on the reef.

52. Nassa proxima.-Nov. sp.

(Shell like that of $N$. versicolor (v. infrà), but much more slender, with the ribs less prominent, and very densely covered with very minute uninterrupted striæ, which give a silky lustre to the surface.

Mean divergence about $38^{\circ}$; length .44 inch; breadth .21 inch.; length of spire .28 inch. 
NASSA.

Station.-Unknown.

Habitat.-Taboga ; C. B. A. !

One specimen was obtained.

\section{Nassa seabriuscula?}

\section{Synonymy.}

Nassa scabriuscula Powis in Proc. Zool. Soc. Lond. p. 96. June. 1835.

Our specimens are mostly pale olivaceous or glaucous, with the granules, upper part of the labrum, and a spiral stripe, of a dingy white. Mr. Powis describes his shell as fusca luteo fasciata.

Var. $a$ is deeply tinged with black, and has some pure white spots at the upper part of the labrum.

Var. $b$ is black, more gibbous, and is wholly covered with granules.

Station.-Sandy mud at a depth of 12 fathoms; Cuming ! Powis.

Our specimens were found on sand, usually not far below high water mark, where water runs during the recess of the tide; also in similar situations near low water mark.

Habitat.-Bay of Montija ; Cuming! Powis.

Panama ; E. Jewett! Gould Mss.

Panama ; C. B. A.!

We collected 380 specimens.

\section{Nassa striata.-Nov. sp.}

Shell long ovate conic: white about the aperture, otherwise dingy white more or less tinged with yellowish brown: with, on each whorl, twelve or thirteen small ribs, and many coarse spiral striæ: spire with the outlines a little curvilinear : apex acute: whorls eight, convex, with a well impressed su- 
ture; last whorl spirally canaliculate on the left side : aperture subelliptical : labrum rather sharp, thickened by a broad varix, coarsely grooved within: labium well thickened, not appressed, with two small wrinkles anteriorly: notch deep.

It resembles $N$. versicolor (v. infrà) var. striatula: but besides being more coarsely striated and minutely ribbed, the whorls are much more convex.

Mean divergence about $48^{\circ}$; length .58 inch; breadth .31 inch; length of spire .33 inch.

Station.-Unknown.

Habitat.-Taboga ; C. B. A.!

2 specimens were obtained.

55. Nassa versicolor.-Nov. sp. $d$

Shell long ovate conic: pale yellowish brown, or nearly white, with a darker sutural line, or blackish brown: some. times the ends or the summits of the ribs are whiter than the interspaces; sometimes the sutural fascia covers the anterior part of the last whorl : with, on each whorl, nine or ten narrow very prominent ribs; with very minute spiral striæ, which are nearly obsolete on the middle of the whorls; spire with the outlines nearly or quite rectilinear : apex acute : whorls eight, slightly convex, with a well impressed suture; last whorl spirally canaliculate anteriorly: aperture subelliptical: labrum subacute, thickened with a stout varix : labium thickened, not appressed, finely wrinkled : notch deep. Var. striatula is covered with very distinct strio.

Mean divergence about $45^{\circ}$; length .6 inch; breadth .33 inch; length of spire .35 inch.

$N$. ambigua, the Caribbean analogue, is also an extremely variable species.

Station.-Unknown. 
Habitat.-Taboga ; C. B. A.!

More than 500 specimens were collected, all occupied by hermit orabs.

\section{Nassa Wilsomi.-Nov. sp.}

Shell ovate conic, ventricose : blackish brown, with a dingy white spiral band, at or a little above the suture: with sixteen to twenty small ribs, some of the last of which are obso. lete on the convexity of the whorl, and of which one next behind the varix is larger; with many spiral raised lines, which are smaller on the summits of the ribs, and which are nearly obsolete in the region where the ribs are obsolete: spire with the outlines curvilinear : apex aoute: whorls seven, slightly convex, with a distinot suture: last whorl ventricose, anteriorly with a small spiral canal : aperture suborbicular : labrum subacute, much thickened within and without, with a few sharp ridges within : labium thickened, not appressed : notch deep.

Mean divergence about $58^{\circ}$; length .32 inch; breadth .19 inch; length of spire .18 inch.

This pretty little speoies is named in honor of Dr. Thomas B. Wilson, of Philadelphia, the munificent patron and successful cultivator of Natural History.

Station.-Unknown.

Habitat.-Panama; C. B. A. !

5 speoimens were obtained.

\section{Buccinum crassum.}

\section{Synonymy.}

Phos crassus Hinds Voy. Sulph. Moll. p. 38. pl. 10. f. 1, 2. 1844. A. Ad. Ann, and Mag. Nat. Hist. VIII. No. 43. p. 71

July 1851. 
Station.-Dredged as solitary shells in from 3 to 14 fathoms among mud; Hinds!

Habitat.-Panama, and Gulf of Fonseca; Hinds !

Panama; Jay.

Panama; C. B. A.!

…. We obtained only 1 dead specimen.

\section{Buccinum distortum.}

Synonymy.

Buccinum distortum Bligh Catal. No.64. (not described.) May 1822.

- Wood Ind. Test. Supp. pl. 4. f. 7. 1828.

- - Kiener Iconog. p. 43. pl. 18. f. 64, 65.

Pollia distorta Gray in Zool. Beech. Voy. p. 112. 1839. Columbella triumphalis Ducl. in Chenu. Ill. Conch. pl. 5. f. 13-16. 1843. Buccinum distortum Desh. in Lam. An. sans Vert. X. p. 192. No. 70.

- Reeve Conch. Icon. pl. 11. f. 86. Dec. 1846.

Kiener has figured as the young of this species, f. 65, a variety in which the revolution of the whorls is more oblique, and which, when full grown, has the last whorl only moderately shouldered, like the young of the common type. We obtained only two specimens of this variety. Deshayes has well described the varying characters of this remarkable species.

The epidermis is thick, rather coarse and brown, and entirely conceals the color of the shell.

Station.-We found this species in the orevices of rocks, between the low water mark of the neap tides and that of the spring tides.

Habitat.-Unknown; Wood.

New Holland; Kiener.

Chili ; Deshayes : also Jay.

St. Elena; Cuming! Reeve. 
Buccirum.

Panama ; E. Jewett! Gould Mss.

Panama, and Taboga ; C. B. A. !

We collected 95 specimens, mostly on the reel.-Kiener's statement is undoubtedly erroneous: nor are we informed on what evidence Chili is said to be a habitat. Valparaiso being the great centre of commeroe on the west coast of South America, there is much danger of referring to that habitat species which belong to other parts of the coast.

\section{Buccinum insigne.}

\section{Synonymy.}

Buccinum mutabile Val. (non Linn.) Voy. Venus. Moll. pl. 6. f. 2. 1846. insignis Reeve Conch. Icon. pl. 8. f. 58. Dec. 1846. Station.-In clefts of rocks at low water; Cuming! Reeve. We found the species in the same situation, but more frequently under stones, and especially under stones which were lying on sand.

Habilat.-St. Elena; Cuming! Reeve.

West Columbia; Jay.

Lower California; Major Rich! Gould Mss.

Panama; C. B. A.!

We collected 140 specimens of this beautiful species on the reef at Panama. Most of them are both more completely and more intensely colored than the figure given by $\mathrm{Mr}$. Reeve. The colors are wholly concealed by a thick brown epidermis.

60. Buccimum Iugubre.-Nov. sp.

Shell long ovate-fusiform: very dark brown with a cinereous tinge: with small ribs, from nine to thirteen on each whorl, traversed by rather coarse unequal spiral striæ, with the intersections of the larger strim rather acutely nodulous : apex acute: spire conio: whorls eight, very convex, with a 
moderately impressed suture : aperture ovate: labrum rather sharp, thickened behind: with a short reourved canal.

Mean divergence about $44^{\circ}$; length .67 inch; breadth .31 inch; length of spire .4 inoh.

After much doubt respecting the generic characters of this species, we have provisionally referred it to that group of Buocina, which have a short recurved canal.

Station.-Under stones at low water mark.

Mabitat.-Panama, and Taboga ; C. B. A.!

.. We collected 175 speoimens.

\section{Buccinum pagodus.}

Synonymy.

Buccinum pagodus Reeve Conch. Icon. pl. 7. f. 50.

Dec. 1846.

Station.-In the clefts of rooks at low water; Cuming ! Reeve. We found this species in the same station and also under stones.

Habitat.-I. of Taboga; Cuming ! Reeve.

Panama; Jay.

Panama; E. Jewett! Gould Mss.

Taboga and Panama; C. B. A.!

This species is rare. Mr. Cuming obtained only one or two specimens. We obtained 7 adult, and 11 young specimens. The color of the young is very intense, almost black : that of some of the adult shells is very dark.

\section{Buccinum pristis.}

Synonymy.

Buccinum serratum Kiener Iconog. p. 23. pl. 9. f. 28.

- Reeve Conch. Syst. pl. 268. f. 5, 6.

1842 .

pristis Desh. in Lam. An. sans Vert. X. 192. No.69. 1844.

Reeve Conch. Icon. pl. 6. f. 39.

Dec. 1846. 
BUCOINUM.

Panama Shells.

The name originally given to this species by Kiener had been preocoupied by Brocohi in 1814 for a fossil species.

Station.-Probably below extreme low water mark. Our specimens were collected at low water mark, where they were ocoupied by hermit crabs.

Habitat.-The South Sea, on the shores of California; Edoux ! Kiener.

Seas of California; Deshayes.

St. Elena ; [? Cuming !] Reeve.

Mazatlan; Melchers! Menke.

San Blas; Dr. J. L. Burtt, U. S. N.! Mus. Acad. Nat. Sc. Philadelphia.,

Panama ; C. B. A.!

The California of the French authors is probably Lower California. On the reef at Panama, we obtained 1 perfect speoimen, which is $2 \frac{1}{2}$ inches long, and 5 others more or less imperfeot. In two large old shells the labrum is much thickened but not deeply serrated. A magnificent specimen has been presented to the Acad. Nat. So. Phil. by Dr. Burtt, who found it at San Blas : it is $3^{\frac{1}{3}}$ in. long.

\section{Buccinum ringens.}

Synonymy.

Buccinum ringens Reevo (non Phil.) Conch. Icon. pl. 7. f. 45 .

Dec. 1840.

In the Zeitschr. Malak, 1851, p. 59, Dr. Phillippi has inadvertently repeated this name for another species.

Station.-On the rocks at low water; Cuming! Reeve. We found this species chiefly under stones about the low water mark of neap tides.

Habitat.-Panama ; Cuming ! Reove. 
Panama; Jay.

Panama; C. B. A.!

We collected on the reef 275 specimens.

\title{
' 64. Buccinum sanguinolentum.
}

\author{
Synonymy.
}

Purpura sanguinolenta Ducl. in Guer. Mag. Zool. pl. 22.

f. 1. - - - - - - 1833.

Pollia hemastoma Gray in Zool. Beech. Voy.p.112. 1839.

Buccinum hamastoma Reeve Conch. Icon. pl. 7. f. 46. Dec. 1846. - Janelii Val. Voy. Venus. Moll. pl. 6. f. 1. 1846. - sanguinolentum Menke in Zeitsch. Malak. p. 180. Dec. 1847.

Station.-Under stones at low water; Cuming I Reeve.

A few of our specimens were found alive in the same situation; but as most of them were occupied by hermit crabs, at low water mark, it is probable that their favorite station may be somewhat lower.

Habitat.-Panama; Cuming! Reeve.

Mazatlan; Melchers! Menke.

Panama; Jay.

Taboga and Panama; C. B. A.

We collected 16 specimens.

\section{Buccinum Stimpsonianum. Nov. Sp.}

Shell long ovate-conic: rather pale slate color, more or less white above, with the revolving ridges brownish red or white where they cross the ribs, white in the upper half of the labrum, often with a broad white spiral band on the middle of the whorls: on each whorl with seven or eight stout transverse ridges, which are less prominent on the back of the last whorl; with several spiral linear ridges, of which four are visible on the penult whorl, which are obsolete between the transverse ridges, and are more numerous and smaller anteriorly; covered 
with five crowded spiral striæ: apex acute: spire conic: whorls eight, scarcely convex : aperture ovate : labrum much thickened, with a few plaits inside: columellar lip irregularly plaited: with a short well notched canal.

Mean divergence about $38^{\circ}$; length .72 inch; breadth .32 inch.

I take pleasure in dedicating this species to William Stimpson, Esq., whose researches on the Mollusca of this country will furnish a most valuable contribution to Malacology.

Station.-Under stones, near low water mark.

Habitat.-Panama; C. B. A.I

We obtained 19 specimens, of which a few only were alive.

\section{Dolium ringens.}

\section{Synonymy.}

Cassis ringens Swains. in Bligh Catal. App. p. 4. May 1822. Dolium dentatum Barnes Ann. Lyc. Nat. Hist. N. York

I. 135. 384. pl. 9. f. 3. - - - - 1824 .

Cassis ringens Sowb. Tank. Catal. p. 21.

Buccinum - Wood Ind. Test. Supp. pl. 4. f. 1. 1828.

Dolium personatum Menke Synop. p. 62. 1830.

Malea latilabris Valenc. in Humb. Rec. Obs. II. 325. 1833.

crassilabris Valenc. in Humb. Rec. Obs. II. 327. var. 1834.

Dolium latilabre Kiener Iconog. p. 14. pl. 4. f. 7.

Dolium plicosum Menke in Zeitsch. Malak. p.138. 1845.

ringens Reeve Conch. Icon. pl. 4. f. 5. Dec. 1848.

- dentatum Jay Catal. Dec. 1850.

- crassilabre Menke in Zeitschr. Malak. p. 182. Apr. 1851.

One of our specimens is 4.25 inches long, but most of them are small. One, with an excessively thickened lip and a deep groove behind the lip, is only 2.3 inches long. Mr. Reeve's figure represents a fine specimen 51 inches long. One in the Mus. Amb. is 6 inches long. Mr. Barnes notices a specimen 9 inches long and 7 inches wide. 
Station:-We found this species under and between stones at extreme low water mark.

Habitat.-Coast of Peru; Capt. Skiddy! Barnes.

Quito I. near Guayaquil; Don Pedro Abadea! Barnes.

Unknown; Wood.

Acapulco; Humboldt and Bonpland! Valenciennes.

"South Sea, Pacific Ocean, shore of Mexico, at Acapulco:" Kiener.

Payta, Peru; Cuming I Reeve.

Peru; Jay.

Acapulco; Jay, (a var.)

Mazatlan; Melchers I Menke.

Panama; C. B. A.!

Eight specimens were collected on the reef.

\section{Monoceros brevidentatum.}

Synonymy.

Buccinum brevidentatum Wood Ind. Test. Supp. pl. 4. f. 10. Purpura cornigera Blainv. in Nouv. Ann. Mus. I. 213. pl. 9. f. 10. - - - Mar. 1832.

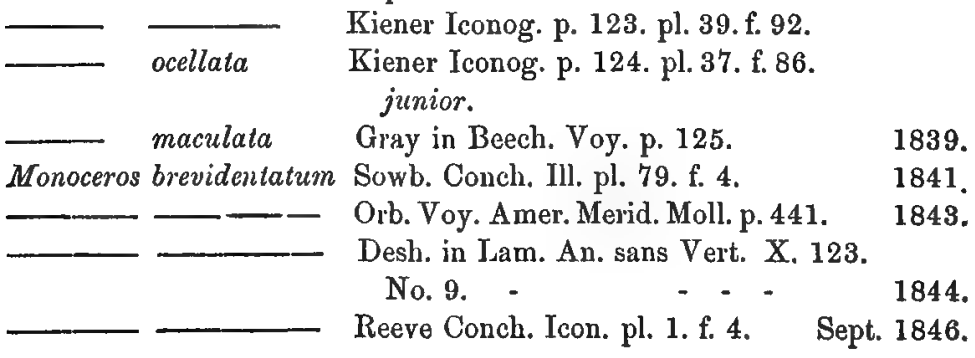

Station.-In crevices of rocks at low water; Cuming ! Reeve.

We found this species in the crevices and on the sides of rocks and stones, mostly at and above half tide level.

Habitat.-Unknown; Wood. Mazatlan; Botta ! Blainville. 
Shores of Peru; Kiener.

[Chili; Kiener, de P. ocellata.]

Pacific Ocean; Gray.

Payta ; Fontaine! Orbigny.

Seas of Peru; Deshayes.

Xipixapi, and Monte Christi; Cuming! Reeve.

Xipixapi ; Jay.

Monterey ; Major Rich! Gould MSS.

San Francisco; Col. E. Jewett 1 Gould MSS.

Panama; C. B. A.!

On the reef this species occurred plentifully. We collected about 300 specimens. According to Col. Jewett, this species occurs at San Francisco. We have seen the specimens, which are undoubtedly identical with the Panama shells; if there be no error in Col. Jewett's statement, this is the only species known to us, which is common to Panama and to San Francisco. But it is worthy of note that none of the Panama specimens appear in Col. Jewett's collection. Major Rich also states a habitat, Monterey, which is beyond the northern limit of the Panama zoological province.

\section{Momoceros cingulatum.}

\section{Synonymy.}

Buccinum cingulatum Wood Ind. Test. pl. 24. f. 167.

1818.

Monoceros

Lam. An. sans Vert. VII. 250. No. 1. Aug. 1822.

- Lam. Encyc. Meth. pl. 396. f. 4.

1824.

Sowb. Gen. f. 4.

1824.

Buccinum pseudodon Burrow Elem. Conch. pl. 26. f. 2.

Monoceros cingulatum Crouch Conch. pl. 18. f. 10.

Schub. et Wagn. Chemn. Supp. p. 150, pl. 233 , f. 4096.

1829.

Turbinella cinqulata Kiener Iconog. p. 36. pl. 20. f. 1.

Monoceros cingulatum Sowb. Conch. Ill. Catal. No. 1.

1841.

Reeve Conch. Syst. pl. 261, f. 4.

1842.

Turbinella cingulala Lesson Rev. Zool.

July, 1842.

Küst. Conch. Cab. p. 31. pl. 7. f. 8.

1844. 
Monoceros cingulatum Lam. An. sans Vert. X, 118. No. 1.

Desh. Ed. .

1844.

Reeve Conch. Icon. pl. 3. f. 11.

Sept. 1846.

Station.-In clefts of rocks at low water; Cuming ! Reeve.

We have found it in the same situation.

Habitat.-Unknown; Wood.

Western shores of Mexico; Humboldt and Bonpland! Lamarck.

Western shores of Mexico, those of California;

Kiener.

Panama; Sowerby ; also Jay.

Mazatlan; Melchers! Menke.

Panama; E. Jewett! Gould MSS.

Taboga, and Panama; C. B. A.!

We obtained 75 specimens, a majority of which are young, in part at Panama, but mostly at Taboga.

\section{Purpura Carolensis.}

Synonymy.

Purpura Carolensis Reeve Conch. Icon. pl. 11. f. 57. Sept. 1846.

Station.-Under stones at low water; Cuming! Reeve.

We found this species under stones and in the crevices of rocks near low water mark.

Habitat.-Charles I. Gallapagos; Cuming! Reeve.

Gallapagos; Jay.

Taboga; C. B. A.!

We collected 20 specimens, many of which are immature.

70. Purpura foveolata. Nov. sp.

Shell obliquely rhombic: white: with very prominent compressed transverse ridges, about nine on each whorl, and four spiral keels which are very prominent and much compressed, of 
which the upper one is seen on the middle of the whorls of the spire, and of which the anterior one is much less developed; with the intersections prominent; with rather fine spiral striæ: apex acute: whorls six; concave on both sides of the keel, with the suture indistinct: aperture long ovate, produced into a short canal: labrum rather thin, scalloped by the keels and finely serrated by the strix.

Mean divergence about $70^{\circ}$; length, .43 inch; breadth, .28 inch.

Station.-Under stones, near low water mark.

Habitat.-Panama; C. B. A.I

3 specimens were obtained.

\section{Purpura kiosquiformis.}

Synonymy.

Purpura kiosquiformis Ducl.in Ann. des Sc. Nat. XXVI. 107. pl. 1. f. 5 .

May 1832.

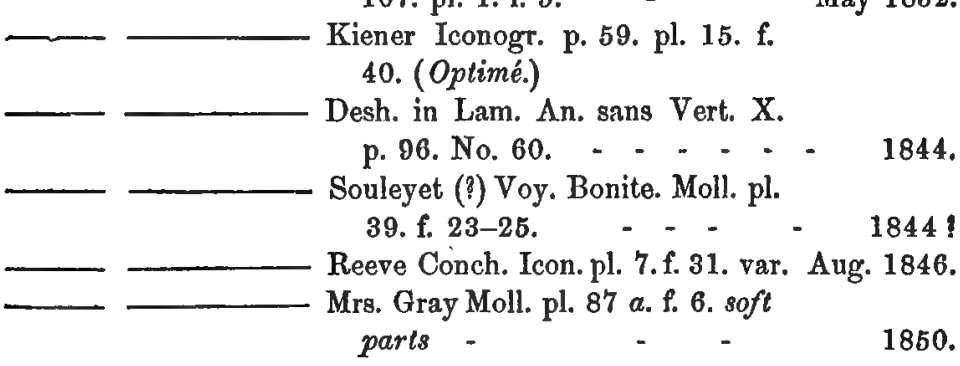

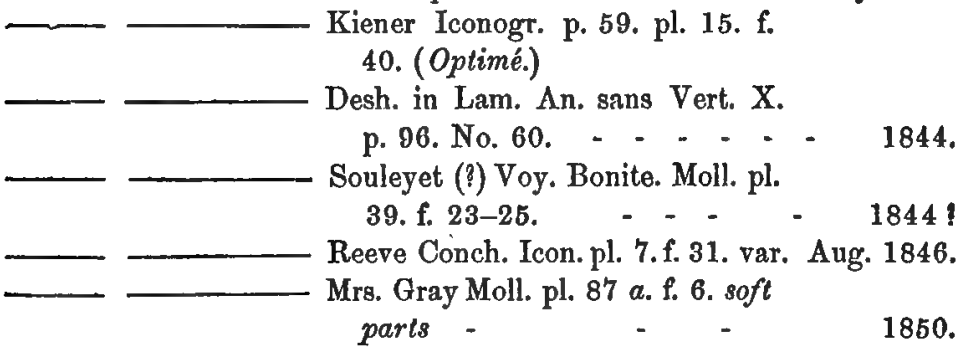

Station.-On rocky places at low water; Cuming 1 Reeve.

We found this species abundantly from half tide nearly up to the high water mark of neap tides, on rocks, and on the lower parts of the trunks and about the roots of trees, which were growing from a stony bottom.

Habitat.-Seas of New Holland; Duclos; also Kiener.

Seas of New Holland, according to Kiener; Deshajes. 
Bay of Panama; Cuming! Reeve.

West Columbia; Jay.

La Paz, in Lower California; Lt. Green! Gould MSS. : also Mus. Essex Inst.

Panama; Jewett ! Gould MSS.

Panama; C. B. A.!

Duclos' and Kiener's statement is probably erroneous.

We collected 170 specimens. The variety, figured by Mr. Reeve, with two keels almost equally developed, we did not find: but several specimens have a second keel moderately developed.

\section{Purpura -. Sp. indet.}

This shell resembles $P$. kiosquiformis, is longer, with the whorls revolving more obliquely, and with other differences. One specimen was obtained. It is not sufficiently perfect for description.

\section{Puxpura melo.}

Synonymy.

Purpura crassa Blainv. in Nouv. Ann. Mus. I. 241. No. 83. pl. 12. f. 4.

March 1832.

Sowb. Gen. No. 42. f. 5.

1824.

melones Ducl. Ann. des Sc. Nat. XXVI. 105.

pl. 1.f. 2. - - - -

Kiener Iconog. p. 125. pl. 39. f. 93. junior.

- Kiener Iconog. p. 125. pl. 39. f. 93. junior
Reeve Conch. Syst. pl. 259. f. 5. junior.
Desh. in Lam. An. sans Vert. X. 106.

May 1832.

No.71. - - -

1842.

1844.

melones Reeve Conch. Icon. pl. 4. f. 19.

Aug. 1846.

Station.-Under stones at low water; Cuming! Reeve.

Our specimens were found about the sides and crevices of rocks, from the low water mark of neap tides up to three-quarters tide.

Hulilat.-Unknown; Blainville; also Duclos. 
Shores of Peru ; Kiener: also Deshayes.

Monte Christi; Cuming! Reeve.

Monte Christi and Peru; Jay.

Panama; E. Jewett ! Gould MSS.

Panama and Taboga; C. B. A. 1

We collected 150 specimens, pártly at Taboga, but mostly at Panama. Old specimens become very thick, and are rectangularly shouldered on the last whorl.

\section{Purpura osculang. Nov. sp.}

Shell obliquely rhombic: dingy white, pure white within : with, on each whorl, 9 transverse, rather small, prominent, wellrounded ridges, which are produced to the anterior extremity: with crowded spiral closely imbricately scaled narrow ridges, which traverse the transverse ridges, and of which the alternate ones are more prominent: apex acute: spire with the outlines rectilinear: whorls six and one-half, convex, with a wellimpressed suture: aperture obovate: labrum finely scalloped, transversely grooved within: with a short, deeply-notched canal. Allied to Purpura galea and other kindred species.

Mean divergence about $70^{\circ}$; length, .27 inch; breadıh, .17 inch; length of spire, .12 inch.

Station.-Unknown.

Habitat.-Panama ; C. B. A.! 2 specimens were obtained.

\section{Purpura tecta.}

Synonymy.

Purpura callosa Sowb. (non Lam.) Gen. No. 42. f. 9. 1824. Buccinum tectum Wood Ind. Test. Supp. pl. 4. f. 13. Purpura angulifera Ducl. in Ann. des Sc. Nat. XXVI. 107. pl. 1. f. 6 1828. Kiener Iconog. p. 60. pl. 15. f. 43.

Cuma sulcata Swains. Malac. p. 87. f. 4. p. 307.

May 1832. 
Purpura callosa Reeve (non Lam.) Conch. Syst. pl.

Turbinella -— Lesson Rev. Zool. July 1842.

\begin{tabular}{lll}
\hline tectum Reeve Conch. Icon، pl. 8. f. 41. & Aug. 1847. \\
\hline
\end{tabular} 260. f. 9. - - - - - - - 1842 .

The specific name given in Sowb. Gen. was preoccupied by Lamarck for a shell, which, according to Kiener and to Reeve, is only a variety of $P$.bufo; but Deshayes regards it as a good species. We have therefore used the name given by Wood, after Reeve and Jay.

Station.-In 10 fathoms sandy mud; Cuming ! Reeve.

We found our specimens in the crevices of rocks, between the low water marks of the neap tides and of the spring tides.

Habitat.-Unknown; Wood: also Duclos.

Shores of Chili; Kiener.

Real Llejos; Lesson.

Bay of Panama; Cuming! Reeve.

Panama; Jay.

Panama; C. B. A.I

We collected 60 specimens on the reef. All of them are of the var. $b$ Reeve.

\section{Purpura undata.}

Synonymy.

Purpura undata Lam. (non Orb.) An. sans Vert. VII. 238. No. 10. (Syn. Excl.) -

Blainv. in Nouv. Ann. Mus. I. 217. pl. 0.
f. 12.
Valenc. in Humb. Rec. Obs. II. 315.
Kiener Iconog. p. 116. pl. 34. f. 81. (Var.
$s$ Excl.)

Blainv. in Nouv. Ann. Mus. I. 217. pl. 0.
f. 12.
Valenc. in Humb. Rec. Obs. II. 315.
Kiener Iconog. p. 116. pl. 34. f. 81. (Var.
$s$ Excl.)

Aug. 1822.

Mar. 1832.

1833.

$s$ Excl.)

—— Lam. An. sans Vert. X. 67. No. 10. Desh.

Ed.

Souleyet (?) Voy. Bonite Moll. pl. 39.

1844.

f. 17-19. - - . - - 1844 ? 
Purpura undata Reeve Conch. Icon. pl. 9. f. 43. Sept. 1847. - homastoma Menke (non Lam.) Zeitschr. Malak.

undata Mrs. Gray, Moll. pl. 87. a. f. 1. 1850. p. 182. - - - - Nov. 1847.

Station.-Under stones at low water; Cuming ! Reeve.

We found this species under stones near the low water mark of the neap tides.

Habitat.-Unknown; Lamarck.

Acapulco; Humboldt and Bonpland I Valenciennes.

South Sea and Shores of St. Helena; Kiener.

Monte Christi ; Cuming I Reeve.

Monte Christi ; Jay.

Panama; C. B. A.l

We collected 180 specimens on the reef at Panaman-This species and $P$. hamastoma are sometimes confounded. The latter inhabits only the Mediterranean and the eastern shores of the Atlantic, in warm latitudes. It is, therefore, extremely probable that Dr. Menke's $P$. homastoma from Mazatlan is the true $P$. undata. As Kiener confounds three distinct species, there can be no advantage in learning whether his "Sainte Hélène" is St. Helena in the Atlantic, or St. Elena in West Columbia.

COLUMBELLA. Numerous species of this genus, and an incredible multitude of individuals were found at Panama. Many of the species are among the most beautiful in the genus. Perhaps no other fauna equals the marine Pacific fauna of tropical America for its development of this genus in these three characters-number of typical forms, number of individuals, and their size and elegance. The number of species which have been collected at Panama much exceeds the number in the entire genus which were known to Lamarck. While very few of the species which we collected have been described in 
M. Kiener's monograph of the genus, most of them are easily determined with Mr. Sowerby's accurate figures. To these the descriptions of many of the species by Deshayes (in Lam. An. sans Vert.) have been found a valuable addition.

\section{Columbella atramentaria.}

Synonymy.

Columbella atramentaria Sowb. in Proc. Zool. Soc. Lond.

p.51. - - - March 1844. Sowb. Thes. Conch. p. 134. No.

67. pl. 40. f. 174 . -

1844.

This species closely resembles $C$. nigricans, differing chiefly in the shorter spire and more obese outline. Its coloring is also different from the common style of that species, consisting of pale rectangular spots on a greyish black ground.

Station.-Wo found this shell under stones near low water mark.

Habitat.-Chatham I., Gallapagos.-Sowerby.

Panama.-C. B. A.!

We obtained only three specimens.

78. Columbella bicamalifera.

Synonymy.

Columbella bicanalifera Sowb. in Proc. Zool. Soc. Lond.

p. $113 . \quad$ - June 1832.

Müll.Synop. Nov.Test.Viv. p. 81.
Sowb. Thes. Conch. p. 137. No. 77.
pl. 39. f. 144. Sowerby.

Habitat.-Gallapagos; Cuming ! Sowerby : also Müller.

Taboga; E. Jewett! Gould MSS.

Panama; C. B. A.! 
We were indebted to the hermit crabs for 36 specimens, which were taken, in a more or less perfect state of preservation, about two miles east of Panama.

\section{Columbella Boivinii.}

Synonymy.

Columbella Boivinii Kiener Iconog. p. 47. pl. 11. f. 1.

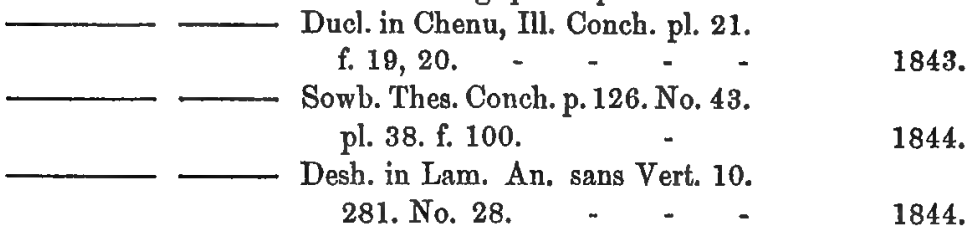

Slation.-We found these mollusks between half and three quarters tide, in the margin of water left by the ebbing tide in cavities of the rocks.

Habitat.-Unknown; Kiener. Gulf of Nicoya; Hinds! Sowerby. Gulf of Nicoya; Deshayes: also Jay. Panama and Taboga; C. B. A.!

Our specimens were obtained chiefly on the rocks in front of the fortifications in the sea wall of Panama. Immature individuals were quite numerous, but only 50 adult specimens were taken alive.

\section{Columbella conspicua. Nov. sp.}

Shell ovate-conic: with a broad white spiral band on the convexity of the whorls, on each side of which is a broad band of brownish orange; anteriorly white with irregular brown spots; with deep brown spots near the summits of the alternate ridges; with, on each whorl, nine very prominent obtuse transverse ridges, which are obsolete at the upper part of the whorls; with coarse spiral strix, which traverse the ridges except at the summit of the middle and most prominent part : apex suba- 
cute; spire with the outlines nearly rectilinear; whorls eight, convex, with a moderately impressed suture; last whorl sub. angular; aperture a little wider above; labrum moderately thickened, with a few wrinkles on the inside : notch wide and deep.

Mean divergence about $35^{\circ}$ : length .21 inch; breadth, .1 inch ; length of spire, .12 inch.

Station.-Unknown.

Habitat.-Panama; C. B. A. 1

Only one specimen of this elegant shell was found.

\section{Columbella costellata.}

Synonymy.

Columbella costellata Brod. and Sowb. in Zool. Journ.

IV. 376. - - - - - - - - 1829.

Sowb. in Proc. Zool. Soc. Lond.

p. $118 . \quad$ - June 1832.

Müll. Synops. Nov. Test. Viv. p. 88. May 1836.

Gray in Zool. Beech. Voy. pl. 36.

f. 9? - - - - - - 1839.

Ducl. in Chenu Ml. Conch. pl. 25. f.

$11,12 . \quad-\quad \quad-\quad-1843$.

Sowb. Thes. Conch. p. 137. No. 79.

pl. 39. f. 147. - - $\quad$ - 1844.

We have had some difficulty in determining whether our shells belong to this species or to $C$. scalarina. Taking the descriptions and figures by Mr. Sowerby, the ribs in $C$. costellata are said to fall far short of the anterior extremity, but to be prolonged in C. scalarina, although the figures of these species exhibit no difference in this respect: most of our specimens have them prolonged, but the character is not constant. In other respects the figures of the two species are very different, and that of $C$. costellata well represents our shells. Many of the specimens are larger than this figure. 
In Chenu, the figures of both species have the ribs prolonged. In these figures the ribs are more distant in C. costellata than in C. scalarina. The figure of the former very exactly represents our shells.

Station.-A single specimen was found at the depth of 16 fathoms; Cuming I Sowerby. Our specimens were found under stones near low water mark.

Habitat.-Panama; Cuming I Sowerby : also Miiller.

Panama and coast of Africa; Gray.

Panama; C. B. A. 1

We collected 25 specimens on the reef. Mr. Gray must be in error when he includes the coast of Africa in the habitat.

\section{Columbella diminuta. Nov, sp.}

Shell subfusiform : pale yellowish brown, black or brownish black anteriorly : ribbed, with the interstices covered with spiral striæ, which are coarser anteriorly where the ribs are obsolete; apex acute: spire conic: whorls seven, scarcely convex: with the suture lightly impressed: aperture rather narrow: labrum variciform, broadly thickened, sinuate posteriorly, crenulated within: columellar lip with the granules obsolete.

Mean divergence about $45^{\circ}$; length, .155 inch; breadth, .07 inch; length of spire .08 inch.

This species resembles a dwarfed $C$. nigrescens.

Station.-Under stones near low water mark we found this shell.

Habitat.Panama; C. B. A.1 19 specimens were obtained.

\section{Columbelía dorsáta.}

Synonymy.

Columbella dorsata Sowb. in Proc. Zool.Soc. Lond.p.120. June 1832. - Mutler Synop. Nov. Test Viv p. 01. May 1836. - Reeve Conch. Syst. pl. 257. f. 7. 1842. 
Columbella dorsata Ducl. in Chenu Ill. Conch. pl. 20. f. $17,18$.

Sowb. Thes. Conch. p. 136. No. 75. pl. 39. f. 140-1. - $\quad$ - - - - 1844.

- Desh. in Lam. An. sans Vert. X. 291. No. 45.

1844.

Station.-Unknown.

Habitat.-I. of Muerte, Bay of Guayaquil ; Cuming ! Sowerby : also Müller.

Shores of Columbia; Deshayes.

I. of Muerte; Jay.

Panama; C. B. A.!

We obtained only 1 dead shell of rather small size.

\section{Colmmbella finctuata.}

Synonymy.

Columbella fluctuata Sowb. in Proc. Zool. Soc. Lond. p. 115. - - - - Juno 1832. suturalis Griff. Cuv. An. King. Moll. pl. 41. f. 6 ? 1834.

\begin{tabular}{rll}
\hline fluctuata & Müll. Synop. Nov. Test. Viv. p. 84. & 1836. \\
\hline suturalis & Kiener Iconog. p. 45. pl. 9. f. 2. &
\end{tabular}

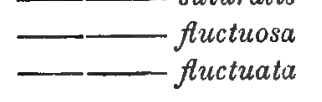

Ducl. in Chenu, pl. 13. f. 11, 12. Sowb. Thes. Conch. p. 138. No. 82. pl. 39. f. 150 . 1843.

- Desh. in Lam. An. sans Vert. X. 283. No. 33. 1844. 1844.

Station-Under stones; Cuming! Sowerby: also Müller. Our specimens were found under stones a little above the low water mark of neap tides.

Habitat.-Gulf of Nicoya; Cuming! Sowerby : also Müller.

Shores of Peru; Kiener.

Gulf of Nicoya; Deshayes : also Jay.

Panama; C. B. A.!

We collected on the reef about 400 specimens of this elegant species. 
COLUMBELLA.

Panama Shells.

\section{Columbella fulva.}

Synonymy.

Columbella fulva Sowb. in Proc. Zool. Soc. Lond. p. 115. June 1832.

- Miill. Synop. Nov. Test. Viv. p. 83. 1836.

- Sowb. Thes. Conch. p. 138. No. 80. pl.

39. f. 148. - - $\quad 1844$.

- Desh. in Lam. An. sans Vert. X. 281, No. 29.1844.

Station.-Under stones; Cuming! Sowerby.-Under stones; Deshayes.

Our specimens were found in the same situation, not far from low water mark.

Habitat.-Panama; Cuming I Sowerby : also Müller.

Panama; Deshayes: also Jay.

Mazatlan; Melchers! Menke.

Panama; C. B. A.1

We obtained only 3 specimens.

\section{Columbella fuscata.}

Synonymy.

Columbella fuscata Sowb. in Proc. Zool. Soc. Lond. p. 117.

June 1832.

Müll. Synop. Nov. Test. Viv. p. 88.

1836.

meleagris Kiener Iconog. p. 10. pl. 3. f. 3.

Ducl. in Chenu Ill. Conch. pl. 4.

f. 15,16 . and pl. 16. f. 13, 14. -

Orl. Voy. Amer. Merid. Moll. p. 430.
fuscata Sowb. Thes. Conch. p. 114. No. 11.

1840.

pl. 36. f. $21,25$.

1843.

Desh. in Lam. An. sans Vert. X.

276. No. 22. - - - - -

1844.

1844.

Station.-Under stones; Cuming! Sowerby.

Our specimens were found under stones a little above low water mark. 
Habitat.-Common at Panama, St. Elena, and Monte Christi ;

Cuming! Sowerby; also Müller.

Shores of San Blas; Kiener.

Acapulco; Lesson.

Panama, St. Elena, and Monte ${ }^{\circ}$ Christi; Deshayes.

Mazatlan; Melchers! Menke.

Panama; Jay.

Taboga; C. B. A.I

At the season of our excursion to Panama, specimens were scarce. We obtained only 4 living and 2 dead shells. One of these, although mature, is only .33 inch long.

\section{Columbella gibberula.}

Synonymy.

Columbella gibberula Sowb. in Proc. Zool. Soc. Lond.

p. 115. - - - - - June. 1832.

\begin{tabular}{lll}
\hline Müll. Synop. Nov. Test. Viv. p. 83. & 1836. \\
Ducl. in Chenu Ill. Conch. pl. 12. & \\
f. 5, 6. - - - - - & 1849. \\
Kiener Iconog. p. 44. pl. 15. f. 3. & \\
Sowb. Thes. Conch. p. 136. No. & 1844. \\
136. pl. 39. f. 142-3. - - & \\
Desh. in Lam. An. sans Vert. X. & \\
292. No. 47. . - - & 1844.
\end{tabular}

Station.-In sandy mud, at 11 fathoms depth ; Cuming! Sowerby.

Habitat.-Bay of Caraccas, and Puerto Portrero; Cuming! Sowerby; also Müller.

Shores of Chili; Kiener.

Shores of Southern and Central America; Deshayes.

Central America; Jay.

Taboga; E. Jewett! Gould MSS.

Taboga; C. B. A. I

We found 7 specimens occupied by hermit crabs in a perforated log. The northern boundary of Chili is the most extreme 
southern limit, so far as authentic testimony goes, reached by any- of the species which inhabit the Bay of Panama, and we have, therefore, some doubt of the accuracy of Kiener's statement.

\section{Columbella gracilis. Nov. sp.}

Shell long ovate conic; upper whorls pale brown; with irregular spots of darker reddish brown, mostly near the suture and nearly covering the last whorl, on the periphery of which is a whitish band articulated with arrow-headed brown spots: with very numerous small ribs, of which the posterior ends only remain on the back of the last whorl; anteriorly with revolving striæ: apex acute: spire conic: whorls eight, scarcely convex, with the suture distinctly impressed: aperture narrow: labrum variciform, rather sharp-edged, thickened behind, a little sinuate posteriorly, with a few granules inside: columellar lip nearly smooth.

Mean divergence about $37^{\circ}:$ length .3 inch; breadth .125 inch: length of spire .2 inch.

Var. with the color nearly uniform dingy brown.

Station.-Unknown.

Habitat.-Panama; C. B. A. 1

We were indebted to the hermit crabs for 7 specimens.

\section{Columbella guttata.}

\section{Synonymy.}

Columbella guttata Sowb. in Proc. Zool. Soc. Lond. p. 118. June 1832. Müll. Synop. Nov. Test. Viv. p. 88. May 1836. cribraria Sowb. (non Lam.) Thes. Conch. p. 129.

$$
\text { No. 51. pl. 38. f. 112. - - - - - } 1844 \text {. }
$$

Mr. Sowerby, having relinquished the species, has re-used the name for quite a different species, in Proc. Zool. Soc. Lond. p. 50. Mar. 1844, and in Thes. Conch. p. 131. pl. 39. f. 124 .*

* In his Index this species is called $\alpha$ punctata. 
We have excluded from the synonymy the $O$. cribraria (Buc=1 cinum) of Lamarck and of some other authors, because at least two species appear to have been confounded. One inhabits the Panama zoological province, and the other, the Caribbean seas. The Caribbean type is that which gewerally bears the Lamarckian name in the collections of the United States. In Jamaica, we have taken several varieties of it, all of which are distinguishable, by slight differences, from the Panama type. Kie. ner's figures (Buccinum, , pl. 16. f. 57) resemble the Caribbean. rather than the Pacific type. ' This author, however; says of the species :- "Habite les mers des Indes, l'île de l'Ascension et les côtes de Groré, où elle est très abondante." And Lamarck gives as the habitat of his shell, "les mers du Java, M. Leschenault." The.Caribbean shell, however, has been described by Professor Dunker (Zeitschr. Malak.1847.p. 64 ; and in Phil.i Abbild. III. pl. 2. f. 7. 1849) under the name of Buccinum parvulum. Whether there be also an Indian species, which furnished the Lamarckian type, remains to be ascertained. In the "Voyage of the Astrolabe," II. 421. pl. 30. f. 21; 22, we recognise the Caribbean type (badly colored)... It was obtained at Ascension Island.

Station.-Under stones; Cuming ! Sowerby.

Our specimens were found under stones, not far above low water mark.

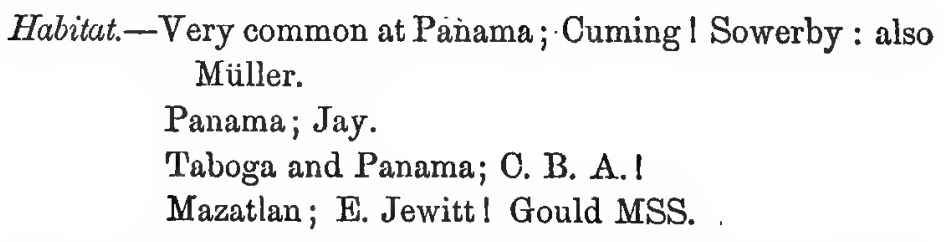

Most of our specimens were found at Taboga. We collected about 75 individuals of the type which is figured in the Thes. Conch., and as many of a type, which is much more finely and densely dotted with the white or even reticulated only with the. brown color. Most. of the former. are rather larger than the 
figure referred to; but the latter differ much in size: Sorme of these are as small as the Caribbean type. Individuals were by no means common at the time of our visit to Panama.

\section{Columbella hamastoma.}

\section{Synonymy.}

Columbella hamastoma, Sowb. in Proc. Zool, Soc. Lond. ,

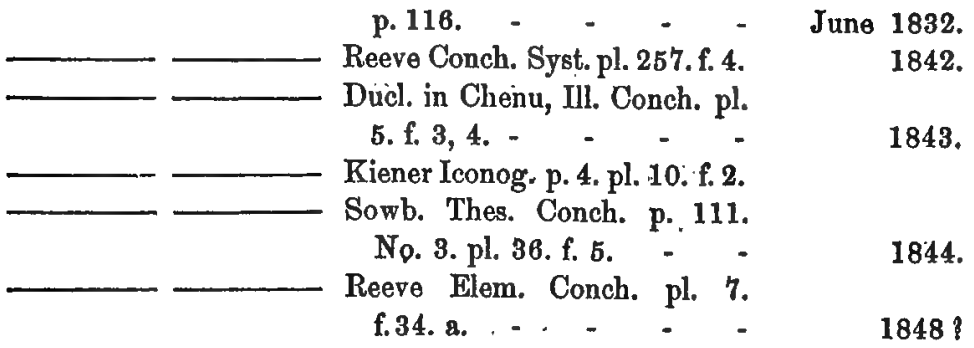

Station.-Under stones; Cuming ! Sowerby.

Habitat.-Panama, and the Gallapago Is.; Cuming ! Sowerby.. Shores of California; Kiener. .

Panama, Gallapago Is. ;. California ; Jay...

Panama; C. B. $\mathbf{\Lambda}$ !

We found but one dead specimen, in which the colors of the last whorl consist of two white and two brown alternating bands.

\section{Columbella harpiformis.}

\section{Synonymy.}

Columbella harpiformis Sowb. in Proc. Zaol. Soc. Lond.

p. $113 . \quad$ - - - - June, 1832.

\begin{tabular}{lll}
\hline Müll. Synop. Not. Test. Vivi: p. 80. & 1836. \\
\hline Reeve. Conch. Syst. pl. 257. f. 3: & 1842. \\
Griff. An. King. Moll. pl. 37. f. 2. & 1834.
\end{tabular} citharula Ducl. in Chenu, Ill. Conch. pl, 10.

$$
\text { f. } \mathbf{9}, \mathbf{1 0} \text {. }
$$


Columbella citharula Kiener Iconog. p. 54, pl. 16. f. 2. harpiformis Sowb. Thes. Conch. 112. No. 6.

pl. 36. f. 10. 12.

1844.

Station.-On dead shells at a depth of 10 fathoms; Cuming ! Sowerby. Our specimens were found under stones at low water mark.

Habitat.-Bay of Panama; Cuming! Sowerby: also Miuller. Unknown; Kiener.

Mazatlan; Melchers! Menke.

Panama; Jay.

Panama; C. B. Al

We obtained on the reef 9 specimens of this rare shell.

\section{Columbella labiosa.}

Synonymy.

Columbella labiosa Sowb. Gen. pt. 9. f. 2.

1824.

Crouch Conch. pl. 19. f. 7.

1826.

- Reeve Conch. Syst. pl. 258. f. 2.

1842.

Souleyet (?) Voy. Bonite. Moll. pl. 45.

f. 8-12.

$1844 ?$

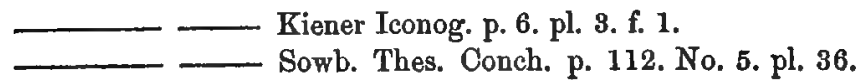

f. 8,9 . - - - - $\quad 1844$.

Station.-We found this species under stones near low water mark.

Habitat.-Unknown; Kiener.

Found abundantly at St. Elena; Cuming I Sowerby.

St. Elena; Jay.

Taboga; C. B. A.I

We obtained 4 mature and 6 young specimens. 
COLUMBELLA.

93. Columbella Iyrata.

Synonymy.

Columbella lyrata Sowb. in Proc. Zool. Soc. Lond. p. 114. June 1832.

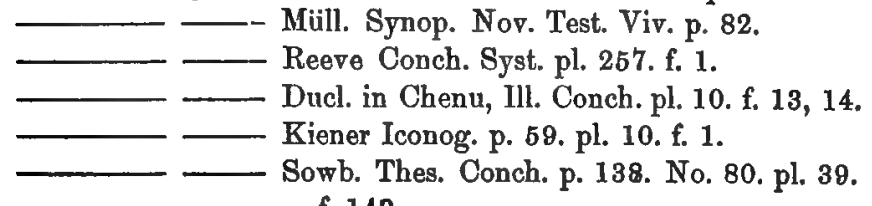

1836.

1842.

f. 149 .

1844.

Station.-Under stones; Cuming ! Sowerby. Our specimens were found under stones at low water mark.

Habitat.-Bay of Panama and Chiriqui ; Cuming! Sowerby: also Müller.

"Les rochers des côtes de Panama;" Kiener.

Panama; Jay.

Panama; C. B. A.I

We obtained on the reef 19 specimens of this beautiful shell.

\section{Columbella major.}

Synonymy.

Columbella major

gibbosa

major

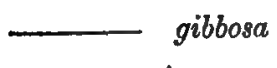

\section{getrombeformis Var. Kiener}

f. 5,61 ?

Sowb. in Proc. Zool. Soc. Lond.

p. 119 -

June 1832.

Valenc. in Humb. Rec. Obs. II. 331 ?

Múll. Synop. Nov. Test. Viv. p. 90.

Ducl. in Chenu, Ill. Conch. pl. 5.

$$
\text { f. } 5,6 \text { ? }
$$

1833.

May 1830.

f. $1 . a$.

Sowb. Thes. Conch. p. 110. No. 2. pl. 36. f. 3, 4, 6 .

Desh. in Lam. An. sans Vert. X. 274. No. 19. - - -

Desh. Traité Elem. pl. 120. f. 11, 12.

JULY, 1852
AN风. Lyc. NAT. Hist. 
Station.-Under stones; Cuming! Sowerby. Our specimens were found under stones near low water mark.

Habitat.-I. of Muerte; Cuming ! Sowerby: also Muiller.

Seas of South America; Deshayes.

Central America; Jay.

Mazatlan; It. Green I Gould MSS. : also Mus. Essex Inst.

Panama; E. Jewett ! Gould MSS.

Taboga; C. B. A.I

We obtained 30 specimens, most of which were taken alive. They are more intensely colored than Mr. Sowerby's figure, and several have the spire more elevated.

\section{Columbella modesta.}

Synonymy.

Buccinum modestum Powis in Proc. Zool. Soc. Lond. p. 94. June 1835. Columbella modesta Rould MSS.

Station.-Muddy gravel at a depth ranging from 7 to 17 fathoms; Cuming I Powis; also Reeve.

Our specimens were brought up by hermit crabs, which frequented rocks, and were especially numerous about a pile of railroad iron lying in the soft ooze not far above low water mark.

Habitat.-Bay of Montija; Cuming! Powis : also Reeve.

West Columbia; Jay.

Santa Barbara; E. Jewett! Gould MSS.

Panama ; C. B. A.!

We collected 80 specimens, mostly in good condition.

96. Columbella maesta. Nov, sp.

Shell slender, subfusiform: black, or brownish black, with the color less intense on the back of the last whorl: upper 
whorls smooth or with one or two revolving strix; middle whorls with twelve to fifteen ribs, with the interstices spirally striate; with the ribs and stria obsolete on the back of the last whorl; more strongly striated anteriorly: apex acute: spire very slender: whorls eight, scarcely convex, with the suture lightly impressed: aperture long and narrow: labrum variciform, very thick, sinuate posteriorly, crenulated within: colu. mellar lip nearly smooth.

Mean divergence about $35^{\circ}$; length .3 inch; breadth .11 inch; length of spire .17 inch.

Station.-We found this species about sticks and stones in a grove of trees, a little above half tide level.

Habitat.-Panama; C. B.A.!

58 specimens were obtained about two miles west of the city.

\section{Columbella nigricans.}

Synonymy.

Columbella nigricans Sowb. in Proc. Zool. Soc. Lond. p. 52. Mar. 1844. Ducl. in Chenu, Ill. Conch. pl. 21. f. 7, 8.
Sowb. Thes. Conch. p. 143, No.95. pl. 40. f. 172 .

Station.-Our specimens were found under stones, between half tide and low water mark.

Habitat.-Gallapago Is.; Cuming ! Sowerby.

Gallapago Is. ; Jay.

Taboga; E. Jewett ! Gould MSS.

Panama and Taboga; C. B. A.!

We obtained on the reef about 120 specimens of large size, most of which are colored as described by Mr. Sowerby. About 500 specimens of small size were collected, among which there is a great diversity of coloring. Many have a white spiral band. All shades of brown occur. Some of the small individuals are likely to be confounded with $C$. parva Sowb. ; but 
in C. nigricans a revolving impressed line cuts the posterior ends of the ribs.

\section{Columbella parva.}

Synonymy.

Columbella parva Sowb. in Proc. Zool. Soc. Lond. p. 52. Mar. 1844. Sowb. Thes. Conch. p. 142. No. 83. pl. 40.

f. 170 . $\quad \ldots$

Station.-Under stones; Cuming! Sowerby.

Ilabitat.-Monte Christi ; Cuming I Sowerby. Panama; C. B. A.!

We found only one specimen.

99. Columbella pulchrior. Nov. sp.

Shell rather long ovate: with a whitish revolving band next below the suture articulated with large spots of a dark slate color; with a translucent ground of pale yellowish brown, on which are placed in quincunx order rather numerous, excessively minute sharply defined dots of reddish brown; with one or two large irregular spots of dark brown near the end of the last whorl: surface smooth and shining: apex acute: spire conic: whorls six or seven, scarcely convex, with the suture lightly impressed: aperture narrow: labrum rather sharp, thickened behind, with a few granules inside: columellar lip nearly smooth.

Mean divergence about $45^{\circ}$; length .15 inch; breadth .07 inch; length of spire .075 inch.

Station.-Under stones near low water mark.

Habitat.-Panama; C. B. A.!

We found of this rare and elegant little shell only 5 specimens. 
COLUMBELLA.

Panama Shells.

100. Columbella pygmaea.

Synonymy.

Columbella pygmoea Sowb. in Proc. Zool. Soc. Lond. p. 119. June 1832. Müll. Synop. Nov. Test. Viv. p. $90 . \quad$ May 1836. Sowb. Thes. Conch. p. 141. No. 80. pl.

40. f. 163.

1844.

Station.-On dead shells in saudy mud, at a depth of 10 fathoms; Cuming! Sowerby.

Our specimens were found under stones at low water mark.

Habitat_-St. Elena ; Cuming I Sowerby : also Müller.

St. Elena; Jay.

Panama ; C. B. A. 1

We collected on the reef 185 specimens of this pretty species.

\section{Columbella rugosa.}

Synonymy.

Columbella rugosa Sowb. in Proc. Zool. Soc. Lond. p. 115. June 1832. Müll. Synops. Nov. Test. Viv. p. 84.

1836.

Soverbyi Ducl. in Chenu, Ill. Conch. pl. 19. f. 5. 6.? 1843.

bicolor Kiener Iconog. p. 46. pl. 16. f. 4.?

Sowb. Thes. Conch. p. 130. No. 53. pl. 38.

f. 114-5.

1844.

There are three principal varieties, which freely graduate into each other. The first has a few distant tubercles on the lower whorls: the second has ribs on the first part of the last whorls, but they are rather short and wide: in the third these ribs of the last whorl are narrow and long. Specimens of a diminutive size are very common. About two thirds of those which we collected are from .60 inch to .75 inch long; about one fourth of them range from .35 inch to .50 inch in length. The epidermis is brown, and very thin but tough.

Station.-Under stones; Cuming 1 Sowerby.

Our specimens were found under stones between half tide and the low water mark of neap tides. 
Habitat.-Panana and Xipixapí; Cuming! Sowerby; also Müller.

Panama and Xipixapi ; Jay.

i Real Llejos; Mörch.

Panama and Taboga; C. B. A. 1

We collected about 1500 specimens on the reef, where it is the most abundant species in the genus.

\section{Columbella strontibiformis.}

Synonymy.

Columbella strombiformis Lam. An. sans Vert. VII. 293.

$$
\text { No. } 1 .
$$

Aug. 1822.

Sowb. Gen. pl. - f. 1.

1842.

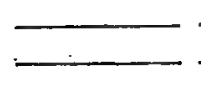

i. Desh. in Encyc. Meth. Vers. II.

p. 251. (pag, ser. 1.) No. $1 . \quad-1830$.

$\because$ Blainv. Malac. pl. 29. f. 23. May, 1825.

Buccinum strombiforme Wood Ind. Test. Supp. pl. 4. f. 18. - - - - - 1828.

Columbella strombiformis Valenc. in Humb. Rec. Obs. II. 330. - - $\quad$ - $\quad 1833$.

$\longrightarrow \begin{aligned} & \text { Reeve Conch. Syst. pl. 257. } \\ & \text { f. 1. (malé.) - } 1842 .\end{aligned}$

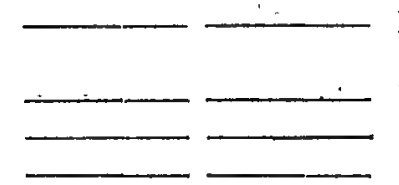

Ducl. in Chenu, Ill. Conch. pl. 5. f. $7,8$.

Kiener Iconog. p. 3. pl. 1. f. 1.

Orb. Voy. Amer. Merid. Moll. 429.1843. Sowb. Thes. Conch. p. 110. No. 1. pl. 36. f. 1. 2. - - Lain. Án. sans Vert. X. 266. "No. 1. Desh. Ed. - - - : ‘ 1844.

Station.-Unknown.

Habitat.-Coasts of Acapulco; Humboldt and Bonpland! Lamarck.

Acapulco; Humbolàt and Bonpland! Valenciennes.

'. '. Coasts of Peru; Deshayes :-also Kiener.

I. of Muerte; Cuming! Sowerby. 
Acapuloo; Lesson.

:Payta; Fontaine I'D'Orbigny.

Mazatlan; Melchers I Menke.

Acapulco; Jay.

Mazatlan; Lt. Green! Gould MSS.

Taboga; C. B. A.!

We obtained only 1 specimen.

103. Cólumbelia' tesselata. Nov. sp.

Shell rather long ovate: dark sea-green, tinged with black or brown, fading to a brownish red; more or less tesselated with nearly quadrangular white spots: with about fifteen stout approximate ribs, which lean forward, and which 'are obsolete on the back of the last whorl; with all the surface ridged by strongly impressed revolving strix: apex acute: spire conic: whorls eight, scarcely convex, with a distinct suture: aperture rather long: labrum variciform, thick behind, a little sinuate posteriorly, with three or four granules inside : columellar lip slightly granulous.

Mean divergence about $48^{\circ}$; length, .225 inch; breadth, .105 inch; length of spire, .13 inch.

This specics rescmbles the small varicty of $C$. nigricans. It also resembles $C$. lentiginosa Hinds (Zool. Sulph. Moll. pl. 10. f. 21, 22), in coloring and sculpture; but the latter is represented as being much wider and as having a short spire.

Station.-This species was found under stones, near low water mark.

Habitat.-Panama ; C. B. A. 1

We collected 27 specimens.

\section{. 104: Columbella turrita.}

Synonymy.

Columbella turrita Sowb. in Proc. Zool. Soc. Lond. p. 115. .Juno, 1832. 
Columbella turrita Müll. Synop. Nov. Test. Viv. p. 83.

1836.

- Sowb. Thes. Conch. p. 135. No. 73. pl. 39. f. 137.

1844.

- Desh. in Lam. An. sans Vert. 10.290.

No. 44.

1844.

Station.-In coarse gravel and sandy mud, at a depth of 10 fathoms; Cuming! Sowerby.

Habitat.-Bay of Montija and St. Elena, Cuming! Sowerby. Central America; Deshayes.

St. Elena; Jay.

Panama; C. B. A. I

We were indebted to a hermit crab for one specimen.

\section{Columbella varia.}

\section{Synonymy.}

Columbella varia Sowb. in Proc. Zool. Soc. Lond. p. 116. June 1832.

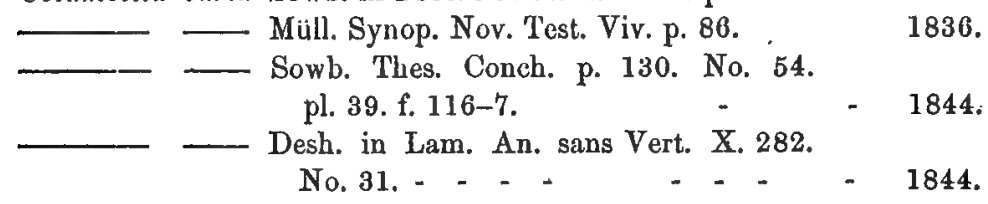

Station.-Under stones; Cuming! Sowerby: also Müller. Under stones; Deshayes.

We found this species in the same situation near low water mark.

Habitat.-Panama; Cuming! Sowerby : also Müller.

Panama; Deshayes: also Jay.

Panama; C. B. A.!

We collected about 380 specimens on the reef.

This species, when deprived of the epidermis, presents in a full suite of specimens a great variety of shades of brown, from orange to blackish brown, for the most part beautifully variegated with spots, and a spiral band of pure white. 
106. Columbella ?

Sp. indet.

We obtained, under stones, at low water mark, on the reef at Panama, two specimens of a species, which appears like a small Conus, but it has stout ribs transverse to the direction. It may be a young Columbella, but it is not the young of any shell known to us.

\section{Ricinula carbonaria ?}

Synonymy.

Ricinula carbonaria Reeve Conch. Icon. pl. 4. f. 22.8

Oct. 1846.

Station.-Under stones at low water mark.

Habitat.-Unknown; Reeve.

Philippines; Jay.

Panama; G. Jewett! Gould MSS.

Taboga and Panama; C. B. A.I

If Dr. Jay's shell is the same as ours, there must be an error in his statement of habitat. We collected 70 specimens, mostly at Taboga and partly at Panama.

\section{Ricinula jugosa. Nov. sp.}

Shell with a rhomboidal outline : mostly dark brown ; tubercles mostly white; with a white fascia next below the periphery of the last whorl; with some of the tubercles partly rufous: with eight or nine very prominent transverse ridges, which are crossed by ten or eleven spiral ridges, of which three or four appear on the spire; with the intersections sharply tuberculous; with fine spiral striæ: apex acute: spire conic: whorls eight or nine, convex, with a moderately impressed suture: aperture rather long: labrum rather sharp, strengthened by the last ridge, which is very long, scalloped by the spiral ridges, with corresponding plaits within: inner lip excavated above, with a few wrinkles above and granules below; canal moderately long. This species is much like a Murex. 
Mean divergence $55^{\circ}$ : length, .94 inch; breadth, .47 inch.

Station.-Unknown.

Flabitat.-Panama; C. B. A.!

Only one specimen was obtained.

\section{Ricinula Reeviana.}

Synonymy.

Buccinum pulchrum Reeve Conch. Icon. pl. 11. f. 80. . Dec. 1846.

Mr. Reeve's specific name of this shell is preoccupied in Ricinula.

Slation.-Under stones, near low water mark.

Habitat.-Gallapago Is.; Cuming $\mid$ Reeve. Panama and Taboga; C. B. A.I

110 specimens were collected.

\section{Cassis abbreviata.}

Synonymy.

Bonanni Recr. III. f. 157.

1684.

List. Conch. t. 1000. f. 65. (Dillw. Ed.)

1688.

Cassis abbreviata Blainv. Fauna Franc. Moll. p. 194.
—— Lam. An. sans Vert. VII. 224. No. 12. Aug. 1822.
— Kiener Iconog. p. 33. pl. 15. f. 31.
lactea , Kiener Iconog. p. 35. pl. 16. f. 35.
- abbreviata Lam. An, sans. Vert. X. 30. No. 12,

Desh. Ed. - - - - - - 1844.

- Reeve Conch. Icon. pl. 8. f. $18 . \quad$ Sept. 1848.

This species, like its analogue, $C$. iriflata, has remarkable varieties of color and of sculpture.

Station.-Unknown.

Habitat.-E Lusitanico litore; Bonanni.

Shores of Portugal, according to Bonanni; Lamarck. 
CASSIS.

Unknown; Kiener.

Acapulco; Reeve.

Panama; C. B. A.!

7 specimens were found. Bonanni is undoubtedly in error.

\section{Cassis coarctata.}

Synonymy.

Cassis coarctata Sowb. Tank. Catal. No. 1826. p. 21. 1825.

Buccinum coarclatum Wood. Ind. Test. Supp. pl. 4. f. 5. 1828.

Cassis coarctata Valenc. in Humb. Rec. Obs. II. 313. 1833.

- - Kiener Iconog. p. 19. pl. 8. f. 15.

27. Desh. Ed. - - - - - 1844.

- — Reeve Conch. Icon. pl. 6. f, 14. Aug. 1848.

Station.-In crevices of rocks; Cuming! Reeve.

Habitat._" We believe it to be a New Zealand shell;" Sowerby.

Unknown; Wood.

Acapulco; Humboldt \& Bonpland! Valenciennes.

The shores of Peru, at Acapulco; Kiener.

The shores of Peru, at Acapulco; Deshayes.

Gallapago Is. ; Cuming I Reeve.

Mazatlan; Melchers I Menke.

Peru, Acapulco; Jay.

Lower California; Major Rich! Gould MSS.

San Juan, in Lower California ; Lt. Green ! Gould MSS, also Museum of Essex Inst.

Taboga; C. B. A.!

We obtained one dead, but nearly perfect specimen.

In copying Kiener's statement, Deshayes has partly, and Dr. Jay has wholly, dropped its absurdity. It does not, however, appear obvious, whether Kiener intended to name two habitats, or to say that Acapulco is in Perul Compare, how. ever, his description of the habitat of Dolium ringens above. 


\section{Oniscia tuberculosa.}

Synonymy.

Oniscia tuberculosa Reeve Conch. Syst. pl. 253. f. 2-4.

1842.

Lam. An. sans Vert. X. 13. No. 2.

1844.

Station.-In clefts of rocks at low water; Cuming! Reeve.

Habitat.-South Seas; Deshayes.

Gallapago Is.; Cuming! Reeve.

Australia; Jay.

San Juan, in Lower California; Lt. Green ! Gould

MSS. ; also Mus. Essex Inst.

Taboga; C. B. A.l

We think Dr. Jay must have been misinformed.

We found 2 specimens, one mature and one young; both were dead, but nearly perfect.

\section{Family-STROMBID 王.}

\section{Conus brunmeus.}

Synonymy.

Conus brunneus Wood Ind. Test. Supp. pl. 3. f. 1.

1828.

Sowb. Proc. Zool. Soc. Lond. p. 18.

Mar. 1834.

May 1836.

Sowb. Conch. III. pl. 57. f. 88. 1841 .

- $\longrightarrow$ Reeve Conch. Icon. pl. 14. f. 72.

June 1843. Lam. An. sans Vert. X. 127. No. 182. 1845 .

—— Kiener Iconog. p. 24. pl. 15. f. 1.

Station.-In clefts of rocks; Cuming ! Sowerby : also Reeve.

Our specimens were found in a similar situation, near low water mark.

Habitat.-Unknown; Wood.

Gallapago Is., Puerto Portrero, and Panama; Cuming! Sowerby: also Reeve: also Müller. 
CONUS.

Panama, and the Gallapagos; Deshayes: also Kiener. Panama; Jay.

Taboga; C. B. A.I

We found 4 specimens. Deshayes's words are, "L'ile de Panama; * * * que l'on rencontre assez fréquemment à Panama et aux Gallapagos." In several instances this author appears to have fallen into the geographical error of supposing Panama to be an island.

\section{Conus gladiator.}

Synonymy.

Conus gladiator Brod. in Proc. Zool. Soc. Lond. p. 55. Apr. 1833. Müll. Synop. Nov. Test. Viv. p. 121. May 1836.

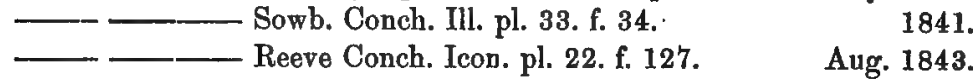

$\begin{array}{lr}- & 1841 . \\ - & \text { Sowb. Conch. Ill. pl. 33. f. 34. }\end{array}$

- Kiener Iconog. p. 25. pl. 15. f. 4. and pl. 100. f. 4.

Station.-In sandy mud in the clefts of rocks; Cuming! Broderip. In soft mud in the clefts of rocks; Cuming! Reeve.

We found this species at low water mark, mostly under stones which were more or less mingled with sand.

Habitat.-Panama; Cumingl Broderip: also Reeve: also Miuller.

Panama; Sowerby : also Kiener : and Jay.

Panama and Taboga; C. B. A.I

We collected 70 specimens.

\section{Conus mahogani.}

Synonymy.

Conus mahogani Reeve Conch. Icon. pl. 22. f. $126 . \quad$ Aug. 1843.

- Reeve in Proc. Zool. Soc. Lond. p. 169. Dec. 1843. - Kiener Iconog. p. 170. pl. 74. f. 3.

Station.-Sandy mud; Cuming I Reeve. JULY, 1852. 
Our specimens were found crawling on a beach of clean and very wet sand, between low water mark and half tide level.

Ilabitat.-Salango; Cuming! Reeve.

Pacific Ocean, shores of Columbia; Kiener.

Salango; Jay.

Taboga; C. B. A.1

We collected 3 living and 14 dead specimens.

\section{Conus nux.}

Synonymy.

Conus nux Brod. Proc. Zool. Soc. Lond. p. 54.

Apr. 1833.

- Müll. Synop. Nov. Test. Viv. p. 120.
- Sowb. Conch. Ill. pl. 32. f. 31.

May 1836.

1841.

—_ - Reeve Conch. Icon. pl. 20. f. 110.

Aug. 1843. Lam. An. sans Vert. XI. 129. No. 185.

1844.

- - Kiener Iconog. p. 47. pl. 11. f. 3. and pl, 102. f. 2.

Station.-Unknown.

Habitat.-Gallapago Is.; Cuming! Broderip: also Reeve: also Müller.

Gallapago Is.; Sowerby: also Deshayes: and Kiener : and Jay.

Taboga; C. B. A.I

We obtained only 2 small specimens.

\section{Conus princeps.}

Synonymy.

Conus princeps Linn. Syst. Nat. I. 713. No. 256. (Ed. 10.) 1758. Linn. Syst. Nat. I. 713. (Ed. 10. alt.) 1760.

\begin{tabular}{lll}
- & Linn. Mus. Ulricæ, p. 552. No. 156. & 1764. \\
\hline & Linn. Syst. Nat. p. 1167. No. 297. (Ed. 12.) & 1767.
\end{tabular}

La Robe Persienne Favanne's D'Argenv. II. 546. pl. xvii. B. 1780. Conus princeps Gmel. in Linn. Syst. Nat. VI. 3378. No. 9. 1788. - regius Chem. Conch. Cab. X. 17. pl. 138. f. 1276.1788. 
Conus princeps Turt. in Linn. Syst. Nat. IV. 313. 1806.

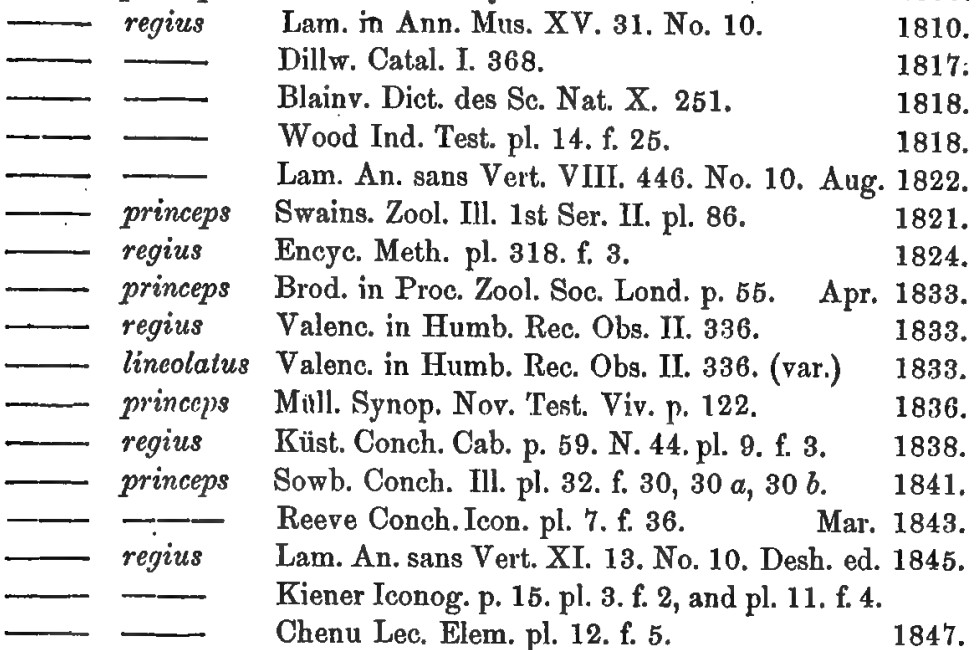

Three varieties of coloring have been found, as follows:-

1. With broad stripes: Lister's fig.; Wood's fig.; Reeve var. a. and fig. 36 a.; Kiener pl. 3. f. 2 ; Chenu's fig. in Lec. Elem. According to Mr. Reeve, this is the Linnæan type.

2. With linear stripes; C. lineolatus Valenc.; Sowb. C. Ill. f. $30 a$., $30 b$.; Reeve var. $b$. and fig. $36 b$.; Kiener pl. 11. f. 4 .

8. Without stripes: Sowb. C. Ill. pl. 30 ? Reeve var. c. and fig. $36 c$.

Station.-In sandy or soft mud in the crevices of rocks; Cum. ing | Broderip : also Reeve.

Our specimens were found under stones at low water.

Habitat.-Unknown; Linnæus : also Gmel. Indies; Turton.

Asiatic Ocean; Dillwyn : also Lamarck : also Bligh Catal.

"Pacific Ocean, shores of Mexico, Bay of Panama;" Kiener. 
Asiatic Ocean, Philippines; Jay.

San Juan, in Lower California; Lt. Green! Gould MSS.

Hab. of Var. 1.-Asiatic Ocean; Wood.

Acapulco; Humboldt and Bonpland! Valenciennes.

Panama; Cuming! Reeve.

Mazatlan; Melchers! Menke.

Hab. of Var. 2.-Acapulco; Humboldt and Bonpland! Valenciennes.

St. Elena and Panama; Cuming | Broderip : also Müller.

Monte Christi and Panama; Sowerby.

St. Elena, Central America, Panama; Cuming! Reeve.

Panama; C. B. A.I

IIab. of Var. 3.-Panama and Monte Christi ; Cuming! Bro. derip.

Monte Christi, Panama; Sowerby.

Monte Christi ; Cuming! Reeve.

Panama; C. B. A.!

We collected 8 specimens of var. 3 , and 1 of var. 2 . It will be observed that there is no original testimony for any habitat out of the Panama zoological province.

\section{Conus purpurascens.}

Synonymy.

Conus purpurascens Brod. in Proc. Zool. Soc. Lond.

p. 54. - - April 1833. Müll. Synop. Nov. Test. Viv. p. 121. May 1836. Sowb. Conch. IIl. pl. 25. f. 13.

1841.

Reeve Conch. Icon. pl. 19. f. $105 . \quad J u l y ~ 1843$.

Lam. An. sans Vẹrt. XI. 134. No.

193. Desh. Ed. - $\quad$ - - - - 1845. 
CONUS.

Panama S7rells.

Conus purpurascens Kiener Iconog. p. 189. pl. 39. f. 2.

and pl. 61. f. 3 .

Station.-Sandy mud in the clefts of rocks; Cuming 1 Broderip: also Reeve.

Our specimens were found under stones at extreme low water mark.

Habitat.-Panama; Cuming! Broderip: also Reeve: also Müller.

Annaa; Sowerby.

San Blas; Irinds!

San Blas; Hinds! Reeve.

Panama; Kiener: also Deshayes.

Panama and San Blas; Jay.

Panama; C. B. A.l

We collected 12 specimens on the reef. Is there not an error in Sowerby's statement? It appears to want confirmation.

A variety (?) differs in being more slender, in having a convex spire and a subovoid outline, with a few distant elevated spiral lines over the whole surface.

\section{Conus regalitatis.}

Synonymy.

Conus regalitatis Sowb. Proc. Zool. Soc. Lond. p. 19. Mar. 1834. \begin{tabular}{llr}
$\square$ & Müll. Synop. Nov. Test. Viv. p. 124. & May 1836. \\
\hline & Sowb. Conch. Ill. pl. 57. f. 87. & 1841. \\
& Reeve Conch. Icon. pl. 40. f. 218. & Jan. 1844. \\
& Lam. An. sans Vert. XI. 133. No. 192. & 1845. \\
\hline & Kiener Iconog. p. 237. pl. 39. f. 3. &
\end{tabular}

Station.-In the clefts of rocks on sandy mud; Cuming! Sowerby : also Reeve.

We found this species under stones at extreme low water.

Habitat.-Real Llejos; Cuming I Sowerby: also Reeve. Real Llejos; Deshayes.

Shores of Peru; Kiener. 
Real Llejos and Panama; Jay.

Panama; C. B. A.I

We collected 9 specimens, one of which exaeeds three inches in length. May not C. achatinus in Menke's catalogue of Ma. zatlan shells be identical with this species? C. achatinus belongs to another and distant zoological province.

\section{Conus regularisis.}

\section{Synonymy.}

Conus regularis Sowb. Conch. Ill. pl. 29. f. 29. pl. 36.<smiles>[134CH3]</smiles>

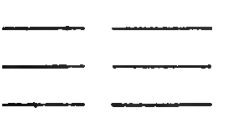

Mr. Sowerby's reference to Z. P. 1841, we are unable to verify.

Station.-Soft mud at the depth of 23 fathoms and at 7 fathoms; Hinds! Reeve.

Habitat.-Gulf of Nicoya and Panama; Hinds! Reeve.

Gulf of Nicoya ; Deshayes.

Philippine Is. ; Kiener.

Mazatlan; Melchers! Menke.

Gulf of Nicoya and Panama; Jay.

Guaymas; Lt. Green! Gould MSS.

Taboga; C. B. A.!

Kiener has doubtless been misinformed.-We found only 1 imperfect specimen of this very rare shell.

\section{Conus vittalus.}

Synonymy.

Knorr Vergn. III Theil. pl. 11. f. 3.

1768.

Conus viltatus Lam. in Ann. Mus. XV. 267. No.63.

1810 .

Dillw. Catal. I. 390. No, 67.

1817.

Wood. Ind. Test. pl. 15. f. 63.

1818.

Lam. An. sans Vert. VII. 470. No. 63. 
STROMBUS.

Conus vitlatus Lam. in Encyc. Meth. pl. 335. f. 3.

- $\longrightarrow$ Reeve Conch. Icon. pl. 14. f. 75.

June 1843.

Desh. ed.
Kiener Iconog. p. 110. pl. 63. f. 5. Cuming I Reeve.

Our specimens were found at low water mark.

Habitat.-Asiatic Qcean; ,Wood: also Lamarck : and Kiener. Bays of Panama and Montija; Cuming! Reeve. Panama; Jay. Taboga; C. B. A.I

The first-named babitat is probably erroneous; it does not appear to be authenticated by any conchological traveller.

We obtained 4 fine living specimens, of which two have an orange tinge, and two have a tinge of brownish purple.

\section{Strombus galea.}

\section{Synonymy.}

Strombus galea Wood Ind. Test. Supp. pl. 4. f. 13; also f. $14 \mathrm{jr}$. - - -

1828.

___ galeatus Gray Descr. Catal. p. 2 (2d Ser. pag.) No. 2. - - - - - - - June 1832.

- Sowb. Thes. Conch. p. 36. No. 54. pl. 10. f. 114.

1842.

$\longrightarrow-\begin{aligned} & \text { Kiener Iconog. p. 5. pl. 2. } \\ & \text { Lam. An. sans Vert. IX. 710. No. }\end{aligned}$ 33. (Desh. ed.) - - - - - - - 1843.

—_ Ducl. in Chenu Ill. Conch. pl. 26, 27. f. 1. 1843.

- Lam. An. sans Vert. III. Pt. 2. p. 751. No. 33. (Desh. ed. tert.) - - 1844.

Küst. Conch. 'Cab. p. 18. pl, 4a. f. 5. pl. 4b. f. 1, 2. -

Reeve Conch. Icon. pl. 13. Nov. 1850.

Station.-On the reefs at low water; Cuming! Reeve. 
Habitat.-Unknown; Wood.

Peru; Gray.

Mazatlan; Kiener : also Duclos.

Sea of California; Deshayes.

Gulf of Nicoya; Cuming! Reeve.

Pacific Ocean; Küster.

Mazatlan; Melchers! Menke.

Gulf of Nicoya \& California; Jay.

Taboga; C. B. A.!

Many fragments only of this shell were seen.

\section{Strombus gracilior.}

Synonymy.

Strombus gracilior Sowb. in Tank. Catal. No. 1792. p. 20.

1825.

Wood Ind. Test. Supp. pl. 4. f. 1.

1828.

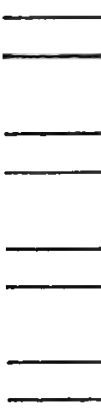
Sowl. Thes. Conch. p. 32. No. 85. pl. 8.

f. 73.

1842.

Kiener Iconog. p. 31. pl. 21. f. 1.

Lam. An. sans Vert. IX. 713. No. 36.

(Desh. ed.) .

Duclos in Chenu Ill. Conch. pl. 17. f. 6, 7. 1843.

Lam. An. sans Vert. III. p. 752. No. 36.

(Desh. ed. tert.)

1844.

Küst. Conch. Cab. p. 36. pl. 4a, f. 6, 7.

1845.

Reeve Conch. Icon. pl. 16. f. 38.

Jan. 1851 .

Station.-Sandy mud at a depth of from 6 to 10 fathoms; Cuming ! Reeve.

Habitat.-Unknown; Wood: also Duclos.

South Seas; Sowerby.

Shore of California; Kiener : also Küster.

Seas of California; Deshayes.

St. Elena \& Panama, Central America; Cuming! Reeve.

Mazatlan; Melchers! Menke.

California \& Tahiti ; Jay. 
STROMBUS.

La Paz; Lt. Green I Gould MSS.; also Mus. Essex Inst.

Taboga; C. B. A. 1

We obtained only 1 dead, but nearly perfect specimen. Mr. Reeve's statement is an example of a common ambiguity. The phraseology implies that St. Elena and Panama are in Central America; but neither place being in that country, the question arises, whether Central America is named as a third locality. Looking over the habitats mentioned by English, and French, and German authors, many such examples occur: and in view of the acknowledged superiority of Europeans in all departments of science, such geography is exceedingly perplexing to an American.

If the locality Tahiti, mentioned by Dr. Jay, can be authenticated, it will be a very important fact of distribution.

\section{Strombus granulatus.}

\section{Synonymy.}

Strombus granulatus Swains. in Bligh Catal App.p. 8. May 1822.

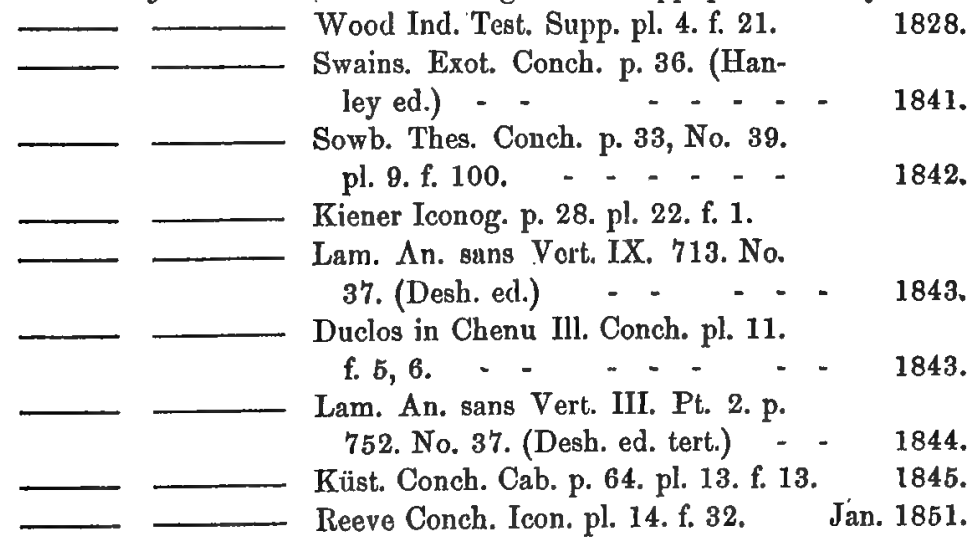

Slation.-In sandy mud at the depth of from 6 to 8 fathoms; Cuming! Reeve. 
Habitat._Unknown: Wood: also Sowerby.

Seas of India ; Kiener : also Duclos : also Küster.

Seas of India, according to Kiener; Deshayes.

St. Elena \& Gallapago Is; Cuming I Reeve.

Mazatlan; Melchers! Menke.

Central America; Jay.

La Paz; Lt. Green 1 Mus. Essex Inst.

Panama; E. Jewett! Gould MSS.

Taboga; C. B. A.!

We collected 7 dead specimens. We have received a number of specimens from the Sandwich Islands, but cannot vouch for this locality.

\section{Strombus Peruvianus.}

\section{Synonymy.}

Strombus Peruvianus Swains. Zool. Ill. 2nd Ser. No. 39

in Index, No. 1 on plate. - - - 1823.

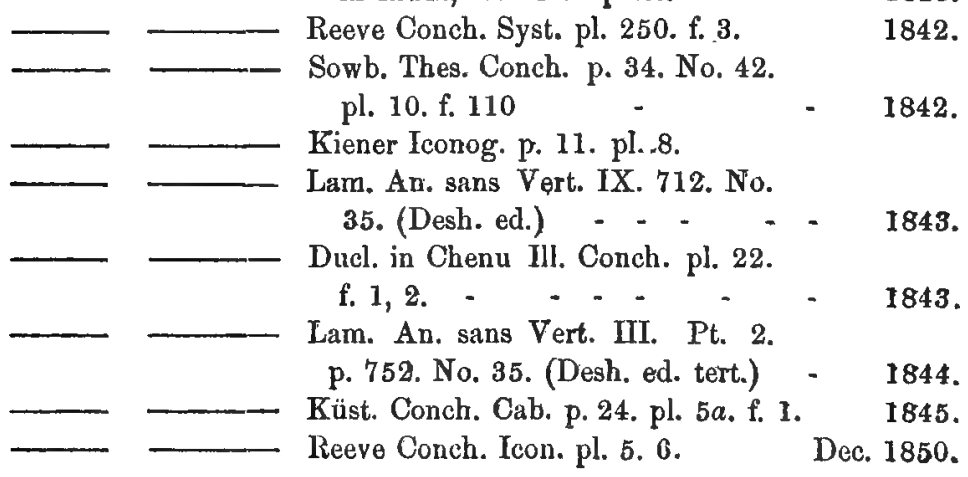

Station.-On the reefs at low water; Cuming! Reeve.

Our specimens were taken on a clean sandy beach at low water. On Dec. 6th (1850) there were many seen alive: but on revisiting the place, Dec. 31 , only 2 or 3 dead shells could be found.

Habitat.-Peru, and near Panama; Swainson.

Unknown; Sowerby. 
TRITON.

Shores of Peru; Kiener: also Deshayes.

"Le Perou et je crois la mer Rouge ;" Duclos.

Bay of Caraccas; Cuming I Reeve.

Peru; Jay.

Taboga ; C. B. A.l

We collected 24 specimens.

Notwithstanding the opinion of Duclos, we are very sceptical of the identity of any Red Sea species with those species which inhabit this continent.

\section{Family-MURICID正.}

\section{Triton Chemmitzii.}

Synonymy.

Argo-buecinum nodosum Chem. Conch. Cab. IV. 98. pl.

131. f. 1255-6. - - - - 1780.

Murex argus var. $\beta$ pdrs. Gmel. in Linn. Syst. 3547. No. 78. 1788.

Triton Chemnitzii Gray in Zool. Beech. Voy. p. 110. 1839.

Fusus Wiegmanni Anton Verzeich. p. 77. 1839.

Cassidaria setosa . Hinds teste Reever

Triton Chemnitaii Reeve Conch. Icon. pl. 11. f, 37. May 1844.

Fusus Wiegmanni Phil. Abbild. II. pl. 2. f. 2. 4. var. 1845.

Triton perforatus Con. in Proc. Acad. Nat. Sc. Phil.

IV. 156. - - - : - Feb. 1840.

Con. in Journ. Acad. Nat. Sc. Phil.

new ser. I. 280. pl. 99. f. 6. var. 1849.

nodosum Mke. in Zeitschr. Malak. p. 189, : 1850.

Station.-In sandy mud, at the depth of 6 fathoms; Cuming ! Reeve.

We found this species under stones at extreme low water mark.

Habitat.-Panama; Cuming ! Reere.

Panama ; Philippi : also Jay.

Lower California or Pera ; Conrad.

Mazatlan; Melchers I Menke.

Panama, and 'l'aboga; C. B. A. 1

We collected 9 specimens. 


\section{Triton constrictus.}

Synonymy.

Triton constrictus Brod. in Proc. Zool. Soc. Lond. p, 5. Jan. 1833.

I- decussatum Valenc. Ilumb. Rec. Obs. II. 300.

_ constrictus Müll. Synop. Nov. Test. Viv. p. 101.

—_ Reeve Conch. Icon. pl. 12. f. 41. May 1844.

Station.-In sandy mud, in from 7 to 10 fathoms; Cuming! Broderip : also Reeve.

Habitat.-Monte Christi, and Xipixapi; Cuming! Broderip: also Reeve: also Müller.

Acapulco; Humboldt and Bonpland! Valenciennes. (Triton decussatum.)

Panama; C. B. A. 1

We were indebted to the hermit crabs for 4 specimens.

\section{Triton fusoides. Nov. sp.}

Shell ovate-fusiform, slender: whitish, stained with brown, with a white spiral stripe near the middle of the whorls: with prominent narrow not approximate ribs, about nine on each whorl, crossed by numerous raised fine spiral lines, of which the alternate ones are mostly larger: apex acute: spire conic: whorls eight, convex, with a well impressed suture: aperture long subovate : canal short.

Mean divergence about $35^{\circ}$; length .76 inch; breadth .28 inch.

Station.-Unknown.

Habitat.-Taboga; C. B. A.

We obtained only 1 specimen.

\section{Triton gibbosus.}

Synonymy.

Triton gibbosus Brod. in Proc. Zool. Soc. Lond. p. 7. Jan. 183. 
Triton gibbosus Müll. Synop. Nov, Test. Viv. p 102. Reeve Conch. Icon. pl. 14. f. 38. pl. 11. f.

38. var. - - - . - - - June 1844.

Mr. Reeve's reference to Proc. Z. S. 1844 appears to be a misprint.

Station.-Coarse sand at the depth of 7 fathoms; Cuming! Broderip : also Reeve.

Habitat.-Panama, and Monte Christi; Cumingl Broderip: also Reeve.

Panama; C. B. A. 1

We were indebted to the hermit crabs for 5 specimens.

\section{Triton Ifgnarius.}

\section{Synonymy.}

Triton lignarius Brod. in Proc. Zool. Soc. Lond.p. 5.

Jan. 1833.

Müll. Synop. Nov. Test. Viv. p. 101.

May 1830.

-......... Reeve Conch. Icon. pl. 13. f. 40.

June 1844.

Hinds in Voy. Sulph. Moll. p. 12. pl. 4.

f. 15. 16. - - - - - - - 1844.

Station.-Sandy mud at a depth of from 7 to 12 fathoms; Cuming ! Broderip: also Reeve.

Sandy mud 7 fathoms; Hinds!

Habitat.-Puerto Portrero, and Panama; Cuming ! Broderip: also Müller.

Puerto Portrero, St. Elena, and Panama; Cuming ! Reeve.

Monte Christi ; Hinds !

Mazatlan; Melchers! Menke.

Panama; Jay.

Panama; C. B. A. !

We obtained one small but perfect specimen of this very elegant species. The varix at the dabrum is enormously developed. The shell was occupied by a hermit crab. 


\section{Triton vestitus.}

\section{Synonymy.}

Triton vestitus Minds in Proc. Zool. Soc. Lond. p. 21.

Feb. 1844. Reeve Conch. Icon. pl. 20. f. 101.

Aug. 1844. Minds in Voy. Sulpl. Moll. pl. 4. f. 1. 2.

1844.

Station.-Among the rocks on the shore; Hinds !-copied by Reeve.

Our specimens were obtained under stones near low water mark.

Habitat.-Real Llejos, Gulf of Nicoya, and Bay of Honda; Hinds! copied by Reeve.

Taboga; C. B. A.I

We obtained 4 specimens of this beautiful species.

Triton Vestitus? VAR. SENIOR.-We found also near Panama a shell which differs but little from the preceding. It is not so deeply colored, and is lengthened by the addition of another whorl, and consequently it has an additional varix. The sculpture of the lower whorls is less prominent; and the shell is distorted.

\section{Ranella calata.}

\section{Synonymy.}

Ranella caelata Brod. in Proc. Zool. Soc. Lond. p. 179. Oct. 1832. \begin{tabular}{llr}
\hline- & Müll. Synop. Nov. Test. Viv. p. 100. & May 1836. \\
\hline & Sowb. Conch. Ill. No. 8. pl. 85. f. 8. & 1841. \\
Reeve Conch. Syst. pl. 241. f. 8. & 1842. \\
\hline semigranosa Kiener (non Lam.) p. 10. pl. 11. f. 2. &
\end{tabular} celata Lam. An. sans Vert. IX. 554. No. 21. (Desh. Ed.) $-1843$.

L Lam. An. sans Vert. III. Pt. 2. p. 697. No. 21. (Desh. ed. tert.) - 1844. - Reeve Conch. Icon. pl. 3. f. $10 . \quad$ July 1844. According to Deshayes and to Reeve, Kiener has fallen into an error in confounding with this species the $R$. semigranosa of 
Lamarck. Is not Deshayes also in error, when he refers Kiener's figures to the Lamarckian species? Deshayes has copied from Kiener's text the reference to pl. II., which is a misprint for pl. XI.

The apex is always eroded, and many are eroded over much of the spire. The individuals differ much in number and in the degree of development of the granules. Some of the shells are from 2 to 2.3 inches long.

Station.-Under stones; Cuming! Broderip. Under stones at low water; Cuming $!$ Reeve. Wo found this species under stones between the low water mark of the neap tides and that of the spring tides.

Habitat.-Panama; Cuming ! Broderip : also Reeve. Panama; Sowerby : also Kiener : and Deshayes: and Jay.

Panama; E. Jewett! Gould MSS.

Panama; C. B. A.I

We collected 190 specimens on the reef.

\section{Ranella nama.}

\section{Synonymy.}

Ranella nana Brod. and Sowb. in Zool. Journ. IV. 376.

1829.

- Sowb. in Proc. Zool. Soc. Lond. p. 51.

June 1841. Sowb. Conch. Ill. No. 6. pl. 85. f. 6.

1841. Reevo Conch. Syst. pl. 241. f. 0.

1842.

- Reeve Conch. Icon. pl. 6. f. 29.

July 1844.

Station.-Coarse sand at the depth of 7 fathoms; Cuming ! Sowerby. Coarse sand at the depth of 10 fathoms; Cuming I Reeve.

Habitat.- "Ad insulam Panama, Philippinarum ;" Cuming 1 Sowerby.

Panama; Sowerby : also Jay.

Panama; Cuming! Reeve. 


\section{Mazatlan; Melchers! Menke. \\ Panama; C. B. A.1}

Mr. Sowerby's statement of habitat, in the Proc. Z. S., is not intelligible. We found two specimens occupied by hermit crabs. One of the shells is perfect and very elegant.

\section{Ranella nitida.}

\section{Synonymy.}

Ranella nitida Brod. in Proc. Zool. Soc. Lond. p. 179. Oct. 1832. \begin{tabular}{c}
\hline- Müll. Synop. Nov. Test. Viv. p. 99. \\
\hline Sowb. Conch. Ill. No. 4. pl. 84. f. 4. \\
Kiener Iconog. p. 9. pl. 2. f. 2. \\
Lam. An. sans Vert. IX. 557. No. 25. \\
(Desh. ed.) - \\
Lam. An. sans Vert. III. Pt. 2. p. 698. \\
No. 25. (Desh. ed. tert.) - -
\end{tabular} May 1836. 1841. 1843. Reeve Conch. Icon. pl. 8. f. 45.

Station.-Under stones; Cuming! Broderip. Our specimens were found under stones near low water mark.

Habitat.-Bay of Caraccas; Cuming! Broderip : also Reeve: also Müller.

Columbia; Sowerby.

Shores of Columbia; Kiener.

West Columbia; Deshayes.

Bay of Caraccas ; Jay.

Panama; E. Jewett! Gould MSS.

Panama; C. B. A.I

We collected 300 specimens.

\section{Ramella plicata.}

Synonymy.

Ranella plicata Reeve Conch. Icon. pl. 7. f. 33.

July 1844. Station,-Unknown. 
MUREX.

Habitat.-Unknown; Reeve. Panama; C. B. A. 1

We collected 6 specimens of this very aberrant species.

\section{Murex dubius.}

Synonymy.

Murex aculeatus Wood (non Lam.) Ind. Test. Supp. pl. 5. f. 19. 1828. $\begin{array}{llr}\text { - dubius } & \text { Sowb. Conch. Ill. No. 119.pl. 61. f. 23. } & 1841 . \\ & \text { Reeve Conch. Icon. pl. 26. f. 116. } & \text { Aug. } 1845 .\end{array}$ 1841. Station.-Under stones near low water mark.

Habitat.-Unknown; Wood.

Panama; Cuming! Sowerby: also Reeve.

Mazatlan; Melchers! Menke.

Panama; Jay.

Panama; C. B. A. 1

Wo collected 72 specimens on the reef. The spines are remarkably acute.

\section{Murex erosus.}

\section{Synonymy.}

Murex erosus Brod. in Proc. Zool. Soc. Lond. p. 174. Müll. Nov. Test. Viv. p. 93.

Oct. 1832. May 1836. Sowb. Conch. Ill. No. 104. pl. 60. f. 16.

- Reeve Conch. Icon. pl. 32. f. 160. Aug. 1845.

Station.-Under stones; Cuming I Broderip : also Reeve.

Our specimens were found under stones near low water mark.

Habitat-Panama; Cuming 1 Broderip : also Sowerby : and Reeve.

$$
\text { Panama; C. B. A. I }
$$

We obtained 2 specimens on the reef. 


\section{Murex radix.}

\section{Synonymy:}

Favanne's D'Argenv, pl. 37. f. D.

Murex radix

Schröt. Einl. Conch. I. 548. No. 17.

1783.

Gmel. in Linn. Syst. Nat. p. 3527 . No. 10. 1788. melanomathos Dillw. Catal. 686, pars.

1817.

radix

Lam. An. sans Vert. VII. 168. No. 36. Aug. 1822.

Swains. Zool. Ill! 2d. ser. pl! 113. (Sub. gen.

Centronotus.) - - - - - - - - 1823.

Schub, et Wagn. Supp. Chem, p. 132. pl.

230. f. 4064-5.

Wodarch Introd. Conch. (4th ed. Front. f: 3. 1831.

Valenc. in Humb. Rec. Obs. II. 299.

Sowb. Conch. Ill. Catal. No. 85.

1841.

Kiener Iconog. p. 60. pl. 37, 38. f: 1 .

Hanley Conch, Book Spec, p. 91.

1842.

Lam. An. sans Vert. IX. 584. No. 36.

(Desh. ed.) - - - - - - - 1843,

Lam. An. sans Vert. III. Pt. 2. p. 707.

No. 36. (Desh. ed, tert.) - - - - - 1844.

Reeve Conch. Icon. pl. 17. f. 69 . June 1845.

Chenu Lec. Elem. p. 198. f. 652 . 1847.

Perhaps to this synonymy we should add Murex ambiguus, Reeve Conch. Icon. pl. 13. f. 51. Mr. Reeve remarks :-"Any modification of structure may, I apprehend, be considered of specific importance, when it is not immediately approached on either side."-Conch. Icon. Murex, pl, 13. Or even if we could find, in a great number of specimens, a dominant type, with only occasional gradations into another type, the former might be considered as of specific value. In this case, the number of varices not exceeding eight, (while in $M$. radix they are said to equal or exceed ten,) the large open flowery fronds, and the elongate form, are supposed by Mr. Reeve to indicate a specific type. But among our shells, the specimens, which have nine varices together with an intermediate form, are much more numerous than those which correspond to the description and 
figure of $M$. ambiguus. So far, therefore, as we can judge from the 100 specimens collected in one locality, the $M$. ambiguus appears to be, not a dominant type, but the extreme limit of variation. It is quite possible, however, that a greater number of specimens collected in various localities would confirm the opinions of Mr. Reeve:

Dr. Menke, in distinguishing $M$. ambiguus from $M$. nigritus, among the shells from Mazatlan, (Zeitschr. fuir Malak. 1850, p. 188,) finds nine varices in his specimens of the former. $M$. radix is not mentioned as occurring among them.

Station.-On mud banks at low water; Cuming: Reeve.

Qur specimens were found in part in the crevices of rocks, but chiefly about stones, where there was more or less of sandy. mud, near low water mark.

Habitat.-East Indian Seas; Dillwyn.

Shores of Acapulco; Humboldt and Bonpland! Lamarck: also Valenciennes.

Acapulco; Say in Catal. Mus.

Shores of Acapulco and of Panama; Kiener.

Bay of Caraccas; Cuming! Sowerby : also Reeve.

Bay of Caraccas; Jay.

Panama; C. B. A.I

We collected 100 specimens on the reef. Two of them weigh 22 ounces each, and one of these is 52 inches long.

Habitat of $M$. ambiguus.-Unknown; Reeve.

Mazatlan; Melchers I Menk̇e.

Panama; C. B. A. 1

Murex nigritus Phil. we were unable to find at Panama.

\section{Murex rectirostris.}

Synonymy.

Murex rectirostris Sowb. in Proc. Zool. Soc. Lond. p. 138. Nov. 1840. Sowb. Conch. Ill. pl. 197. f. 111. 
Station.-Sandy mud at the depth of 11 fathoms; Cuming ! Reeve.

$$
\begin{gathered}
\text { Flabitat.-Xipixapi ; Cuming! Reeve. } \\
\text { Panama; C. B. A. } 1
\end{gathered}
$$

We obtained ouly 1 immature specimen.

\section{Murex recurvirostris.}

\section{Synonymy.}

Murex recurvirostris Brod. in Proc. Zool. Soc. Lond. p. 174. Oct. 1832. Müll. Synop. Nov. Test. Viv. p. $92 . \quad$ May 1836. - Sowb. Conch. Ill. pl. 59. f. 9.

- Reeve Conch. Icon. pl. 19. f. 75.

June 1845.

Station.-Sandy mud at the depth of 9 fathoms; Cuming! Broderip : also Reeve.

Habitat.-Gulf of Nicoya; Cuming! Broderip : also Sowerby : and Reeve : and Müller.

Gulf of Nicoya; Jay.

Panama; C. B.: A.I

We obtained 1 imperfect specimen.

\section{Murex regius.}

Synonymy.

Murex regius Swains. in Bligh Catal. p. 16. No.201 and No. 806. (Spec. non desc.) -

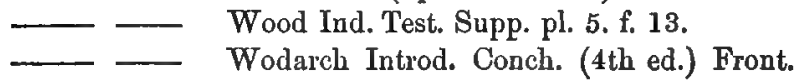

May 1822.

1828.

f. 2.

1831.

- tricolor Valenc. in Humb. Rec. Obs. II. 300. 1833.

- regius Swains. Exot. Conch. p. 5. pl. 15.

— " " " " "Hanley Ed.) 1841.

- Sowb. Conch. Ill. Catal. No. 89. 1841.

— Penny Cyclop. XXII. 55. f. 1842.

$-\quad$ Kiener Iconog. p. 65. pl. 42, 43. f. 1. 
Murex régius Lam. An. sans Vert. IX. 610. No. 80. (Desh. Ed.) - - - - - - -

——— Lam. An. sans Vert. III. Pt. 2. p. 716. No. 80. (Desh. ed. tert.) - - - - Reeve Conch. Icon. pl. 15. f. 59.

Station.-On mud banks at low water; Cuming! Reeve.

Our specimens were found in the crevices of rocks between the low water mark of the spring tides and of the neap tides. We cannot help suspecting some omission in Mr. Cuming's statement of the station of this species and of $M$. radix. Neither species was found by us away from rocks or stones, and we cannot well conceive how, without such shelter, the fronds could be protected from injuries.

Habitat.-Peru; Bligh Catalogue.

South Seas; Wood.

- Acapulco; Humboldt and Bonpland! Valenciennes.

Panama; Cuming I Sowerby: also Reeve.

Western Coast of Central and South America; Penny Cyclopædia.

Shores of Peru; Kiener : also Deshayes.

Panama; Jay: also Mörch.

Panama; C. B. A.I

We collected 18 specimens on the reef. Only a few were taken, because the species is extremely common in collections. We have since regretted the restriction to such a small number, on account of the fine coloring of the exterior and perfect condition of most of these shells. Some of them are also remarkable for size. One specimen is $\mathbf{5 . 3}$ inches long, and 4.2 inches wide.

\section{Murex salebrosus.}

Synonymy.

Murex salebrosus King in Zool. Journ. Lond. V. 347.

1835.

vitulinus Gray (non Lam.) in Zool. Beech. Voy. pl. 33. f. 4,6 . 1839. JULY, 1852 
Murex salebrosms Sowb. Conch. Ml. pl. 65. f. 48.

1841.

- —— Kiener Iconog. p. 121. pl. 47. f. 1.

$\begin{array}{llr}\text { Lam. An. sans Vert. IX. 6f3. Na. 84. } & \\ \text { Desh. ed. - - - - - - } & 1843 . \\ \text { Lam. An. sans Vert. III. Pt. 2. p. 717. } & \\ \text { No. 84. (Desh. ed. tert.) - - } & 1844 . \\ \text { Reeve Conch. Icon. pl. 24.f. 98. } & \text { Aug. 1845. }\end{array}$

Station.-Under stones; Cuming ! Reeve.

We found this species under stones not far.from low water mark.

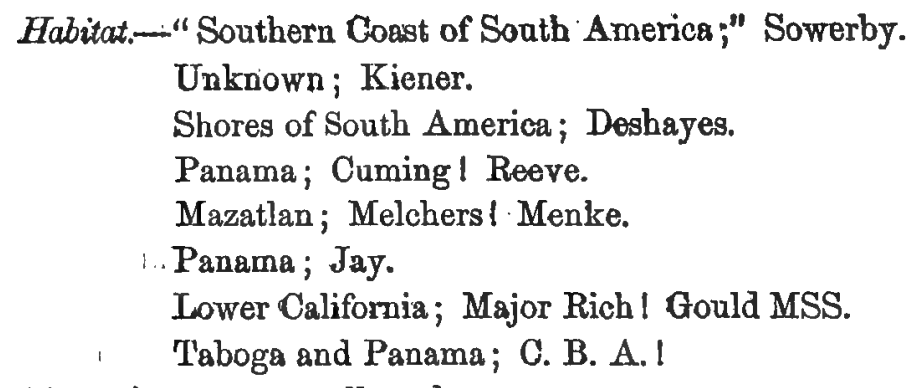

14 specimens were collected.

\section{Murex vibex.}

\section{Synonymy.}

Murex vibex Brod. in Proc. Zool. Soc. Lond. p. 175. Oct. 1832. —_ Müll. Synop. Nov. Test. Viv. p. 94. May 1836. — Reeve Conch. Icon. pl. 34. f. 175. Oct. 1845.

Most of the transverse ridges are simple ridges only, over which the spiral lines are continued without interruption. Occasionally some one ridge appears to be a true varix. The species has been regarded as intermediato between Turbinella and Murex. It seems to be nearer to the former than to the latter genus.

Station.-In sandy mud, at a depth of from 6 to 12 fathoms ; Cuming! Broderip: also Reeve. 
One of our specimens we found alive under a stone. The others were occupied by hermit crabs.

Habitat.-St. Elena and Panama; Cuming! Broderip: also Reeve.

Panama; Jay.

Panama; C. B. A. 1

13 specimens were collected.

\section{Murex vittatus.}

\section{Synonymy.}

Murex viltatus Brod. in Proc. Zool. Soc. Lond. p. 176. Oct. 1832. - Reeve Conch. Iconi pl. 29. f. 140.

Station.-Sandy mud at the depth of 11 fathoms; Cuming! Broderip: also Reeve.

Habitat.-I. of Muerte.Bay, at Guajaquil; Cuming I Broderip: also Reeve.

West Columbia; Cuming in sched.

Panama; C. B. A.1

1 specimen was obtained, which is much larger than Mr. Cuming's specimens.

\section{Pyrula patula.}

Synonymy.

Pyrula patuia Brod. and Sowb. in Zool. Journ. IV. '377.

1828.

- Valencs in Humb. Rec. Obs. II. 281.

1833. also $\mathrm{pL}$ 34. f. 10. and pl. 35. f. 3. young.

1839.

- Kiener Iconog. p. 14. pl. 2. f. 1, 2.

(Desh. ed.)

1843.

- L Lam. An. sans Vert. III. Pt. 2. p. 686. No.

31. (Desh. ed. tert.)

1844.

Cyrtulus — Hinds in Zool. Sulph. Moll. p. 13.

Pyrula - Reeve Conch. Icon. pl. 6. f. 20. 
Deshayes has very aptly remarked of this and of the kindred species, $P$. melongena, that their differences, although not very obvious, derive importance from their constancy; and, we may add, from their restriction each to distinct zoological provinces. One of these types belongs to the Pacific shores of tropical America, and the other to the Caribbean shores. Mr. Reeve, however, has unfortunately assigned the Caribbean species to the "Eastern Seas." It is perhaps unnecessary to say that we have collected plentifully living specimens of $P$. melongena, in Jamaica, where it is a common article of food. Dr. Gould has also received it direct from Cuba, and $\mathrm{Mr}$. Redfield from Carthagena, S. A.

Station.--On mud banks; Cuming! Reeve. Its analogue, $P$. melongena, has a similar station in the West Indies.

- Habitat.-Acapulco; Humboldt and BonplandI Valenciennes. Shores of Mexico; Kiener.

Shores of the Pacific Ocean; Deshayes.

Bay of Caraccas; Cuming! Reeve.

Peru; Cuming in sched.

Mazatlan; Melchers! Menke.

Mazatlan; Lt. Green! Gould MSS. : also Mus. Essex Inst.

Pacific; Jay.

Bay of Panama; C. B. A.I

We saw this species in a large heap of edible Molluscs, near the houses of some natives in Panama. None of the specimens being perfect, we took only one, which is nearly seven inches long.

\section{Ficula ventricosa.}

Synonymy.

Martini III. pl. 66. f. 733.

1777.

Pyrula ventricosa Sowb. in Tank. Catal. No.1614. App. p. 16. 1825. Bulla decussata Wood Ind. Test. Supp. pl. 3. f. 3.

Pyrula ventricosa Kiener p. 27. pl. 12. f. 2.

1828.

Lam. An. sans Vert. IX. 521. No. 29. (Desh. ed.) 1843. 
Fidula iventricosa Chenu. Ill. Conchi pl. :1. f.:1. pl. 2: f. 1. 1843. Pyrula —-Lám: An: sans Vert.III. Pt: 2، p: 686. No. 29.

(Desh. ed. tert:)

Ficula' decussata Reeve Conch.IIcon!' ph. 1. f. .3. : ' Mry, 1847.

'Station.-None of our specimens were taken alive; but it is probable that the species indhabits sands bèlow low water mark.

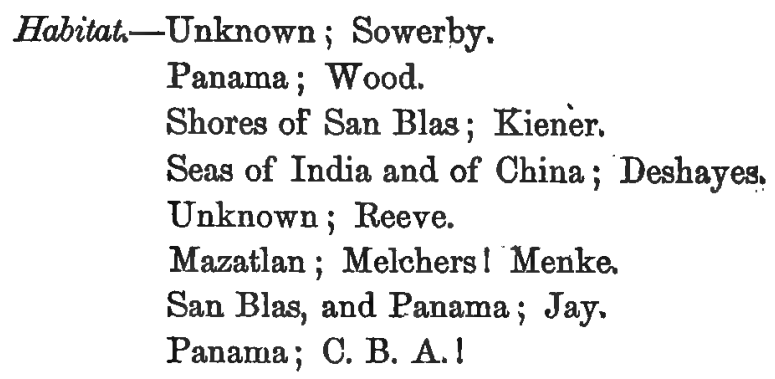

We collected 8 specimens on the sand beach west of Panama.

\section{Fusus' bellus. Nov.'sp.}

Shell rather elongate and regularly fusiform; white, with some reddish brown spots in spiral series, mostly in three series, one above and two next below the middle of the whorls: with, on each whorl, about ten rather narrow prominent ribs, some of which are varicoid, with spiral raised lines, with the intersections nodulous, and spiral strim: apex acute: spire conic: whorls seven, very convex, with a moderately impressed suture: aperture long ovate; canal wide; moderately lengthened.

Mean divergence about $50^{\circ}$; length .44 inch; breadth .21 inch; , length of spire .22 inch.

'Station.-Unknown.

Habitat.-Panama; C. B. A. 1

One,specimen only was obtained.

\section{Fasciolaria gramosa.}

Synonymy.

Fasciolaria granosa Brod, in Proc. Zaol. Soc: Lond. p. 32. Fob. 1832. JULY, 1852. 
Fasciolaria granosa Müll. Synop. Nov. Test. Viv.p. 106.

May 1836.

- Gray in Zool. Beech. Voy. p. 114.

1839.

- Kiener Iconog. p. 15. pl. 5.

Desh. in Lam. An. sans Vert. IX. 437. No.

11. (Desh. ed.) - - - - $\quad-1843$.

Lam. An. sans Vert. III. Pt. 2. p. 656. No.

11. (Desh. ed. tert.) - - - 1844.

Reeve Conch. Icon. pl. 3. f. $6 . \quad$ Oct. 1847.

Station.-On mud banks; Cuming! Broderip. We found only one specimen alive. It was among stones in a muddy place, near low water mark. From the number of imperfect specimens, which we saw occupied by hermit crabs near low water mark, it seemed probable that its usual station was at a lower level.

Habitat.-Panama; Cuming! Broderip : also Reeve : also Müller.

South Pacific; Gray.

Shores of Peru; Kiener.

"L'ile de Panama;" Deshayes.

Panama; Hankey 1 Reeve.

Peru, and Panama; Jay.

Panama; C. B. A.I

We collected 7 specimens.

\section{Turbinella caestus.}

Synonymy.

Turbinella ccestus Brod. in Proc. Zool. Soc. Lond. p. 8. Jan. 1833. Müll. Synop. Nov. Test. Viv. p. 106. May 1836. Reeve. Conch. Icon. pl. 6. f. 34.

Aug. 1847.

Station.-In soft mud among the rocks; Cuming! Broderip : also Reeve. We found it on a sand beach near low water mark.

Habitat.-Bay of Caraccas; Cuming! Broderip: also Reeve: also Müller.

Mazatlan; Melchers! Menke.

Bay of Caraccas; Jay. 


\section{Taboga ; C. B. A. I}

We obtained 1 living and 1 dead specimen.

This species and T. muricata furnish another interesting example of a pair of nearly allied types, of which one inhabits the Pacific shores of tropical America, while the other is a Caribbean species.

\section{Turbinella castanea.}

Synonymy.

Turbinella castanea Gray in Zool. Beech. Voy. p. 114. 1839. Siebold in Wiegm. Archiv. p. 213. acuminata Reere Conch. Syst. pl. 229. f. 2. 1839. castanea Reeve Conch. Icon. pl. 5. f. 26.

Station.-In crevices of rocks; Cuming ! Reeve.

We found this species in the same situation, not far from low water mark.

Habitat.-Pacific Ocean; Gray.

Panama; Cuming ! Reeve.

Panama ; Jay.

Panama; E. Jewettl Gould MSS.

Taboga and Panama; C. B. A.I

We collected 32 specimens, 12 of which were taken alive. Many of them are covered with prominent spiral linear ridges, which are wanting on others. But the number of specimens with intermediate characters is so large as to show that the distinction is not of specific value.

\section{Turbinella cerata.}

\section{Synonymy.}

Murex ceratus Wood Ind. Test. Supp. pl. 5. f. 15.

Turbinella cerala Griff. An. King. Moll. pl. 41. f. 5.

1828.

- Gray in Zool. Beech. Voy. p. 114.

1834.

1839.

- Kiener Iconog. p. 25. f. 16. f. 1.

Station.-Under stones at low water; Cuming! Reeve. 
We found this species in the same situation and in the crevices of rocks.

Habitat.-Unknown'; Wood.

South Pacific; Gray: 'also Jay.

Mazatlan; Kiener.

Gallapago Is. ; Cuming! Reeve.

Taboga and Panama; C.B. A. 1

We collected 12 specimens.

\section{Turbinella rudis.}

Synonymy.

Turbinella rudis Reeve Conch. Icon. pl. 10. f. 51.

Aug. 1847.

Station.-Under stones, and in the crevices of rocks, near low water mark.

Habitat.-Unknown; Reeve.

Taboga; C. B. A.I

We collected 80 specimens.

\section{Tuxbinella spadicea.:}

Synonymy.

Turbinella spadicea Reeve Conch. Icon. pl. 9. f. 44.

Aug. 1847.

Station.-Unknown.

Habitat.-Unknown; Reeve.

Taboga; C. B. A.I

We collected 15 specimens in various states of preservation.

CANCELLAIR:A!-The speeies of this genus being pelagic, we were unable to make any observations on their habits of station. The number of individuals is small as compared with the number of the species obtained. We collected 25 specimens, which belong to 9 species.

154. Cancellaria affinis. Nov: sp.

Shell ovate. fusiform: brown, sometimes -with one or two 
spiral bands of white: with, on each whorl, about thirty narrow prominent transverse ridges more or less inequidistant; with numerous raised spiral lines, of which five are seen on the spire, and which on the last whorl are less prominent and wide than the transverse ridges: apex subacute: spire with the outlines nearly rectilinear: whorls six, convex, with the suture subca. naliculate; last whorl rather large : aperture semiobovate, with long sharp ridges within on the right side: labrum sharp, thickened a little behind the edge, scalloped by both the internal and the external sculpture: columella stout, with three plaits, of which the upper one is lamelliform and very prominent, and the lower one is small and very oblique : canal short: with a small umbilical chink bounded by the raised labrum and a spiral bridge.

Mean divergence about $68^{\circ}$; length 1.05 inch; breadth .65 inch; length of spire .45 inch.

This species is not so densely and finely sculptured as $C$. elegans Sowb., and is less ventricose than C. asperella Lam.

Station.-Unknown.

ITabitat.-Panama; C. B. A. 1

3 specimens were obtained.

\section{Cancellaria clavatula.}

Synonymy.

Cancellaria clavatula Sowb. in Proc. Zool. Soc. Lond. p. 52. Mar. 1832.

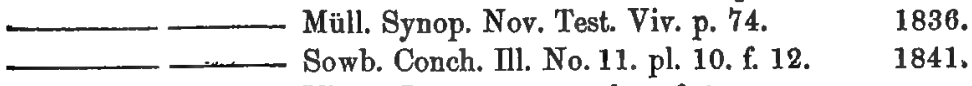

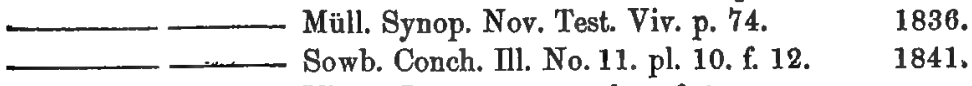

- Kiener Iconog. p. 31. pl. 5. f. 2.

Reeve Conch. Syst. pl. 230. f. 12.

1842.

Lam. An. sans Vert. IX. 416. No. 23.

(Desh. ed.) -

1843.

Lam. An. sans Vert. III. Pt. 2. p. 648.

No. 23. (Desh, ed. tert.)

1844.

Sowb. Thes. Conch. p. 445. No. 20.

pl. 92. f. 13. pl. 95. f. 67 .

1848 。

JULY, 1852 
Station. Sandy mud in 7 fathoms. water ; Cupring! Sowerb.y: Habitát.-Panàma and Paytà; Cuming! Söwerby': also Müllèr."

Bay 'ôf Parama and shore' of Paytat; Kienèr.

Panama and Payta; Deshayes.

Panăma; Jay.

Panäma; C. B. A:! ! '

8 specimens were collected. ${ }^{-\alpha}$.

\section{Cancellaria decussata. $t \leftarrow$.}

Synonymy:

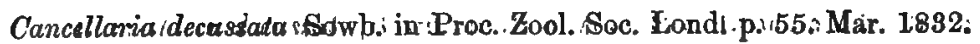
- Müll. Synop. Nov. Test. Viv. p. 787. \% 1836 ، - Sowb. Conch. Ill. No. 8. pl. 9. f. 8. ... ... 1841. Sowb. Thes. Conch. p. 446. No, 24.

$$
\text { pl. 92. f. 3. - - - - } 1848 \text { : }
$$

Station.-Sandy myd, in 10, to 13 fathoms water : Cuming-l. Sowerby.

Habitat.-Panama and Puerto Portrero; Cuming I Sowerby. Panama; Jay.

Panama.CC. B. A.I

2 specimens were obtained.

\section{Cancellaria goniostoma.}

Synoniymy:

Cancellaria goniostoma Sowb. in . Proc... Zool. . Soc. . Lond,... p. 51. 1,- - -- .- Mar. 1832.

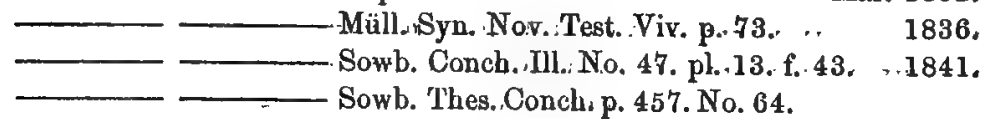
pl. 94. f. 40. is - $\quad$ - 1848 .

Station.-A sandy bottom, in 8. fathoms water; Cuming 1 Sowerby. 


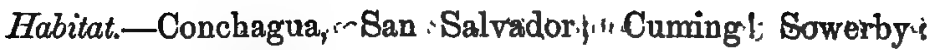
also Miuller: ${ }^{1 !}$ ".

Central America; Jay.

Mazatlan; Melchers! Menke.

Mazatlan ; Itt. Green ! Gould MSSy ri:

Lower California; Major Rich! Gould MSS. :

Taboga; C. B. A.I

We found 1 specimen.

\section{Cancellaria mitrifbrmis:-";}

Synonymy. ircy.:

Cancellaria mitriformis Sowb. in Proc. Zool. Soc. Lond.

$$
\text { p. 51: - - - - - Mar. '7832. }
$$

uniplicata i. i Sowb.r.in Proc. Zool. 'Söc. Lond.....

p. 17;3: - 1. -.- -. $\quad .-\quad$ - Oct. 118821

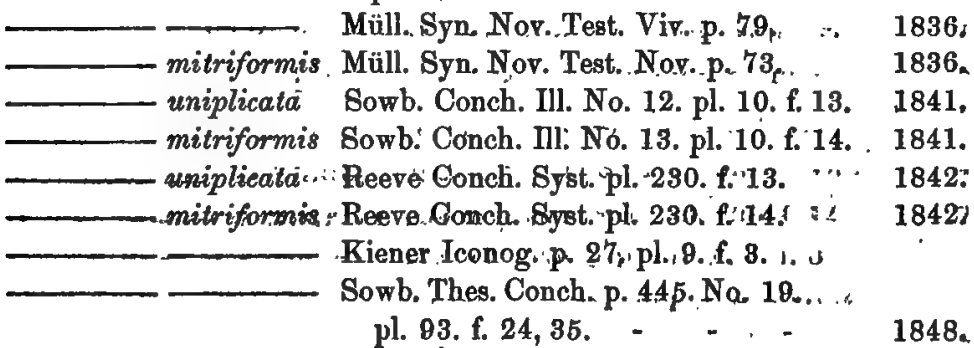

Station.-One specimen of . C. m. was dredged.jn sandy mud Cuming! Sowerb.... Two specimens, of , $C$. us.were dredged in sand at a depth of 10 fathoms; Cuming l,Sowerby .r $\cdots$. .

Habitat.-Panama; Cuming! Sowerby : also Müller.

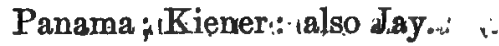

Panama; C. B. A. 1

Two young and 3.maturaspecimens were obtained'nnTwo of the latter of a deep blackish brown, like var. uniplicata.

\section{Cancellaria pulchraiz...}

Synonymy.

Cancellaria pulchra Sowb. in Proc. Zool. Soc. Lond. p. 50. Mar."1832. 
Cancellaria pulchra Müll. Synop. Nov. Test. Viv. p. 72. 1836.

- Sowb. Conch. Ill. No. 39. pl. 13. f. 37. 1841. Sowb. Thes. Conch. p. 451. No. 42. pl. 94. f. 41. - - - - 1848.

Slation.-Sandy bottom in 8 to 10 fathoms water; Cuming 1 Sowerby.

Habitat.-St. Elena; Cuming ! Sowerby: also Miiller.
Taboga; C. B .A.!

Two specimens were obtained.

\section{Cancellaria pygmaa. Nov. sp.}

Shell subovate, short; pale wax color, with minute dark brown dots on the ribs, and dark brown irregular rays on the upper part of the last whorl; with slender prominent ribs, which are only nine in number on the last whorl, but are crowded and numerous on the spire, and which are much developed at the angle of the whorls; with several fine raised spiral lines, which are stouter on the summits of the ribs, and crowded intermediate microscopic striæ: apex subacute: spire with the outlines rectilinear: whorls five, acutely shouldered, with a broad concave area above, moderately convex below the angle, with a well impressed suture: aperture triangular, effuse below: labrum thickened by the last rib; labium thin, elevated: columella with two lamelliform slightly oblique plaits; umbilicus narrow, deep, bounded by an acute angle in the last whorl.

Mean divergence, about $100^{\circ}$; length .33 inch; breadth .25 inch; length of spire .15 inch.

This species is allied to $C$. contabulata Sowb., and $C$. bicolor Hinds.

Station.-Unknown.

Habitat.-Taboga; C. B. A.!

One specimen was found. 
PLEUROTOMA.

Panama Shells.

161. Cancellaria solida.

\section{Synonymy.}

Cancellaria solida Sowb. in Proc. Zool. Soc. Lond. p. 52. Mar. 1832.

- Müll. Synop. Nov. Test. Viv. p. 72. 1836.

- Sowb. Conch. Ill. No. 6. pl. 9. f. 6. 1841. Thes. Conch. p. 440. No. 5. pl. 92. f. $4 . \quad 1848$.

Station.-Eight to ten fathoms, sandy bottom; Cuming I Sowerby.

Habitat.-Real Llejos and St. Elena; Cuming 1 Sowerby: also Müller.

Real Llejos; Jay.

Panama; C. B. A.I

One specimen was found.

\section{Cancellaria tesselata.}

Synonymy.

Cancellaria tesselata Sowb. in Proc. Zool. Soc. Lond. p. 51. Mar. 1832.

- Müll. Synop. Nov. Test. Viv. p. 74. 1836.

Sowb. Conch. Itlust. No. 21. pl. 11. f. 20.1841. Kiener Iconog. p. 32. pl. 8. f. 4.

Sowb. Thes. Conch. p. 447. No. 29. pl. 93.

f. 32.

- 1848.

Station.-Sandy, muddy bottom, in from 7 to 10 fathoms; Cuming I Sowerby.

Habitat.-Bay of Caraccas, St. Elena, and Xipixapi ; Cum. ing I Sowerby : also Müller.

"South Sea; Bay of Caraccas, and St. Elena;" Kiener.

Bay of Caraccas; Jay.

Taboga; C. B. A.I

Two specimens were obtained.

PLEURo'TOMA. Like Columbella, this genus was found to be represented by numerous species; but unlike that genus, JULY, 1852. 
the species were represented by few individuals, at least so far as they could be found without a dredge. A similar abundance of species and scarcity of specimens in this genus occurs in the Caribbean seas. One large species was found; of the others, nearly one half are as small as the Caribbean species: the rest are nearer to an average size as compared with the species which have been described by European authors. Most of the small species are undescribed. If we may judge from the collections made by us in Panama and in Jamaica, and received from Ceylon, it may be conjectured that the undescribed speeies in this genus are as numerous as those which have been described. We do not refer to Kiener's monograph, which contains 60 species : for, including the allied genus Mangelia, nearly 500 species have been described. Probably this is not more than half of the number actually existing.

\section{Pleurotoma aterrima.}

\section{Synonymy.}

Pleurotoma aterrima Sowb. in Proc. Zool. Soc. Lond.

p. 137. - - - Dec. 1833.

- Müll. Synop. Nov. Test. Viv. p. 113. May 1836.

Reeve Conch. Icon. pl. 12. f. 100. May 1848.

Station.-Under stones; Cuming! Reeve.

Our living specimens were found in the same situation at low water mark.

Iabitat.-Monte Christi; Cuming! Sowerby : also Reeve.

West Columbia; Jay.

Panama; C. B. A.!

We collected 14 specimens, most of which were occupied by hermit crabs.

164. Pleurotoma atrior. Nov. sp.

Shell subfusiform: jet black, with a paler translucent spiral stripe below the middle of the whorls: with a spiral series of 
granules next above the suture, and a not very prominent keel above the middle of the whorls; on the last whorl three other keels appear, which are more or less granulated: apex very acute : spire with convex outlines: whorls eleven, angular under the spiral keel, beneath it concave, with an indistinct suture : aperture long, with a rather deep sinus : canal very short, wide. This species has some resemblance to $P$. discors. It must also resemble $P$. Melchersi Menke, Zeitschr. 1851. p. 20.

Mean divergence about $38^{\circ}$; length .8 inch; breadth .28 inch; length of spire .5 inch.

Station.-Unknown.

Habitat._Panama; C. B. A.!

Only 1 specimen was obtained.

\section{Pleurotoma bicamalifera.}

Synonymy.

Pleurotoma bicanalifera Sowb. in Proc. Zool. Soc. Lond.

p. $136 . \quad-\quad$ - - Dec. 1833.

Müll. Synop. Nov. Test. Viv. p.

112. - - May 1836.

Reeve Conch. Icon. pl. 12. f. $103 . \quad$ May 1843.

Station.-Sandy mud at a depth of 10 fathoms; Cuming ! Sowerby : also Reeve.

Habitat.-Shores of Central America; Cuming! Sowerby: also Müller.

Bay of Montija; Cuming ! Reeve.

Taboga; C. B. A.I

We found only 1 specimen.

\section{Pleurotoma collaris.}

Synonymy.

Pleurotoma collaris Sowb. in Proc. Zool. Soc. Lond.

p. 139. - - - - - Dec. 1893. 
Pleurotoma collaris Müll. Synop. Nov. Test. Viv. p. 117. May 1836. - Reeve Conch. Icon. pl. 15. f. 120. July 1843.

Station.-Muddy sand at the depth of 8 fathoms; Cuming! Sowerby : also Reeve.

Habitat.-Bay of Caraccas; Cuming! Sowerby : also Reeve. West Columbia; Jay.

Panama; C. B. A.!

4 specimens were collected.

\section{Pleurotoma concinma. Nov, sp.}

Shell fusiform: white, tinged more or less with reddish brown: with numerous crowded small ribs, which become obsolete near the labrum, and crowded spiral striæ, which are finer on the spire: apex acute : spire with moderately convex outlines: whorls eight, angular along the middle, with a moderately impressed suture: aperture very long and narrow: labrum very much thickened a little behind the edge, with the sinus deep and very near the suture: canal scarcely distinct from the aperture. It resembles $P$. triticea Kiener, and may be a Mangelia.

Mean divergence about $43^{\circ}$; length .42 inch; breadth .17 inch; length of spire .18 inch.

Station.-Unknown.

Habitat.-Panama; O. B. A. 1-1 specimen was obtained.

\section{Pleurotoma corrugata.}

Synonymy.

Pleurotoma corrugata Sowb. (non Kiener) in Proc. Zool. Soc. Lond. p. 137. - - Dec. 1833. turricula Sowb. (non Macgillivray) in Proc.

Zool. Soc. Lond. p. 137. - - Dec. 1838. $\left.\begin{array}{l}\text { corrugata } \\ \text { turricula }\end{array}\right\}$ Müll. Synop. Nov. Test. Viv.p. 114. May 1836. 
Pleurotoma turricula Rcovo Conch. Syst. pl. 233. f. 6.

1842. - Reeve Conch. Icon. pl. 6. f. 49. (non pl. 18. f. 162.) Sowerbyi Reeve Conch. Icon. in "Errata" Feb. 1843. Pleurot. Apr. 1846. Station.-Sandy mud at 10 fathoms depth; Cuming! Sowerby.

Habitat.-Bay of Montija, and Puerto Portrero; Cuming I Sowerby : Müller.

Taboga; C. B. A.I

3 specimens were obtained.

\section{Pleurotoma discors.}

Synonymy.

Pleurotoma discors Sowb. in Proc. Zool. Soc. Lond. p. 137. Dec. 1833. - Müll. Synop. Nov. Test. Viv. p.113. May 1836.

- Reeve Conch. Syst. pl. 235. f. 14.* 1842. - Reeve Conch. Icon. pl. 6. f. 38. - Feb. 1843.

Station.-Coral sand at the depth of 17 fathoms; Cuming ! Sowerby : also Reeve.

Habitat.-I. of Plata; Cuming ! Sowerby : also Reeve. West Columbia; Jay. Panama; C. B. A.1

We were indebted to the hermit crabs for 5 specimens.

\section{Pleurotoma duplicata.}

Synonymy.

Pleurotoma duplicata Sowb. in Proc. Zool. Soc. Lond. p. 138. Dec. 1833. Reeve. Conch. Icon. pl. 9. f. 78. Apr. 1843.

Station-A sandy muddy floor at 10 fathoms depth; Cuming I Sowerby : also Reeve.

* The citation in the Conch. Icon. of fig. 10. in pl. 234 of Conch. Syst, is evidently a misprint for fig. 14 . 
Habitat.-Puerto Portrero and Bay of Montija in Central America; Cuming! Sowerby : also Reeve.

Panama; C. B. A.!

1 specimen was obtained : it is of a blackish brown color, but otherwise is indistinguishable from a specimen received from Mr. Cuming. It is smaller and more slender and finely sculptured than Mr. Reeve's figure.

\section{Pleurotoma excentrica ?}

Synonymy.

Pleurotoma excentrica Sowb. in Proc. Zool. Soc. Lond.

p. 138. - - Dec. 1833. Müll. Synop. Nov. Test. Viv. p. 115. May 1836.

- Reeve Conch. Icon. pl. 7. f. 58. Mar. 1843.

Station.-Coral sand at the depth of 6 fathoms; Cuming! Sowerby : also Reeve.

Habitat.-Gallapago Is. ; Cuming! Sowerby : also Reeve. Panama; C. B. A.!

We found 1 specimen, which probably belongs to this species. It is a little longer than the figure in the Conch. Tcon., and is distorted only in the last whorl: spiral lines cross the ribs only anteriorly.

172. Pleurotoma exigua. Nov. sp.

Shell slender : pale cream color, with very fine brown spiral lines of which the two or three upper ones are single, and the rest are in pairs: with distant obtuse transverse ridges, about six or seven on each whorl, obsolete on the anterior half of the last whorl: apex acute: spire with the outlines moderately convex: whorls six, convex, with a distinct suture: aperture. narrow: labrum thickened by the last ridge a little behind the edge, with a deep sinus near the suture: canal very short.

Mean divergence about $34^{\circ}$; length .175 inch; breadth .06 inch; length of spire .1 inch. 
Station.-Unknown.

Habitat.-Panama; C. B. A.!

1 specimen of this elegant little shell was obtained in the calcareous sand on the shore.

173. Pleurotoma gemmulosa. Nov, sp.

Shell long, subfusiform: brown, with some pale spots: surface densely covered with small transverse and spiral ridges, with the intersections developed into elegantly rounded prominent nodules, except near the end of the last whorl, where the transverse ridges are obsolete : apex acute: spire with the outlines very curvilinear: whorls eight, a little convex, with a moderately impressed suture: aperture very narrow, with a small sinus near the suture: labrum thickened without and within : canal very short.

Mean divergence about $33^{\circ}$; length .22 inch; breadth .08 inch; length of spire .14 inch.

Station.-Unknown.

Habitat.-Panama; C. B. A.1

1 specimen was found.

174. Pleurotoma grandimaculata. Nov. sp.

Shell long, ovate pyramidal : black, with a single spiral series of very large dingy white spots: with excessively minute incremental and spiral striæ, the latter of which are obsolete anteriorly; with a sharp simple spiral keel a little below the suture; a little below the middle of the whorls is a sharp tuberculated keel, which is less developed between the tubercles; these tubercles coincide with the white spots, and on the last whorl are transversely elongated; on the last whorl four or five more spiral linear keels are seen : apex acute: spire conic: whorls ten, concave between the keels, with the suture indistinct; aperture rather narrow; labrum moderately thickened, with the sinus rather deep: labium well developed: canal very short. 
Mean divergence about $38^{\circ}$; length .95 inch; breadth .35 inch; length of spire .62 inch.

Having received from Mr. Cuming specimens of this species labelled $P$. zonulata, we infer that it has been confounded with that species in collections. Mr. Cuming's specimens are said. in the MS. catalogue to have come from the Philippine Is., but as their specific identity with our species is unquestionable, it is probable that the catalogue is erroneous.

Station.-Unknown.

Habitat.-Panama; C. B. A.I

We obtained 1 fresh and 1 faded specimen.

\section{Pleurotoma incrassata.}

Synonymy.

Pleurotoma incrassata Sowb. in Proc. Zool. Soc. Lond.

p. 138. - - - - Dec. 1839.

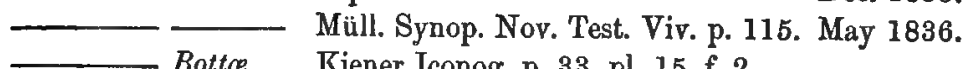
Bottce Kiener Iconog. p. 33. pl. 15. f. 2. incrassata Reeve Conch. Icon. pl. 9. f. 76. Apr. 1843.

Station.-Sandy mud at the depth of 6 to 10 fathoms; Cuming ! Sowerby: also Reeve.

Habitat.-Panama, and Monte Christi ; Cuming! Sowerby. Mazatlan; Botta! (?) Kiener.

Bay of Panama, \&c.; Cuming ! Reeve.

Mazatlan; Melchers! Menke.

Panama; C. B. A. $!$

1 specimen was obtained.

\section{Pleurotoma nigerrima.}

Synonymy.

Pleurotoma nigerrima Sowb. in Proc. Zool. Soc. Lond. p. 197. - - . - - Dec. 1883. 
Pleurotoma cornuta Sowb. in Proc. Zool. Soc. Lond.

p. 136. - - - - - - Dec. 1833. Müll. Synop. Nov. Test. Viv. p. 112. May 1836. nigerrima Müll. Synop. Nov. Test. Viv. p. 113. May 1836. Reeve Conch. Icon. pl. 12. f. $102 . \quad$ May 1843.

Station.-Sandy mud in 6 and 10 fathoms; Cuming! Sowerby : also Reeve.

Habitat.-Panama; Cuming I Sowerby : also Müller.

Bay of Caraccas; Cuming! Sowerby: also Müller. (var. cornuta.)

Panama and Bay of Caraccas; Cuming! Reeve.

Panama; C. B. A. 1

We were indebted to the hermit crabs for 3 specimens.

\section{Pleurotoma obeliscus.}

Synonymy.

Pleurotoma obeliscus Reeve in Proc. Zool. Soc. Lond. p. 110. Oct. 1845. Reeve Conch. Icon. pl. 20, f. 175.

Oct. 1845 .

Station.-Unknown.

Habitat.-Unknown; Reeve.

Panama; C. B. A.I

1 specimen was found.

\section{Pleurotoma olivacea.}

Synonymy.

Pleurotoma olivacea Sowb. in Proc. Zool. Soc. Lond. p. 126. Dec. 1833. Müll. Synop. Nov. Test. Viv. p. 111. May 1836. Reeve Conch. Icon. pl. 4. f. 27.

Feb. 1843、

Station.-In sandy mud at 5 to 12 fathoms; Cuming! Sowerby. From mud in 4 to 7 fathoms depth; Hindsl Reeve.

Habitat.-Salango and St. Elena; Cuming I Sowerby: also Reeve: also Müller. 
Panama, Gulf of Niboya, and western coast of Mexico; Hinds! Reeve.

Panama; Jay.

Panama ; C. B. A.1

8 specimens were obtained.

\section{Pleurotoma pallida.}

Synonymy.

Pleurotoma pallida Sowb. in Proc. Zool. Soc. Lond. p. 137. Dec. 1833. - Müll. Synop. Nov. Test. Viv. p. 113. May 1836. - Reeve Conch. Icon. pl. 16. f. 134. Aug. 1843.

Station-A sandy rnuddy floor at the depth of 13 fathoms; Cuming! Sowerby: also Reeve.

Habitat.-Puerto Portrero; Cuming! Sowerby: also Reeve: also Müller.

Panama; C. B. A. 1

12 specimens in various stages of growth were obtained.

\section{Pleurotoma rigida.}

Synonymy.

Clavatula rigida Hinds in Proc. Zool. Soc. Lond. p. 45. Mar. 1843. - Hinds inVoy. Sulph. Moll. pl. 7. f. 18. Pleurotoma — Reeve Conch. Icon. pl. 25. f. $216 . \quad$ Oct. 1845.

Station.-Unknown.

Habitat.-Panama; Hinds! quoted by Reeve. Panama; C. B. A.I

We collected 20 specimens of this species in some calcareous sand near the sea wall of Panama.

\section{Pleurotoma rudis,}

Synonymy.

Pleurotoma rudis Sowb. in Proc. Zool. Soc. Lond. p. 184. Dec. 1833. 
Pleuntoma rudis Mull Synop. Nov. Test. Vir. p. 109.' ' May 1836. - Reeve Conch. Ioon pl. h. f. 58.

Mar. 1848.

Station.-Under stones; Cuming ! Sowerby: also Reeve: also Müller.

Habitat.-Monte Christi; Cunaing 1. Sowerby; also Reeve: also Müller.

Monte Christi ; Jay.

Panama ; C. B. A.!

- 2 specimens were obtained.

\section{2. - Pleurotoma rustica.}

\section{Synonymy.}

Pleurotoma rustica Sowb.in Proc. Zool Soc. Lond. p. 138. Dea 1833. - Müll. Synop. Nov. Test. Viv. p. 116. May 1836. - thiarella Kiener Iconog. p. 56. pl. 23. f. 2.?

- rustica Reeve Conch. Icon. pl. 11. f. 91. May 1843. Mr. Reeve's reference to Proc. Z. S. 1843, is a misprint for 1833.

Station.-Under stones; Cuming! Sowerby: also Reeve: also Muiller." Wo found it under stones near low water mark.

Habitat.-Xipixapi; Cuming! Sowerby : also Reeve: also Muiller.

West Columbia; Jay.

Panama; C. B. A. I

10 specimens were collected, most of them more strongly striated spirally on the last whorl than is represented in the Conch. Icon.

\section{Pleurotoma striosa. Nov. sp.}

Shell slender: dingy white, with a more or less distinct brown spiral stripe on the last whorl issuing from the upper part of the aperture: with indistinct crowded spiral striø, with ten or twelve very slender ribs on each whorl: apex acute: 
spire with the outlines nearly rectilinear: whorls eight, convex, with a moderately impressed suture: aperture rather narrow: labrum rather sharp, thickened behind the edge by a very stout rib: canal rather wide, very short.

Mean divergence about $33^{\circ}$; length .3 inch; breadth .1 inch; length of spire .2 inch.

Station.-Unknown.

Habitat.-Panama; C. B. A.1

13 specimens were found in the calcareous sand on the shore.

\section{Pleurotoma zonulata.}

\section{Synonymy.}

Pleurotoma cincta Sowb. (non Lam.) in Proc. Zool. Soc. Lond. p. 136. - Dec. 1833. zonulata Reeve Conch. Syst. pl. 234. f. 10. 1842. Feb. 1843.

The name given by Mr. Sowerby was pre-occupied by Lamarck.

Station.-Sand and gravel at a depth of 7 fathoms; Cuming ! Sowerby : also Reeve.

Habitat.-Monte Christi and Xipixapi; Cuming! Sowerby: also Reeve.

$$
\text { Panama; C. B. A.! }
$$

Two specimens were obtained.

Of each of the following species we obtained but one specimen in a more or less imperfect condition. They were found near Panama, mostly in the calcareous sand.

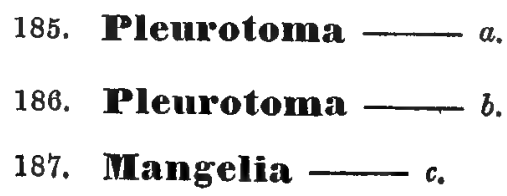


188. Mangelia $-d$.

189. Nangelia -

190. Mangelia $\longrightarrow f$.

\section{Mangelia neglecta. Nov. sp.}

Shell subfusiform: pale brownish red: with, on each whorl, eight or nine prominent curved ribs, and an elevated spiral line on the middle of the whorls, which becomes obsolete on the last whorl; anteriorly with several spiral striæ: apex acute: spire with the outlines moderately convex: whorls seven, rather convex, with a distinct suture: aperture rather narrow, mostly parallel with the axis of the spire: labrum much thickened within and without, with a narrow sinus: canal very short.

Mean divergence about $40^{\circ}$; length .2 inch; breadth .07 inch; length of spire .11 inch.

Station.-Unknown.

Habitat.-Panama; C. B. A.I

We obtained 2 specimens from the calcareous sand at Panama; also other 2, of a more slender variety.

This is one of the many species whose claim to a place in the genus Mangelia will not be universally conceded.

\section{Mangelia sulcosa ?}

Synonymy.

1 Columbella sulcosa Sowb. in Proc. Zoal. Soc. Lond. p. 118. June 1832. - Ducl. in Chenu Ill. Conch. pl. 21. f. 5. 6. - Sowb. Thes. Conch. p. 141. pl. 40. f. 165.

The color of our specimens is a very deep green between the cream-colored ribs, and brownish towards the apex, which is nearly colorless. The "infrd canali distincto" and "interno JUL $\mathrm{X}, 1852$ 
[labio] rugis basilibus nonnullis" Sowb., the well defined sinus of the lip, and the sharp continuous ribs, present a group of characters more characteristic of a Mangelia. We are not, however, perfeetly satisfied of the specific identity of our shell with Mr. Sowerby's.

Station.-We found our specimens under stones at and below the low water mark of neap tides.

- Habitat.-Annaa and Lord. Hood's Island; Cuming ! Sowerby. $\}$ Columbella sulcosa.

Iord Hood's Island; Jay.

Taboga and Panama; C. B. A.I

170 specimens were collected.

\section{Cerithium adustum.}

Synonymy.

Cerithium adustum Kiener Iconog. p. 37. pl. 13. f. 2 non 3.

Lam. An. sans Vert. IX. 313. No. 46.
(Desh. ed.)
Lam. An. sans Vert. III. Pt. 2. p. 611.
No. 46. (Desh. ed. tert.) - -1843.
$\quad-1844$.

There is evidently a transposition, as noticed by Deshayes, Jay, and Menke, in Kiener's references to and names on the plate of his figures of this species and of C. maculosum.

Station.-In wet sand, under stones, at half tide level.

Habitat.-Indian Ocean, Red Sea; Kiener.

Indian Ocean, according to Kiener; Deshayes.

Red Sea; Jay.

Taboga; C. B. A.!

206 specimens were collected. The doubt which Deshayes implies of the accuracy of Kiener's, statement of habitat, must be well founded.

\section{Cerithium assimilatum. Nov, sp.}

Shell very long, conic: very dark brownish red, with some 
irregular linear spots of white on the spiral keels : with three excessively prominent compressed acute nearly equal and equidistant spiral keels, with narrow deep interspaces, which are crossed by microscopic raised lines, with a fourth keal on the periphery of the last whorl, and another anteriorly which is more minute: apex acute: spire with the outlines nearly rectilinear: whorls sixteen to eighteen, planulate, with the suture very indistinct : last whorl very short : aperture ovate : labrum deeply scalloped by the spiral ridges: canal large, very short.

Mean divergence about $18^{\circ}$; length .23 inch; breadth .06 inch; length of spire .19 inch.

This species is allied to $C$. tritineatum Phil. and to $C$. terebellum Ad.

Station.-Under stones, spanges, and marine plants, \&c., near low water mark.

Habitat.-Panama; C. B. A.!

Eight specimens were collected.

\section{Cerithium bimarginatum. Nor. sp.}

Shell long, conic: wax color, dark brown on the upper whorls: with a spiral ridge at each margin of the whorls of the spire and an intermediate raised line; on each whorl with about eighteen transverse small ridges with intersections strongly nodulous; with a simple spiral ridge at the periphery of the last whorl; anteriorly without sculpture: apex very acute: spire with the outlines rectilinear : whorls thirteen, concave, with a well impressed suture; last whorl very short, concave anteriorly, with the periphery angular: aperture subquadrate: columella with a very prominent spiral fold : canal rather short, recurved.

Mean divergence about $20^{\circ}$; length .175 inch; breadth .055 inch; length of spire .14 inch.

Station.-Unknown. 
Habitat,-Panama; C. B. A.!

2 specimens were found.

196. Cerithium famelicum. Nov. sp.

Shell long, ovate conic: dingy white, more or less profusely mottled with irregular brown spots, which are divided by fine white spiral lines; or nearly covered with fine alternating white and brown lines: with a narrow spiral ridge on the middle of the whorls, crossing transverse obtuse ridges, with very prominent acute intersections; with the upper margin of the whorls more or less granulous; anteriorly with two more granulous spiral ridges; surface covered with fine spiral striæ: apex acute: spire with the outlines slightly curvilinear: whorls twelve, moderately convex, with the suture lightly impressed; last whorl short, gibbous on the left, with an anterior concave area : aperture large, obliquely elliptical: labrum advanced in the lower half: labium with a moderately thick deposit and a stout transverse plait above : canal short, oblique.

Mean divergence about $33^{\circ}$; length 1.13 inch; breadth .5 inch; length of spire .75 inch.

In color and sculpture only, this shell has some resemblance to C. maculosum Kr. (C. adustum of Kr.'s plate.)

i Station.-Unknown.

Habitat.-Taboga ; C. B. A.!

17 specimens were collected.

\section{Cerithium gemmatum.}

Synonymy.

Cerithium gemmatum Hinds Voy. Sulph. Moll. pl. 11. f. 5. 6. 1844.

Station.-Sandy mud, in from 2 or 3 to 7 fathoms or upwards; Hinds I 
CERITHIUM.

Habitat.-Panama ; Hinds !

Taboga; C. B. A.!

19 specimens were collected.

\section{Cerithium interruptum ?}

Synonymy.

Perithium interruptum Menke. Zeitsch. Mal. p. 178. for 1850.

Apr. 1851.

Our specimens are, for the most part, much larger than those which Dr. Menke describes. In other respects, they answer to his description as nearly as could be expected in a species with variable characters. Menke's shell is 5.4 lines long, and many of our specimens are 1 inch long.

Station.-On and under rocks and stones, between half tide level and the low water mark of neap tides.

Habitat.-Mazatlan; Melchers I Menke.

Taboga and Panama; C. B. A. I

1100 specimens were collected.

199. Cerithium -. Sp. indet.

This shell is so nearly related to the preceding that it may be a question whether it should rank as a distinct species. It is larger, being 1.2 inch long; and is wholly black, except the eroded apex : it has one series of sharp tubercles, and the spiral granular lines are more prominent and more nearly equal than in $C$. interruptum.

Station.-Like that of $C$. interruptum.

Habitat.-Taboga; C. B. A.1

Thirty specimens were collected.

JULY, 1852. 


\section{Cerithium irroratum.}

\section{Synonymy.}

Cerithium irraratum Gould in Proc. Bost. Soc. Nat. Hist.

III. 119.

Feb. 1849.

Gould Exped. Shells. p. 61.

Feb. 1849.

This species closely resembles $C$. ocellatum Brug., but Dr. Gould informs me that it is his C. irroratum.

Station.-At and above half tide level; mostly in the margin of water left on the rocks by the tide.

$$
\begin{array}{r}
\text { Mabitat.-Unknown; Gould, in Exped. Shells. } \\
\text { Mazatlan; Lt. Green! Gould MSS. } \\
\text { Panama and Taboga; C. B. A.! }
\end{array}
$$

Eight hundred and twenty speoimens were collected.

\section{Cerithium neglectum. Nov. sp.}

Shell long, ovate conic: blackish red, with the apex white : with three prominent spiral ridges on each whorl, of which the upper two are less distant; with prominent transverse ridges, sixteen or eighteen on the last whorl, where they are less robust than on the spire, and which become obsolete on the periphery of the last whorl; with the intersections developed into very prominent elegantly rounded nodules; anteriorly with two additional subgranulous spiral ridges; apex acute: spire with curvilinear outlines: whorls ten, moderately convex, with the suture indistinct; last whorl rather short: aperture obliquely subovate: labrum a little modified by the spiral ridges: canal deep, very short.

Mean divergence about $20^{\circ}$; length .125 inch; breadth .04 inch; length of spire .09 inch.

Station.-Under stones, in old shells, in dead spong'es, \&c., near low water mark. 
CERITHIUM.

Habitat.-Panama; C. B. A. 1

33 specimens were collected.

\section{Cerithium Pacificum.}

Synonymy.

Cerithium Pacificum Sowb. Genera. No. 42. f. 9.

1824.

Humboldti Valenc. in Humb. Rec. Obs. II. 280.

1833.

Kiener Iconog. p. 83. pl. 26. f. 2.

- Pacificum Reeve Conch. Syst. pl, 236. f. 9.

1842.

Kiener ascribes priority to the description by Valenciennes in Humb. Rec. Obs. The second volume of Humboldt's work, in which the Mollusca are described, bears the date 1833.

Station.-Unknown.

Habitat.-Cumana; Humboldt \& Bonpland! Valenciennes.

Cumana; Kiener.

Panama; Jay.

Panama; C. B. A.l

1 specimen only was found.

203. Cerithium pauperculum. Nov. sp.

Shell slender: pale horn color: with several spiral keels, of which five are visible on the spire, with many transverse ridges on the upper whorls, which are reduced to raised lines on the lower whorls, with the intersections slightly granulous; anteriorly the spiral ridges are obsolete: apex acute: spire with the outlines nearly rectilinear: whorls eight, slightly convex, with a moderately impressed suture; last whorl rather long: aperture long, acute above, with a small umbilical chink : canal very short.

Mean divergence about $18^{\circ}$; length .13 inch; breadth .04 inch; length of spire .09 inch.

Station.-Unknown.

Habitat.-Panama; C. B. A.I

2 specimens were found. 


\section{Cerithium pulchrum. Nov. sp.}

Shell rather long, subconic: very dark brownish red, with a yellowish white spiral line on the middle of the whorls : with about forty slender acute ribs on each whorl, which terminate abruptly on the periphery of the last whorl; with very stout varices $240^{\circ}$ distant; with a narrow acute spiral keel, above the middle of the whorls, traversing the ribs and varices: with a few raised spiral lines and many minute spiral striæ, which do not traverse the ribs; anteriorly with crowded coarse spiral striæ: apex acute: spire with the outlines moderately curvilinear : whorls eleven, convex, with a deep suture; last whorl short: aperture large, quadrate-orbicular, broadly effuse above, with a very narrow sinus in place of the canal; labrum and labium continuous, very thick and highly polished.

Mean divergence about $33^{\circ}$; length 1.25 inch; breadth .65 inch; length of spire .82 inch.

This species must closcly resemble C. Mtontagnei Orb. But in Kiener's figure and description, Orbigny's species appears to be destitute of varices. Menke, however, in his specimen of $O$. Montagnei from Mazatlan, finds 48 ribs on the last whorl, but mentions no varices.

Station.-Half buried in muddy sand under bushes at high water mark.

\section{Habitat.-Panama; C. B. A.!}

125 specimens were collected, near the mangrove thicket, $2 \frac{1}{2}$ miles east of Panama.

\section{Cerithium Reevianum. Nov. sp.}

Shell rather long, subconic: dark reddish brown, with a yellowish white spiral line on the middle of the whorls, which is darker between the ribs; with a similar spiral line anteriorly, and another tipping the upper ends of the ribs on the lower whorls: without varices: on each whorl with about twentyfour prominent subacute, not approximate, ribs, which are less 
regular and prominent on the last whorl, on the periphery of which they become obsolete; anteriorly with spiral raised lines, of which one near the periphery is larger: apex acute: spire with the outlines moderately curvilinear: whorls fifteen, convex, with a well impressed suture: aperture large, quadrateorbicular, broadly effuse above, with a narrow sinus in place of the canal: labrum and labium thick, not continuous; labium reflected below.

It resembles Orbigny's figure (not Kiener's) of C. Montagnei; Orbigny's description is too moagre to enable us to identify our species with it, and the figure represents it with flattened approximate ribs, and with several spiral white bands, most of which are wanting on our shell.

Mean divergence about $28^{\circ}$; length 1.55 inch; breadth .66 inch; length of spire 1.04 inch.

Station.-With C.pulchrum, q. v.

Habitat.-Panama; C. B. A.!

190 specimens were collected with $C$. pulchrum.

206. Cerithium validum. Nov. sp.

Shell long, conic: dark reddish brown, with a pale spiral line along the middle of the whorls : rufous on the varices, and white in the aperture: sometimes whitish on the varices, the spiral ridges, and the last whorl: with, on each whorl, about twenty arcuate ridges, which are prominent and rather narrow but not compressed, and which terminate abruptly at the periphery of the last whorl: with stout varices about $270^{\circ}$ distant: with six spiral ridges, of which two next below the suture are small and approximate, and are sometimes replaced by a single ridge: and of which one is partly concealed in the suture: with intermediate minute spiral striæ: anteriorly covered with slightly wrinkled spiral ridges: apex acute : spire with the outlines moderately curvilinear: whorls twelve, convex, with a deep suture: last whorl subangular at the periphery, very short: aperture JULT, 1852 
sub-quadrate, effuse below;' sub-effuse above: labrum produced very far in the lower half, in old shells excessively thickened.

$\therefore$ Mean divergence about $32^{\circ}:$ length, 1.6 inch; breadth, .75 inch; ; length of spire: 1.15 inch.

-. This 'species must closely resemble C. varicosim' Sowb., and C. varicosum Kiener,' which are probably distinet from each other. O. Hegeswichï Phil. is also similar to our shell. (It is to be regretted that Dr. Philippi has not stated which side of Mexico his species inhabits.) Sowerby's shell may be ours. It appears like' a dwarfed variety. 'Orbigny considers' it as the young of the shell which he had from Guayaquil, but speaks of a circular umbilicus.

Station.-With C.pulchrum.

Habitat.-Panama; E. Jewett! Gould MSS.

Panama; C. B. A.!

250 specimens were collected with $C$. pulchrum.

\section{Triphoris alternatus. Nov. sp.}

Shell long, conic, sinistrorsal: blackish red except that in the lower whorls a dingy white spiral stripe occupies the lower twothirds of each whorl: with two stout marginal spiral idges, and a rather smaller intermediate one, which is wanting on the upper whorls; with about twenty-five transverse moderately developed ridges, which terminate at the periphery of the last whorl, with the intersections strongly.nodulous; anteriorly with two additional spiral ridges: apex very acute: spire with the outlines slightly curvilinear: whorls twelve, nearly flat, with an indistinct suture; last whorl short, concave anteriorly: aperture rhombic: canal rather deep, short.

Mean divergence about $30^{\circ}$; length .2 inch; breadth .06 inch; length of spire .155 inch.

: Slation.-Unknown. 
Habitat.-Panama; C. B. A.!

3 mature and 2 young shells were found.

\section{Triphoris inconspicuus. Nov. sp.}

Shell long, ovate fusiform, sinistrorsal: blackish red, fading into a cinereous color: with three spiral equidistant strongly nodulous ridges on each whorl, of which the intermediate one is wanting on the upper whorls, and three or four additional scarcely nodulous ridges anteriorly; with about twenty or twenty-two transverse less prominent ridges on each whorl: apex very acute: spire with curvilinear outlines : whorls twelve, moderately convex, with the suture indistinot; last whorl with the periphery subangular: aperture subrhombic, with a sinus above: labrum much advanced : canal deep, short.

Mean divergence about $22^{\circ} ;$ length .165 ihch; breadth .055 inch; length of spire .13 inch.

Station.-Under stones near low water mark.

Habitat -Taboga and Panama; C. B. A.I

.16 specimens were collected.

\section{Triphoris infrequens. Nov. sp.}

Shell long, conic: blackish red: with three excessively prominent much compressed spiral ridges on the spire, and another on the periphery of the last whorl; with about sixteen or eighteen less prominent transverse ridges on each whorl; anteriorly without sculpture: apex acute: spire with the outlines nearly rectilinear: whorls thirteen, nearly fliat, with the suture indistinct; last whorl very short: aperture subquadrate: labrum scalloped by the spiral ridges : canal rather wide, very short.

Mean divergence about $20^{\circ}$; length .13 inch; breadth .045 inch; length of spire .105 inch.

Station.-Unknown.

-Habitet.-Panama; C. B. A.1

2 specimens. were found. 


\section{Family-LITTORINID \&E.}

\section{0, Turritella Banksii.}

Synonymy.

Turritella Banksii Reeve Conch. Icon. pl. 4. f. 15.

May 1840.

Station.-Sandy mud at the depth of 10 fathoms; Cuming! Reeve.

Between the low water mark of the neap tides and that of the spring tides, this species was found living in the calcareous sand among and under stones.

Habitat.-Panama; Cuming ! Reeve.

Panama; O. B. A.!

On the reef we collected about 350 specimens, one-third of which were taken alive.

This species is remarkable for the diversity of color in different individuals. Some are nearly black and are but slightly variegated; others are mostly white, mottled with a few irregular blackish spots; many are ornamented with a profusion of irregular greyish and blackish spots on a light ground; and a few are brown. Not less than 20 individuals would be required to exhibit fairly this diversity of coloring.

CECUM.-A European type of this extraordinary genus has long been known under the name of Dentalium trachea. In 1849, Mr. Clark of Exmouth, England, described the soft parts in the Ann. and Mag. of Nat. Hist. Mr. C. considered the animal to be kindred to Rissoa. In the Proc. Bost. Soc. Nat. Hist. Oct. 15, 1851, Mr. William Stimpson has described three American species, of which one inbabits Massachusetts, and two inhabit Florida. For some time we have possessed several undescribed species which we collected in Jamaica. Now we offer descriptions of eight species from Panama. It is probable therefore that the genus is well represented on this continent. 
CECUM.

211. Coecum diminutum. Nov. sp.

Shell well arcuated, slender, with the diameter uniform, except near the summit: white: with about 17 stont rings, which are rather distant and are but slightly flattened at the summits, followed by about 10 rings which are small and less prominent: apex lateral, not prominent.

Length .06 inch; breadth .018 inch.

Station.-Unknown.

Habitat.-Panama; C. B. A.1

1 specimen was found.

\section{Cæcum eburneum. Nov, sp.}

Shell rather slender, well arcuated, scarcely widening towards the aperture, slightly contracted at the summit: ivory white: with about 33 broad stout approximate rings with flat summits; with the first 4 to 10 rings and sometimes the last 2 or 3 , very prominent and less approximate, and the rest slightly prominent and closely approximate: apex prominent.

Length .09 inch; breadth .025 inch.

A var. (?) has only 24 rings, of which the last 3 or 4 are prominent, indicating maturity.

Station.-Unknown.

Habitat.-Panama; C. B. A.!

22 specimens were found in the sand.

\section{Crecum firmatum. Nov. sp.}

Shell rather stout, well arcuated, widening towards the aperture, moderately contracted at the summit: ivory white: with about 25 very stout broad prominent not closely approximato rings, with flat summits: apex not very prominent.

Length $.09 \mathrm{inch}$; breadth $.03 \mathrm{inch}$. JULY, 1852 
A variety. (?) is more slender; and has the ribs less prominent.

Station.-Unknown.

... Habitat.-Panama; C. B. A.!

. 85 specimens were collected from the sand.

\section{Cacum-laere. Nov. sp.}

Shell well arcuated, rather stout, of nearly uniform diameter: white : smooth and shining: apex.very prominent.

Length .08 inch; breadth .027 inch.

Var. (?) minus is more slender, with the apex less prominent.

Length .062 inch; breadth .02 inch.

Station.-Unknown.

$\therefore$ Habitat.-Panama; C. B. A.!

2 specimens were found, viz. 1 of each variety.

1. . 10, i215. Coecum Iaqueatum. Nov. sp.

Shell slender, moderately arcuated, with the diameter regularly increasing: white: longitudinally furrowed with about 20 shallow somewhat unequal grooves: apex moderately prominent, lateral.

Length .11 inch; breadth 028 inch.

Station.-Unknown.

Habitat.-Panama ; C. B. A.!

2 specimens were obtained.

216. Cocum monstrosum. Nov. sp.

$\therefore$ Shell.well arcuated; stout in the lower half and very slender in the upper.half, with the transition abrupt, as if the effect of an accident: ivory. white: on the upper part with about 18 rather stout approximate moderately prominent rings with flat 
summits; in the lower part with about 12 very stout prominent not closely approximate rings with flat summits; with 2 or 3 ribs on the middle with intermediate characters: apex prominent.

Length .09 inch; breadth of the upper part .018 inch; breadth of the lower part .03 inch.

This extraordinary shell appears like a monstrosity. It cannot however be a deformed $C$. firmatum, since it is the last half of the shell which resembles that species. If it were the last half which is contracted, it would look more like the effect of an accident. But accidents to mollusks do not, so far as we have seen, cause a greater development of the shell.

7 specimens, agreeing in all the above described characters, establish the species.

Station.-Unknown.

Habitat.-Panama; C. B. A.!

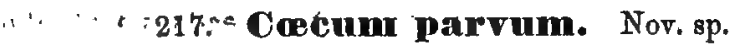

- Shell well arcuated, slender, of nearly uniform diameter: white : with about 15 acute-edged moderately prominent distant rings: apex lateral, prominent.

Length .065 inch; breadth .019 inch.

Station.-Unknown.

Habitat_-Panama; C. B. A.!

1 specimen was obtained.

\section{Coecum pygmaum. Nov. sp.}

Shell well arcuated, slender, of ' nearly? uniform ' diameter: white: with about 23 narrow but very prominent rings with flattened summits : apex lateral, prominent.

Length .06 inch : breadth .018 inch.

- Station.-Unknown. 
Habitat.-Panama; C. B. A.I

2 specimens were found.

CHEMNITRIA.-The following species of this genus, with the exception of $O$. communis and $O$. emarginata, have the axis of the first whorl nearly or quite perpendicular to the axis of the other whorls, constituting a subacute, subtransparent, smooth and colorless apex. This remark, however, cannot yet be applied to C.major, the unique specimen of which has lost the apex.

As in Vitrinella and in some other groups of minute tropical species, the number of individuals is small in proportion to the number of species. The following 12 species are represented by 129 specimens, of which 90 belong to one species, and 21 others belong to 2 species, leaving 9 species represented by only 18 specimens.

\section{Chemnitzia aculeus. Nov. sp.}

Shell conic, very slender : white: with, on each whorl, about seventeen obtuse ribs, which terminate abruptly at the periphery of the last whorl: spire with the outlines rectilinear except near the apex: whorls twelve, moderately convex, with a well impressed suture; last whorl with the periphery subangular: aperture subovate: labrum thin: columella scarcely curved: umbilicus wanting.

Mean divergence about $13^{\circ}$; length .18 inch; breadth .04 inch; length of spire .145 inch.

Station.-Unknown.

Hlabitat.-Panama; C. B. A.I

4 specimens were found in the sand.

\section{Chemnitzia acuminata. Nov. sp.}

Shell fusiform conic: dingy white: with about sixteen or eighteen transverse somewhat oblique ribs, which terminate ab- 
ruptly on the periphery of the last whorl: spire with the out. lines nearly rectilinear: whorls eight, very acutely shouldered above, slightly convex, with a deep suture; last whorl long: aperture subovate, acute at both extremities: labrum thin: umbilicus wanting.

Mean divergence about $23^{\circ}$; length .11 inch; breadth .043 inch; length of spire .07 inch.

Station.-Unknown.

Habilat.-Panama; C. B. A.1

Only 1 specimen was obtained.

\section{Chemmitria aflimis. Nov. sp.}

Shell long, conic: pale .yellowish brown: with, on each whorl, about twenty-four rather slender ribs, which terminate abruptly at the periphery of the last whorl; very smooth anteriorly : spire with the outlines nearly rectilinear: whorls ten, moderately convex, with a well impressed suture; last whorl angular at the periphery: aperture subovate: labrum thin : columella rather stout: umbilicus wanting.

Mean divergence about $18^{\circ}$; length .21 inch; 'breadth .055 inch; length of spire .165 inch.

Most easily distinguished from $C$. striosa (p. 169), by the sculpture of the last whorl.

Station:-Unknown.

Habitat_-Panama; C. B. A.I

2 specimens were found in the sand.

\section{Chemnitzia clathratula. Nor.sp.}

Shell ovate conic, much elongate: white: with, on each whorl, about thirty minute ribs, which gradually become obsolete on the periphery of the last whorl, and which are decussated by spiral raised lines, of which five or six appear on the spire JULY, 1852 
and of which the remainder cover the anterior part of the last whorl : apex very minute: spire with the outlines nearly rectilinear : whorls eight, more or less angular in the upper part, with a well impressed suture; last whorl rather long, with a well rounded periphery: aperture subovate: labrum thin: columella rather stout : umbilicus wanting.

Mean divergence about $16^{\circ}$; length .13 inch; breadth .04 inch; length of spire .1 inch.

Station.-Unknown.

Ilabitat.-Panama; C. B. A.!

10 specimens, in various stages of growth, were collected from the sand.

\section{Chemmitria communis. Nov, sp.}

Shell long, fusiform conic: dingy white: with, on the penult whorl, about twenty-two transverse ridges, and on the last whorl a greater number, which are less prominent, and which become obsolete anteriorly : with spiral ridges, of which four or five are seen on the spire, and which on the last two whorls are as prominent as the transverse ridges, but above are less developed: apex with the axis oblique : spire with the outlines curvilinear: whorls eight, moderately convex, with a well impressed suture: last whorl rather long: aperture ovate, acute above, very broadly effuse below: labrum rather thin, but not sharp : columellar lip well thickened, below reflected over a minute umbilical indentation: columella with one small plait. A large specimen has the following dimensions :-

Mean divergence about $23^{\circ}$; length .165 inoh; breadth .05 inch; length of spire .11 inch.

Station.-Under stones near low water mark.

Habitat.-Panama and Taboga; O. B. A.!

90 specimens were collected. 
" 224. Chemnitzia gracilior. Nov. sp.

Shell very long, conic: very pale yellowish brown : with, on each whorl, about twenty-eight slender ribs, which terminate abruptly just below the periphery of the last whorl: with a well impressed spiral line next behind the anterior termination of the ribs, and a few obsolete spiral striæ: spire with the outlines nearly rectilinear except near the apex: whorls twelve, slightly convex, with a well impressed suture: aperture ovate, acute above: labrum very thin: columella a little curved: umbilicus wanting.

Mean divergence about $13^{\circ}$; length .31 inch; breadth .06 inch; length of spire .255 inch.

Station.-Unknown.

Habitat.-Panama; C. B. A.1

2 specimens were found in the sand.

\section{Chemnitzia major. Nov. sp.}

Shell conic, long: dingy white: with, on each whorl, about twenty-four stout obtuse approximate ribs, which are obsolete anteriorly ; with lightly impressed fine spiral strim over all the surface except the summits of the ribs: spire with the outlines rectilinear: whorls fifteen, moderately convex, with a well impressed suture: aperture subovate: labrum thin : columella nearly straight: umbilicus wanting.

Mean divergence about $17^{\circ}$; length .38 inch; breadth .09 inch; length of spire .31 inch.

Slation.-Unknown.

Habitat.-Panama; C. B. A.1

1 specimen only was found.

220. Chennitaia marginata. Nov. sp.

Shell fusiform cylindric; dingy white: with, on each whorl, 
eleven or twelve very prominent strong compressed ribs : in the interspaces with fine spiral striæ, of which five or six are seen on the penult whorl: apex with the axis oblique: spire with the outlines curvilinear: whorls seven, margined above with spiral compressed ridge, moderately convex, with a well impressed suture: last whorl with the periphery rounded: aperture small, oblique, ovate: labrum thin: labium with a distinct deposit : umbilicus wanting.

Mean divergence about $28^{\circ}$; length .115 inch; breadth .042 inch; length of spire .08 inch.

Station.-Unknown.

Habitat.-Panama; C. B. A. 1

2 specimens were found.

\section{Chemmitzia Pamamensis. Nov. sp.}

Shell long, conic: white : with, on each whorl, about twenty. seven oblique ribs, which become obsolete on the middle of the last whorl, the anterior part of which is very smooth: spire with the outlines nearly rectilinear: whorls twelve, moderately convex, with a well impressed suture : last whorl sub-angular at the periphery: aperture obliquely ovate: labrum thin: columella nearly straight: umbilicus wanting.

Mean divergence about $17^{\circ}$; length .22 inch; breadth :055 inch; length of spire .17 inch.

Station.-In the sand between high water and half tide levels.

Habitat.-Panama; C. B. A. 1

11 specimens were found on the reef.

\section{/ 228. Chemnitzia similis. Nov.sp.}

Shell long, conic: white: with, on each whorl, about twenty. six rather obtuse ribs, which terminate abruptly on the periphery of the last whorl : spire with the outlines nearly rectili- 
near: whorls eleven, convex, with a rather deep suture: last whorl rather long, with the periphery well rounded: aperture subovate: labrum thin : columella straight: umbilicus wanting.

Mean divergence about $17^{\circ}$; length .17 inch; breadth .045 inch; length of spire .13 inch.

Station.-Unknown.

Habitat.-Panama; C. B. A.l

2 specimens were found in the sand.

229. Chemnitzia striosa. Nov. sp.

Shell long, conic: yellowish brown: with, on each whorl, about forty very minute slender ribs, which gradually become obsolete on the periphery of the last whorl ; covered with distinct spiral striæ, of which one a little below the suture and also those which are anterior are larger: spire with the outlines nearly rectilinear: whorls ten, slightly convex, with a well impressed suture: aperture ovate, acute above: labrum thin: columella a little twisted: umbilicus wanting.

Mean divergence about $20^{\circ}$; length .21 inch; breadth .06 inch; length of spire .16 inch.

Station.-Unknown.

Habitat.-Panama; C. B. A.!

1 specimen was found in the sand.

230. Chemmitzia turpita. Nov. sp.

Shell subcylindric in the lower whorls, conic in the upper whorls : white: with, on each whorl, about eighteen sharp compressed slender ribs, which are less prominent on the last whorl, and terminate abruptly at its periphery ; with an impressed spiral line next below the upper margin of the whorls, another at the periphery of the last whorl, and an anterior spiral groove: spire with the outlines curvilinear above the middle, otherwise nearly rectilinear : whorls ten, acutely shouldered, slightly con JULY, 1852. 
vex, with a well impressed suture; last whorl angular at the periphery : aperture subovate : labrum thin : columella straight: umbilicus wanting.

Mean divergence about $23^{\circ}$; length .185 inch; breadth .055 inch; length of spire .14 inch.

Station.-Unknown.

Habitat.-Panama ; C. B. A.!

3 specimens were found in the sand.

231. Cittorima (?) angiostoma. Nov. sp.

Shell obliquely ellipsoidal : dingy white: surface covered with deep regular spiral striæ: apex obtuse : spire rather small with curvilinear outlines: whorls three and one half, very convex, with a distinct suture : aperture subeffuse, nearly semi-elliptical, the inner lip being straight, and well developed : umbilicus conspicuous.

Mean divergence about $85^{\circ}$; length .13 inch; breadth .1 inch; length of spire .055 inch.

The generic character of this species is doubtful. The shell resembles some small species of NARICA.

Station.-Unknown.

Habitat.-Panama; C. B. A.!

3 specimens were found in the sand.

\section{Littorima aspera.}

Synonymy.

Littorina aspera Phil. in Proc. Zool. Soc. Lond. p. 139. Dec. 1845. - Phil. Abbild. II. pl. 4. f. 13. Mur. 1847.

The young are very commonly much angulated near the periphery of the last whorl, as in several other species. They are also more vividly colored. Some extreme examples of this kind might at first be supposed to belong to a distinct species; but the intermediate examples are far more numerous, showing 
that the former are the extreme limits of variation rather than distinct types.

Station.-We found this species on ledges and large fragments of rocks at or above high water mark.

Habitat.-Sitcha, Mexico, and San Salvador; Philippi.

San Salvador; Jay.

Taboga, and Panama; C. B. A.!

We collected 2400 specimens. Dr. Philippi's statement of habitat is "Oceanus Pacificus, Americam borealem alluens; Sitcha; ora Reipublicæ Mexico; S. Salvador in America centrali :" Philippi. It is scarcely credible that this species should have been found in so high a latitude as Sitcha. No original testimony is cited.

Littorina aspera, var., is more slender, and the sculpture is reduced to spiral impressed lines. 33 specimens were collected at Panama.

\section{Littorima atrata. Nov. sp.}

Shell conic when young, subglobular when mature: black, sometimes with a few whitish spots on the last whorl: with spiral keels varying in size and number; usually a strong sharp keel is seen on the periphery of the last whorl and in the suture, and another appears on the upper part of the whorls, with one slightly developed between them; with two or three well developed keels beneath the periphery of the last whorl: apex acute : spire small, eroded in full grown shells, with the outlines moderately curvilinear: whorls four, a little convex, with a well impressed suture; last whorl with an acute periphery in the young, rounded in the mature shell: aperture broadly ovate: labrum well excurved: umbilicus very small. This species is variable in form and in sculpture.

Mean divergence from $65^{\circ}$ to $90^{\circ}$ in different stages of growth; length .08 inch; breadth .06 inch.

Station.-In or near cavities of rocks between half tide and high water levels. 
Habitat.-Panama; C. B. A.!

3,300 specimens were collected.

\section{Littorima comspersa.}

\section{Synonymy.}

Littorina conspersa Phil. Abbild. II. pl. 4. f. 14.

March 1847.

Some individuals, of a more ventricose form and with broader striæ, approximate towards $L$. puncticulata Phil. ; but for the most part the two species are easily distinguished.

Station.-This species was found chiefly on large fragments of rock at high water mark.

Habitat.-Real Llejos; Philippi. Taboga and Panama; C. B. A.I

320 specimens were collected.

\section{Littorima (?) excavata. Nov. sp.}

Shell obliquely ellipsoidal: very dark brown at the apex, in the umbilical region and in the fauces, otherwise pale horn color: with several spiral raised lines, and intermediate very minute spiral striæ; apex subacute: spire small, with the outlines very curvilinear: whorls nearly four, compressed, with a distinct suture; last whorl ventricose: aperture subovate: labrum very sharp, but thickened much a little behind the edge: columella dilated and thickened: region around the umbilicus much excavated: umbilicus small.

Mean divergence about $90^{\circ}$; length .17 inch; breadth 13 inch; length of spire .04 inch.

The generic character of this species is doubtful. It resem. bles a small NARICA.

Station.-Unknown.

Habitat.-Panama; C. B. A.!

1 specimen was found in the sand. 
LITTORINA.

\section{Littorina fasciata.}

\section{'Synonymy.}

Lillorina fasciata Gray in Zool. Beech. Voy. p. 139.

$\therefore 1839$. Siebold in Wiegm. Archiv. p. 206. 1838.

$\longrightarrow$ Phil. Abbild. II. p. 37. pl. 5. f. 1, 2. Apr. 1847.

Station.-This species was found, with $L$. varia, Sowb., on the trunks and branches of small trees, which were growing between half tide and high water levels.

Habitat.-Pacific Ocean? Gray.

Tumbez, Peru; Cuming ! Philippi.

Panama; C. B. A. 1

160 specimens were collected.

\section{Littorina (?) foveata. Nov. sp.}

Shell globose conic: dingy white, with a very broad dark brown spiral stripe occupying the middle of the last and more or less of the upper whorls: with several inequidistant spiral raised lines: apex subacute: spire with the outlines moderately curvilinear: whorls nearly four, subangular, with a distinct suture; last whorl angular below the middle: aperture subovate: labrum very sharp, but much thickened a little behind the edge : columella dilated and thickened: region around the umbilicus much excavated, and forming with the umbilicus a funnel-shaped pit.

Mean divergence about $80^{\circ}$; length .19 inch; breadth .15 inch; length of spire .08 inch.

The generic character of this species is doubtful. It may pos. sibly be a NARICA.

Station.-Unknown.

Habitat.-Panama ; C. B. A.1

2 specimens were found in the sand: 


\section{8.' Littorina (?) megasoma. Nov. sp.}

Shell obliquely ovoid : dingy white : with eight or nine small spiral ridges, of which three are seen on the spire; with very coarse deep regular transverse striæ: apex acute: spire very sinall, with the outlines nearly rectilinear: whorls three, angular, with an excavated suture: last whorl very large and obliquely dilated: aperture subelliptical, with the margin continuous and thin: umbilical region well defined by the anterior spiral ridge, well excavated, and forming with the umbilieus a funnel-shaped pit.

Mean divergence about $135^{\circ}$; length .09 inch; breadth .09 inch; length of spire .035 inch.

This species also is referred to Littorina with much hesitation: it approaches Narica more nearly than any of the species which we have mentioned as resembling that genus.

Station.-Unknown.

Habitat.-Panama; C. B. A.!

1 specimen was found in the sand.

\section{Tittorina parvula?}

\section{Synonymy.}

? Littorina parvula Phil. in Zeitschr. Malak. vol. for 1848.

$$
\text { p. } 149 . \quad-\quad \text { - - M March } 1849 .
$$

If our shell is distinct from Philippi's species, it may take the name of $L$. dubiosa, with the following description.

Shell conoid: blue, whitish next below the suture and anteriorly, with oblique brown bars on the whitish parts; very dark brown inside, spotted with brown and white in the labrum: with several impressed spiral lines, which are more or less indistinct on the spire and on the middle of the last whorl, and of which one next above the angle of the last whorl is deeper : apex subacute : spire with the outlines moderately curvilinear: 
whorls nearly six, a little convex, with a distinct suture; last whorl angular: aperture ovate, acute above, slightly effuse: columellar lip slightly flattened and dilated.

Mean divergence about $55^{\circ}$; length .25 inch; breadth .17 inch.

Some of the more strongly striated and colored individuals resemble the young of $L$. aspera, but the spire is always less acute.

Station.-In the cavities of a rough ledge of rocks, at and above high water mark.

Habilat.-Panama; E. B. Philippi! Philippi.

$$
\text { Taboga; C. B. A.! }
$$

600 specimens were taken at Taboga.

\section{0, Littorima pulchra.}

Synonymy.

Littorina pulchra Sowb. Gen. No. 37. f. 2, 3.

1824. Griff. An. King. Moll. pl. 1. f. 3.

1834.

Turbo pulcher Swains. Malac. p. 207. f. 39.

1840.

Littorina pulchra Reeve Conch. Syst. pl. 222. f. 23.

Lam. An. sans Vert. IX. 208. No. 7.

(Desh. ed.)

1843.

Lam. An. sans Vert. III. Pt. 2. p. 574.

No. 7. (Desh. ed. tert.) - - . 1844

Phil. Abbild. Il. pl. 1. f. 1.

Aug. 1846.

Reevo Elem. Conch. pl. 12. f. 60.

Station.-We found this species on mangrove trees, in a very dense thicket, which was growing from a soil of black unctuous mud a little below high water mark.

Habitat.-Unknown; Deshayes.

"Panama, West coast of Columbia ;" Philippi.

Pacific; Jay.

Panama; C. B. A. ! 
This.species is probably rare. With much labor we obtained 11 specimens in the mangrove thicket, which is about two miles east of Panama. Some of them are fully iequal in size and beauty to the specimen which is figured by Dr. Philippi. The largest is 1.65 inch long and 1.15 inch wide.

\section{Littorima puncticulata.}

Synonymy.

Littorina puncticulata Phil. Abbild. I. pl. 4. f. 15. March 1847.

Station.-On fragments of rocks at high water mark.

Habitat.-Real Llejos; Philippi.

Taboga; C. B. A.!

- 80 specimens were collected.

\section{Littorina varia.}

Synonymy.

Littorina varia Sowb. Gen. No. 37. f. 4.

1824.

- Reeve Syst. Conch. pl. 222. f. 4.

1842 .

Aug. 1846.

Station.-This species was found on the trunks and branches of small trees which were growing between half tide and high water levels.

Habitat.-Panama; Sowerby.

Panama, Guayaquil, Cusma (Peru); Philippi.

"Chiloë (?) nach einer brieflichen Angabe von Herrn Petit;" Philippi.

Peru; Jay.

Panama; C. B. A. 1

300 specimens were collected.

Since this species inhabits the middle regions of the marine zoological province on the west side of tropical America, it is extremely improbable that it should also inhabit a region in so 
remote a latitude as Chiloë. Dr. Philippi has, therefore, with much reason, quoted with doubt the statement of $\mathrm{M}$. Petit.

\section{Rissoa clandestina. Nov, sp.}

Shell long, ovate conic: dingy white: with, on each whorl, about eighteen or nineteen stout prominent compressed ribs, which are continued to the anterior extremity: apex acute: spire with the outlines moderately curvilinear: whorls seven, moderately convex: with a well impressed suture: last whorl rather large: aperture large, oblique, moderately effuse at both extremities: labrum much advanced along the middle, much thickened with a broad varix: umbilicus wanting.

Mean divergence about $30^{\circ}$; length .115 inch; breadth .05 inch; length of spire .07 inch.

Station.-Unknown.

Habitat.-Panama ; C. B. A.!

2 specimens were found.

\section{Rissoa firmata. Nov. sp.}

Shell long, ovate conic: dingy white: with, on each whorl, about twelve very stout, prominent, rather acute ribs, which are continued to the anterior extremity : apex acute: spire with the outlines curvilinear: whorls seven, convex, with a well impressed suture: last whorl rather large: aperture oblique, subovate, effuse at both extremities: labrum well advanced along the middle, thickened with a broad stout rib: umbilicus wanting.

Mean divergence about $30^{\circ}$; length .185 inch; breadth .075 inch; length of spire .13 inch.

Station.-Unknown.

Habitat.-Panama; C. B. A. 1

1 specimen was found in the sand. JULY, 1852. 


\section{Rissoa fortis. Nov. sp.}

Shell long, ovate conic: white: with, on each whorl, about twenty-two to twenty-four stout prominent approximate ribs, which converge at the anterior extremity, where they become very small : apex acute: spire with the outlines curvilinear: whorls ten, slightly shouldered, moderately convex, with a well impressed suture; last whorl ventricose: aperture oblique, ovate, retreating above, deeply effuse ; labrum much advanced in the lower balf, very thick: labium thick: umbilicus wanting.

Mean divergence about $33^{\circ}$; length .29 inch; breadth .12 inch; length of spire .185 inch.

This species resembles $R$. ambigua Gould, and is very different from Rissoina Inca Orb.

Station.--Under stones near low water mark.

Habitat.-Taboga; C. B. A.!

31 specimens were collected.

246. Rissoa (l) inconspicua. Nor. sp.

Shell ovate conic: white : with several spiral ridges, of which two or three are seen on the spire: with about twelve or four. teen transverse narrow ridges, which are obsolete anteriorly: apex subacute: spire with curvilinear outlines: whorls four, very convex, with a deep suture : last whorl rather ventricose, short: aperture orbicular, scarcely effuse: lip well thickened; with a very minute umbilicus. Perhaps this species should have been referred to Cingula.

Mean divergence about $55^{\circ}$; length .045 inch: breadth ,03 inch; length of spire .032 inch.

Station.-Unknown.

Habitat.-Panama; C. B. A.1

1 specimen was obtained. 


\section{Risson infrequens. Nov. sp.}

Shell very long, ovate conic: white: with, on each whorl, sixteen very obtuse slightly elevated indistinct ribs, which are separated only by strix, and a few microscopic revolving striæ: apex subacute: spire with the outlines nearly rectilinear: whorls seven, contracted above, otherwise convex or subangular with a moderately impressed suture; last whorl long, subangu. lar: aperture oblique, subovate, scarcely effuse: labrum much excurved, well thickened: umbilicus wanting.

Mean divergence about $23^{\circ}$; length .24 inch; breadth .075 inch; length of spire .18 inch.

Station.-Unknown.

Habitat.-Panama; C. B. A.I

1 specimen was obtained.

\section{Rigsoa Janus. Nov. sp.}

Shell long, ovate conic: white: anteriorly with fine crowded spiral strix; elsewhere covered with small crowded transverse ribs, which on the last whorl appear merely as transverse striæ becoming obsolete near the periphery: apex acute: spire with the outlines moderately curvilinear: whorls nine, moderately convex; with a lightly impressed suture: aperture large, oblique, moderately effuse below, more deeply effuse above: labrum much advanced along the middle, thickened by a broad stout varix : umbilicus wanting.

Mean divergence about $30^{\circ}$; length .19 inch; breadth .07 inch; length of spire .115 inch.

Station.-Unknown.

Habitat.-Panama; C. B. A.I

2 specimens were found in the sand.

Var. $a$ is larger, being .24 inch long. 


\section{Rissoa notabilis. Nov. sp.}

Shell long ovate-conic: white: with, on each whorl, about fourteen transverse very prominent ribs, which have concave summits; with four spiral keels, of which the upper two are more distant and are seen on the spire on each side of the suture; the transverse ribs are smaller in the parts between the second and third keels, and are obsolete below the third: apex subobtuse, smooth and shining: spire with the outlines rectilinear except near the apex: whorls six, abruptly shouldered, planulate, with the suture subcanaliculate: aperture ovate: umbilicus wanting.

Mean divergence about $24^{\circ}$; length .06 inch; breadth .027 inch.

Station.-Unknown.

Habitat.-Panama; C. B. A.!

1 specimen was found.

250. Rissoa scalariformis; Nov. sp.

Shell elongate, ovate conic: dingy white: with, on each whorl, eleven stout prominent acute compressed ribs, which are continuous on the successive whorls ; covered with microscopic spiral striæ, which ascend the sides of the ribs but are obsolete on their summits: apex acute: spire with the outlines moderately curved: whorls eight, convex, with a well impressed suture: aperture obliquely ovate, effuse above and below: labrum moderately thickened, well excurved and produced along the middle.

Mean divergence about $33^{\circ}$; length .13 inch; breadth .05 inch; length of spire .08 inch.

Station.-Unknown.

Habitat.-Panama ; C. B. A.!

1 specimen was found in sand. 


\section{Rissoa - Sp. indet.}

The sculpture of this shell shows it to be distinct from any others which we have enumerated: but the apex and the lip are both defective in the single specimen found at Panama.

\section{Family-TROCHID \&.}

\section{Cingula (?) inconspicua. Nor. sp.}

Shell ovate fusoid: white : with several spiral ridges, of which four are seen on the penult whorl, and of which the upper two are less prominent; anteriorly the ridges are also less prominent; with transverse ridges decussating the upper spiral ridges and terminating at the third: apex subacute: spire with the outlines a little curvilinear: whorls five, a little convex, with a well impressed suture; last whorl small: aperture small, ovate, acute above: labrum rather thin : labium well developed: umbilical region a little indented.

Mean divergence about $30^{\circ}$; length .065 inch; breadth .035 inch; length of spire .045 inch.

Some authors would refer this species to Rissoa: but the aperture is Turbinoid rather than Melanoid.

Station.-Unknown.

Habitat.-Panama; C. B. A.!

3 specimens were found in the calcareous sand.

\section{Cingula paupercula. Nor. sp.}

Shell conoid : dingy white, sometimes with a pale brown spiral stripe on the middle of the whorls: surface smooth: apex subacute: spire with the outlines nearly rectilinear: whorls five, planulate, with a well impressed suture: aperture broadly ovate: labrum slightly thickened: labium well developed: umbilicus very minute. 
Mean divergence about $33^{\circ}$; length : 085 inch; breadth .05 inch; length of spire .058 inch.

.Station.-Unknown.

Habitat:-Panamia; C.'B. A.!

4 specimens were found in the calcareous sand.

254. Cingula (?) terebellum. Nov.sp.

Shell subcylindric': ' white : with four very' prominent compressed acute spiral keels, of which two are seen op the spire: apex subacute : spire with the outlines moderately ourvilinear : whorls six, slightly çonvex, with an indistinct suture; last whorl small : aperture small, ovate, acute above : labrum thin : labium indistinct: umbilicus wanting.

Mean divergence about $28^{\circ} ;$, length .08 inch; breadth .04 inch; length of spire .055 inch.

Station. Unknown.

Habitat.-Panama ; C. B. A.1

1 specimen was found in the calcareous sand.

\section{Cingula (?) turrita. Nov, sp.}

Shell conic, elongate: white : with numerous prominent compressed transverse ribs, which terminate a little above the suture, where they are crossed by'a spiral raised.line; anteriorly with two or three spiral ridges: apex acute : spire with the outlines nearly rectilinear : whorls six, above abruptly shouldered, planulate, with the suture in a broad groove, which is continued along the periphery of the last whorl : apcrture small, ovate, acute above, very slightly effuse: labrum thin : umbilical region with a very minute indentation.

Mean divergence about $30^{\circ}$; length .08 inch; breadth .033 inch; length of spire .024 inch.

Station.-Unknown. 
Habritat.-Panama; C. B. A.I

1 specimen was found in the sand.

256. Litiopa (8) saxicola. Nov. sp.

Shell long ovate conic : pale horn color, subtransparent : surface covered with deep regular crowded spiral striæ; apex acute: spire with the outlines slightly curvilinear: whorls five, convex, with a well impressed suture; last whorl rather ventricose : aperture broadly ovate, acute above : labrum thin : labium with a distinct deposit: umbilicus wanting.

Mean divergence about $45^{\circ}$; length .14 inch; breadth .075 inch ; length of spire .07 inch.

The generic character of this species is doubtful. The shell has the appearance of a Litiopa, but the station is that of Cingula, to whïch Dr. Gould is inclined to refer it. 'We leave it doubtful, until the soft pàrtś sháll have been examined.

Station.-Under stones at low water mark.

" 'Habitat.-Panana; C.' B. A.!

7 spjecinenens were found orl the reef.

257. Adeorbis (8) abjecta. Nov. sp.

-Shell subglobular? "śmétitnés wholly' of 'y yellowish 'white or wholly" of a díngy black, "or partly' of tach color : with 'several stout spirál raisèd lines' and more or lesss dištinct intermediate strix on the upper part of the whorls :' apex 'subacute': spire sniall, muich éroded in matule shélls : whorls three or more, convex, with a distinct suture; 'last whorl ventricose!' aperture effuse, nearly semicircular, the inner lip being straight: umbilicus small.

Mean divergence about $110^{d} ;$ 'length .1 inch ; breadth .09 inch; length of spire .045 inch.

A. scaber Phil, from Panama, is described as having sublamellar striæ of growth and an acute periphery of the last whorl. Our shell resembles Littorina porcata. Phil. of the Gallapago Is. 
Station.-Unknown.

Habitat.-Panama; C. B. A.!

40 specimens were found in the sand.

VITRINELLA. - The number of species and the scarcity of individuals in this genus of minute shells is remarkable. To the 5 species from Jamaica, of which the genus was originally constituted, we now add 12 from Panama. It will be seen, however, that we have only 60 specimens, of which 24 belong to one species, and 13 to another.

\section{Vitrinella concinna. Nov. sp.}

Shell discoidal: white: with five prominent acute spiral keels, of which one is next below the suture: the second is about equidistant between the suture and the periphery of the last whorl; the third is a little below the periphery; the fourth is on the middle of the lower side of the last whorl; and the fifth is within the umbilicus; with a more or less distinct ridge between the first two keels; with curved transverse elevated lines, which become obsolete on the last half of the last whorl: apex minute, papillary: spire nearly flat: whorls three and one-half: planulate above, with the suture subcanaliculate; last whorl declining near the aperture below the plane of the spire: aperture orbicular, very oblique : lip moderately thickened, slightly angulated by the keels : umbilicus broad and deep.

Divergence about $175^{\circ}$; greatest breadth .062 inch; least breadth .05 inch; height .03 inch.

Station.-Unknown.

Habitat.-Panama; C. B. A. 1

Only 1 specimen was found.

259. Vituinella exigua, Nov. sp.

Shell subdiscoidal : white : on the periphery of the last whorl 
is a keel, which is visible on a small part of the penult whorl, and then runs into the suture; with another somewhat less prominent keel below the periphery, and a third, which is nearly obsolete, around the umbilicus; with not very distinct transverse raised lines, which are most developed between the two lower keels : apex obtuse: spire convex, slightly elevated: whorls nearly three, with a well impressed suture, very convex above so as to simulate a moderately developed carina; last whorl concave on each side of the periphery: aperture orbicular: labrum slightly thickened, modified by the ends of the spiral keels; umbilicus very narrow, deep.

Mean divergence about $170^{\circ}$; greatest breadth .045 inch; least breadth .036 inch; height .021 inch.

Station.-Unknown.

Habitat.-Panama.-C. B. A.1

7 specimens were found in the calcareous sand.

\section{Vitrinella Janus. Nov, sp.}

Shell subdiscoidal: white: with four very narrow acute spiral keels, of which one on the periphery is very prominent, another a little below the periphery is less prominent, and the other two, on the middle of the upper and lower sides, are moderately developed; with minute spiral strim within the lower keel; otherwise with transverse striæ, which are interrupted by the keels : apex prominent; spire moderately elevated: whorls three and one-third, with a distinct suture: aperture orbicular, very oblique: lip slightly thickened, angulated by the keels: umbilicus deep.

Mean divergence $160^{\circ}$; greatest breadth .068 inch; least breadth .06 inch; height .03 inch.

Station.-Unknown.

\section{Habitat.-Panama; C. B. A. I}

1 specimen was obtained. 


\section{Vitrinella minuta. Nov. sp.}

Shell discoidal : dingy white, shining: with excessively minute transverse striæ : apex obtuse : spiré scarcely elevated : whorls nearly three, depressed above, with a well impressed suture; last whorl much depressed, subangular at the periphery : aperture rather large, orbicular: labrum slightly thickened: umbilicus rather deep, nearly covered.

Mean divergence about $170^{\circ}$; greatest breadth .042 inch; least breadth $.036 \mathrm{inch}$; height .017 inch.

Station.-Unknown.

Habitat.-Panama; C. B. A.!

4 specimens were found in the calcareous sand.

\section{Vitrinella modesta. Nov. sp.}

Shell discoidal : dingy white, translucent: with a spiral elevated line next below the suture, and a spiral keel around the umbilicus; with few microscopic spiral striæ about the periphery of the last whorl: apex not prominent: spire a little elevated and regularly convex: whorls three and one-half, with the suture distinct : aperture orbicular: umbilicus deep.

Mean divergence $170^{\circ}$ : greatest breadth .06 inch; least breadth .05 inch; height .028 inch.

Station.-Unknown.

Habitat.-Panama; C. B. A.!

1 specimen was obtained.

\section{Vitrimella Panamensis. Nov, sp.}

Shell subdiscoidal : white : with a stout spiral keel on each side of the periphery of the last whorl, and two others on the lower side of the shell, of which one next to the umbilicus is slightly prominent; with transverse rather distant curved ribs: apex obtuse: spire convex, but little elevated: whorls a little 
more than three, convex above and concave below the middle, with a distinct suture: aperture orbicular: labrum angulated externally by the spiral ridges, a little thickened: umbilicus deep, narrow. $A$.variety has the ridge around the umbilicus well developed.

Mean divergence about $160^{\circ}$; greatest breadth .07 inch ; least breadth .06 inch; height .04 inch.

Station.-Unknown.

Habitat.-Panama ; C. B. A.!

24 specimens were found in the calcareous sand.

\section{Vitrinella parva. Nov. sp.}

Shell subdiscoidal: white: with numerous stout prominent transverse ribs; with, on each side of the periphery of the last whorl, a not very prominent keel, of which the upper one is visible on the spire: apex very obtuse: spire convex, slightly' elevated: whorls three and a half, angular above, concave between the angle and the keel, with the suture not.very distinct; last whorl very large : aperture orbicular, very oblique in consequence of the advance of the labrum above: lip slightly thickened: umbilicus deep, narrow. This species resembles $\nabla$. Panamensis.

Mean divergence about $160^{\circ}$; greatest breadth .047 inch; least breadth .04 inch; height .026 inch.

Slation.-Unknown.

Habitat.-Panama; C. B. A.!

13 specimens were found in the calcareous sand.

\section{Vitrinella perparva. Nov. sp.}

Shell subdiscoidal: white: with a very prominent acute spiral keel on each side of the periphery of the last whorl, and. a less prominent one around the umbilicus; with transverse 
wrinkles, which are obsolete on the upper part of the whorls; apex obtuse: spire flat: whorls nearly three, moderately convex, with a distinct suture; last whorl very large: aperture orbicular, very oblique: lip slightly thickened: umbilicus deep.

Mean divergence $180^{\circ}$; greatest breadth .037 inch; least breadth .031 inch; height .015 inch.

Station.-Unknown.

Habitat.-Panama; C. B. A.!

3 specimens were found in the calcareous sand.

\section{Vitrimella regularis. Nov. sp. .}

Shell subdiscoidal: pearl white: smooth and shining, with an impressed spiral line just below the suture: apex subacute: spire convex, moderately elevated: whorls four and one-half convex, with a distinct suture; last whorl somewhat ventricose: aperture nearly orbicular: lip thin: u̧mbilical region deeply indented.

Mean divergence about $120^{\circ}$; greatest breadth .07 inch; least breadth .06 inch; height .05 inch.

Station.-Unknown.

Habitat.-Panama; C. B. A.!

1 specimen was found in the calcareous sand.

\section{Vitrinella seminuda. Nov. sp.}

Shell discoidal: whito: above with excessively minute striø of growth; beneath covered with spiral strix: apex obtuse: spire scarcely elevated, convex: whorls three, moderately convex, with a distinct suture; last whorl with the periphery subangular: aperture orbicular, very oblique : lip thin : umbilicus narrow, deep. 
Mean divergence about $170^{\circ}$; greatest breadth .062 inch; least breadth .053 inch; height .32 inch:

Station.-Unknown.

$$
\text { Habitat.-Panama; C. B. A.! }
$$

1 specimen was found in the calcareous sand.

\section{Vitrinella tricarinata. Nov. sp.}

Shell subdiscoidal: white : with three prominent spiral keels, one on the periphery of the last whorl, and one on each side of it, of which the upper one is visible on the spire: with some irregular transverse strix : spirally striate within the umbilicus: apex subacute: spire convex, a little elevated: whorls three, depressed above and compressed below the keel, with a distinct suture: aperture oblique, orbicular, angulated by the keels: umbilicus wide and deep.

Mean divergence about $150^{\circ}$; greatest breadth .072 inch; least breadth .065 inch; height .035 inch.

Station.-Unknown.

Habitat.-Panama ; C. B. A.!

1 specimen was found in the calcareous sand.

269. Vitrinella valvatoides. . Nov. sp.

Shell discoidal : whitish, sub-transparent: last whorl with a prominent keel above, which is visible on the spire, with another prominent keel beneath, and a third, less developed, around the umbilicus: spire concave: whorls three, concave above the keel, with a distinct suture : last whorl subangular at the periphery : umbilicus wide and deep.

Greatest breadth .1 inch; least breadth .075 inch; height .04 inch.

Station.-Unknown. 
Habitat.-Panama ; C. B. A.!

3 specimens were found in the calcareous sand.

270. Solarium. Sp. indet. a.

This species closely resembles $S$. granulatum; it differs from $S$. quadriceps Hinds in having the lower series of tubercles not so large as the upper series: the umbilicus is not so open as in S. granulatum.

Station.-Unknown.

Ilabitat.-Panama; C. B. A.!

3 specimens were obtained.

271. Solarium. Sp. indet. $b$.

This species is eminent for the beauty both of its coloring and of its sculpture. It resembles the preceding, and belongs to a group of closely allied species of which several have been described by Dr. Philippi, Mr. Hinds, and others. But few have yet been figured. This also differs from $S$. quadriceps in having the upper girdle larger than the lower one.

Station.-Unknown.

Habitat.-Panama ; C. B. A. 1

3 specimens were obtained.

272. Solarium. Sp. indet. $\boldsymbol{e}$.

This is a small species, finely granulated, of a dark brown color, with the last whorl very convex beneath.

Slation.-Unknown.

Habitat.-Panama; C. B. A.!

We found 6 specimens in the sand.

273. Trochus catenulatus.

Synonymy.

Trochus catenulatus Phil. in Küst. Conch. Cab. p. 110. pl. 18. f. 4. 1847. 
Trochus (Monodonta) catenulatus Menke in Zeitschr. f. Malak. vol. for 1850. p. 173. - - Apr. 1851.

This species belongs to the subgenus Modolus. Its Caribbean analogue is $T$. angulatus $\mathrm{Ad}$.

Station.-Unknown.

Habitat.-Mazatlan; Molchers I Menke.

Taboga; C. B. A.I

23 specimens were collected in various states of preservation.

\section{Trochus coronulatus. Nor. sp.}

Shell conic, moderately elevated, thick: dingy white, with broad reddish brown oblique flammules, with the nodules pale red: with minutely undulated spiral raised lines: anteriorly with four or five larger raised lines: with, on the periphery of the last whorl, two spiral nodulous keels, of which one appears on the spire: with a series of larger nodules on the shouldered margin of the whorls: spire with the outlines moderately curvilinear: apex subacute: whorls six, planulate above the keels, with the suture broadly and deeply canaliculate: aperture nearly orbicular: labrum much advanced in the upper part: columella bidentate: umbilicus one third as wide as the aperture, reaching to the apex.

Mean divergence about $90^{\circ}$; length .55 inch ; greatest breadth .72 inch; least breadth .6 inch.

Station.-Unknown.

Habitat.-Taboga; C. B. A.!

We found 2 specimens.

\section{Trochus Leanus. Nov. sp.}

Shell conic, well elevated: pale yellowish or reddish brown, with broad dark brown oblique flammules; anteriorly somewhat articulated with red and yellowish white in fine con- 
centric lines:- with many elevated granulous spiral lines, of which three larger are next above the suture: spire with the outlines nearly rectilinear: apex acute: whorls nine, planulate or concave next below the suture, very convex or..subangular next above the suture, which is moderately impressed; last whorl subplanulate anteriorly: aperture subquadrate: labrum thin : columella obliquely produced, nearly straight: umbilicus wanting.

Mean divergence about $60^{\circ}$; length .48. inch; greatest breadth .44 inch; least breadth .4 inch.

Slation.-Under stones at low water mark.

Habitat.-Panama; C. B. A.!

7 specimens were collected on the reef. We have named this pretty species in honor of Isaac Lea, Esq., of Philadelphia.

\section{Trochus lima.}

Synonymy.

Trochus lima Phil. in Zeitschr. f. Malak. vol. for 1849.

p. 159.

Mar. 1850.

Phil. in Küst. Conch. Cab. pl. 44. f. 15.

1850.

Station.-Under stones, between the low water mark of the spring tides and that of the neap tides.

Habitat.-Unknown; Philippi.

Santa Barbara; E. Jewett! Gould MSS.

Panama; C. B. A.!

We collected 75 specimens on the reef.

\section{Trochus lividus.}

Synonymy.

Tröchus lividus Phil. in Zeitschr. f. Malak. vol. for 1849,

p. 168. - - - - - - Mar. 1850.

Phil. in Küst. Conch. Cab. pl. 45. f. 8.

1850.

This species belongs to the subgenus Modolus. 
IROCHUS.

Station.-Unknown.

Habitat.-Unknown; Philippi.

Acapulco; E. Jewett $\mid$ Gould MSS.

Taboga; C. B. A.I

We found 3 specimens.

\section{Trochus Panamensis.}

Synonymy.

Trochus Panamensis Phil. in Zeitschr. f. Malak. p. 127. Aug. 1848. Phil. in Küst. Conch. Cab. pl. 44. f. 16.

1850 .

Fresh specimens are very dark colored; but by exposure the shell fades to a red color, as in Kiuster's figure.

Station.-Under stones at low water mark.

Habitat_-Panama; E. B. Philippi! Philippi.

Panama; C. B. A. 1

65 specimens were collected on the reef.

\section{Trochus pellis-serpentis.}

Synonymy.

Trochus pellis-serpentis Wood Ind. Test. Supp. pl. 5. f. 4.

Turbo Valenc. in Humb. Rec. Obs. II. 273. 1833. Trochus strigilatus Phil. Abbild. I. pl. 2. f. 9. Nov. 1843. pellis-serpentis Phil. Abbild. I. Index.

Kist. Conch. Cab. p. 105, pl. 17. f. 4. 1849 ?

Station.-On or under rocks and large stones near half tide level. When the tide retires, these animals crawl around over the surfaces of stones and rocks, beneath which they retire after the surfaces become dry. They are therefore collected most easily when following the tide out. We saw them in the greatest numbers and most active at twilight.

Habitat._Panama; Wood: also Jay. JULY, 1852. 
Acapulco; Humboldt \& Bonpland! Valenciennes. California; Philippi.

West. Coast of Mexico and Central America; Küster.

Taboga and Panama; C. B. A.!

On the reef at Panama we collected 5 specimens; at Taboga we collected 500 .

\section{Trochus reticulatus.}

Symonymy.

Trochus reticulatus Wood Ind. Test. Supp. pl. 6. f. 38. 1828. Kust, Conch. Cab. pl. 14. f. 10.

Station.-Under stones at the low water mark of the neap tides.

Habitat.-Unknown; Wood.

$$
\text { Panama; C. B. A.! }
$$

We collected 600 specimens on the reef.

TURB B.-The difference between the shells of Turbo and of Trochus is of little value. The peculiarities of form, which distinguish these genera, are not only inconsiderable and ill defined, but they are also unaccompanied with corresponding differences in the texture, sculpture, or other characters of the shells, or in the characters of the soft parts of the animals. A great number of : othen genera present in each a difference of outline equal to that which here is made the ground of generic distinction.

The calcareous and the horny opercula present a well defined character. This distinction, however, is not accompanied by corresponding differences in the shells and in the soft parts, and therefore cannot be regarded as of much zoological value. But on account of its convenience we shall for the present distinguish these genera by this eharacter. 
TỬiò.

\section{Turbo Buschii.}

Synonymy.

Trochus Buschii Phil: Abbild. I. pl: 3. f. 3. 4. Küst. Conch. Cab. pl, 32. f. 1.

inermis Kiener Iconog. pl. 14. f. 2.

Jan. 1844.

1849 .

1851.

According to Dr. Philippi, this species is commonly mistaken for $T$. inermis. ' Kiener has figured the Panama shell as $T$. inermis, and a very different species as T. Buschii; v: pl. 31.f. 1 . On account of the solid calcareous operculnm, we have removed the species into Turbo.

Station.-On or under stones between the low water mark of the neap tides and that of the spring tides.

Hrbitat:-Panama; Philippi.

Panama; E. Jewett! Gould MSS.

Panama; C. B. A. I.

We collected 180 specimens on the reef

Dr. Philippi cites Von dem Busch as authority for the habitat, but not, we suppose, as original testimony.

\section{Turbo (z) phasianella. Nov. sp.?}

Shell ovate conoid: color various, mostly red or brown, sometimes uniform, frequently in dark flammules on a light ground, sometimes with spiral darker stripes or series of spots : surface covered with strong spiral striæ: apex subacute: spire conoid, with the outlines moderately curvilinear: whorls five, convex, with a distinct suture : aperture broad ovate, subeffuse : labrum thin: umbilicus very small.

Mean divergence about $64^{\circ}$; length .16 inch; breadth .11 inch; length of spire .08 inch.

Operculum calcareous, very thick and solid. But for the want of a polished surface, this species would have been referrèd to Phasianella. It may be a Trocluus. It may be Littorina phasianella Phil. in Zeitschr: Malak. 1848. p. 149. 
Station.-Unknown.

Habitat.-Panama; C. B. A.!

In the calcareous sand we collected 112 specimens in various stages of growth.

\section{Turbo rutilus. Nov. sp.}

Shell trochiform, well elevated: bright red, with pale, ill defined transverse streaks: with very numerous small very oblique subnodulous ridges on the spire, which are traversed by two or three small spiral grooves on the lower half of the whorls; anteriorly with six to eight narrow deep inequidistant spiral grooves: spire with the outlines nearly rectilinear: apex obtuse (?); whorls (seven?)* planulate, with a distinct suture; last whorl with the periphery angular, subplanulate anteriorly: labrum much advanced above: columellar lip very much dilated and thickened, appressed : umbilicus wanting.

Mean divergence about $70^{\circ}$; length 2.5 inches; greatest breadth 3 inches; least breadth 2.7 inches.

Station.-Unknown.

Habitat.-Panama; C. B. A.!

We obtained 1 specimen on the reef. Fragments of a few others were seen.

\section{Turbo saxosus.}

Synonymy.

Turbo saxosus Wood Ind. Test. Supp. pl. ө. f. 45.

- Kiener Iconog. pl. 15. f. 2. pl. 16. f. 2.

1828. 1847. Reeve Conch. Icon. pl. 4. f. 14. Jan. 1848. Reeve in Proc. Zool. Soc. Lond. p. 49. Reeve Conch. Icon. pl. 13. f. 14. March 1848. Apr. 1848.

* Our unique specimen is imperfect. 
Mr. Reeve, in referring only to the MSS. of a private collection for the name of this species, appears to have overlooked the name and the tolerably correct figure in Wood's Index. Three extreme varieties are well represented by the figures in 'the Conch. Icon. Most of our specimens are intermediate between fig. $a$ and fig. $b$, having a second row of tubercles moderately developed above the middle of the last whorl, with a corres. ponding keel on the spire.

The operculum is very thick and deeply sculptured, A deep indentation corresponds to the apex, and deep narrow furrows occupy arcs of about $300^{\circ}$; of these furrows, the larger is midway between the apex and the margin, and three others are exterior to it. The surface is granular, and the sides of the furrows are rugose.

Station.-On rocks, not far from the low water mark of the neap tides.

Habitat.-Unknown; Wood. West Columbia; Cuming! Reeve.

Panama ; C. B. A.!

We collected 160 specimens on the reef at Panama. Half grown shells were numerous.

\section{Scalaria hexagona.}

Synonymy.

Sealaria hexagona Sowb. in Proc. Zool. Soc. Lond. p. 29 . Feb: 1844. Sowb. Thes. Conch. p. 98. No. 60. pl.

$$
\text { 33. f. } 67 .
$$

Station.-In the sands; Sowerby.

Habilat.-Acapulco; Col. Moffat! Sowerby. Acapulco; Jay. Panama ; C. B. A. 1

1 specimen was found. JULY, 1852. 


\section{Scalaria obtusa.}

Synonymy.

Scalaria oblusa Sowb. in Proc. Zool. Soc. Lond. p. 29.

Feb. 1844.

Sowb. Thes. Conch. p. 98. No. 03. pl. 33.

f. 54 .

1844.

Station.-Sandy mud at 6 fathoms; Cuming! Sowerby.

Habitat.-Punta St. Elena; Cuming! Sowerby.

Panama; C. B. A.I

1 specimen was found.

287. Scalaria. Sp. indet. a.

2 specimens, one of which was immature, were obtained at Panama.

288. Scalaria. Sp. indet. $b$.

1 specimen was obtained at Panama.

289. Scalaria. Sp. indet. c.

1 immature specimen was obtained at Panama.

Family-EULIMID Æ.

290. Culima iota. Nov. sp.

Shell subulate: smooth and shining: with a microscopic line a little below the middle of the whorls, above which line the shell is chalcedonic white and translucent, and below which it is transparent: apex subacute: spire much arcuated: whorls ten, moderately convex, with a distinct suture: aperture small, ovate, subeffuse:- labrum much advanced along the middle. It may be a STYLifer. Mean divergence about $20^{\circ}$; length .08 inch; breadth .03 inch; length of spire .06 inch.

Station.-Unknown.

Habitat.-Panama; C. B. A.!

We found 1 mature and 1 young specimen. 
291. Gulima recta. Nov. sp.

Shell long, ovate conic: chalcedonic white, with a more opaque and another less opaque spiral band at the upper part of the whorls; with two minute delicate brown spots on the la. brum, and above with several similar pairs of spots at the stages of growth: smooth and shining, with a few very faint trans. verse strim marking stages of growth: apex very acute : spire with the axis straight, with the outlines nearly rectilinear: whorls eleven, subplanulate, with the suture very indistinct; last whorl long, with the periphery very regularly rounded: aperture narrow and very acute above: labrum sharp, retreating anteriorly: columella stout, nearly straight.

Mean divergence about $21^{\circ}$; length .41 inch; breadth .1 inch; length of spire .285 inch.

Slation.-Unknown.

Habitat.-Taboga; C. B. A.1

5 specimens were collected.

\section{Eulima solitaria. . Nov, sp.}

Shell long, ovate conic: chalcedonic white, with a brownish tinge above the middle of the spire: smooth and shining : apex acute: spire with the axis nearly straight, with the outlines nearly rectilinear: whorls eleven, planulate, with the suture very indistinct: last whorl with the periphery very regularly rounded: aperture ovate, acute above: labrum sharp, much advanced along the middle into an elegantly curved edge: columella stout, slightly curved. This may be a StyLIFer.

Mean divergence about $23^{\circ}$; length .19 inch; breadth .055 inch ; length of spire .14 inch.

Station.-On Holothuriæ.

The small species of Holothuria, which is very common at Panama and at Taboga, did not furnish any specimens. $\mathbb{A}$ larger species, which is more rare, afforded one shell.

$$
\text { Habitat_-Taboga; C. B. A.! }
$$




\section{Family-TORN A TELLID EA.}

203. Pyramidella. Sp. indet.

A snow white shell, of which 1 specimen was found near Panama. It is probably a young shell, having only eight whorls.

\section{Pypamidella conica. Nor. sp.}

Shell long, regularly conic: white on the upper whorls, dark brown on the others, with a pale spiral line just above the suture: surface smooth and shining: apex very acute: spire with the outlines rectilinear: whorls fourteen, flat, with the suture in a narrow deep groove: last whorl sharply angulated at the periphery: aperture oblique: labrum thin: columella with three plaits, of which the one is lamelliform, and the other two are very small.

Mean divergence, about $23^{\circ}$; length . .52 inch; breadth .175 inch; length of spire .38 inch.

This species is remarkable for the exact conical form of the spire.

Station.-Unknown.

Habitat.-Panama; C. B. A.1

1 specimen was found.

\section{Family-NERITID必.}

NATICA.-We are deterred from the description of any indeterminate species in this genus, because several species, which belong to the same zoological province, are known to us only by brief descriptions. Even the species which was obtained most plentifully, we have not been able to determine: yet from its abundance, it must be well known. Monographs of Natica and Nerita are now greatly to be desired.

The success with which M. Recluz has devoted himself to this and to the allied genera is well known. By the thorough 
NATIOA.

exploration of a limited field, those who have but little leisure from other pursuits may add much 'to science.

\section{Natica Chemnitzii.}

Synonymy.

The synonymy of this species was overlooked until too late to be completed. With the partial data now before us, it appears to be Pfeiffer's $N$. Chemnitzii, which, and $N_{\text {. }}$ unifusciata. Lam., and $N$. lurida Phil., were included by .Koch (Zeitschr. fiir Malak. 1844. p. 154) in the Ohemnitzian species .N. maroccana, the N.marochiensis of Amelin, not of Lamarck. Proba: bly it is the N. maroccana of Menke in his catalogue of Mazatlan shells, in Zeitschr. für Malak. 1847, p. 179.

Station.-On soft mud near low water mark.

Habitat.-Mazatlan; Melchers! Menke. Guaymas; Lt.' Green! Mus. Essex Inst.: : also Gould MSS.

Panama; C. B..A.I

We collected 60 specimens at the bottom of the beach next east of Panama.

\section{Natica lurida:}

Synonymy.

Natica lurida (?) Phil. in Kast. Conch. Cab.

Slation.-Unknown.

Habitat.-Taboga; C. B. A.I

8 specimens were collected.

\section{Natica otis.}

Synonymy.

Natica otis Brod. and Sowb. in Zool. Journ. IV. 372.

- - Gray in Zool. Beech. Voy. pl. 84. f. 13. 1839 . Kuist. Conch. Cab. pl. 9. 1. 4. 
Station.-This beautiful speçies was found crawling on a sand beach, a little below half tide level. Like its congeners, it crawled half buried in the sand, leaving a furrow behind.

Habitat.-Mazatlan; Broderip and Sowerby : also Gray. Mazatlan; Jay.

Taboga ; C. B. A.!

11 specimens, mostly rather small, were taken on the north side of a sand beach, which, except at high water, joins Taboga to a small island on its northeast side. The specimens had corneous opercula, but unfortunately these were destroyed by the rats, which entered one of the boxes on their passage around Cape Horn.

\section{Natica Salangonensis ?}

Synonymy.

Natica Salangonensis (?) Recl. in Proc. Zool.Soc. Lond.p. 211. Dec. 1849.

Station.-Sandy mud; Cuming! Recluz. One of our specimens was taken alive in sandy mud between half tide and low water mark.

Habitat.-Salango; Cuming! Recluz.

Panama; C. B. A.I

10 specimens were collected.

\section{Natica Souleyetiana.}

Synonymy.

Natica Souleyetiana Recl. in Petit. Journ. Conch. I. 385.

pl. 14. f. 8. - - - - - Dec. 1850.

Station.-Unknown.

Habitat.-Pacific Ocean? Recl.

Panama; C. B. A.!

1 mature and 3 young specimens were found. 
NATIOA.

Panama Shells.

\section{Natica virginea ?}

Synonymy.

Natica virginea (?) Recl. in Petit. Journ. Conch. I. 388.

pl. 12. f. 6. - - - - - Dec. 1850.

The description and figure by M. Recluz, accurately represent a small specimen of our shells, except that the very minute crowded spiral strim are not mentioned. The outline is too regularly rounded to correspond well with the description of N. Panamaënsis Recl. Our largest specimen is 1.75 inch long, and 1.4 inch wide.

Station.-Unknown.

Habitat.-Realejos : Recluz. Panama; C. B. A.I

We collected 40 specimens, all of which were occupied by hermit crabs.

\section{Natica - Sp. indet. a.}

Station.-In wet sand, from half tide to low water mark. The tracks of this species were abundant on the beach, and led to the discovery of numerous living specimens.

Habitat.-Panama; C. B. A.!

We collected 200 specimens, mostly on the beach one mile west of the city.

\section{Natica —. Sp. indet. $b$.}

Two specimens of this species were sent to me by M. Petit as $N$. cora Orb. But the figures of that species in Orbigny's Voy. Amer. Merid. and in Kuist. Conch. Cab. represent a very different shell with the form (extraordinary in this genus) of a compressed cylinder; but our shells and M. Petit's have a well curved outline. It is a white and very solid but small species of the mammillate group. 
Station.-In wet sand.

Habitat.-Callao; Petit in sohed. Taboga; C. B. A. !

We found only 2 specimens.

\section{Natica - Sp. indet. $c$.}

Station.-Unknown.

Habitat.-Panama; C. B. A.!

We obtained only 1 imperfect specimen. It may possibly be a variety of $N$. Elence Recl. It scarcely differs from $N$. Haneti Recl. except in the absence of spiral striæ (which a better specimen might exhibit), and in the continuity of the transverse impressed lines across the last whorl.

NERITA.-In this genus we found an incredible profusiop of individuals, all of which belong to only two species.

\section{Nerita scabricosta.}

\section{Synonymy.}

Nerita scabricosta Lam. (non Delessert) An. sans Vert. VI.

Pt. 2. p. 194. No. $14 . \quad$ - $\quad$ - Apr. 1822.

- omata Sowb. Gen. pl. 4. f. 4.

1824.

Wood Ind. Test. Supp. pl. 8. f. 4.

1828.

- scabricosta Lam. An. sans Vert. VIII. 608. No. 14.

(Desh. Ed.) - $\quad$ - $\quad$ - $\quad 1838$.

- Deshayesii Recl. in Rev. Zool. (var.) Apr. 1841.

- ornata Reeve Conch. Syst. pl. 202. f. 4.

1842.

_ scabricosta Lam. An. sans Vert. III. Pt. 2. 486. No. 14.

(Desh. ed. tert.) - - - 1844.

- multiiugis Menke in Zeitsch. Mal. p. $170 . \quad$ Dec. 1847.

- Reeve Elem. Conch. pl. 16. f. 86. scabricosta Recl. in Petit. Journ. Conch. I. 287. 410.

pl. 11. f. 2. - - - - Sep. 1850.

By some mistake $N$. costata appears to have been figured in Deless. Rec. for this Lamarckian species. 
Most of our specimens are of $a$ uniform jet black color, with the exception of the eroded spire. Some are sparingly mottled with cream colored spots, and a few specimens have some small bright red spots on or near the labrum. Several are elegantly banded with narrow or broad spiral stripes of cream or orange colors. The young are more or less profusely mottled with white, grey, and greyish black.

Station.-On rocks between high water and three-quarter tide levels. They aro especially disposed to collect in the crevices of rocks. The young are commonly seen crawling above high water mark, where the rocks and stones are wet with spray.

Habitat.-Unknown; Lamarck: also Wood.

Real Llejos; Sowerby : also Recluz.

California; Philippi.

Mazatlan; Melchers I Menke.

I. of Timor; Recluz.

West Coast of South America; Petit.

Panama ; Jay.

Panama and Taboga; C. B. A.I

We collected 400 specimens on the reef.

Probably the statement of habitat (I. of Timor, ) by Recluz is erroneous. It was taken from the label of the Lamarckian specimen (long supposed to be unique) in the Massena Collection.

\section{Nerita - Sp. indet. a.}

This may be M. Bernhardi Recl., which is said to inhabit Panama, but we have not seen the description of that species.

Station.-On rocks and stones from half tide level to the low water mark of neap tides.

Habitat.-Panama; C. B. A.1

We collected 2,800 specimens. 


\section{Neritina Guayaquilensis.}

Synonymy.

Neritina Guayaquilensis Sowb, Thes, Conch, p. 520,

No, 44. pl. 114. f. 177. - - 1849.

This may, according to Recluz, be identical with $N$. inter: media Sowb. It is certainly identical with shells which have been distributed by Mr. Cuming and by Mr. Petit under the latter name. Mr. Sowerby's figures, however, seem to represent two species.

Station.-This shell was found a little above the highest tides, among sticks and leaves, in a muddy place overflowed by fresh water.

Habitat.-Real Llejos, Guayaquil ; Cuming! Sowerby. Panama; C. B. A.!

Two miles east of Panama we collected 90 specimens in various stages of growth.

\section{Neritina picta.}

\section{Synonymy.}

Neritina picta (non Hæning) Sowb. in Proc. Zool. Boc. Lond. p. 201. - - - + Dec. 1832. Desh. in Lam. An. sans Verț. VIII. 588, No. 40. - - - - - - 1838.

$\begin{array}{ll}- \text { Sowb. Conch. Ill. No. 35. pl. 86. f. 1. } & 1841 . \\ - \text { Desh. in Lam. An. sans Vert. III. Pt. } 2 . & \end{array}$ p. 479. No. 40. (Ed. tert.) - - - 1844. — Thes. Conch. p. 530. pl. 116. f. 267-9. 1849.

Station.-On a mud bank partially overflowed with fresh water ; Ouming! Sowerby ; "Dans les eaux douces ; Cuming!" Desbayes. On sticks and stones, in a grove of trees, a littlo above halftide level: also in dirty places on rocks at or a little below half tide level. According to our observations it is strictly marine.

Habitat.-Panama; Cuming! Sowerby. Panama; Recluz: also Jay. 
PEDIPES.

San Miguel; Lt. Green! Mus. Essex Inst.

Panama ; C. B. A.!

290 specimens were collected. The specimens which Lieut. Green collected are of extraordinary size.

\section{Family-AURICULID $\approx$.}

\section{Fedipes angulata. Nov. sp.}

Shell ovate globose: dark brownish red, white in the aperture: solid; with crowded wrinkled unequal raised spiral lines, which are much finer on the upper part of the whorls, and which on the middle of the whorls are larger, and are disposed with one or two smaller lines between the larger lines: apex subacute: spire with the outlines somewhat curvilinear; whorls a little more than four, vety angular, concave above the angle, imbricately appressed at the suture; last whorl large and ventricose, subangular below the middle : aperture subelliptical: labrum very sharp, sinuated by the angle on the whorls, a little within much thickened by a white callus, which is interrupted at the angle, and next below it, is developed into a long tooth : columella expanded with a broad flat surface, with two acute transverse plaits, of which the lower one is smaller: labium with a very large lamelliform spiral plait above the columella : umbilicus wanting.

Mean divergence about $90^{\circ}$; length .25 inch; breadth .19 inch; length of spire .1 inch.

Station:-Under stones at high water mark.

Habitat.-Panama; C. B. A. 1

We collected 90 specimens at the foot of the sea wall at Panama. This and the two species of Truncatella were found only in one place less than two yards in diameter.

Mr. Cuming obtained at Iquiqui a very small species of Pedipes, which has not been described. We believe that these two are the only known species in this zoological province. 
AURTCULA.-Eight species of this genus were found, and two of these occurred abundantly; but we have been able to determine only two of the less common species. The number of known species in the genus is very considerable, yet very few appear to be known which belong to the same zoological province in which Panama is situated. Two rather large species were collected by Mr. Cuming in West Columbia, and were described by M. Petit in the Proc. Zool. Soc. Lond. 1842.

\section{Auricula acuta.}

Synonymy.

Auricula acuta Orb. in Guerin Mag: Zool. p. 23.

1835.

- Orb. Voy. Amer. Merid. Moll. p. 326. pl. 42.

f. 4-6.

Marinula Recluziana Cuming in sched.

1852.

Station.-Near brackish water; M. Fontaine! Orbigny. Under stones near high water mark.

Habitat.-Near Guayaquil; M. Fontaine! Orbigny.

West Columbia; Cuming! in sched.

Panama: C. B. A.l

Only 1 mature and 2 young specimens were obtained.

\section{Auricula concinna. Nov, sp.}

Shell ellipsoidal : blackish brown, paler on the convexity of the last whorl, with a yellowish white spiral band on the last whorl issuing from beneath the suture; with the plaits and callus in the aperture white: smooth and shining: apex acute: spire with the outlines very curvilinear: whorls five, convex, imbricately appressed, with the suture moderately impressed; last whorl long: aperture narrow and very acute above, much contracted by the plaits : labrum sharp, in the lower part much thickened within by a broad thick deposit: plaits three, of which the lower one is very oblique, and the upper one is very large, 
concave on the lower side, and on the upper side extended to the summit of the aperture with a transyersely ridged surface.

Mean divergence about $80^{\circ} ;$ length 32 inch; breadth 2 inch; length of spire .099 inch.

Station.-Our specimens were found mostly on the short suckers, which were growing up thickly beneath the mangroves, near high water mark.

Habitat.-Panama; C. B. A.!

We collected 74 specimens two and one-half miles east of Panama.

\section{Auricula infrequens. Nor.sp.}

Shell ellipsoidal : brown, with a pale ill-defined spiral band a little below the suture: ,with fine striæ of growth: apex acute: spire with the outlines moderately curvilinear: whorls six, obtusaly shouldered, with a deep suture; last whorl compressed: aperture subelliptical, rather wide:" labrum very thin : with two plates, of which one is at the anterior part of the aperture and is oblique, and the other is transverse and is at the middle.

Mean divergence about $80^{\circ}$; length .23 inch; breadth .15 inch ; length of spire 1 inch.

S Station- - Under stonęs, near high water mark.

Habitat.-Panama; C. B. A.1

We collected 6 specimens, in company, with Pedipes angulata, at the base of the sea wall of Panama.

\section{Auricula Panamensis. Nọv. sp.}

Shell long ovate: blackish red throughout except that the plaits are white: smooth and shining, with a few microscopic spiral strix near the apex : apex acute: spire with the outlines very curpilinear oyer the middle whorls, and nearly rectilinear on the lower whorls: whorls eight, convex, imbricately appressed; 
upper part of the lower whorls compressed; last whorl subangular next below the compressed part : aperture rather long, very acute above: labrum moderately thickened but not reflected : with three plaits on the left side, of which the middle one is larger and the lower one is the least; sometimes with a small toothlike plait on the right side.

The general form varies, as will be seen in the following dimensions of two specimens, the first number expressing the mean divergence, the second the length, the third the breadth, and the fourth the length of the spire:-

$50^{\circ} ; .44$ inch $; .17$ inch; .23 inch.
$65^{\circ} ; .37$ “ 2.2 " $; .13$ "

Station.-Under stones, at high water mark; or crawling over wet stones.

Habitat.-Panama and 'Taboga ; C. B. A.!

650 specimens were collected near the sea wall of Panama, where the species was most abundant.

\section{Auricula stagnalis.}

Synonymy.

Auricula stagnalis Orb. in Guerin Mag. Zool. Synop. p. $23 .^{*}$ - - July 1835. Reeve Conch. Syst. pl. 187. f. 9. (loo narrow.) 1842. Orb. Voy. Am. Mer. p. 325. pl. 42. f. 7, 8. 1846. papillifera Küst. p. 25. stagnalis Küst. p. 70. $\}$ pl. 3. f. 9, 10, 10*.

Slation.-In a marsh, and even in stagnant fresh water; $M$. Fontaine! Orbigny.

Our specimens were found under a heap of stones just above high water mark.

* The vol. of the Mag. is not paged continuously, nor are the new species of Mollusca, which are described by D'Orbigny, enumerated in the Table Methodique. Küster appears to be in error when he ascribes the authorship of this article to M. Petit. 
Habitat.-Guayaquil; M. Fontaine! Orbigny. West Columbia; Cuming ! Küster. I. of Tumaca; Cuming $!$ in sched. Panama; C. B. A. 1

At the base of the sea wall of the city we collected 36 specimens in various stages of growth. They are rather more robust than the species is represented in the figures above cited.

\section{Auricula Tabogensis. Nov. sp.}

Shell obovate: very dark brownish red, more or less rufous on the columella, usually white on the plaits and callus within: smooth and shining, with some fine spiral strim on the upper whorls: apex acute: spire with the outlines very curvilinear: whorls ten, imbricately appressed, with a distinct suture: last whorl large : aperture long and narrow, in the right side mostly covered by a transversely ridged callus : with three plaits on the left side, of which the upper one is a little larger, and the two lower are separated by a sinus.

Mean divergence about $100^{\circ}$; length .59 inch; breadth .36 inch; length of spire .15 inch.

Two specimens of $A$. fusca Phil, which we have received from M. Petit, are more angular in the upper part of the whorls, and have the callus within the labrum more finely and closely ridged. A. fusca, as figured by Kiister, more robust and less pyriform than our shell. According to M. Petit's label, $A$. fusca occurs at the Marquesas, and Kuister mentions the Sandwich Islands as its habitat. In outline our shell resembles $A$. pyriformis Petit (West Columbia, Cuming !), but within the aperture there is no resemblance.

Station.-On and under stones and rocks at high water mark.

Habitat.-Taboga and Panama; C. B. A.I

800 specimens were collected. 


\section{Aunicula trilineata. Nov. sp.}

Shell obovate: dark brownish red,' with three revolving distant white lines on the last whorl, of which the anterior line is not so well defined: rufous on the columella: with irregular strioo of growth: apex obtuse? spire very small, with the outlines curvilinear: whorls _, $\ldots$ very narrow, imbricately appressed, with the suture distinct: last whorl very large, convolate: aperture very long, narrow : labrum not sharp, with a deposil over the whole visible interior, which is transversely plaited: at the end of the columella with a twisted plait, separated , by a sinus from , a large transyense plait, abave w wich are four small approximate transvęrse plaits.

Mean , divergence ;about $135^{\circ}$; length , 71, inch; inreadth , 43 inch ; length of spire .05 inch.

Station.-Unknown.

Habitat.m-Panama; C. B. A.!

Oaly 1 specimep was found.

\section{Auricula $\longrightarrow$ - Sp. indet.}

Slation.-Under stones at high water mark.

Habitat_Panama ; C. B. A.!

We abtained 2 specimens, which, although immature, appear distinct from the other species of Auricula.

\section{Family-CYCLOSTOMIDÆ.}

IRUNCA PELLA.-We include this genus, as well as sedipes and Auricula, in this paper, because they are maritime in their habits. Their geographical distribution, corresponding with that of the marine genera, is entirely different from that of the terrestrial molluses.

* In our unique specimen the suture of the upper whopls is abliterated by erosion. Probably the number of whorls is ojy or sepven. 
317. Truncatella Bairdiana, Wova sp. :

Shell cylindric: of a rich amber color: with rather small crowded ribs, which are obsolete behind the labrum, less pro. minent on the convexity of the whorls, well developed anteriorly, in number about twenty-four on the penult whorl: apex acute, truncate with the loss of four whorls: spire with the outlines slightly curvilinear; whorls nearly four after truncation, convex, with a well impressed suture: aperture ovate, slightly effuse above: labrum advanced along the middle, reflected, double: labium with a thick deposit, continuous with the labrum.

Mean divergence about $22^{\circ}$, being considerably less in the lower whorls and more above; length after truncation, .21 inch; breadth .075 inch; length of spire .15 inch.

This species must resemble $T$. scalariformis Reeve from the island of Annaa; but that shell is figured with five whorls after truncation, in color it is described as "luteola," and the labrum is said to be sharp and simple.

Station.-Under a heap of stones at the high.water mark of spring tides.

Habilat.-Panama; C. B. A.!

400 specimens were collected at the bottom of the $e_{t}$ sea wall of Panama.

One specimen has come to maturity without the loss, of the apex, which, however, is .white and cretaceous from partial decay.

We dedicate this species to Professor S. F. Baird, whose name is so well known to Herpetologists.

\section{Truncatella (??) dubiosa. Nor. sp.}

Shell ovate conic: translucent, deep yellowish brown : thin, smooth, and shining: apex subacute: spire with the outlines moderately curvilinear: whorls six, convex, with a well 
impressed suture; last whorl rather short and subangular, but ventricose: aperture broadly ovate: labrum thin: labium a little reflected below, above interrupted by the penult whorl.

Mean divergence about $45^{\circ}$; length .083 inch; breadth .055 inch; length of spire .045 inch.

Operculum corneous.

Station.-With Truncatella Bairdiana.

Habitat.-Panama ; C. B. A.1

550 specimens were collected.

This species cannot properly be referred to Truncatella. The apex is not truncated; the operculum is horny ; and the general form and texture indicate a different genus. In form it approximates to T. fusca, T. littorea, \&c., which are not Truncatellæ, but which probably belong to Bembicium. From the habits of our species, it may be inferred to be an air-breathing mollusc, while the characters of the shell are very different from those of Bembicium. The shell appears too deficient in characters suitable for generic distinction, and we refrain from proposing a new genus until the soft parts shall be known.

\section{Family-BULLID $\nRightarrow$.}

\section{Bulla (Tornatina) infrequens. Nov. sp.}

Shell cylindric, not compressed about the middle: white: smooth: apex papillary, very minute and prominent: spire moderately elevated, convex: whorls four and one-half, acutely shouldered, with a deeply channeled suture: aperture long and narrow, anteriorly rounded: labrum very thin, much advanced along the middle: columella terminating in a very robust spiral plait.

Mean divergence about $130^{\circ}$; length .28 inch; breadth .11 inch; length of spire .03 inch.

Station.-Unknown. 
Habitat.-Panama ; C. B. A.!

2 specimens were found.

\section{Bulla (Cylichna) Iuticola. Nov, sp.}

Shell subcylindric, wider anteriorly: pale horn color, subtransparent: with the strim of growth very minute: apex in a deep narrow umbilicus, which is partly covered by the upper part of the labrum: last whorl compressed around the middle : aperture rising higher than the umbilicus, linear above, suborbicular below: labrum very thin, much advanced along the middle: columella thickened with a callus: anterior umbilical region indented, partly covered with a deposit.

Length .2 inch; breadth .095 inch.

Station.-This species was found crawling on liquid mud, near low water mark, at the bottom of a steep sand beach.

Habitat.-Panama; C. B. A.1

28 specimens were collected half a mile east of Panama.

\section{Bulla punetulata.}

Synonymy.

Bulla punctata Ad. in Sowb. Thes. Conch. p. 577. No. 53.

pl. 123. f. 77. - - - - 1849. punctulata Ad. in Sowb. Thes. Conch. Index. 1849.

Station.-Sandy mud, 10 fathoms; Cuming! A. Adams.

Habitat.-Panama; Cuming! A. Adams.

Acapulco; E. Jewett ! Gould MSS.

Taboga; C. B. A.I

25 specimens were found in various states of preservation.

\section{I Uulla —. Sp. indet.}

Another species is represented by 1 imperfect specimen. 
Family-VERMETID $\approx$.

\section{Vermetus glomeratus ?}

Synonymy.

I Serpula glomerata Var. b. (alt. excl.) Lam. An. sans

Vert. V. 363. No. 6. - - July 1818.

Var. b. (alt. excl.) Lam. An. sans

Vert. V. 619. No. 6. (Desh. ed, $)^{\prime}, \cdot 1838$.

Vermetus glomeratus Rousseau in Chenu, Mll. Conch. pl. 2. f. 2. 1843. centiquadrus? Val. Voy. Venus, Moll. pl. 11. f. 1.

1846.

Station.-Attached by a small part of the spiral portion of the shells to rocks and stones near the low water mark of neap tides.

Habitat.-Mazatlan; Melcherș! Mẹke.

Panama; C. B. A.l

We collected 25 specimens on the reef.

\section{Vermetus Panamemsis...........}

Synonymy.

Vermetus Panamensis Rousseau in Chenu. Ill. Conch. pl. 5. f. 1. 1843.

Station.-In the same situations as $V$. glomeratus, attached on one side of all the whorls.

Habitat.-Panama; C. B. A.1

10 specimens were collected.

Of these two species of Vermetus, a much larger number of specimens might have been collected, with some additional labor in carefully detaching them from the rocks.

Family-HALIOTID无.

325. Stomatella inflata. Nov. sp.

Shell very obliquely elliptical; white, thick and opaque anteriorly, above thinner and translucent: with very fine irre- 
gular striæ of growth; without spiral striæ: apex minute, obtuse, prominent: whorls two, very convex, with a well impressed suture; last whorl very oblique, much inflated and very convex : aperture contracted, yet exhibiting the spiral columella to the apex; columellar side of the aperture abruptly arcuated.

Length obliquely .45 inch; breadth obliquely .31 inch.

Station.-Unknown.

Habitat._Panama ; C. B. A. 1

1 specimen was found.

Family-CALYPTR 正ID E.

\section{Hipponyx —. Sp. indet.}

We found of this species only 2 small specimens, which probably are immature. The spire has more than two whorls. They may be the young of Hipponyos subrufa Sowb. Lam.? The Lamarckian Pileopsis subrufa is probably the Caribbean species, of which Mr. Sowerby's species is the Pacific analogue.

\section{Ilipponyx barbata ?}

\section{Synonymy.}

Hipponyx barbata? Sowb. in Proc. Zool. Soc. Lond. p. 5. Jan. 1835. ? Sowb. Thes. Conch. p. 369. No. 1. pl. 73. f.

$$
26,27 .
$$

Our shells correspond very nearly to the description and figures by Sowerby. Yet they may be distinct. It will be seen that they belong to a distinct zoological province. Our specimens also resemble Pileopsis pilosus Desh. in Guer. May, 1832, pl. 19.

Station.-On stones and shells near low water mark.

Habitat.-Ad Insulas Maris Pacifici. Found on coral reefs around Toobouai, one of the Society Islands; Cuming! Sowerby.

JULY, 1852. 
Panama; $\mathbf{C}, \mathbf{B}, \mathbf{A}$, !

12 specimens were collected.

\section{Hipponyx Panamensis.}

\section{Synanymy,}

Hipponyz mitrula Sowb. (non Lam.) in Proc. Zool. Soc. Lond.

p. 5. = - = I = Jan. 1835. Sowb. (non Lam.) Thes. in Conch. p. 369. No.

2. pl. 73. f. 18-20.

We propose this name for a shell, which Mr. Sowerby seems to have confounded with $H$. mitrula Lam. The Lamarckian shell is the Caribbean species, which has a curved apex that is sometimes much elongated, "apice adunco " Lam. The Panama shell is obliquely conic, with the apex moderately prominent. The concentric laming are more numerous and the radiating strix on them are more deeply impressed than in the Caribbean shell. This species is thick and solid.

Length .67 inch; breadth .7 inch; height . 37 inch.

A dead specimen of Cardita affinis has on one valve 4 rather small individuals. The attached valves are rather thin, and have been more or less perforated, from within the Cardita, by some boring animal. Around the perforations there is a thicker deposit, which fills up some of them.

Station.-On stones in 17 fathoms water, among coarse sand; Cuming! Sowerby. Our specimens were found on stones and shells near low water mark.

Habitat -=Lobos I.; Cuming ! Sowerby.

Panama; C. B. A. !

14 specimens were collected.

\section{\$20. Hipeonyx radiata.}

Synonymy.

fripponyx radiata Sowb. in Proc. Zopl. Sac. Lond, p. 5.. Jan. 1835. Sowb. Thes. Conel. p. 370. No. 4. pl. 79. f. 24, 25. 1846. 
Station.-Attaohed to rocks; Cuming | Sowerby. Our specimens were found attached to stones near low water mark.

Habitat_-Panama and the Gallapago Is.; Cuming I Sowerby. Panama; C. B. A.!

16 specimens were collected.

\section{Calyptraea aberrans. Nov. sp.}

Shell irregularly, somewhat concave externally : papyraceous, pearly, with fine irregular stris of growth : apex very minute, subterminal : the cup in our unique specimen is probably imperfeat: what remains consigts of a very thin, deeply concave, narrow lamina, transversely attaohed under the apex of the shell. In texture this ahell much resembles. valve of an Anomia.

Length .7 inch; breadth .59 inch.

Station.-Unknown.

Habitat._Panama; C. B. A.!

Only 1 specimen was found.

331. Calyptraea (Syphopatella) aspersa. Nov. sp.

Shell conic: thin: dingy or brownish white, irregularly sprinkled with many reddish brown spots: with very short and irregular minute wrinkles: apex acute, central: lamina with the fold appressed only at the inner margin, broadly expanded, making about two thirds of a revolution: margin very thin and acute.

Biameter .55 inch; height .21 inch.

Strtion.-Under stones at low water mark.

Habitat._Panama; C. B. A.I

3 specimens were found. 


\section{Calyptraea cepacea.}

Synonymy.

Calyptrcea cepacea Brod. in Proc. Zool. Soc. Lond. p. 35. May 1834. Brod. in Trans. Zool. Soc. Lond. I. 197.

pl. 27. f. 4. - - - - - 1835.

- Müll. Synop. Nov. Test. Viv. p. 142. May 1836.

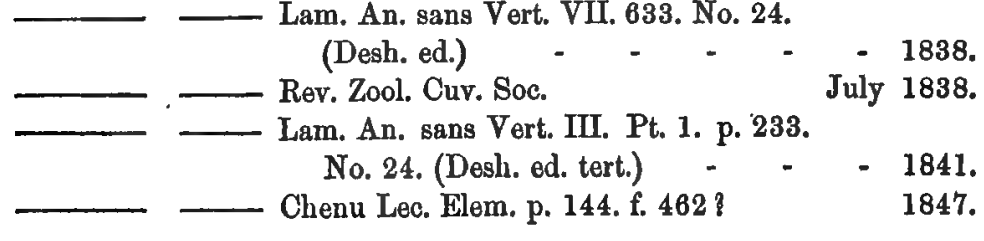

Station-Adhering to dead shells, in sandy mud, at a depth of 11 fathoms; Cuming! Broderip.

Our specimens were found adhering to dead shells, at low water mark.

Habitat.-I. of Muerte; Cuming! Broderip: also Deshayes : also Rev. Zool. : also Müller.

Mazatlan; Melchers! Menke.

Panama; C. B. A. 1

4 small specimens were found.

333. Calyptraea comica.

Synonymy.

Calyptrcea (Syphopatella) conica Brod. in Proc. Zool. Soc. Lond. p. $38 . \quad$ - May 1834. - Brod. in Trans. Zool. Soc. Lond. I. 202. pl. 27. f. 7. 1835. — Mull. Synop. Nov. Test.

Viv. p. 147. - - May 1836.

- Lam. An. sans Vert. VII. 630.

No. 17. (Desh. ed.) - 1838.

— Lam. An. sans Vert. MII. Pt. 1.

p. 232.No. 17. (Desh. ed. tert.) 1841.

Station.-Attached to shells in deep water; Cuming I Broderip. 
CALYPTRARA.

Habitat.-Xipixapi and Salango; Cumingl Broderip: also Müller.

Panama ; C. B. A.I

12 specimens were obtained.

\section{Calyptraea dentata.}

\section{Synonymy.}

Calyptrcea rugosa Reeve (non Desh.) Conch. Syst. pl. 144. f. 1. 1842. dentata Menke Zeitschr. Malak. p. 185.

Dec. 1847.

Station.-Unknown.

Habitat.-Mazatlan; Melchers! Menke.

Panama; C. B. A. 1

8 specimens were collected.

\section{Calyptraea hispida.}

Synonymy.

Calyptrcea (Calypeopsis) hispida Brod. in Proc. Zool. Soc.

Lond. p. 37. - - May 1834. Brod. in Trans. Zool. Soc. Lond.

I. 200. pl. 27. f. $10 . \quad-\quad 1835$.

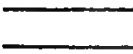

Müll. Nov. Test. Viv. p. 144. May 1836.

- Lam. An. sans Vert. VII. 638.

No. 36. (Desh. ed.) - 1838.

- Rev. Zool. Cuv. Soc. July 1838.

Lam. An. sans Vert. Pt. 1. p. 233.

No. 36. (Desh. ed. tert.) 1841.

Chenu Lec. Elem. p. 144. f. 464. 1847.

Our specimens vary much in form and in coloring. Some are almost flat, but the cup is as deep in such as in the more conical shells: such specimens grow on a concave surface. One shell, instead of having a subcircular outline, has the outline of a very eccentric ellipse. The color of some is nearly white; of others, a deep brown; many are spotted and striped in the manner described by Mr. Broderip. 
Station.-On dead shells, in sandy mud, at a depth of 12 fathoms; Cuming! Broderip.

Our specimens were found under stones at low water mark.

Habitat.-I. of Muerte; Cuming! Broderip : also Rev. Zool.; also Miuller.

I. of Muerte; Deshayes : also Jay.

Panama and Taboga; C. B. A.!

20 specimens were colleoted.

\section{Calyptraea imbricata.}

Synonymy.

Calyptraa (Calypeopsis) imbricata Brod. in Proc. Zool. Boc.

Lond. p. 36. - - May 1884. Brod. in Trans. Zool. Soc. Lond.

I. 193. pl. 27. f. 7. - - 1835. Müll. Synop. Nov. Test. Viv.

p. 143. - - - May 1838. Lam. An. sans Vert. VII. 636.

No. 33. (Desh. ed.) - - 1838. Rev. Zool. Cuv. Soc. July 1838.

$\bar{\square}$ Hanley Conch. Book Spec.

p. 13. - - - - 1842. Orb. Voy. Amer. Merid. Moll.

p. $460 . \quad-\quad-\quad-1843$.

Station.-On stones in sandy mud at a depth of from 6 to 10 fathoms; Cuming! Broderip.

Habitat.-Panama; Cuming ! Broderip : also Rev. Zool. : also Müller.

Oentral Amerioa; Deshayes.

Payta; Orbigny.

Panama; O. B. A. 1

2 specimens were found.

As M. Deshayes mentions another habitat, it is to be regretted that the authority is not stated. 
OALTPTRAA.

\title{
397. Calyptraea maculata.
}

\author{
Synonymy.
}

Calyptraca (Calypeopsis) maculata Brod. (non Quoy) in Proc.

Zool. Soc. Lond. p. 37. May 1834.

Brod. in Trans. Zool. Soc.
Lond. I. 200. pl. 27. f. 11.
Mull. Synop. Nov. Test.

Brod. in Trans. Zool. Soc.
Lond. I. 200. pl. 27. f. 11. 1835 .
Mull. Synop. Nov. Test.

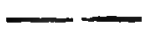

Viv. p. 145. - - May 1836:

Lam. An. sans Vert. VII. 638.

No. 37. Desh. ed. - 1838.

- Rev. Zool. Ouv. Soc. July 1838.

Station.-In sandy mud on dead shells at a depth of 11 fathoms; Cuming! Broderip.

Habitat.-I. of Muerte; Ouming! Broderip : also Rev. Zool.

I. of Muerte; Deshayes.

Panama; C. B. A. 1

2 specimens were found.

338. Calyptraea planulata. Nor. sp.

Shell flat, suborbicular: thin : pure white: with very minute radiating stria, which are obsolete around the apex: apex subcentral, acute, slightly elevated above the plane of the shell: cup with the sides free and the corners acute, thin, curved through about $220^{\circ}$ : margin very thin. It belongs to Calyp. troea as restricted by Broderip.

Length .32 inch; breadth .35 inch.

Station.-Adhering to an oyster, a little below half tide level.

Habitat.-Panama; C. B. A.!

Only 1 specimen was found.

\section{Calyptraea radiata.}

Synonymy.

Calyptraza (Calypeopsis) radiata Brod. in Proc. Zool. Soo.

Lond. p. 36. - - May 1834. 
Calyptraea radiata Brod. in Trans. Zool. Soc. Lond. I. p. 198. pl. 27. f. 6. - - - - 1835. Müll. Synop. Nov. Test. Viv. p. 143. May 1836. Lam. An. sans Vert. VII. 635. No. 31. (Desh. ed.) - - - - 1838. Rev. Zool. Cuv. Soc. July 1838. Lam. An. sans Vert. III. Pt. 1. p. 234. No. 31. (Desh. ed. tert.) - - - 1841. Chenu Lec. Elem. p. 144. f. 460, 461. - 1847.

Station.-Sandy mud on dead shells at a depth of 7 to 14 fathoms; Cuming! Broderip.

Habitat.-Bay of Caraccas; Cuming! Broderip: also Rev. Zool. : also Müller.

Seas of South America; Deshayes.

Bay of Caraccas; Jay.

Panama ; C. B. A. 1

10 specimens were collected.

340. Calyptraea (Syphopatella) regularis. Nov. sp.

Shell with a circular margin, regularly conic: moderately thickened: snow white, tinged with brown about the apex: with very fine lightly impressed strim of growth, somewhat shining: apex subacute, subcentral: lamina folded so as to form a tube about one-third of its own width, produced to the margin so as to make one complete revolution: margin acute.

Diameter 1.27 inch; height .55 inch.

Station.-Unknown.

Elabitat.-Mazatlan; Lt. Green! Mus. Essex Inst. : also Gould MSS.

Panama; C. B. A. 1

3 specimens were obtained. 


\section{Calyptraea' umbrella.}

Synonymy.

Calyptrcea umbrella Desh. in Encyc. Meth. Vers، II. 1 73.

(1st ser. pag.) - - - - 1830.

- rudis Brod. in Proc. Zool. Soc! Lond. p. 35. May 1834.

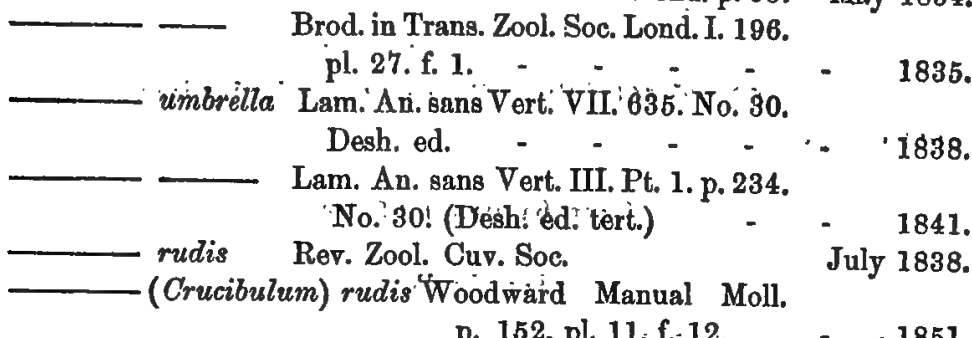
p. 152. pl. 11: f.-12. $\quad-\quad 1851$.

Station.-Under stones; Cuming ! Broderip.

'Habitat.-Panama and Real Llejos: Cuming I Broderip: also Rev. Zool.

Seas of Central America; Deshayes.

West Anderica; Woodward.

Guajáquil ; Jäy.

Panaima; C. B. A. I

Only 1 specimen was found.

\section{Calyptraea unguis ? ?}

We found one immature specimen which may belong to this species.

\section{Crepidula cerithicola. Nov. sp.}

Shell ovate, convex: posteriorly whitish, sometimes with a broad ray of dark brownish red on each side of the umbo; anteriorly subtransparent, pale brownish red, with narrow dark rays of the same color; sometimes all the rays are confluent, and more rarely the entire shell is of a dark brownish red; with the septum white: smooth: apex acute, terminal and ninarginal, a little dextrorsal : septum slightly angulated along 
the middle, with a small sinus at the left, a broad one at the middle of the edge, and none at the right side.

Length .23 inch: breadth .14 inoh; convexity .07 inch.

Station.-On Cerithium irroratum, q. v.

Habitat.-Taboga; C. B. A.!

This species was not observed until after the shells arrived here. When cleaning a quantity of $C$. irroratum, 45 specimens were obtained.

\section{Crepidula echinus.}

Synonymy.

Calyptraea (Crepipatella) echinus Brod. in Proc. Zool. Soc.

Lond. p. 39. - - May 1834. Brod. in Trans. Zool. Soc.

Lond. I. 203. pl. 27. f. 1. 1835. Müll. Synop. Nov. Test. Viv. p. 148. - - May 1836.

Crepidula Lam. An. sans Vert. VII. 650. No. 23. (Desh. ed.) 1838. - Lam. An. sans Vert. III. Pt. 1. p. 239, No. 23. (Desh. ed. tert.) - - 1841.

Station.-Under stones at low water.

Habitat.-Lobos I.; Cuming ! Broderip : also Müller. Peru; Deshayes : also Jay.

Panama; C. B. A!

18 speoimens were obtained.

\section{Crepidula excavata.}

\section{Synonymy.}

Calyptraea (Crepidula) excavata Brod. in Proc. Zool. Soo. Lond. p. 40. - - May 1834. Brod. in Trans. Zool. Soc. Lond. I. 205. pl. 29. f. 7. 1835. 
Calyptraea (Crepidula) excavata Müll. Synop. Nov. Test.

Crepidula Viv. p. 150. - - May 1836. Lam. An. sans Vert. VII. 649. No. 10. (Desh. ed.) 1838. Lam. An. sans. Vert. III. Pt. 1.

Station.-Unknown. p. 239. No. 19. (Desh. ed. tert.) 1841.

Habilat.-Real Llejos; Cuming! Broderip. Chili ; Deshayes. Panama ; C. B. A.!

1 specimen was obtained.

In the absence of testimony, the habitat mentioned by Deshayes must be considered as doubtful.

\section{Crepidula hepatica?}

\section{Synonymy.}

Crepidula hepatica Desh. Encyc. Meth. Vers. II. 26. (2d ser. pag.) 1830. - Lam. An. sans Vert. VII. 646. No. 12. (Desh. ed.) - $\quad$ - $\quad$ - $\quad$ - 1838. Lam. An. sans Vert. III. Pt. 1. p. 238. No. 12. (Desh. ed. tert.) - $\quad$ - $\quad$ - 1841. Menke in Zeitsch. Mal. p. 184. - - Dec. 1847.

Our specimens have an epidermis, which is more or less lamellar or pilose. Deshayes describes the shell as,having a smooth exterior surface, but Menke says "confertim distinctè porcata." Our shells exhibit a variation in the character of the surface, which reconciles this apparent discrepancy. A variety is very convex.

Station.-Adhering to Strombus Peruvianus, q. v.; also to Purpura tecta, q. v.

Another specimen is on a Conus gladiator, and is very convex; probably in consequence of the very convex surface to which it adheres. Some specimens are longitudiually recurved but laterally very convex; conforming to the surface on which they grew. 
Habitat.-Unknown; Deshajes. Mazatlan; Melchers! Menke.

: Mazatlan; E. Jewett! Gould MSS.

Taboga and Panama; C. B. A.!

\section{. 28 specimens were collected.}

According to Dr. Krauss, C. hepatica occurs iat the Cape of Good Hope. We have several specimens, collected at the Cape by Dr. $\mathrm{K}$., of his convex variety, which differs from our shells in having the septum very deeply placed, and the beak very prominent. The depressed variety figured by Dr. K. may more nearly resemble the Pacific shell, but we have no specimens for comparison. Probably, however, the Cape shells belong to a distinct species: but as the habitat of the original type was not known, and as the original description is applicable to both, we must leave this question undecided.

\section{Crepidula incurva.}

\section{'Synonymy.}

Calyptraca (Crepidula) incurva Brod.. in Proc..Zool. - Soc. . Lond. p. 40. - - May 1834. Brod. in Trans. Zool. Soc. Lond. pl. 29. f. 6. - 1835. Müll. Synop. Nov. Test. Viv. p. $150 . \quad--\quad$ Maj- 1836. Orb. Voy. Amer. Merid. Molls p. 468. - - 1843.

'Station.-On dead shells dredged from sandy mud; at a depth ranging from 6 to 10 fathoms; Cuming! Broderip.

Our. specimens were found adhering to..living shells at and near low water mark. Its favorite station was on the. shell which we have mentioned as. Thochus sp. indet. $b$, almost every one of which supported one or more of this Crepidula. Turbo saxcosus. was next in the frequency with which : it : furnished specimens. The species was found also on Columbella rugosa, C. varia, Buccinum ringens, Purpura tecta, $P$. undulata, Trochus 
CREPIDULA.

Panama Shells.

Buschii, T. reticulatus, \&c. Frequently also they are attached one to another.

Habitat.-St. Elena, and Xipixapi ; Cuming | Broderip.

St. Elena; Jay.

Payta; Fontaine! Orbigny.

Panama; C. B. A. 1

120 specimens were collected. 2 specimens in the Mus. Amh. were sent by a German conchologist, as having come from Peru.

\section{Crepidula Lessonii.}

Sÿnonymy.

Calyptraa (Crepidula) Lessonii Brod. in Proc. Zool. Soc.

Lond. p. 39. - - May 1834.

Brod. in Trans. Zool. Soc.

Lond. I. 204. pl. 29. f. $5 . \quad 1835$. Mull. Synop. Nov. Test.

Viv. p. 149. - May 1836.

Crepidula Lam. An. sans Vert. VII. 649. No. 20. (Desh, ed.) 1838.

— Lam. An. sans Vert. III.Pt. 1.

p. 239. No. 20. Desh. ed. tert. 1841

This species is remarkable for the very broad far projecting laminæ, which occupy the surface. Most of our specimens are nearly or wholly destitute of the brown longitudinal lines.

Station.-Under stones at low water; Cuming! Broderip.

Our specimens were found in the same situation.

Habitat.-I. of Muerte; Cuming I Broderip: also Müller.

I. of Muerte; Deshayes : also Jay.

Panama; C. B. A. 1

. 80 specimens were collected on the reef.

340. Crepidula squama.

Synonymy.

Calyptraea (Crepidula) squama Brod. in Proc. Zool. Soc. Lond.

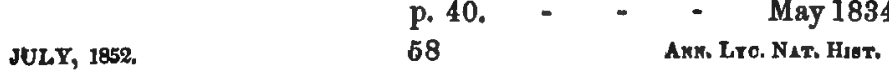


Calyptracea (Crepidula) squama Brod, in Trans, Zool. Sgẹ. Lond,

I. 205. pl. 29. f. $10 . \quad-\quad 1835$. Müll. Synop. Nov. Test. Viv. p.

151. - - - - May 1836.

Crepidula Lam. An, sans Vert. VII. 648. No, 1B, (Desh, ed, ) - 1898. Lam. An, sans Vert, III. Pt. 1. p. 239, No. 16. (Desh. ed. tert.) 1841.

The specimens vary much in color: the normal arrangement is with dark reddish brown rays on a whitish ground; in some shells the rays are fow and faint; in others they are crowded or even confluent. The surface is incurved or excurved according to the figure of the spot on which they grow.

Station.-Under stones and in dead shells near low water mark.

Habitat.-Panama; Cuming ! Broderip : also Müller.

Panama; Deshayes : also Jay.

Panamạ; O. B. A.!

i.

\section{Crepidula unguiformis.}

\section{Synonymy.}

Gualt, Tept. pl. 69, f. 11,

1742 ,

Palella crepidula Linn. Syst. Nat. p. 1257. No.752.(Ed. 12.) 1767. Gmel. in Linn. Syst. Nat. p. 3695, No. 17. 1788. Turt, Lipn, Syst. Nat. IV, 554, 1806. Broc. Foss. Subapp. II. 253.

Crepidula unguiformis Lam. An. sans Vert, VI. Pt. 2. p. 25. No, 4. 1818. - Iialica Defr. Dict. des Bc. Nat. XI. 397, plana

Say Journ. Acad, Nat, Sc: Phil, (Old Ser.) II. 226. - - - - July 1821. Dict. Classique d'Hist. Nat. V. 54. April 1824.

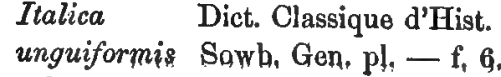
1824. Desh. Encyc. Meth. Vers. II. 26. No. 6. (2nd ser. pag.) - $\quad$ - $\quad 1830$. plana Say Amer. Conch. pl. 44. 
Crepidula unguiformis Brod. in Trans. Zool. Soc. Lond. I. pl. 29.

f. 4

- Müll. Syn. Nov. Test. Viv. p. 151. May 1838. Lam. An. sans Vert. VII. 643. No. 4.

(Desh. èd.) - - $\quad 1838$. Pot. et Mich. Gal. Moll. Mus, Douai. I. 514. 1838. plana Gould Invert. Mass. p. 158. f. 16. 1840. unguiformis Lam. An. sans Vert. IIL. Pt. 1. p. 236.

(Desh. ed. tert.) - - 1841 .

\begin{tabular}{llr} 
& Reeve Conch. Syst. pl. 143. f. 6. & 1842. \\
\hline dilatata & No.4. Orb.Voy.Amer. Merid. Moll. p. 467. 1843.
\end{tabular} plana Dekay Zool. of N. Y. Moll. p. 158. pl. 7. f. $153, a . b$.

1843.

This shell is well caloulated to confound the popular notion of species. We have now before us many perfect apecimens from Sicily, from Massachusetts, from Jamaica, and from Panama, all of which, with the exception of the Mediterranean shells, we collected in person. They present many modifications of form dependent on progress of growth, and the positions which they occupy in dead shells. But we have in vain attempted to discover any eharacteristies of locality. The only approach to a local character is to be found in a few of the Panama shells, which have longitudinal rays of reddish brown, while all the other specimens are of a uniform white. So far at least as the shells are concerned, it seems necessary to admit that they all may be comprised in one species; or to maintain that individuals, which cannot be distinguished from each other, belong to different species, because it is probable that they descended from distinct original stocks. But if we admit that each species in the animal kingdom was introduced by the creation of many original stocks, then the fact before us becomes intelligible and very uncommon in only one particular, viz: that the original individuals of a single species were created in very distant zoological provinoes.

On the opinion that the North American C. plana Say is identical with the Mediterranean C. unguiformis Larn., Dr. Gould remarks as follows :-

"In this opinion I have the concurrence of Mr. Sowerby. 
Deshayes observes that he can hardly think that the shell figured as Calyptrae unguiformis by Broderip in 'Trans. Zool. Soc.' I. pl. 29, f. 4, is the shell of Linnæus. He says the shell of Linnæus is distinguished by a profound notch at one extremity of the partition, and a feebler one at the other ; that the shell described by Mr. Say as Crepidula plana wants this notch, and is the shell figured by Broderip. Now it so happens that the only specimen which I am certain is entire, has this notch precisely as described, and the tooth-like process which separates the large notch from the rest of the margin is such as would be likely to be broken in almost every instance. This fact leads me to suppose that all three of the shells in question are of the same species, and should be called $C$. unguiformis."

Station.-Dans l'intérieur des coquilles univalves abandonnées; Defrance. Espèce qui a l'habitude de se mettre à l'abri dans les coquilles abandonnees; Deshayes. Inside of dead shells of Ranella vexillum, $R$. ccelata, \&c. * * * Dredged from sandy mud at a depth ranging from 4 to 10 fathoms; Cuming ! Broderip. In the aperture of other shells; Gould! In dead shells, whether or not the shells are occupied by Paguridæ. We have received the shell from Sicily in the aperture of a Murex trunculus. In Massachusetts we have found it in the aperture of Natica duplicata, of Pyrula canaliculata, P. carica; on the inside of Pecten concentricus, and of the crustacean Limulus polyphemus, \&c. In Jamaica, we found it in Mures brevifrons, $\boldsymbol{M}$. funiculatus (?), Fasciolaria tulipa, Pymula melongena, Turbo crenulatus, \&c. In Panama we found it in Murex radix, Fasciolaria granosa, Turbo saxosus, Natica sp. indet., \&c. It occurs more frequently near half tide level, but is not very narrowly limited in its vertical range.

Dr. Gould and D'Orbigny both consider the peculiarities of this shell as the effect of its position; and Orbigny ascribes the flattened form to the pressure of the organs of hermit crabs, one of which usually occupies the same habitation. 'If, however, 
these writers are correct, we ought to find the characters always graduating into those of other species, according to the position of the shell.

Habitat.-Ilva; Gualteri.

Seas of Barbary; Linnæus: also Gmelin: also Lamarck.

In nearly all the Mediterranean; Deshayes.

Mediterranean; Jay.

Bays of Tunis and Algiers; McAndrew !

Sicily; C. B. A.

Mediterranean and Seas of Senegal; Potiez and Michaud.

Maine; Mighels!

Massachusetts; Gould I also C. B. A.I

New York harbor; C. M. Wheatley!

New Jersey ; Say.

Maryland, Carolina, Georgia, and East Florida; Say!

Jamaica; C. B. A.!

I. of Chilöe and Panama; Cuming! Broderip; also Miuller.

Panama; C. B. A.!

In the United States, Maine appears to be the northern limit of the species: Dr. Mighels says, "I have never found but one individual of this species in Casco Bay [Maine]; this had located itself within the mouth of a dead Buccinum undatum." In Massachusetts, we have only found one specimen north of Cape Cod; this was on Chelsea Beach. But south of Cape Cod the species is common. In Jamaica, it is common in the Bay of Port Royal. At Panama we collected 35 specimens.

This species is thus found to inhabit the following distinct marine zoological provinces:-

1. The Mediterranean.

2. East side of North America, north of Cape Cod.

3. " " " $"$ middle regions.

JULY, 1852. 
4. The Caribbean waters.

5. West side of America, tropical shores.

6. " " " southern temperate region.

It is also common in a fossil state.

"Fossile en Italie, en Sicilie, en Morée, à Bordeaux et à Dax, dans les faluns de la Touraine:" Deshayes,

"Fossile nel Piacentine e nel Sanese;" Brocchi.

\section{Crepidula nivea. Nov. sp.}

Shell ovate-elliptic: rather thick : within snow white: with. out dingy white, sometimes with a faint tinge of brown: very irregularly concentrically more or less wrinkled, with very distinct striæ of growth: apex turned more or less to the right, moderately prominent, marginal : septum longitudinally sub. apgular, with a'deep sinus at the left and a shallow one at the right: margin thick, exhibiting striæ of growth. It closely resembles $\boldsymbol{C}$. unguiformis, but constantly differs in characters and station.

Length 1.4 inch; breadth 1 inch; height. 4 inch.

Station.-Under stones, near low water mark.

Habitat-Panama; C, B. A.!

45 specimens were collected on the reef.

\section{Crepidula osculans. Nov. sp.}

Shell elliptical: pale horn color, subtransparent: surface minutely decussated with numerous very small radiating and concentric ridges: apex subterminal, very prominent, not marginal, with the nuclear portion smoath, shining, transparent and slightly directed to the right: septum but little above the margin, extremely narrow or linear, extending around the posterior part of the shell : margin very thin. In some respects, this species is allied to Pileopsis.

Length .14 inch; breadth .1 inch; height .045 inch. 
Station.-Unknown.

Habitat.-Panama ; C. B. A.!

Only 1 specimen of this extraordinary species was obtained.

\section{Crepidula rostrata. Nov. sp.}

Shell very convex, irregularly elliptic: livid brown, sometimes with pale ill-defined spots : irregularly somewhat corrugated both radiately and concentrically: apex very acute and prominent, rostriform, very distant from but extending beyond the posterior margin, slightly directed to the right: septum far within the margin, planulate, usually very oblique to the plane of the aperture : margin thin, irregular.

Length .48 inch; breadth .3 inch; height .29 inch.

Station.-Unknown.

Habitat.-Panama; C. B. A.!

5 specimens were obtained in different stages of growth.

\section{Family-FISSURELLID A.}

\section{Fissurella aequalis.}

\section{Synonymy.}

Fissurella aqualis Sowb. in Proc. Zool. Soc. Lond. p. 127. Nov. 1834. Müll. Synop. Nov. Test. Viv. p. $158 . \quad$ May 1836. Sowb. Conch. Ill. No. 49. pl. 76. f. 56. 1841. Reeve Conch. Icon. pl. 8. f. 55.

Dec. 1849.

Station.-On dead shells in from 6 to 10 fathoms; Cuming! Sowerby : also Reeve.

Habitat.-St. Elena; Cuming ! Sowerby : also Reeve. Panama; C. B. A.!

5 specimens were obtained. 


\section{Fissureila alta. Nov. sp.}

Shell subconic, high : dingy white, often more or less covered with broad ashy black rays, which may be seen through the shell: with prominent radiating ribs, of which the alternate ones are excessively developed, and intermediate small raised lines; with many concentric ridges, which are less prominent than the larger radiating ribs, and more so than the others: surnmit nearer to and somewhat inclined towards the anterior extremity: fissure small, ovate-elliptic: margin pectinated by the radiating ribs.

The following are the dimensions of a very large and high shell and of another of average size :

Height .42 inch; length .55 inch; breadth .41 inch.

". .22 " " 42 " 40 " 42 "

Station.-Unknown.

Habitat.-Panama; C. B. A.I

26 speçimens were obtained.

356. Fissurella macrotrema.

\section{Synonymy.}

Fissurella macrotrema Sowb. in Proc. Zool. Soc. Lond. p. 125. Nov. 1834. \begin{tabular}{rrr}
\hline Müll. Synop. Nov. Test. Viv. p. 155. May 1836. \\
\hline Sowb. Conch. Ill. No. 33. pl. 74. f. 41. & 1841. \\
\hline & Chenu. Il. Conch. pl. 1. f. 14. & 1843. \\
\hline & Reeve Conch. Icon. pl. 5. f. 31. & Aug. 1849.
\end{tabular}

Station.-Under stones on the shore; Cuming ! Sowerby.

Habitat.-Gallapago Is. and Real Llejos; var's at Lobos I. and Lambeyeque, Peru; Cuming ! Sowerby: also Müller.

Gallapago Is. ; Cuming! Reeve.

Taboga; C. B. A. 1

We collected 5 specimens, which are somewhat narrower than the figures in Sowerby and in Reeve. 


\section{Fissurella microtrema.}

Synonymy.

Fissurella microtrema Sowb. in Proc. Zool. Soc. Lond. p. 125. Nov. 1834. - Müll. Synop. Nov. Test. Viv. p. 156. May 1836.

$\longrightarrow$ Chenu Ill. Conch. pl. 1. f. 11. Orb. Voy. Amer. Merid. Moll. p. 473. 1843. Reeve Conch. Icon. pl. 7. f. 44. Dec. 1840.

The shells before us seem to be intermediate between this species and $F$. rugosa Sowb., as these species are figured by Sowerby and by Reeve. We are indebted to Mr. Cuming for specimens which enable us to determine the species.

Station.-Under stones at low water; Cuming ! Reeve.

Habitat.-Real Llejos; Cuming I Sowerby : also Reeve. West Columbia; Cuming! in sched.

Panama ; C. B. A. 1

We obtained 10 specimens in various stages of growth.

\section{Fissurella mus.}

\section{Synonymy.}

Fissurella mus Reeve Conch. Icon. pl. 16. f. 120.

Aug. 1850.

Var. Two of our specimens differ from the type in having the fissure shorter and the region around it more elevated.

Station.-Unknown.

Habitat.-Unknown; Reeve.

Panama; C. B. A.!

8 specimens were collected.

\section{Fissurella nigropunctata.}

\section{Synonymy.}

Fissurella nigropunctata Sowb.in Proc.Zool. Soc. Lond.p.125. Nov. 1834. Müll. Synop. Nov. Test. Viv. p. 155. May 1836. 
Fissurella nigrapunclata Sowb. Conch. Ill. No. 32. pl. 75. f. 51. 1841. Reeve Conch. Icon. pl. 4. f. 8. Aug. 1849.

Station.-Under stones on the shore; Cuming I Sowerby : also Reeve.

Our specimens were found on rocks at and below half tide level. Some of them have their outlines singularly modified by the surface of the rugged rocks on which they were living.

Habitat.-Gallapago Is., and Lobos I.; Cuming! Sowęrrby : also Reeve: also Muiller.

Gallapago Is. ; Jay.

Taboga; C. B. A.!

We collected 95 specimens. Most of them are elongated like the figure in the Conch. Illust., and are narrower than the figure in the Conch. Icon.

\section{Fissurella ostrina.}

Synonymy.

Fissurella ostrina Reeve Conch. Icon. pl. 14. f. 106.

Aug. 1850.

Station.-Unknown,

Habitat.-Unknown; Reeve.

Panama; C. B. A.!

3 specimens were found near Panama.

\section{Fissurella virescems.}

Synonymy.

Fissurella virescens Sowb. in Proc. Zool. Soc. Lond. p. 125. Nov. 1834. - Müll. Synop. Nov. Test. Viv. p. 154. May 1836. - Sowb. Conch. Illust. No. 31. pl. 73. f. 37. 1841. - Reeve Conch. Icon. pl. 4. f. 12. Aug. 1849.

Station.-In exposed situations at low water; Cuming ! Sowerby. In exposed situations on rocks at low water; Cuming! Reeve.

Our specimens were found on a ledge of rather smooth rocks, between half tide and low water mark, in a place somewhat exposed to the sea. 
Habitat,-Panama; Cuming! Sowerby : also Reeve: Müller. Mazatlan; Melchers! Menke.

Mazatlan ; Lt. Green! Mus. Essex Inst.

Panama; Jay.

Panama; C. B. A.I

We collected 142 specimens on a ledge of rocks nearly three miles east of Panama.

\section{Siphonaria characteristica.}

Synonymy.

Siphonaria characteristica Reeve in Proc. Zool. Soc. Lond.p. 49. Mar. 1842. Reeve Conch. Syst. pl. 138. f. 3.

Station.-On rocks above and below half tide level.

Habitat.-Bay of Panama; Cuming! Reeve.

Bay of Panama; Jay.

Taboga; C. B. A. 1

70 specimens were collected.

\section{Siphonaria costata.}

Synonymy.

Siphonaria costata Sowb. in Proc. Zool. Soc. Lond, p. 6. Jan. 1885.

Station.-On rocks in exposed situations at low water; Cum. ing ! Sowerby.

Habitat.-Guacomayo; Cuming! Sowerby.

Guacomayo; Jay.

Panama; C. B. A.!

Only 1 specimen was found.

\section{Siphonaria gigas.}

Synonymy.

Siphonaria gigas Sowb. Tank. Catal. App. p. 6. No. 808.1825. Reeve Conch. Syst. pl. 138. f. 6. 
Station.-On rocks above and below half tide level.

Habitat.-Panama; Sowerby.

Peru; Voyage of the Venus.

Gallapago Is.; Jay.

Taboga; C. B. A.

220 specimens were collected.

Nearly one half of the specimens, which we have included in this species, are intermediate between this and S.characteristica. There is so little constancy in the two forms, that the distinction is a source of much perplexity.

\section{Siphonaria maura.}

Synonymy.

Siphonaria maura Sowb. in Proc. Zool. Soc. Lond. p. 7. Jan. 1835. Reeve Elem. Conch. pl. 24. f. 144 ?

$1848 ?$

Station.-On rocks; Cuming I Sowerby. Our specimens were found on ledges of rocks, mostly above half tide level.

Habitat.-Panama; Cuming! Sowerby.

Panama; C. B. A.I

200 specimens were collected.

\section{Siphonaria pica?}

Synonymy.

Siphonaria pica (') Sowb. in Proc. Zool. Soc. Lond. p. 6. Jan. 1835.

Slation.-On rocks in exposed situations; Cuming I Sowerby.

Habitat.-Acapulco; Cuming ! Sowerby. '

Panama; Jay.

Panama; C. B. A.I

3 specimens were found.

Is not Mr. Sowerby in error when he represents Mr. Cuming as having made collections at Acapulco? 


\section{Lottia patina ?}

Synonymy.

Acmoca patina (?) Rathke in Esch. Zool. Atlas. Heft. V.

p. 19. pl. 24. f. 7, 8 .

1833.

Station.-On and under stones at the low water mark of neap tides.

Habitat.-Mazatlan; Lt. Green! Mus. Essex Inst.

Panama; C. B. A. !

34 specimens were collected on the reef.

Var. $a$ has only linear pale rays on a dark olivaceous ground, and the margin is of a uniform blackish brown: the radiating striæ are coarser than in the type.

368. Lottia - Sp. indet. $a$.

A small suborbicular conical thin shell.

Station.-Under stones near half tide level.

Habitat.-Panama ; C. B A.1

45 specimens were collected.

369. Lottia ㄴ.. Sp. indet. $b$.

20 specimens were taken with the preceding.

370. Lottia - Sp. indet. $c$.

11 specimens of this minute species were collected at Panama.

Family-PATELLID $\$$.

371. Patella (?) . Sp. indet. a.

Station.-On rocks not far from half tide level.

Habitat.-Panama; C. B. A.!

16 specimens were collected. 


\section{Chiton clathratus.}

Synonymi.

Chiton clathratus Reeve Conch. Icon. pl. 18. P. 113.

Apr. 1847.

Station.-Under stones near low water mark.

Habitat.-Unknown; Reeve.

Panama; C. B. A.! .

12 specimens were found.

\section{Chiton dispar.}

Synonymy.

Chiton dispar Sowb. in Proc. Zool. Soc. Lond. p. 58.

Mar. 1832.

Müll. Syn. Nov. Test. Viv. p. 168.

1836.

- Müll. Syn. Nov. Test. Viv. p. 168. 2 Lam. An. sans Vert. VII. 511. No. 50. (Desh. ed.) 1838.

—- Sowb. Conch. Ill. No. 47. pl. 41. f. $25 . \quad 1841$.

- Lam. An. sans Vert. III. Pt. 1.p. 188. No. 50.

(Desh. ed. tert.)

- Apr. 1841.

- Reeve Conch. Icon. pl. 18. f. 96.

Apr. 1847.

Station.-Under stones: Cuming 1 Sowerby: also Reeve.

Our specimens were found under stones near the low water mark of neap tides.

Habitat.-"I. of Saboga;" Ouming! Sowerby.

Gulf of Panama; Deshayes.

"I. of Saboga, Panama;" Cuming! Reeve.

Panama, and Taboga; C. B. A.!

This species is common. We collected about 100 specimens, many of which have been destroyed by rats.

\section{Chiton luridus?}

Synonymy.

Chiton luridus Sowb. in Proc. Zool. Soc. Lond. p. 26.

Feb. 1832.

1836.

- Lam. An. sans Vert. VII. 495. No. 13. (Desh. ed.) 1838. 
ChitoN.

Chiton luridus Lam. An, sans Vert. III. Pt. 1. p. 182. No. 13. (Desh. ed. tert.)

- 1839.

\begin{tabular}{lr}
- Sowb. Conch. Ill. No. 99. pars. pl. 40. f. 20. & 1841. \\
\hline Reeve Conch. Icon. pl. 15. f. 85. & Mar. 1847.
\end{tabular}

Our specimens differ from $C$. luridus, as described by Sowerby and by Reeve, in having the granules of the terminal valves and of the lateral areas rather sparsely scattered, instead of being crowded.

Station.-Attached to stones at a depth of 5 fathoms; Cum. ing! Sowerby : also Reeve.

Our specimens were found under stones at low water mark.

Habitat.-St. Elena; Cuming! Sowerby : also Reeve.

St. Elena; Jay.

Panama; C. B. A.l

3 specimens were found.

\section{Chiton pulchellus.}

Synonymy.

Chiton pulchellus Gray Spicil. Zool.

1828.

Orb. Voy. Amer. Merid. Moll. p. 488.

1843.

$-$ Reeve Conch. Icon. pl. 23. f. 153.

May 1847.

Slation.-30 or 40 fathoms depth; Orbigny.

Under stones, which were lying half buried in sand near the low water mark of the neap tides.

Habitat.-Arica, in Peru; W. V. Hennah! Reeve.

Islay; Orbigny.

Panama and Taboga ; C. B. A.!

80 specimens were collected.

\section{Chiton Stokesii.}

Synonymy.

Chiton Stokesii Brod. in Proc. Zool. Soc. Lond. p. $25 . \quad$ Feb. 1832. 
Chiton Stokesii Müll. Syn. Nov. Test. Viv. p. 162.

Lam. An. sans Vert. VII. 510 No. 49. (Desh. ed.) 1838.

- Lam. An. sans Vert. III. Pt. 1. p. 188. No. 49. (Desh. ed. tert.)

- 1841.

\begin{tabular}{ll}
- Sowb. Conch. Ill. No. 20. pl. 41. f. 24. & 1841. \\
\hline Orb. Voy. Amer. Merid. Moll. p. 486. & 1843.
\end{tabular}

- Reeve Conch. Icon. pl. 1. f. 4.

Mar. 1847.

Station.-On stones at low water; Cuming I Broderip. Under stones at low water; Cuming! Reeve.

Our specimens were found under stones near the low water of neap tides.

Habitat.-Port St. Elena, and Panama; Cuming! Broderip.

Seas of South America; Deshayes.

Columbia; Sowerby : also Jay.

Arica and Islay; Orbigny!

St. Elena; Cuming | Reeve.

Taboga and Panama; C. B. A.I

We collected about 40 specimens, many of which have been destroyed by rats. The species is very common.

Family_OSTR AID Æ.

\section{Anomia lampe.}

Synonymy.

Anomia lampe Gray in Proc. Zool. Soc. Lond. p. 117.

- Gray in Catal. Anom. Brit. Mus. p. 19.

Nov. 1849.

1850.

Station.-In 60 fathoms water; Major Rich! Gould MSS. It also occurs at low water mark.

Ilabitat.-California; Gray.

La Paz and Monterey, Calif.; Major Rich! Gould MSS.

Panama; C. B. A.!

Only 1 specimen was obtained. The specimen obtained from 60 fathoms water by Major Rich was taken at Monterey. One from La Paz in Mus. Gould is of enormous size. 
378. Anomia tenuis. Nov. sp.

Shell orbicular: flat, extremely thin: white, subtransparent, pearly: externally somewhat uneven: upper scar large, rounded, with the lower side arcuated: two lower scars small, circular, equal: anterior one nearly entering the arcuation of the upper scar; posterior one near the other, with the upper margin as high as the centre of the other.

Diameter about .85 inch.

Station.-Near low water mark.

Habitat.-Panama; C. B. A.!

3 specimens were obtained.

\section{Anomia - Sp. indet. $a$.}

A very small yellow shell with the convex valve excessively convex, and the margin lobate. Although only 1 valve was found, it is obvious that it belongs to a very distinct species.

\section{Ostrea —. Sp. indet. $a$.}

Rather large and ovate; with the upper valve radiately corrugated, with many notches on both sides of the hinge: lower valve attached to a ledge of rock by the whole of its surface: on this account it is rarely possible to detach, a specimen entire. It occurs more commonly near half tide level. It is rather common, but not abundant on the reef at Panama. We collected only 6 specimens. It is an edible species of excellent flavor. During the recess of the tide the natives open the shells on the rocks, without detaching the lower valves, and collect the soft parts in a calabash.

\section{Ostrea - Sp. indet. $b$.}

Rather large and solid, with both valves strongly notched on both sides of the hinge: surface without sculpture other than JULY, 1852. 
the incremental striæ: nacre extremely brilliant, with delicate changeable colors.

Attached to ledges of rock by the greater part of the lower valve. It occurs near half tide level.

It is not common: we collected only 3 specimens on the reef at Panama.

382. Ostrea —- Sp. indet. $c$.

Synonymy.

9. Columbiensis Hanley, P. Z. S. Lond. p. 107.

Oct. 1845.

Rather small, more or less pentangular, and short but not plicated.

Attached to stones, rocks, and other shells, near half tide level: the lower valve is attached by rather more than half of its surface, and then abruptly rises from the attached part so as to form a deep cavity.

O. Columbiensis Hanl. was found by Mr. Cuming attached to rocks at half tide at St. Elena. At Panama our shell is not rare, although we took only 15 specimens.

\section{Ostrea —. Sp. indet.}

Like 0 . borealis.

Usually occurs in clusters.

It was brought from some place near Panama which we did not visit. We obtained 35 specimens. The flavor is superior to that of 0 . virginica or 0 . borealis. They were sold in $\mathrm{Pa}$ nama at a dime each.

384. Ostrea H, Sp. indet. e.

A small plicated species. The animal has a bitter flavor. Attached to rocks and stones from three quarters to one quarter tide level. A small var. grows on Nerita scabricosta.

This species covers many parts of the reef at Panama in great profusion. We collected 330 specimens. 
PECTEN.

Family-PECTENID ZE.

\section{Spondylus Lamarekii ?}

Synonymy.

Spondylus Lamarckii (?) Chenu Ill. Conch. p. 6. pl. 9. f. 4.

(?) Sowb. Thes. Conch. p. 425. No. 21.

pl. 85. f. 20.

1847.

Our specimens being old, with the sculpture eroded, we are unable to determine confidently what the species is, it being unfortunately the custom in this genus and in Chama to describe and figure little more than those exterior characters which are very rarely found in perfection. One of the most permanent characters of this species is the broad deep red purple finely wrinkled limb of the otherwise white interior.

Station.-Unknown.

Habilat.-La Paz; Lt. Green 1 Gould MSS. Bay of Panama; C. B. A.!

At Taboga we found a large pile of odd valves of this species, which the natives had taken in the bay.

\section{Spondylus —- Sp. indet. $a$.}

Brown, with a narrow white margin. Only one very young specimen was found. Hab. Panama:

\section{Pecten Inca.}

Synonymy.

Pecten tumidus Sowb. (non Turt. nec Zeiten) in Proc. Zool. Soc. Lond. p. $109 . \quad$ - - July 1835.

- ventricosus Sowb. Thes. Conch. p. 51. No. 19. pl. 12. f. 18, 19, 26. - $\quad$ - $\quad 1842$. - Inca Orb. Voy. Amer. Merid. Moll. p. 663. Station.-In sandy mud at from 6 to 10 fathoms. 
Habitat.-St. Elena and Salango; Cuming! Orbigny.

St. Elena; Sowerby.

Calapan, Philippines; Cuming! Sowerby; "young specimens."

West Columbia; Jay.

Taboga and Panama; C. B. A.!

Great numbers of odd valves, much worn, were seen at Taboga; but we did not learn the station of the species, and collected only 8 odd valves.-Probably the young shells from the Philippines are the young of some allied but distinct species.

\section{Pecten Tumberensis.}

\section{Synonymy.}

Pecten aspersus Sowb. (non Lam.) in Proc. Zool. Soc.

Lond. p. 110.

July 1835.

Sowb. Thes. Conch. p. 51. No. 16. pl.

19. f. 198-9.

1842.

Hanley Descr. Catal. p. 271.

1845 ?

Tumbezensis Orb. Voy. Amer. Merid. Moll. p. 663.

1846.

Station.-Soft mud at the depth of 5 fathoms: Cuming! Sowerby.

Ilabitat._Tumbez, in Peru; Cuming! Sowerby: also Orbigny.

Peru; Hanley.

Mazatlan; Melchers! Menke.

Panama; C. B. A.!

Only 2 odd valves were found.

\section{Lima angulata.}

Synonymy.

Lima angulata Sowb. in Proc. Zool. Soc. Lond. p. 23.

Feb. 1843.

Sowb. Thes. Conch. p. 86. No. 12. pl, 22.

f. 39,40 .

1843.

Orb. Voy. Amer. Merid. Moll. p. 653.

1846. 
AVICULA.

Station.-Sandy mud, 12 to 20 fathoms; Cuming! Sowerby.

Habitat.-Panama and Bay of Caraccas ; Cuming I Sowerby: also Orbigny.

Panama; C. B. A. 1

, We found 1 entire shell and 3 odd valves.

\section{Lima Pacifica.}

Synonymy.

Lima arcuata Sowb. (non Geinitz 1840) Thes, Conch. p. 86.

No. 15. pl. 22. f. 41-2. - $\quad$ - $\quad$ - $\quad$ - 1843. Hanley Descr. Catal. p. 268.

1845

Station.-Under stones at the low water mark of the spring tides.

Habitat.-Guayaquil and Panama; Cuming I Orbigny.

Panama; Hanley.

Panama; C. B. A.1

"At Lord Hood's I, under coral rocks; at Panama, in sandy mud; at Guayaquil Bay; at Guacomayo, under stones, \&c., by Mr. Cuming." Sowerby.

3 specimens were found alive on the reef.

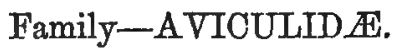

\section{Avicula margaritifera?}

Under the name of $A$. margaritiferia are included several kindred but distinct types. It would be of great service to the general subject of the geographical distribution of marine species, if some one would collect authentic materials, and investigate the peculiarities of the local types.

Station.-In the crevices of rocks near low water mark.

Habitat.-Taboga; C. B. A.1

We found only 2 living, rather young, specimens. Probably JUL.X, 1852. 
these are identical with the species which occurs abundantly in some parts of the Bay of Panama, and from which pearls are procured.

\section{Avicula sterna.}

Synonymy.

Avicula sterna Gould Proc. Bost. Soc. Nat. Hist. p. 93. Nov. 1851.

Station.-Attached to a small speciẹs of Gorgona, at the low water mark of the spring tides.

Habitat.-Panama; E. Jewett! Gould MSS.

Panama; C. B. A.!

10 specimens were collected on the reef.

393. Perma —. Sp. indet. $a$.

Station.-Under stones and in the crevices of rocks at low water mark.

Habitat.-La Paz; Lt. Green! Gould MSS.

Panama; C. B. A.I

130 specimens were collected on the reef.

994. Perna - Sp. indet. $b$.

With the preceding: 30 speoimens were collected.

Family-MYTHID 无.

\section{Pinna maura.}

Synonymy.

Pinna maura Sowb. in Proo. Zool. Soc. Lond. p. 84.

Hanloy Descr. Catal. p. 255.

June 1835.

$1845 ?$

Station.-Muddy banks; Cuming! Sowerby.

Habitat.-Panama; Cuming! Sowerby.

Panama; Hanley ! 
Panama; C. B. A.!

Only 1 specimen was found.

\section{Pinna tuberculosa.}

Synonymy.

Pinna tuberculosa Sowb. in Proc. Zool. Soc. Lond. p. 84. June 1835. Hanley Desc. Catal. p. 255.

Station.-Muddy banks; Cuming! Sowerby.

We found it in crevices of rocks, near low water mark.

Habitat.-Panama; Cumingl Sowerby.

Panama; Hanley.

Panama; C. B. A.I

4 specimens were found on the reef.

397. Mytilus - Sp. indet. $a_{\text {o }}$

Station,-Unknown.

Habitat.-Panama; C. B. A.I

1 specimen was obtained.

398. Lithodomus —. Sp. indet. $a$.

Station.-In thick shells, between half tide and low water mark.

Habitat.-Panama ; C. B. A. 1

20 specimens were collected on the reef.

\section{Modiola semifusca?}

Synonymy.

Modiola semifusca (?) Lam. An. sans Vert. No. 11.

Sowb. Gen. pl. - f. 6.

(?) Lam. Ȧn. sans Vert. VII. 22. No. 11.

(Desh. ed.) - - - - - 1836.

Mytilus Guiaënsis Küst. (an Lam. ?) Conch. Cab. pl. 1. f. 7. 1840. 
Station.-Unknown.

Elabitat.-Panama; C. B. A.I

A few dead shells were found in several places near Panama, and fine specimens were procured at the fruit shanty. 35 specimens were obtained.

400. Modiola - Sp. indet. $a$.

Station.-In the crevices of rocks, between half tide and low water mark.

Habitat.-Panama and Taboga : C. B. A.!

6 specimens were obtained.

401. Modiola —. Sp. indet. $b$.

Station.-In the crevices of rocks, between half tide and low water mark.

Habitat.-Taboga; C. B. A.1

35 specimens were collected.

402. Modiola - Sp. indet. $c$.

Station.-Unknown.

Habitat.-Panama; O. B. A.I

4 specimens were obtained.

403. Modiola - Sp. indet. $d$.

Station.-Unknown.

Habitat.-Panama; C. B. A.!

2 specimens were found.

404. Modiola - Sp. indet. e.

Station.-In soft, partly calcareous stones, not far from half tide level. 
CHAMA.

Habitat.-Panama; C. B. A.1

2 specimens were obtained.

Family-CHAMID \&.

405. Chama Buddiana. Nov. sp.

Shell orbicular or subtriangular: exterior surface and inner margins purplish red, with the spines pure white: surface uneven, with interrupted radiating striø; upper valve ornamented with a few radiating series of short thick triangular vaulted spines: lower valve attached by about two-thirds to three-quarters of its surface, the rest being like the upper valve, but with the dentiform spines smaller: within both valves are deeply and finely crenulated at the junction of the white surface and red margin: beak submarginal. Easily distinguished from $C$. Pacifica and $C$. Broderipii by the small thick dentiform triangular white spines.

Diameter about 3 inches.

Station.-On ledges of rocks, a little above low water mark. The lower valve is so firmly attached as to render it difficult to obtain specimens entire without the use of mineralogical tools.

Habitat.Guaymas; Lt. Green! Mus. Essex Inst. Panama; C. B. A. I

6 specimens were obtained.

Named in honor of Dr. B. W. Budd of New York city.

\section{Chama corrugata ?}

\section{Synonymy.}

Chama corrugata Brod. in Proc. Zool. Soc. Lond. p. 150. Dec. 1834. Brod. in Trans. Zool. Soc. Lond. I. 305. pl. 31. f. 7. - - - - - 1835. $\begin{array}{rr}- \text { Hanley Descr. Catal. p. } 220 . & 1845\} \\ - \text { Reeve Conch. Icon. pl. 2. f. 9. } & \text { Dec. } 1846 .\end{array}$

Possibly our shell may be a large specimen of $C$. PanamenJULY, 1852. 
sis Reeve. Having only 2 odd valves with an eroded surface, we are unable to determine the species with confidence.

Station.-Attached to stones at low water; Cuming! Broderip. Under stones; Cuming! Reeve.

Habitat.-Real Llejos; Cuming! Broderip: also Reeve.

Central America; Hanley.

Real Llejos; Jay.

Panama; C. B. A.!

We found only 2 valves.

\section{Chama cchinata.}

Synonymy.

Chama echinata Brod. in Proc. Zool. Soc. Lond. p. 150. Dec. 1834. Brod. in Trans. Zool. Soc. Lond. p. 305. pl. 39.

f. 5-7. - - - - - - 1835 . Reeve Conch. Icon. pl. 7. f. 35. junior. Jan. 1847.

Station.-At low water, attached to rocks; Cuming! Broderip: also Reeve. On rocks near low water mark.

Habitat.-Puerto Portrero; Cuming! Broderip : also Reeve. Panama; C. B. A.!

15 specimens were obtained.

Family-ARCID AE.

\section{Nucula Elenensis.}

\section{Synonymy.}

Nucula Elenensis Sowb. in Proc. Zool. Soc. Lond. p. 198. Dec. 1832. \begin{tabular}{rr}
- Müll. Syn. Test. Viv. p. 191. & 1836. \\
\hline Sowb. Conch. Ill. No. 19. pl. 15. f. 14. & 1841. \\
\hline Reeve Conch. Syst. pl. 85. f. 14. & Sept. 1841. \\
\hline Hanley Descr. Catal. p. 169. & 1845 ?
\end{tabular}

With some hesitation we have referred our specimens to this species, although we cannot detect the "marginibus crenulatis." 
NUCULA.

Station.-Sandy mud, at a depth of 6 fathoms; Cuming! Sowerby.

Habitat._St. Elena; Cuming ! Sowerby : also Miuller.

West Columbia; Hanley.

Panama; C. B. A.I

20 odd valves were found.

\section{Nucula exigua.}

Symonymy.

Nucula exigua Sowb. in Proc. Zool. Soc. Lond. p. 198. Dec. 1832.

- Müll. Syn. Test. Vir. p. 192.

1836.

1841.

Sowb. Conch. Ill. No. 34. pl. 16. f. 24.

1845

Orb. Voy. Amer. Merid. Moll. p. 625.

1846 .

Station.-Sandy mud, in 9 fathoms ; Cuming I Sowerby :

Habitat.-Bay of Caraccas; Cuming ! Sowerby : also Müller: also Orbigny.

West Columbia; Hanley.

Panama; C. B. A.!

1 valve only was found.

\section{Nucula polita.}

Synonymy.

Nucula polita Sowb. in Proc. Zool. Soc. Lond. p. $198 . \quad$ Dec. 1832.

- Lam. An. sans Vert. VI. 507. No. 8. (Desh. ed.) 1835.

- Müll. Syn. Test. Viv. p. 190.

— Lam. An. sans Vert. II. 660. No. 8. (Desh. ed. tert.) 1839.

- Sowb. Conch. Ill. No. 16. pl. 15. f. 11.

- Reeve Conch. Syst. pl. 85. f. 11. Sept. 1841. - Hanley Descr. Catal. p. 169.

Station.-A single specimen of this very beautiful species was dredged up in sand from a depth of 7 fathoms; Cuming! Sowerby. 
Habitat.-Panama; Ouming! Sowerby : also Mtiller.

Panama; Deshayes : also Hanley.

Panąma ; O. B. A.l

10 odd valves were found.

\section{Pectunculus assimilis.}

\section{Synonymy.}

Pectunculus assimilis Sowb. in Proc. Zool, Soc. Lond. p. 196. Dec. 1832. \begin{tabular}{rr}
1836. \\
\hline Mëll. Syn. Test. Viv. p. 189. & 184. \\
\hline Orb. Voy, Amer. Merid. Moll. p, 629. & 1846.
\end{tabular}

In the number, width, and form of the cross bands of brown our specimens are so variable that no two are alike, and two of them have most of the ground color of a greyish blue. In respect of coloring, therefore, the species does not appear to be well distinguished from $P$. inequalis. Nor is the distinction in sculpture much more constant.

Station.-In sandy mud and gravel, in from 8 to 12 fathoms; Curning ! Sowerby : also Reeve.

Our specimens were found under stones, in calcareous gravel, between one quarter tide and low water mark.

Habitat.-Puerto Portrero, Bay of Guayaquil, Central America; Cuming! Sowerby: also Müller: also Reeve: also Orbigny.

Guayaquil ; Jay.

Mazatlan; Lt. Green 1 Gould MSS.

Panama; C. B. A.!

20. specimens were collected on the reef.

A common ambiguity again appears in Mr. Sowerby's statement; since the Bay of Guayaquil (and Puerto Portrero?) is not in Central America, is the latter mentioned as a third locality? 
ARCA.

\section{Pectunoulus maculatus ?}

Synonymy.

Pectunculus maculalus Brod. in Proc. Zool. Soc. Lond. p. 126. June 1832. Reeve Conch. Icon. pl. 1. f. 4.

Feb. 1843.

Station.-In fine gravel in 11 fathoms water; Cuming! Broderip.

Habitat -Puerto Portrero; Cuming I Broderip : also Reeve. Panama; C. B. A.I

We obtained only one specimen. It is nearly covered with very large irregular spots and radiating lines of dark red; it is also very convex at the umbones, and in both of these characters appears to differ from the $P$. maculatus as described by $\mathrm{Mr}$. Broderip, and as figured by Mr. Reeve.

\section{Arca alternata.}

Synonymy.

Byssoarcas alternata Sowb. in Proc. Zool. Soc. Lond. p. 17. Feb. 1833.

\begin{tabular}{rrr}
\hline Arca Müll. Syn. Test. Viv.p. 184. & 1836. \\
\hline & Reeve Conch. Icon. pl. 13. f. 88. & Apr. 1843. \\
\hline Hanley Descr. Catal. p. 156. & 1845 ! \\
\hline Orb. Voy. Amer. Merid. Moll. p. 638. & 1846.
\end{tabular}

Station.-Attached to stones, on a rocky bottom, at the depth of 12 fathoms; Cuming ! Sowerby : also Reeve.

Habitat.-West Columbia; Cuming! Sowerby : also Reeve. Equador; Cuming ! Orbigny.

West Columbia ; Hanley.

Mazatlan ; E. Jewett I Gould MSS.

Panama and Taboga ; C. B. A.I

4 specimens were collected.

\section{Arca aviculoides?}

Synonymy. .

Arca auriculata Sowb. in Proc. Zool. Soc. Lond. p. 20. Feb. 1833. JULY, 1852. 
Arca aviculoides Reeve Conch. Icon. pl. 10. f. 63.

Mar. 1844.

Station.-Muddy bottom at the depth of 10 fathoms; Cuming I Sowerby : also Reeve.

Habitat._St. Elena; Cuming! Sowerby : also Reeve.

Panama; C. B. A.I

1 specimen was obtained, which is too young to be confdently determined without a series.

\section{Arca emarginata.}

Synonymy.

Arca emarginata Sowb. in Proc. Zool. Soc. Lond. p. 20. Feb. 1833.

\begin{tabular}{rr} 
& 1836. \\
\hline Müll. Syn. Test. Viv. p. 180. & Jan. 1844. \\
Reeve Conch. Icon. pl. 4. f. 26. & 1845 ? \\
Hanley Descr. Catal. p. 161. & 1846.
\end{tabular}

Slation.-Sandy mud at the depth of 6 or 8 fathoms; Cum. ing ! Sowerby: also Reeve.

Habitat.--Real Llejos, Atacamas, Xipixapi, Panama, and Gulf of California; Cuming! Sowerby: also Reeve.

Atacama, Xipixapi, and Panama; Cuming! Orbigny.

Central America; Hanley. Panama; C. B. A.!

3 specimens were obtained.

\section{Area gradata.}

\section{Synonymy.}

Arca gradata Brod. and Sowb. in Zool. Journ. IV. 365.

1829.

—— Gray in Zool. Beech. Voy. p. 152. pl. 43. f. 1. 1839.

- Hanley Descr: Catal. p. 155. Apr. 1844. Orb. Voy. Amer. Merid. Moll. p. 636. 
Station.-Attached to stones; Cuming ! Reeve.

Our specimens were found under stones near low water mark.

Habitat.-Mazatlan; Broderip: also Beechey's Voyage.

St. Elena; Cuming ! Reeve : also Orbigny.

St. Elena; Jay.

Mexico; Hanley.

Santa Barbara ; E. Jewett! Gould MSS.

Taboga; C. B. A.I

3 specimens were found.

\section{Arca grandis.}

Synonymy.

Area grandis Brod. et Sowb. in Zool. Jour. IV. 36.5.

1829.

Reeve Conch. Icon. pl. 1. f. 4.

Dec. 1843.

Hanley Deser. Catal. p. 160.

1845 ?

Orb. Voy. Amer. Merid. Moll. p. 637.

1846 .

Slation.-Our specimens were found half buried in mud and small algæ, under trees, a little above half tide level.

Habitat.-Unknown; Broderip.

Real Llejos, Bay of Guayaquil, \&c., Western Coast

of S. America; Cuming! also Hinds I Reeve.

Guayaquil; Fontaine! Orbigny.

Panama; Jay.

Panama: C. B. A.!

13 specimens were obtained. This species is used by the natives for food. A single valve taken from a heap of the shells of edible mollusks weighs $24 \mathrm{lbs}$.

\section{Arca mutabilis.}

Synonymy.

Byssoarca mutabilis Sowb. in Proc. Zool. Soc. Lond. p. 17. Feb. 1833.

Arca

Reeve Conch. Icon. pl. 13. f. 85.

Apr. 1844.

Hanley Descr. Catal. p. 156. 
Station.-Under stones; Cuming! Sowerby : also Reeve.

Our specimens were found under stones and in the crevices of rocks, near low wațer mark.

Habitat.-I. of Plata; Cuming! Sowerby: also Reeve: also Orbigny.

West Columbia; Hanley.

I. of Plata; Jay.

Panama and Taboga; C. B. A.!

70 specimens were collected; among them are some remarkable varieties of form.

\section{Area (Byssoarca) pholadiformis. Nov. sp.}

Shell extremely elongated, subcylindrical, contracted anteriorly, very inequilateral: inferior margin a little irregular, somewhat excurved, scarcely gaping for the passage of the byssus: posterior margin very oblique, moderately excurved : anterior margin well rounded: dingy white: surface very finely and closely fimbriated, with the concentric ridges larger except above the posterior angle of the umbo, on which the concentric ridges are lamellar : with the intersections nodular and deeply marked beneath with the arcuate strix of growth: umbones flattened, with a very prominent and very oblique posterior angle, from which the radiating ribs divaricate: beaks small: area of ligament linear, nearly concealed : margins of the interior finely crenulate; teeth obsolete at the middle of the series, at the ends divaricate. The sculpture is like that of $A$. divaricala Reeve.

Length 1.25 inch; height .53 inch; breadth .48 inch.

Station.-In soft stones, near low water mark.

Habitat.-Taboga; C. B. A.!

2 specimens of this extraordinary shell were obtained. 


\section{Arca Reevenma.}

Symonymy.

Arca Helblingii Reeve (non Brug.) Conch. Icon. spec.

90 pars. pl. 14. f. 90 ? - - Apr. 1844.

Reeveana Orb. Voy. Amer. Merid. Moll. p. 635.

1846.

Station.-Under stones at low water; Ouming ! Reeve.

Our specimens were found in the same situation.

Habitat.-St. Elena, Monte Christi ; Cuming I Reeve.

Payta; Fontaine! Orbigny.

Panama; C. B. A.l

9 specimens were collected : one of them is nearly 4 inches long. Mr. Reeve mentions also I. Corregidor, Philippines, where probably the true $A$. Helblingii was obtained.

\section{Arca reversa.}

Synonymy.

Arca reversa Sowb. in Proc. Zool. Soc. Lond. p. 20. Feb. 1833.

\begin{tabular}{rrr} 
Müll. Syn. Test. Viv. p. 180. & 1836. \\
\hline hemicardium Koch. in Phil. Abbild. I. pl. 1. f. 1. & Mar. 1843.
\end{tabular}

\begin{tabular}{llr}
- reversa & Reeve Conch. Icon. pl. 1. f. 5. & Dec. 1843. \\
\hline & Orb. Voy. Amer. Merid. Moll. p. 635. & 1846.
\end{tabular}

Station.-Soft mud, at the depth of 7 fathoms; Cuming ! Sowerby : also Reeve.

Habitat._Tumbez; Cuming! Sowerby : also Reeve: also Orbigny.

Unknown: Koch.

Panama ; C. B. A.!

4 odd valves were found.

\section{Arca similis. Nov. sp.}

Shell ellipsoidal, very inequilateral, slightly aurioulate: inferior margin subrectilinear; anterior and posterior margins well 
rounded: dorsal margin somewhat oblique: white: with an epidermis, which is greenish brown on the young shell, and brownish black on an old shell: with forty to forty-four ribs, which are larger and more sharply angled posteriorly : umbones prominent, flattened, not angulated: area of the ligament narrow, depressed: margins of the interior pectinated by the ribs: teeth small. It resembles $A$. tuberculosa Sowb.

Length 2.2 inches; height 1.3 inch; breadth 1.1 inch.

Station.-Unknown.

Habitat.-Panama; C. B. A.!

10 specimens were obtained.

\section{Arca solida.}

Synonymy.

Byssoarca solida Sowb. in Proc. Zool. Soc. Lond. p. 1E. Feb. 1833.

\begin{tabular}{lrr} 
& - Müll. Syn. Test. Viv. p. 186. & 1836. \\
\hline Arca Reeve Conch. Icon. pl. 16. f. 106. & May 1844. \\
- & - Hanley Descr. Catal. p. 155. & 1845 ? \\
& - Orb. Voy. Amer. Merid. Moll. p. 633. & 1846.
\end{tabular}

Station.--Under stones; Cuming! Sowerby: also Reeve. Our specimens were found under stones, near low water mark.

Habitat.-Payta; Cuming! Sowerby; also Reeve: also Or. bigny.

Peru; Hanley.

Payta; Jay : Lt. Green! Gould MSS.

Panama and Taboga: C. B. A.l

60 speoimens were collected.

\section{Area (Byssoarca) Tabogemsis. Nov. sp.}

Shell not much elongated, not very inequilateral; inferior margin nearly straight, a little gaping for the passage of the byssus; posterior margin oblique, rectilinear or mode- 
rately, excurved; anterior margin well rounded: dingy white, with blackish brown epidermis: with numerous very prominent but very narrow linear ribs, which are often alternately large and small, and of which a few at each extremity are a little stouter and are subnodulous; with a few indistinct concentric lines: umbones prominent, flattened: area of the ligament very narrow, anteriorly widened abruptly: margins of the interior finely and irregularly crenulated: middle teeth very small. The epidermis is between pilose and lamellar, with the points long posteriorly.

Length 1.3 inch; height .85 inch; breadth .65 inch.

Station.-Under stones near low water mark.

Habitat.-Taboga and Panama; C. B. A.I

60 specimens were collected, mostly at Taboga.

\section{Arca tuberculosa.}

Synonymy.

Arca tuberculosa Sowb. in Proc. Zool. Soc. Lond. p. 19.

Feb. 1833.

Múll. Syn. Test. Viv. p. 179.

1836.

Mar. 1843.

- Phil. Abbild. I. pl. 1. f. 2.
- Reeve Conch. Icon. pl. 3. f. 18.
- Hanley Descr. Catal. p. 161.

Jan. 1844. 1845 ?

Station.-Found at low water at the roots of the mangrove trees; Cuming! Sowerby: also Reeve. Our specimens were found in impalpable mud, under a mangrove thicket, near high water mark.

Habitat.-Real Llejos; Cuming I Sowerby : also Reeve, Pacific Ocean, Central America; Philippi.

South America; Hanley.

Real Llejos; Jay.

Mazatlan; Lt, Green! Mus. Essex Inst.

Panama ; C. B. A.I 
We procured 147 specimens, many of which were obtained from the natives. The animal is used by them for food.

\section{Area - Sp. indet. $a$.}

Habitat.-Panama ; C. B. A. 1

2 specimens were found. They are too young for description. The species is remarkable for the prominence and sharpness of one of its two umbonial angles.

\section{Family-CARDIID Æ.}

\section{Cardita affinis.}

\section{Synonymy.}

Cardila affinis Sowb. in Proc. Zool. Soc. Lond. p. 195. Dec. 1832. - Müll. Syn. Test. Viv. p. 211 . May 1836.

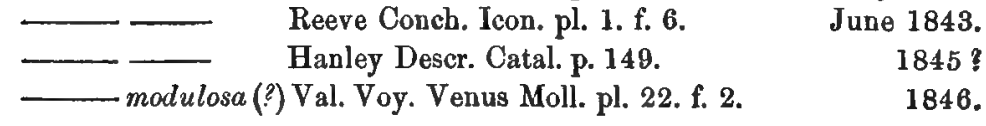

Valenciennes quotes Lamarck for the name which he gives to this species, which must therefore be an error for nodulosa. But the Lamarckian shell probably belongs to a different species, for it is said to be Australian. The name nodulosa is yet farther involved in errors, by its reappearance in Reeve's Iconica for a very different species.

Station.-Sandy mud, at a depth of from 6 to 12 fathoms; Cuming ! Sowerby.

Our specimens were found in stones and rocks at and below half tide level. It is a boring species.

Habitat.-Bay of Montija and Gulf of Nicoya; Cuming! Sowerby : also Müller. Central America; Hanley. Mazatlan; Melchers! Menke.

West Columbia; Jay. 
CARIJTA.

Guaymas; Lt. Green I Gould MSS.

Panama and Taboga; C. B. A.1

70 specimens were collected.

\section{Cardita laticostata.}

Synonymy.

Cardita laticostata Sowb. in Proc. Zool. Soc. Lond. p. 195. Dec. 1832.

\begin{tabular}{llr}
- & Müll. Syn. Test. Viv. p. 210. & May 1836. \\
\hline & Reeve Conch. Icon. pl. 7. f. 36. & Aug. 1843. \\
\hline & Hanley Descr. Catal. p. 146. & $1845 !$ \\
\hline & Orb. Voy. Amer. Merid. Moll. p. 582. & 1846. \\
& Val. Voy. Venus. Moll. pl. 22. f. 1. & 1846. \\
& Reeve Elem. Conch. pl. 35. f. 191. & $1849 !$
\end{tabular}

Station.-In sand, at a depth of 6 to 12 fathoms; Cuming ! Sowerby.

In coarse sand and mud at the depth of from 10 to 12 fathoms; Cuming! Reeve.

Our specimens were found partly buried in calcareous sand and gravel, under stones, near the low water mark of spring tides.

Habitat-Guacomayo, St. Elena, Panama, and Real Llejos; Cuming ! Sowerby : also Müller.

St. Elena, Panama, Real Llejos, Guayaquil, \&c. Cuming ! Reeve.

All the Coast of Peru from Payta to St. Elena in Equador; Orbigny.

Central America; Hanlej.

Guayaquil and Real Llejos; Jay.

Panama; C. B. A.I

We collected 150 specimens on the reef.

\section{Cardita radiata.}

\section{Synonymy.}

Cardita radiata Sowb. in Proc. Zool. Soc. Lond. p. 195. Dec. 1832. JUL.Y, 1852. 
OARDIIDEX.

Cardita radiata Müll. Syn. Test. Viv. p. 211.

May 1836.

- Reeve Conch. Icon. pl. 1. f. 5.

June 1843.

Hanley Descr. Catal. p. 148.

$1845 ?$

1846.

Station.-In muddy sand at the depth of from 6 to 12 fathoms; Cuming! Sowerby: also Reeve.

Our specimens were found near low water mark.

Habitat.-Salango and Panama; Cuming! Sowerby: also Müller : also Orbigny: also Reeve.

West Columbia and Panama;. Hanley.

Salango and Panama; Jay.

Taboga and Panama; C. B. A.l'

We collected 20 specimens in various stages of growth. .

\section{Cardium graniferum.}

\section{Synonymy.}

Cardium graniferum Brod. et Sowb. in Zool. Journ. IV. 367.

1829. Sowb. Conch. Ill. No. 38. pl. 49. f. 1 7. 1841.

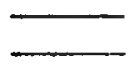
Reeve Conch. Syst. pl. 76. f. I7.

Sept. 1841.

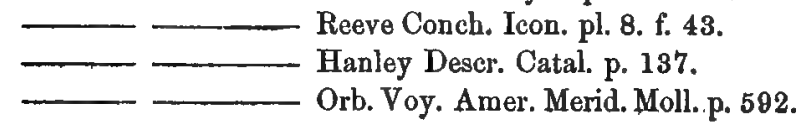

Station.-Unknown.

Habitat.--Mazatlan; Broderip.

Pacific Ocean; Cuming I Sowerby.

- Gulf of Nicoya and Xipixapi; Cuming! Reeve: also Orbigny.

Pacific; Hanley.

West Columbia; Jay.

Panama ; C. B. A. 1

6 odd valves were found. 


\section{Cardium oborale.}

Synonymy.

Cädium obovale Brod. and Sowb. in Proc. Zool: Soc: Lond.

p. 84. - - - - - - July 1833:

\begin{tabular}{rlr}
- & Müll. Syn. Test. Viv. p. 217. & May 1838. \\
\hline & Sowb. Conch. Ill. No. 90. pl. 46. f. 4. & 1841. \\
\hline & Reeve Conch. Syst. pl. 73. f. 4. & Sépt. 1841. \\
\hline & Reeve Conch. Icon. pl. 21. f. 117. & Mar. 1845: \\
\hline & Orb. Voy. Amer. Merid. Moll. p. 503. & 1846.
\end{tabular}

Station.-Sandy mud, at the depth of 11 fathoms; Cuming! Sowerby : also Reeve.

Habitat.-Xipixapi ; Cuming! Sowerby: also Müller: also Reeve : also Orbigny.

Panama; C. B. A.I

3 odd valves of this remarkable species were found.

\section{Cardium planicostatum.}

\section{Synonymy.}

Cardium planicostatum Sowb. Proc. Zool.Soc. Lond. p. 83... July. 1833. - Müll. Syn. Test. Viv. p. 217.. May 1836. f. 25 . 1841.

- Reeve Conch. Icon. pl 6. f. 31. Nov. 1844.

Station.-In fine sand at the depth of 13 fathoms; Cuming !. Sowerby: also Reeve.

Habitat.-Guacomayo; Cuming I. Sowerby : also Müller: also. Reeve. Panama ; C. B. A.!

1 valve of this extremely rare shell was obtained.

\section{Cardium procerum.}

Synonymy.

Cardium procerum Sowb. in Proc. Zool, Soc. Lond. p. 89. July: 1839: 
Cardium procerum Müll. Syn. Test. Viv. p. 216.

May 1836.

1841 .

Sept. 1841.

Reeve Conch. Syst. pl. 77. f. 23.

Dec. 1844. Reeve Conch. Icon. pl. 10. f. 51.

1845 ?

Hanley Descr. Catal. p. 140.

1846 .

Station.-In coarse sand, at a depth of from 4 to 6 fathoms; Cuming! Sowerby: also Reeve.

Habilat.-Real Llejos; Cuming ! Sowerby : also Müller : also Reeve.

Real Llejos; Jay.

Mazatlan; Melchers! Menke.

Panama; C. B. A.!

6 odd valves were collected, and many more were seen on the beach east of Panama.

\section{Cardium senticosum.}

Synonymy.

Cardium senticosum Sowb. in Proc. Zool. Soc. Lond. p. 84. July 1833. Müll. Syn. Test. Viv. p. 218.

May 1836.

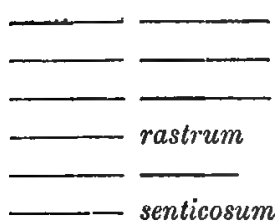

Sowb. Conch. Ill. No. 43. pl. 47. f. 10.

1841.

Reeve Conch. Syst. pl. 74, f. 10.

Reeve in Proc. Zool. Soc. Lond. ubi?

Reeve Conch. Icon. pl. 16. f. $82 . \quad J a n .1845$.

Sept. 1841.

Reeve Conch. Icon. Ind. and Errata of Cardium

Mar. 1845.

Hanley Descr. Catal. p. 137.

$1845 ?$

Orb. Voy. Amer. Merid. Moll. p. 693.

1846.

Mr. Reeve's reference to Proc. Z. S., 1841, for Sowerby's description is evidently a misprint for 1833 ; and the reference to the same work, 1845 , for $C$ rastrum seems erroneous. $\mathrm{Mr}$. Hanley's reference to Reeve Conch. Syst. pl. 84 is also a misprint for 74 .

Siation.-In sandy mud, at from 6 to 12 fathoms depth; Cuming! Sowerby. 
VENUS:

Habitat.-St. Elena; Cuming ! Sowérbÿ : also Müiller : alıö Reeve in Index of Cardium: also Orbigny. S. Ámerica ; Hanley. Taboga; C. B. A.I

5 specimens were found.

$$
\text { Family-VENERID } \text { AE. }
$$

\section{Venus amathusia?}

Synonymy.

Venus amathusia Plıil. Ábbild. I. pl. 2. f. 4.

Apr. 1844.

Station.-Unknown.

Habitat.-Unknown; Philippi.

Mazatlan ; Lt. Green! Gould MSS.

Panama; C. B. A.I

We obtained two specimens.

\section{6: Ventus discodors?}

Synonymy.

Venus discors Sowb. in Proc. Zool. Soc. Lond. p. 42. March 1835, - Orb. Voy: Amer. Merid. Moll. p. 563 . $184 \ddot{8}$.

Station.-In sandy mud at from 6 to 9 fathoms; Cuming ! Sowerby.

Our specimeñs were found in coarse sand among stones between one-quarter and one-half tide level.

Habitat.-St. Elena and Guacomayo; Cumingl Sowerby : also Orbigny.

Guaymas; Lt. Green! Gould MSS.

Panama; C. B. A. 1

We collected 146 specimens on the reef.

\section{3\%" Fenus gnidia.}

Synonymy.

Venus gnidia Brod. et Sowb: in Zool. Journ. IV. 364. JULY, 1852. 
Venus gnidia Gray in Beech. Voy. Zool. pl. 41. f. 3. 1839. - Reeve Conch. Syst. pl. 68. f. 5. Sept. 1841. Hanley's Supp. Wood Ind. Test. pl. 13. f. 43. 1845 ? Hanley Descr. Catal. p. 113. 1845 ? Orb. Voy, Amer. Merid. Moll. p. 564. 1846.

Station.-Unknown.

Habitat.-Pacific; Hanley.

Payta; Fontaine! Orbigny.

San Blas; Jay.

Mazatlan; Lt. Green! Gould MSS.

Panama; C. B. A.!

We obtained 4 specimens of a variety which is distinguished by smaller size and proportionally more approximate concentric ridges. Very fine specimens, with the concentric ridges distant, thin, and much elevated, are sometimes obtained at Panama.

\section{Venus mullicostata.}

\section{Synonymy.}

Venus multicostata Sowb. in Proc. Zool. Soc. Lond. p. $22 . \quad$ Feb 1885.

- Hanloy Descr. Catal. p. 128.

1845 ?

Thouarsi Vul. Voy. Venus. Moll. pl. 16. f. 1.

1840 .

Station.-In coarse sand, at low water; Cumingl Sowerby.

Habitat.-Bay of Panama; Cuming! Sowerby. Panama; Hanley: also Jay.

La Paz; Lt. Green! Gould MSS.

Taboga ; C. B. A.!

5 specimens were collected.

\section{Venus pectunculoides.}

Synonymy.

Venus pectunculoides Val. in Voy. Venus. Moll. pl. 16. f. 3. 1846. 
VEN US.

Station.-In coarse sand, between one quarter and one half tide level.

Habitat.-Guaymas; Lt. Green I Mus. Essex Inst.

$$
\text { Panama; C. B. A.! }
$$

172 specimens were collected under a marine grove, on the reef, \&c.

\section{Venus subrugosa.}

\section{Synonymy.}

Venus subrugosa Sowb. Gen. pl. - . f. 2. pl. - f. 5.

- Reeve Conch. Syst. pl. 67. f. 2.

- Phil. Abbild. I. pl. 3. f. 6, 7.

Cytherea subsulcata Menke must resemble this species.

Station.-We found this mollusk partly buried in coarse sand among stones, or under trees, near half tide level.

Habitat.-Panama; Wood : also Hanley : also Jay. Peru; Philippil Orbigny.

Mazatlan ; Lt. Green ! Gould MSS. : also Mus. Essex Inst.

Pansma; C. B. A. 1

We collected 33 specimens on the reef, and in a marine grove west of Panama.

\section{Venus —. Sp. indet. a.}

12 odd valves were found at Taboga and Panama.

\section{Venus —. Sp. indet. $b$.}

Station.-In coarse sand, near half tide level.

Habitat.-Panama ; C. B. A.!

- We collected 14 specimens. 


\section{Cytherea affinis.}

Synonymy.

Cytherea affinis Sowb. in Proc. Zool. Soc. Lond: p. 45. Mar. 1835. Hanley Supp. Wood Ind. Test. pl. 15. fi $27 . \quad 1845$ ? - Sowb. Thes. Conch. p. 630. No. 62. pl. 132. f.101. 1851.

Station.-Sandy mud at a depth of 10 fathoms; Cuming! Sowerby.

Habitat.-Panama and Xipixapi ; Cuming! Sowerby. Panama; C. B. A. 1

10: specimens were found on the beach west of Panama.

\section{Cytherea aurantiaca.}

Synonymy.

Cytlerea aurantiaca Sowb. Gen. pl. - . f. 3.

$1824 ?$

- Reeve Conch. Syst. pl, 69. f. 3. Sept. 1841.

- aurantia Hanley Supp. Wood Ind. Test. pl. 15. f. 20: 1845$\}$ aurantiaca Jay. Catal. p. 35.

Dec. 1850. aurantia Sowb. Thes. Conch. p. 628. No. 58. pl. 132.

f. 97 bis: - - - - - 1851 .

Station.-Unknown.

Habitat.-Unknown; Sowerby : also Hanley:

Gulf of Nicoya; Jay.

Mazatlan ; Lt. Green! Mus. Essex Inst. : also Gould MSS.

Taboga; C. B. A. 1

We collected 3 specimens of this beautiful shell.

\section{Cytherea consanguinea: Nov." sp:}

Shell obovate, subcordate, with the ventral margin well excurved: very pale straw color, with numerous yellowish brown linear rays, which are more or less interrupted, and which usually terminate before reaching the margin:-smooth and shining, with the lines of growth very minute : beaks pro- 
minent, approximate: posterior area long and narrow, well defined: lunule cordiform, defined by a well impressed line; both areas striate: margin of the interior not crenulate : anterior tooth much larger than the others. This shell belongs to a group of very closely allied species, among which are $C$. inflata, C. albida, C. convexa, \&c.

Length 1.25 inch; height 1 inch; breadth .68 inch.

Station.-Unknown.

Habitat.-Panama ; C. B. A.1

We found 8 specimens on the reef.

\section{Cytherea radiata.}

Synonymy.

Cytherea radiata Sowb. in Proc. Zool. Soc. Lond. p. $23 . \quad$ Feb. 1835. - Hanley in Descr. Catal. p. 108.

Station.-In sandy mud at a depth of 9 fathoms; Cuming! Sowerby.

Habilat._Salango and Xipixapi ; Cuming! Sowerby. West Columbia; Hanley : also Jay.

Panama; C. B. A.!

2 specimens were found.

\section{Cytherea squalida.}

Synonymy.

Cytherea squalida Sowb. in Proc. Zool. Soc. Lond.p. 23. Feb. 1835. biradiala Gray in Beech. Voy. Zool. p. 151. pl. 43. f. 5. 1839. Siebold in Wiegm. Archiv. 1839 . squalida Sowb. Thes. Conch. p. 629. No. 61 (pars). pl. 181. f. 87. (88, 89 exclus.) - - 1851.

Mr. Sowerby (in Thes. Conch.) says that the species, as there constituted, was first named from specimens brought by Mr. JULY, 1852. 
Cuming from the Philippine Islands: but there must be some error in this statement, for in Feb. 1835, Mr. Cuming had not made his collections in the Philippine Islands, and Mr. Sowerby, in the original description in Proc. Zool. Soc. at that time, gave the station and locality as we have quoted below. Consequently the name $C$. biradiata must stand as a synonym of C. squalida, and the shells from the Philippine Islands should be named and desoribed as a distinct species.

Station.-In sandy mud, at a depth of 6 fathoms; Cuming! Sowerby.

Habitat.-St. Elena; Cuming! Sowerby, 1835.

Abundantly at San Blas and Mazatlan; Beechey ! also Siebold.

California ; Sowerby, 1851.

La Paz; Lt. Green! Mus. Eissex Inst.

West Columbia, Mazatlan, and California; Jay. .

Taboga; C. B. A.!

5 specimens were found.

\section{Artemis Dunkeri.}

Synonymy.

Cytherea Dunkeri Phil. Abbild. I. pl. 2. f. 5. Oet. 1844.

Artemis Pacifica (Mus. Berol.) Trosch. in Wiegm. Archiv. p. 324. 1844. - Dunkeri Reeve Conch. Icon. pl. 6. f. 84. March 1850.

Station.-Unknown,

Habitat.-Pacifio shore of Mexico; Philippi : also Troschel. St. Elena and Panama, Central America (?); Cuming! Reeve,

Pacifio; Jay.

Mazatlan; Lt. Green! Gould MSS. : also Mus. Essex Inst.

Panama; C. B. A.!

36 speoimens were found on the beach next west of Panama. 
CYRENA.

\section{Artemis saccata.}

Synonymy.

Athemts saccata Gould in Proc. Bost. Soc. Nat. Hist. p. 91. Not. 1851.

Station.-Unknown.

Habitat.-Mazatlan; Lt. Green I Gould.

Panama; C. B. A.!

2 specimens were obtained:

450. Gouldia Pacifica. Nov, sp.

Shell subtriangular, but with the ventral margin well excurved: the color varying in different specimens from dingy white to pale brown, often tinged with red about the beaks, with some narrow rays of brown, and rarely with short irregu. lar lines of brown : with eight to twelve stout subequal concen. tric ridges: sometimes radiately striated : beaks very acute and closely approximate: posterior area moderately depressed: lunule defined by a well impressed line, rising at the margin of the valves: margin of the interior not.crenulate. It is closely allied to $G$. parva Ad.

Length .22 inch; height .19 inch; breadth .09 inch.

Station.-Unknown.

Habitat.-Panama; C. B. A.!

We collected 4 entire shells and 60 odd valves.

\section{Cyrena maritima. Nov. sp.}

Shell subtriangular, but with the ventral margin well excurved, ventricose, thin: dingy white, more or less violaceous in the posterior half: with an olivaceous coarsely striate epidermis: with well impressed striæ of growth: beaks very prominent, approximate: umbones very prominent: with a prominent posterior angle, and anothẹ less developed posterior 
angle, which defines the area of the corselet: with an indistinct intermediate angle: lunule broad and deep, but not well defined: ligament large: margins thin: with all the cardinal and lateral teeth well developed, but not thick.

The dimensions of two specimens are as follows:-

Length 2 inches; height 1.75 inches; breadth 1.5 inches.

" 2.7 " " 2.25 " 1.95 "

Station.-In impalpable mud, under bushes, at high water mark, where a small stream emptied.

Some of the dead shells, which had not been moved from their station, had Balani growing in them.

Habitat.-Panama; C. B. A.!

$2 \frac{1}{2}$ miles east of Panama 9 specimens were collected.

Family-TELLENID \&.

\section{Lucina tellinoides.}

Synonymy.

Lucina tellinoides Reeve Conch. Icon. pl. 9. f. 56.

June 1850.

Station.-In sandy mud, at a depth of about 11 fathoms; Cuming ! Reeve.

Habitat.-I. of Muerte; Cuming I Reeve.

$$
\text { Taboga; C. B. A.I }
$$

B0 specimens were collected.

\section{Capsa altior.}

Synonymy.

Capsa altior Sowb. in Proc. Zool. Soc. Lond. p. 196.

Dec. 1832.

_ _ Müll. Syn. Test. Viv. p. 225.

May 1836.

Hanley Supp. Wood Ind. Test. pl. 14. f. 34.

$1845 ?$

Hanley Deser. Catal. p. 86.

1845 ?

Station.-Coarse gravel, in 12 fathoms water; and a variety, 
which is smaller and higher, at a depth of 5 fathoms in thin mud; Cuming! Sowerby.

The only living specimen which we found was buried one or two inches deep in sand, on a sandy flat, near low water mark.

Habitat_-Gulf of Nicoya; Cuming I Sowerby : also Müller. Tumbez (for the var. above mentioned); Cuming! Sowerby : also Muiller.

Peru and Central America; Hanley.

Punta St. Elena; Jay.

Panama; C. B. A.l

3 specimens were obtained.

\section{Donax assimilis.}

\section{Synonymy.}

Donax assimilis Hanley in Proc. Zool. Soc. Lond. p. 17. Mar. 1845.

Station.-At about three quarters tide level, buried a few inches deep in sand. It is frequently used for food by the inhabitants. The regard which these mollusks have to a determinate level, was shown by a method for finding them, which was employed by a negro woman, who was seen several times collecting them. Beginning below the level where they might be found, the sand was scooped up with a calabash, in a line running up the beach, until the shells were found. Then by keeping to this level, every calabash full of sand yielded more or less of the Donax.

Habitat.-Panama; Hanley.

Mazatlan; Lt. Green! Mus. Essex Inst.

Panama; C. B. A.!

350 specimens were collected.

\section{Domar gracilis.}

Synonymy.

Donax gracilis Hanley in Proc. Zool. Soc. Lond. p. 15. Feb. 1845. JULY, 1852. 
Station.-Unknown.

Habitat.-Bay of Guayaquil, and of Caraccas, Chiriqui; Cuming! Hanley.

Panama; C. B. A.l

20 odd valves were taken on the beach west of Panama,

\section{Donax navicula.}

Synonymy.

Donax navicula Hanley in Proc. Zool. Soc. Lond. p. 15. Feb. 1845.

Station.-Unknown.

Habitat.-Gulf of Nicoya; Cuming ! Hanley.

Panama; E. Jewett! Gould MSS.

Panama; C. B. A. 1

8 specimens were obtained.

457. Donax rostratus. Nov. sp.

Shell elongated, inequilateral, rostrated anteriorly ; ventral edge excurved along the middle, anteriorly rectilinear; anterior margin very oblique, nearly rectilinear, forming with the ventral edge a rostriform extremity: purple and dingy yellowish brown, more or less in ill defined zones; interior with the same colors not in zones: posteriorly and near the beaks smooth and shin. ing; with rather distant very fine radiating striæ over the middle of the disc; striæ coarser anteriorly, more distant next behind and more crowded before the umbonial angle; the latter are slightly rugose: beaks small, prominent: umbones prominent; with a very sharp angle separating a concave anterior surface ; within slightly radiately striated; with the anterior and ventral margins crenulated, more coarsely and deeply at the anterior extremity: with a prominent lateral tooth on each side of the cardinal teeth. It somewhat resembles $D$. cardinatus Hanley.

Length 1.6 inch; height 1.15 inch; breadth .8 inch. 
Station.-Unknown.

Habitat.-Mazatlan; Lt. Green $\mid$ Gould MSS.

Santa Barbara ; Col. Jewett ! Gould MSS.

Panama; C. B. A.I

1 valve only was obtained.

TELLINA.-The number of species in this genus which occur at Panama is extraordinary : it will be seen that 19 were collected.

\section{Tellina aurora ?}

Synonymy.

Tellina aurora Hanley in Proc. Zool. Soc. Lond. p. 147. Sept. 1844. Hanley in Sowb. Thes. Conch. p. 301. No. 153. pl, 58. f. $76 . \quad-\quad-\quad-1846$.

Station.-Soft sandy' mud in 10 fathoms; Cuming! Hanley.

Habitat.-Panama; Cuming I Hanley.

Rio Janeiro; Jay.

Panama; C. B. A.!

2 entire specimens were found.

Probably there is some error in Dr. Jay's statement. One of our specimens is colorless, and both of them are a little more acuminated posteriorly by the more descending slope of the dorsal margin than the specimen which is figured in the Thesaurus. An odd valve is less acuminated.

\section{Tellina cognata. Nov, sp.}

Shell subelliptical, solid, convex, subequilateral; ventral margin slightly excurved; anterior margin broadly rounded; anterior dorsal margin nearly straight, sloping; posterior dorsal margin slightly concave, sloping equally with the posterior dorsal; posterior extremity somewhat obliquely and very broadly truncated; flexure slight; white, with a pale reddish or brownish tinge; with excessively minute unequal radiating 
striæ; with concentric crowded somewhat oblique minute striæ, which terminate much before reaching the umbonial angle, covering less than half of the posterior side, and which are also wanting near the anterior dorsal margin: beaks not very prominent: ligament short, conspicuous: lateral teeth obsolete. It is closely allied to T. similis, which is said to be a Caribbean species.

Length 1.75 inch; height 1.23 inch; breadth .5 inch.

Slation.-Unknown.

Habitat.-Panama; C. B. A.I

A single valve was found.

\section{Tellima Columbiensis.}

\section{Synonymy.}

Tellina Columbiensis Hanley in Proc. Zool. Soc. Lond. p.71. - - Apr. 1844。 Hanley in Sowb. Thes. Conch, p. 307. No. 166. pl. 65. f. 246 . - - 1846.

Station.-Sandy mud, 12 fathoms; Cuming! Hanley.

Fabitat,-Monte Christi; Cuming I Hanley. l'aboga; C. B. A.I

2 specimens were found.

\section{Tellina concinna. Yov. sp.}

Shell subelliptical, rather thin, convex, with the anterior side a little larger; ventral margin moderately excurved; anterior margin broadly rounded; anterior dorsal margin a little excurved, moderately sloping; posterior dorsal margin nearly straight, sloping equally with the anterior dorsal margin; posterior extremity somewhat obliquely and very broadly truncated; flexure slight: shining, snow-white, with a slight tinge of pink in the middle; with very unequal, and, for the most 
part, very fine concentric striæ, which are much coarser posteriorly; with excessively minute unequal radiating striæ: beaks not very prominent: ligament short, conspicuous: lateral teeth obsolete.

Length 1.6 inch; height 1.02 inch; breadth .47 inch.

Station.-Unknown.

Habitat.-Panama; C. B. A.1

3 fine specimens were obtained.

\section{Tellina crystallina:}

Synonymy.

Tellina crystallina (Chem. XI. 210. f. 1947-8; teste Hanley) (Wood.Ind. Tést. pl. 3. f. 10 ; teste Hanley)* Wood. Gen. Conch. p. 149.

1835.

Hanley Descr. Catal. p. 66.

Hanley in Sowb. Thes. Conch. I. 270. pl. 57. f. 43 .

1846.

Station.-Unknown.

Habitat.-St. Elena; Hanley.

Panama ; C. B. A. 1

We obtained only 1 valve.

\section{Tellina Cumingii.}

Synonymy.

Tellina Cumingii Hanley in Proc Zool. Soc. Lond. p. 59. Apr. 1844. Hanley in Sowb. Thes. Conch. p. 223.

No. 3. pl. 58: f. 72. - - - - 1846.

Station.-In coral sand; Cuming! Hanley.

Habitat_-Guacomayo; Cumingl Hanley.

Panama; C. B. A.I

We found only 1 entire shell and 1 single valve.

* We have not had an opportunity of coneulting Chernnitz' and Wood's Index since this species was deternined.

JULT, 1852.

Axr. Lyc. NAt. Hest. 


\section{Tellima Dombei.}

\section{Synonymy.}

Tellina Dombei Hanley in Proc. Zool. Soc. Lond. p. 144. Aug. 1844. Hanley in Sowb. Thes. Conch. p. 323.

No. 199. pl. 62. f. 182 . - - - 1846.

Station.-In sandy mud, 12 fathoms; Cuming! Hanley.

Habitat.-Panama; Cuming! Hanley.

Panama; Jay.

Panama; C. B. A.! .

12 specimens were collected.

\section{Tellina felix.}

Synonymy.

Tellina felix Hanley in Proc. Zool. Soc. Lond. p. 71.

Apr. 1844.

Hanley in Thes. Conch. p. 281. No. 110. pl. 57.

fig. 52.

1846 .

Station.-Sandy mud, 6 to 10 fathoms; Cuming! Hanley.

Habitat.-Panama; Cuming! Hanley.

Panama; C. B. A.!

We collected 36 odd valves on the beach west of Panama.

\section{Tellina laceridens.}

Synonymy.

Tellina laceridens Hanley in Proc. Zool. Soc. Lond. p. 61. Apr. 1844. Hanley in Thes. Conch. p. 243. No. 40. pl. 61.f. 168.176. - - - $\quad$ - $\quad$ - 1846.

Station.-Sandy mud, 3 to 5 fathoms; Cuming ! Hanley.

Habitat.-Tumbez and Chiriqui ; Cuming! Hanley. West Columbia; Jay. 
TELLINA.

Panama; C. B. A. 1

7 specimens were collected on the sand beaches.

\section{Tellina prora.}

Synonymy.

Tellina prora Hanley in Proc. Zool. Soc. Lond. p. 61.

Apr. 1844.

Hanley in Sowb. Thes. Conch. p. 243. No. 39.

pl. 60. f. $152 . \quad-\quad-\quad-\quad-1846$.

Station.-Sandy mud, 6 to 9 fathoms; Cuming! Hanley.

Habitat.-St. Elena and Salango; Cuming I Hanley.

Salango ; Jay.

Panama ; C. B. A.!

A single valve was found.

\section{Tellina puella. Nov, sp.}

Shell elongate, rather solid, convex, moderately inequilateral; ventral margin slightly excurved, posteriorly straight; anterior margin broadly rounded; anterior dorsal margin slightly excurved; posterior dorsal margin straight, rapidly sloping to an acute posterior extremity; flexure moderate: white, more or less deeply tinged with red, mostly near the margin : shining; with excessively minute concentric striæ, and some faint micro. scopic radiating strix: beaks not very prominent: ligament small: lateral teeth well developed.

Length .9 inch; height .53 inch; breadth .28 inch.

Station.-Unknown.

Habitat.-Panama; C. B. A.!

12 odd valves were collected.

\section{Tellima rubescens.}

Synonymy.

Tellina rubescens Hanley in Proc. Zool. Soc. Lond. p. 60. Apr. 1844. 
Tellina rubescens Hanley in Sowb. Thes. Conch. p. 242. No.

38. pl. 60. f. 153.

1846.

Station.-In sandy mud; Cuming! Hanley.

Habitat.-Panama and Tumbez; Cuming! Hanley.

Tumbez; Jay.

Panama; C. B. A.!

2 specimens were found.

\section{Tellina siliqua. Nov. sp.}

Shell elongate, subelliptic, very thin, very convex, very inequilateral; ventral margin nearly straight; anterior margin well rounded; anterior dorsal margin slightly excurved, moderately sloping; posterior dorsal margin straight or concave, sloping to a small subtruncate posterior extremity; Hexure great: pure white: with excessively minute concentric striæ: beaks acute: ligament small : cardinal teeth small ; lateral teeth wanting. Dr. Gould suggested the very appropriate name which we have adopted.

Length .7 inch; height .4 inch; breadth .3 inch.

Station.-Unknown.

Habitat.-Panama; C. B. A.!

1 specimen was found.

\section{1.-Tellina simulan's. Nov, sp.}

Synonymy.

Tellina punicea (pars) Hanley in Sowb. Thes. Conch. I. $239 . \quad 1846$.

Shell subovate, solid, moderately convex, nearly inequilateral; ventral margin slightly excurved; anterior margin well rounded; anterior dorsal margin slightly excurved; posterior dorsal margin nearly straight, sloping; posterior extremity obliquely truncated; flexure slight: white, more or less deeply tinged with rose color except near the margin and around the 
pure white beaks; within of a very deep red: shining; with deep crowded regular concentric sulci, which are of equal depth at both extremities: beaks prominent: ligament short, conspicuous: with a long posterior dorsal area well defined by an angle: lateral teeth nearly obsolete. The difference between this shell and T.punicea is slight: its furrows are deeper and are continued over the flexure without change of depth; the interspaces are less flattened, and the lateral teeth are nearly obsolete.

Length 1.13 inch; height .7 inch; breadth .3 inch.

Station.-In sandy mud at 10 fathoms: Cuming! Hanley.

Habitat.-Xipixapi; Cuming $!$ Hanley. Panama; C. B. A.I

1 valve was found.

\section{Tellina sincera.}

\section{Synonymy.}

Tellina sincera Hanley in Proc. Zool. Soc. Lond. p. 68. Apr. 1844. Hanley in Thes. Conch. p. 261. No. 70.

$$
\text { pl. 60. f. 144. - - - - } 1846 .
$$

Station.-Unknown.

Habitat. -N. W. Coast of America (Dr. Sinclair); Hanley in Thesaurus.

Panama; C. B. A. 1

15 specimens were obtained on the beach west of the town.

\section{Tellina vicina. Nov. sp.}

Shell very short, subovate, solid, convex, subequilateral; ventral margin well excurved, sometimes slightly incurved near the flexure; anterior margin broadly rounded; anterior and posterior dorsal margins nearly straight; sloping; posterior extremity subtruncated; flexure moderate: dingy white, sometimes tinged with yellowish brown; sometimes deep red, with 
a tinge of blue or grey; some whitish specimens are ornamented with bluish purple zigzag lines on the umbones, or with a short ray of the same color before the beaks: with deep unequal crowded concentric striæ: beaks prominent: ligament short, conspicuous: lateral teeth rather small. This species is closely allied to T. bimaculata, and has similar varieties of coloring, but is larger, higher, and has coarser striæ.

Length .95 inch; height $.78 \mathrm{inch}$; breadth .4 inch.

Station.-Unknown.

Habitat.-Panama; C. B. A.!

10 specimens were collected.

\section{Tellima - Sp. indet. $a$.}

1 valve, obtained near Panama, resembles an overgrown T. elongata Hanley, which species Mr. Cuming found at Chiriqui : but the figure of that species in Sowb. Thes. represents the umbonial angles as concave upwards, but in this shell they are convex upwards, and consequently the posterior area is less. Our specimen is more than 3 incbes long.

\section{Tellima - Sp. indet. $b$.}

A long elliptic plain white shell; 1 valve was found near Panama.

476. Tellima - Sp. indet. c.

Like T. puella, but less rostrate and more deeply striate; $\mathbf{5}$ odd valves were found near Panama.

Family-PETRICOLID

477. Petricola cognata. . Nov. sp.

Shell pholas-shaped, inequilateral: dingy white: in the upper posterior area with very fine crowded radiating equal 
striæ; in the lower posterior area with unequal fine raised radiating lines; in the anterior half with radiating ribs, which are ornamented with small thick vaulted scales; beaks small, prominent: umbones prominent, somewhat flattened: lunule defined by the anterior ribs, a little depressed: ventral margin scalloped anteriorly. It is allied to $P$. pholadiformis Lam.

Length .92 inch; height .42 inch; breadth .44 inch.

Station.-Unknown.

Habitat.-Panama; C. B. A.!

1 specimen was obtained.

\section{8.: Saxicava tenuis?}

Synonymy.

Saxicava tenuis (?) Sowb. in Proc. Zool. Soc. Lond. p. 88. Aug, 1834.

The description of this species is too meagre to enable us to identify our shell confidently.

Station.-In soft stones near half tide, level.

Habitat -Pacosmayo and Lambeyeque; Cuming 1. Sowerby. Panama; C. B. A. 1

1 specimen. was found in the same stone with Modiola, sp. indet. $e_{\text {. }}$

Famíly-MACTRID无.

479. Cumingia coarctata.

Synonymy.

Cumingia coarctata Sowb. Gen. pl. - . f. 4.

Sowb: in Proc. Zool. Soc. Lond. p. 34. Mar. '1833.

Reeve Conch. Syst. pl. 49. f. 4.

Sept. 1841.

Hanley Supp. Wood Ind. Test. pl. 12. f. 37. 1845?

Station.-Sandy, muddy :bottom, 7 fathoms water; Cuming! Sowerby. 
Habitat.-Bay of Caraccas; Cuming! Sowerby. Panama; C. B. A.!

4 specimens were obtained.

\section{Cumingia trigonularis.}

Synonymy.

Cumingia trigonularis Sowb. in Proc. Zool. Soc. Lond. p. 35. Mar. 1833. Sowb. Gen. pl. -. f. 2.

Reeve Conch. Syst. pl. 49. f. 2. Sept. 1841.

Station.-Among stones in deep water; Cuming! Sowerby.

Habitat.-St. Elena: Cuming! Sowerby.

Panama; C. B. A. 1

3 specimens were found.

481. Cumingia - Sp. indet. $a$.

4 specimens were obtained near Panama.

482. Cumingia - Sp. indet. $b$.

1 specimen was obtained near Panama.

483. Cumingia - Sp, indet. $c$.

1 valve was found near Panama.

484. Cumingia - Sp. indet. $d$.

1 specimen was found near Panama.

The above are probably new species of Cumingia; but as their characters are probably somewhat variable, more specimens are requisite for good descriptions.

\section{Amphidesma bicolor. Nov, sp.}

Shell elliptical, scarcely flexuous, inequilateral, the posterior side being larger; with the posterior dorsal margin a little con- 
cave, otherwise with all the margins well rounded : purple near the beaks, otherwise dingy white: interior similarly colored, but with the purple region larger: smooth near the beaks, otherwise with fine raised concentric lines, and crowded radiating stria, which are mostly microscopic, and which posteriorly are divergent and wholly microscopic; beaks small, prominent: umbones convex.

Length .85 inch; height .74 inch; breadth .42 inch.

Station.-Unknown.

Habilat_Panama; C. B. A.I

Only 1 valve was found.

\section{Amphidesma ellipticum ?}

Synonymy.

Amphidesma ellipticum Sowb. in Proc. Zool. Soc. Lond. p. 200. - Dec. 1832 Hanley Descr. Catal. p. 45. 1845 ?

Slation.-Dredged at a depth of 9 fathoms in sandy mud; Cuming ! Sowerby.

Habitat.-Monte Christi; Cuming ! Sowerby. West Columbia; Hanley.

Panama; C. B. A. 1

We obtained 20 specimens on the reef at low water mark. Most of them are in fine condition, although none were taken alive.

\section{Amphidesma proximum. Nov. sp.}

Shell suborbicular, slightly flexuous, a little inequilateral, with the anterior dorsal margin concave, with the posterior dorsal margin a little excurved, subtruncated posteriorly, otherwise with the margins well rounded: snow white, with a thin slate or umber-colored epidermis : centrally and anteriorly with very fine rather distant raised lines; with extremely minute 
radiating striø over the whole surface: beak small, approximate: left umbo more convex than the right one : corselet and lunule long and narrow, concave. It is closely allied by varieties to $A$. ellipticum Sowb. : it corresponds mostly to the descriptions of $A$. lenticulare Sowb., but the figures of that species in Sowb. Conch. Ill. and Hanley App. Wood Ind. appear to represent a distinct species.

Sometimes the shell is tinged with brownish orange near the beaks and middle portion, espeoially in the interior. In some specimens the inner surface within the pallial line is finely and deeply punotated, and the deep pallial sinus is marked with strio radiating from the opening of the sinus.

Lèngth $1.8 \mathrm{inch}$; height $1.58 \mathrm{inch}$; breadth $.82 \mathrm{inch}$.

Station.-Unknown.

Habitat._Panama; C. B. A.!

18 specimens were taken on the reef at low water mark.

\section{Amphidesma pulchrum.}

\section{Synonymy.}

Amphidesma pulch'um Sowb. in Proc. Zool. Soc. Lond. p. 57. Mar. 1832. \begin{tabular}{rr}
- Mull. Syn. Test. Viv. p. 221. & May 1836. \\
\hline- Sowb. Conch. Ill. No. 2. pl. 17. f. 2. & 1841. \\
\hline Reeve Conch. Syst. pl. 47. f. 2. & Sept. 1841. \\
\hline Hanley Supp. Wood Ind. Test. pl. 12. f. 6. $1845 ?$ \\
\hline Hanley Descr. Catal. p. 45. & 1845 ? \\
\hline Orb. Voy. Amer. Merid. Moll. p. 594. & 1846.
\end{tabular}

Station.-Unknown.

Hlulilat.-Bay of Caraccas; Cuming! Sowerby in Proo. Zool. Soo. : also Müller.

Bay of Caraccas; Orbigny.

St. Elena and Panama; Cuming! Sowerby in Conch. Ill.

S. America; Hanley. 
St. Elena ; Jay.

Panama; C. B. A. 1

We found 4 specimens.

\section{Amphidesma striosum. Nov. sp.}

Shell elliptical, slightly flexuous, inequilateral; with the posterior dorsal margin slightly excurved, with the anterior dorsal margin concave, otherwise with the margins well rounded: pale yellowish brown : with numerous fine raised concentric lines, and closely crowded radiating striæ, which are mostly microscopic: beaks small, approximate : umbones convex : corselet and lunule not well defined.

Length .78 inch; height .71 inch; breadth .33 inch.

Station.-Unknown.

Habitat.-Panama; C. B. A.l

1 specimen was found.

\section{Amphidesma tortuosum. Nov. sp.}

Shell compressed, subequilateral, triangular above, orbicular below, the slightly excurved posterior dorsal margin and the slightly concave anterior dorsal margin meeting at an angle of about $125^{\circ}$, and the rest of the margins being well rounded; posterior side very flexuous, with a broad deep groove on the left valve and a corresponding ridge on the right valve: dingy white: with numerous concentric ridges, which are crossed by radiating strize that are partly microscopic: beaks very minute, approximate: left umbo flat, right one convex: corselet and lunule long and narrow, deeply concave.

Length 1.25 inch; height 1.1 inch; breadth .35 inch.

Station.-Unknown.

Habitat.-Panama ; C. B. A.1

1 specimen was obtained. 
491. Amphidesma ventricosum. Nov. sp.

Shell suborbicular, subequilateral, ventricose, flexuous; with the anterior and posterior dorsal margins nearly straight; with the margins otherwise well rounded : dingy white, brownish in ill-defined zones: with unequal stric of growth; densely covered with radiating microscopic stria : beaks small, approximate: umbones very convex: corselet and lunule not very well defined.

Length .7 inch; height .62 inch; breadth .36 inch.

Station.-Unknown.

Habitat.-Panama; C. B. A.!

A single valve only was found.

\section{Crassatella gibbosa.}

Synonymy.

Crassatella gibbosa Sowb. in Proc. Zool. Soc. Lond. p. 56. Mar. 1832.

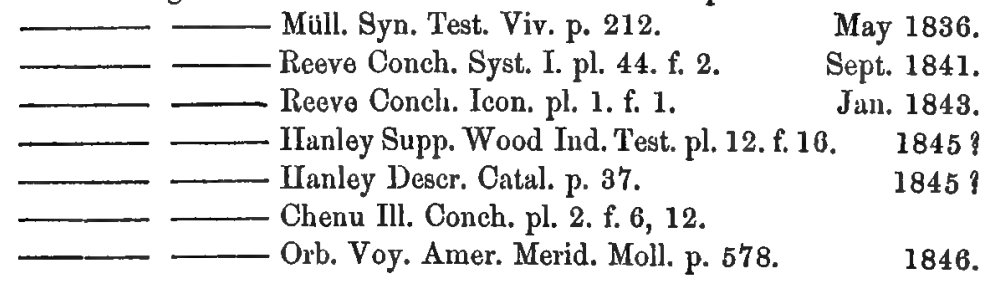

Station.-Sandy mud, 11 fathoms ; Cuming! Sowerby : also Reeve.

Habitat.-St. Elena and Xipixapi; Cuming ! Sowerby : also Müller: also Orbigny : also Reeve.

Payta; Fontaine! Orbigny.

S. America; Hanley.

Punta St. Elena; Jay.

Panama; C. B. A !

Only 1 valve was obtained. 
LUTRÄLÁ.

Panama Shells.

293

\section{3.' Mulinia donaciformis.}

Synonymy.

Mulinia donacïformis Hanley Descr. Catal.' p. 35.

1845 !

- Hanley Supp.Wood. Ind. Test. pl. 10. f. 29. 1845?

This species, according to Hanley, was described by Gray in Mag. Nat. Hist. 1837, and figured in Zool. Beech. Voy. pl. 44. f. 13,1839 ; but not having these books before us since our specimens were determined, we have not verified these references.

Station.-Unknown.

Habitat.-South Seās; Hanley.

Panama; Col. Jewett ! Gould MSS.

Panama; C. B. A. I

14 specimens were collected on the beach west of Panama.

\section{Muilinia ventricosa.}

Synonymy.

Lutraria ventricosa Gould Proc. Bost. Soc. Nat. Hist. IV.88. Nov. 1851.

Slation.-Unknown.

Habitat.-Mazatlan; Lt. Green I'Gould.

Panama; C. B. A.I

3 specimens were collected on the beich west of Panama.

\section{Lutrairia elegams. ,}

Synonymy.

Mactra elegans Sowb. in Tank. Catal. No.116.App.p. 2.pl.1.f.3. 1825. Desh. in Lam. An. sans Vert. VI. 107. Hanley Descr. Catal. p. 33. $1845 ;$

Hanley Supp. Wood. Ind. Test. pl. 11. f. 16. 1846?

Station.-Unknown.

Habitat.-Unknown; Sowerby : also Deshayes. JULY, 1852. 
Florida; Hanley.

Panama; C. B. A.!

We collected 6 odd valves of this rare and elegant shell. $L$. canaliculata Say is the Atlantic analogue. Dr. Gould has shown us his $L$. undulata, which is quite distinct from either species. Mr. Hanley must be in error as to the habitat of the species. Its Atlantic analogue inhabits Florida, but is not likely to have been confounded with this shell.

\section{Mactra velata.}

\section{Synonymy.}

Mactra velata Phil in Zeitschr. Mal.p. 153. No. 10 for 1848. Mar. 1849. - Phil. Abbild. III. pl. 3. f. 5.

Nov. 1850.

This shell attains a length of 4 inches. A small variety $(a)$ has the posterior dorsal outline much less excurved. It may possibly be a distinct species. Col. Jewett's specimens belong to this type.

Station.-Unknown.

Habitat.-Panama; E. B. Philippi I Philippi.

Panama; Troschel.

Panama; Col. Jewett! Gould MSS.

Panama; C. B. A.!

10 specimens were found on the reef.

\section{Family-CORBULID 压.}

\section{Amatina alta. Nov. sp.}

Shell ovate, short; anteriorly subangular and flexuous; atherwise with the margins well rounded: pearl-white, with a thin brownish epidermis: with unequal striø of growth; surface microscopically sagrinate: beaks small, prominent, approximate : umbones moderately convex: spoon-shaped tooth followed by a well rounded deep sinus under the beak. 
Length 1.98 inch; height 1.35 inch; breadth .7 inch.

Station.-Unknown.

Habilat.-Panama ; C. B. A.!

1 valve only was found.

\section{Pandora cornuta. Nov. sp.}

Shell elongate, ovate, very inequilateral, the posterior part being much longer and higher; dorsal margin nearly straight, posteriorly sharply rostriform; posterior margin much excavated next beneath the rostriform projection; ventral margin well rounded : pearl-white: with some unequal striæ of growth; right valve with a prominent angle extending from the beak to the middle of the sinus of the posterior margin ; left valve with a corresponding depressed angle: beaks indistinct: umbones slightly and almost equally convex.

Length .7 inch; height .42 inch; breadth .11 inch.

We adopt the appropriate name suggested by Dr. Gould.

Station.-Unknown.

Habitat.-Panama; C. B. A.!

Only 1 specimen was found.

499. Potamomya aequalis. Nov. sp. Thefing cequ

Shell subovate, nearly equilateral, slightly inequivalve; with the margin subangulated posteriorly, otherwise well rounded: white beneath a pale brown epidermis: with unequal strim of growth; posteriorly with an umbonial angle not very prominent: beaks small: right umbo very prominent, both somewhat compressed: tooth rather small; teeth of the left valve with a medial ridge.

Length $.78 \mathrm{inch}$; height .66 inch; breadth .42 inch.

Station.-In soft impalpable mud, under a mangrove thicket, near bigh water mark, and near the outlet of a small stream, with Arca tuberculosa. 
Habitat.-Panama ; C. B. A.!

1 specimen was obtained about $2 \frac{1}{2}$ miles east of Panama.

500. Polamomya inflata. Nov. sp.

Shell ovate, ventricose, inequilateral, moderately inequivalve; posterior margin subtruncated between the extremities of two umbonial angles, of which the upper one is indistinct; ventral margin moderately excurved; anterior margin abruptly and regularly rounded: white beneath a pale brown epidernis: with unequal strim of growth: beaks small: umbones very prominent, somewhat compressed: teeth small; tooth of the left valve with a medial ridge.

Length .7 inch; height .67 inch; breadth .5 inch.

A less ventricose variety has the following dimensions:

Length $: 6$ inch; height .46 inch; breadth .33 inch.

Station.-With $P$. cequalis, q. v.

Habitat.-Panama; C. B. A.!

3 specimens were obtained with $P$. cequalis.

\section{Potamomya trigonalís. Nov. sp.}

Shell solid, triangular, moderately inequivalve, subequilateral; upper posterior margin moderately excurved, forming an angle with theislightly excurved ventral margin; anteriorly with the dorsal margin abruptly :and regularly rounded into the ventral margin: white beneath a pale brown epidermis: with fine striæe of growth; with a sharp umbonial angle defining a posterior area: bealss large and prominent: umbones prominent, somewhat compressed: teeth large and robust; tooth of the left valve with a medial ridge.

Length .95 inch; height .8.inch; breadth .56 inch.

Station.-With $P$. arqualis, q. v.

Habitat.-Panama ; C. B. A.I

2 specimens were obtained. 
CORBUULA.

\section{Corbula bicarimata.}

Synonymy.

Corbula bicarinata Sowb. in Proc. Zool. Soc. Lond. p. 35. Mat. 1833.

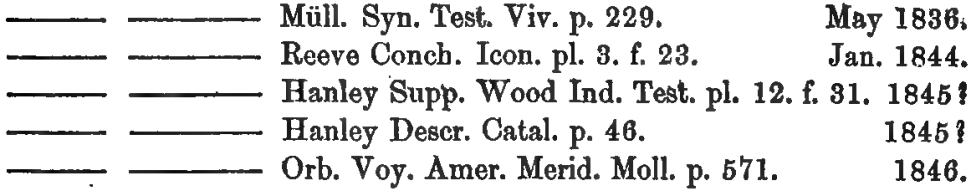

Station.-In sandy mud, at the depth of from 7 to 17 fathoms; Cuming I Sowerby: also Reeve.

Our specimens were found under stones, whioh were sunk deep in sand, a little above low water mark.

Habitat.-Panama, Real Ilejos, Caraccas, St. Elena, \&c.; Cuming I Sowerby : also Milller: also Orbigny: also Reeve.

West Columbia; Hanley; also Jay.

Panama ; C. B. A.!

260 specimens were collected on the reef.

\section{Corbula biradiata.}

Synonymy.

Corbula biradiata Sowb. in Proc. Zool. Soc. Lond. p. 35. Mar. 1833.

\begin{tabular}{l}
- Müll. Syn. Test. Viv. p. 230. \\
\hline Reeve Conch. Icon. pl. 1. f. 3. May 1836.
\end{tabular}

\begin{tabular}{l}
- Müll. Syn. Test. Viv. p. 230. \\
\hline Reeve Conch. Icon. pl. 1. f. 3.
\end{tabular}

- Hanley Supp. Wood Ind. Test. pl. 10. f. 51. 1845 ?

—_ Hanley Descr. Catal. p. 47. 1845?

Orb. Voy. Amer. Merid. Moll. p. 571. 1846.

Station.-In sand and mud, at the depth of from 3 to 7 fathoms; Cuming! Sowerby; also Reeve.

Habitat.-Chiriqui and Bay of Caraccas; Cuming I Sowerby: also Müller: also Orbigny : also Reeve.

Caraccas; Hanley.

JULY, 1852 
West Columbia; Jay.

Panama; C. B. A. 1

1 entire specimen and 8 odd valves appear to be the shell described as above. 2 entire specimens and 10 odd valves of a beautiful variety were also obtained.

\section{Corbula obesa.}

Synonymy.

Corbula obesa Hinds in Proc. Zool. Soc. Lond. p. 57. May 1843. Reeve Conch. Icon. pl. 5. f. 38.

May 1844.

- Hinds Zool. Voy. Sulph. Moll. p. 68. pl. 20. f. 12. 1844.

Station.-Mud, at the depth of 22 to 33 fathoms; Hinds! also Reeve.

Habitat.-West coast of America, between $8^{\circ} 57^{\prime}$ and $21^{\circ} 32^{\prime}$ N. lat., Panama, Veragua, San Blas, \&c. ; Hinds! also Reeve.

San Blas; Jay.

Panama; C. B. A. 1

6 odd valves were found.

\section{Corbula ovulata.}

Synonymy.

Corbula ovulata Sowb. in Proc. Zool. Soc. Lond. p. 35. Mar. 1833.

- Müll. Syn. Test. Viv. p. 230.

- - Reeve Conch. Icon. pl. 1. f. 7 . May 1836. Hanley Deser. Catal. p. 47. Aug. 1843.

- Hanley Supp. Wood Ind. Test. pl. 10.‡. 52. 1845 ? Orb. Voy. Amer. Merid. Moll. p. 571.

1846.

Station.-In sandy mud, at various depths from 7 to 17 fathoms; Cuming! Sowcrby : also Reeve.

Habitat.-Xipixapi and Bays of Montijo and Caraccas: Cuming I Sowerby : also Muiller: also Orbigny: also Reeve.

On the sands at Real Llejos and Mazatlan, a few 
odd valves, of a clear pink color, were picked up; Cuming ! Sowerby: also Reeve.

S. America; Hanley.

Taboga; C. B. A. I

6 odd valves and 1 entire specimen were found. The latter is of extraordinary size and thickness. Its dimensions arelength 1.22 inch; height .81 inch; width $.68 \mathrm{inch}$ : it weighs $\frac{3}{6}$ oz. On and around the umbones, it is of a clear pink color.

506. Corbula rubra. Nov. sp.

Shell subovate, moderately inequivalve and inequilateral, posteriorly acuminate, with the ventral margin arcuate, anteriorly rounded : rufous, with a short white ray on the anterior side of the umbo, and a dark red spot before it: with fine concentric striæ, decussated by radiating microscopic striæ: beaks not very prominent: umbones prominent, somewhat angulated on both sides near the beaks: teeth small. Our unique specimen has a broad flexure a little behind the middle: but this may be an accidental growth.

Length .31 inch; height.19 inch; breadth .14 inch.

Station.-Unknown.

Habitat.-Panama ; C. B. A. 1

Only 1 specimen was obtained.

507. Corbula tenuis. Nov. sp.

Synonymy.

Corbula tenuis Sowb. in Proc. Zool. Soc. Lond. p. $36 . \quad$ Mar. 1836. Müll. Syn. Test. Viv. p. 231.

Reeve Conch. Icon. pl. 2. f. 13.

Sept. 1843.

Station.-Sandy mud, at the depth of 12 fathoms; Cuming! Sowerby : also Reeve.

Babitat.-Bay of Montijo; Cuming! Sowerby : also Muiller : also Reeve.

Mazatlan; E. Jewett! Gould MSS.

Panama; C. B. A.I 
Of this species, hitherto unique in the Cumingian collection, we obtained only 1 specimen of the convex valve. Col. Jewett also brought a convex valve to Dr. Gould, and retained another odd valve from Mazatlan.

508. Corbula - Sp. indet. $a$.

This species has some resemblance to $C$. Taheitensis. Wo obtained at Panama but 1 valve, which is probably immature.

\section{Corbula - Sp. indet. $b$.}

Two left valves were obtained at Panama.

Family-SOLENID AE.

\section{Solecurtus affimis. Nov. sp.}

Shell much elongated, compressed cylindric, well rounded at both extremities; ventral edge straight or slightly arcuated: white beneath a deep yellowish brown epidermis: with unequal striø of growth : beaks not prominent, a little behind the middle of the shell: umbones compressed along the middle: ligament broad, with stout nymphæal callosities: teeth small, one in the left, and two in the right valve. This is the analogue of S. Camboeus.

Length 2.25 inches; height .8 inch; breadth .55 inch.

Station.-Unknown.

Habitat.-Panama; C. B. A. 1

10 specimens were collected.

511. Solem rudis. Nov. sp.

Shell solid, straight or slightly recurved; with the posterior extremity abruptly truncated nearly perpendicularly; anteriorly with very thick rounded margins: white beneath a brown deciduous epidermis, which is produced much beyond the margins : with only indistinct strix of growth on the shell; with some radiating lines on the epidermis : beaks inconspicu- 
ous, at one seventh of the length from the anterior extremity: ligament large, with stout nymphral callosities: teeth large in. old shells.

Length 5.8 inches; height 1.3 inch; breadth 1 inch.

Station.-In coarse sand, among stones, near low water mark.

\section{Habitat.-Panama; C. B. A. 1}

55 specimens were collected on the reef. It is an edible species, and many of our specimens were obtained from the natives, who were digging them for food.

\section{Family-PHOLADIDAE.}

\section{Pholas crucigern.}

Synonymy.

Pholas crucigera Sowb. in Proc. Zool. Soc. Lond. p. 69. July 1834. - cruciger Müll. Synop. Nov. Test. Viv. p. 236. May 1836. — Orb. Voy. Amer. Merid. Moll. p. 499. — crucigera Hanley Supp. Wood Ind. Test. pl. 11.

f. $53 . \quad-\quad-\quad-\quad-\quad-1845$ ?

- Hanley Descr. Catal. p. 6. 1845 ?

- Sowb. Thes. Conch. Index. 1849. crucifera Sowb. Thes. Conch. p. 489. No. 13. pl.

104. f. 24-6. - - - - - 1840. crucigera Phil. Abbild. III. pl. II. f. 4. - - - Nov. 1850.

Station.-In soft sandstone at half tide; in soft stone at low water; in hard clay at the depth of 13 fathoms; Cuming I Sowerby.

Habilat.-I. of Puna, Bay of Caraccas, and Gulf of Nicoya; Cuming! Sowerby : also Muiller.

Central America; Hanley: also Orbigny: also Jay.

Panama; C. B. A.!

1 specimen was found. BULT, 1852. 


\section{Pholas tubifera.}

Synonymy.

Pholas tubifera Sowb. in Proc. Zool. Soc. Lond. p. 71.

July 1834. Mull. Synop. Nov. Test. Viv. p. 238.'

May 1836. Orb. Voy. Amer. Merid. Moll. p. 499.

1843. Hanley Descr. Catal. p. 8.

$1845 ?$ Sowb. Thes. Conch. p. 499. No. 41. pl. 106. f. 64, 65 .

1849.

Station.-In decayed wood, dredged up at 10 fathoms' depth; Cuming I Sowerby.

Habitat.-Bay of Caraccas; Cuming! Sowerby: also Müller. Payta; Fontaine! Orbigny.

West Columbia; Hanley: also Jay.

Panama; C. B. A.!

1 specimen was found.

514. Pholas xylophaga. ( $\nabla$ al. non Desh, et al.)

Synonymy.

Penitella xylophaga (?) Val. Voy. Venus Moll. pl. 24. f. 2: 1846.

Station.-Boring in wood, near high water mark.

Habitat.-Panama; C. B. A.!

20 specimens were taken from the bottom of an old "dug. out," on the rocks near the sea wall. The bottom of the canoe was filled with this mollusk.

\section{Pholas —. Sp. indet. $a$.}

2 right valves were found near Panama. It resembles $P$. lanceolata Orb.

516. Pholas —. Sp. indet. $b$.

1 partially decayed valve was found near Panama. This is probably an undescribed species.

* A large canoe made of the trunk of a tree. 


\section{1\%. Orbicula Cumingii.}

Synonymy.

Orbicula Cumingii Brod. in Proc. Zool. Soc. Lond. p. 125. Nov. 1833.

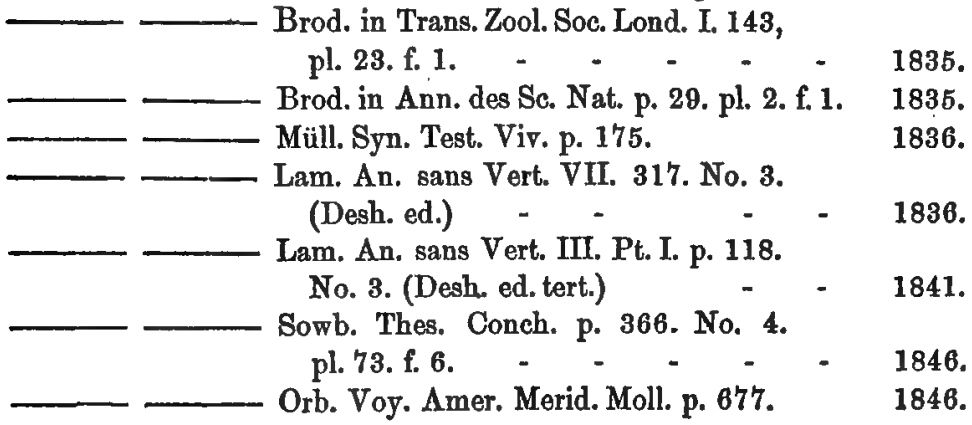

Station.-Attached to the lower sides of stones, in sandy mud, at low water, and in some instances at a depth of 6 fathoms; Cuming! Broderip.

Our specimens were also found at low water mark, attached to the under side of stones.

Habitat.-Payta, St. Elena, and Panama; Cuming I Broderip ; also Sowerby.

Payta and St. Elena; Cuming! Orbigny.

Seas of Chili and of Peru; Deshayes.

Panama; C. B. A. 1

50 specimens were collected on the reef. 


\title{
SPECIERUM NOVARUM CONCHYLIORUM,
}

\author{
IN SINU PANAMENSI REPERTORUM,
}

S Y N O P S IS.

Ovula Negleota. O. t. gracili : rubra, labro pallido: lævi, vel exilissimè spiraliter striatâ: aperturâ suprà angustâ, infrà latiore, utrinque rostratâ: labro crasso, medio recto : columellâ utrinque acuminatâ, lineâ longitudinali impressâ et callo instructâ. Long. 7.8 millim., Jat. 2.5 millim.

Ovula variabitis. O. t. gracillimâ: albidâ, vel subrufâ, labro albo: interdum rubro-purpureâ : lævi : aperturâ subangustâ, emarginatâ, infrà haud multùm latiole, suprà effusâ, haud multùm productâ : labro crasso: columellâ longitudinaliter carinatâ, suprà subbiplicatâ. Long. $13^{\prime \prime \prime} .7$ : lat. $3^{\prime \prime \prime} .8$.

Marginella minor. M. t. ovatâ : albidâ, diaphanâ : tenui, lævi : spirâ haud multùm elevatâ; anfr. circa 3 , suturâ inconspicuâ : aperturâ lineari: labro crasso, spiram adnato: columellâ plicis duobus magnis, unâ parvâ, interdum alterâ obsoletâ, instructâ. Long. 2"'.3 : lat. $1^{\prime \prime \prime} .6$.

Mitra solitaria. M. t. gracili, fusiformi : atro-fuscâ, plicis pallidis : costis transversis, parvis, plurimis, infrà obsoletis, et striis spiralibus, suprà exilioribus, intersectionibus granulatis : apice acutâ : anfr. 10, subconvexis, suturâ subimpressâ : aperturâ longâ, canali brevi : labro crasso, intùs plicis acutis plurimis instructo, suprà sinuato: columellâ quadriplicatâ. Long. $17^{\prime \prime \prime} .3$; lat. $5^{\prime \prime \prime} .7$; apert. long. $8^{\prime \prime \prime} .6$.

Oliva rnoonspious. O. t. gracili : ullida: lavi : spirâ aperturam subsequante: apico subobtusâ : anfi. 6 , suturâ conspicuâ : aperturâ suprà acuninath, latè sod non profundò emarginatâ: labro tonui. Div. $30^{\circ}$ ad $40^{\circ}$ : long. $3^{\prime \prime \prime} .8$; lat. $1^{\prime \prime \prime} .4$.

Nassa oanesorns. N. t. subelongatâ, ovato-conicâ: pallidè fuscá, ad costarum interstitia canescente: costis angustis, 10 vel 11; lineis elevatis spiralibus haud interuptis plurimis: spirâ subconicâ: apice acutâ : anfr. 8 vel 9, mediis subangulatis ; suturâ conspicuâ : labro subacuto, a varice crasso firmato: labio exilè rugoso : aperturâ latè et profúndè emarginată. Div. $50^{\circ}$; long. $20^{\prime \prime \prime} .7$; lat. $15^{\prime \prime \prime} .2$; spiræ long. $15^{\prime \prime \prime} .2$. 
Nassa collaria. N. t. ovato-conica : albidâ, fasciis fuscis nigrescentibus duobus ornatâ: costis 10 vel 12 , prope labrum minoribus et crebrioribus ; lineis elevatis spiralibus pluribus; intersectionibus subnodulosis: spirâ subconicâ : apice acutâ : anfr. 7. subconvexis ; suturâ conspicuâ: labro subacuto, a varice crasso firmato, intus crenulato: aperturấ profundè emarginatâ. Div. $50^{\circ}$; long. $7^{\prime \prime \prime} .8$; lat. $5^{\prime \prime \prime} .3$; spiræ long. $15^{\prime \prime \prime} .8$.

Nassa corpulinta. N. t. ovato-conicâ, ventricosa : fusco et albo spiraliter fasciatâ; aperturâ albâ: costis angustis 11, a lineis elevatis spiralibus trajectis: spirâ conicâ : apico acutâ : anfr. 9, subconvexis; suturâ conspicuâ; anfr. ultimo magno, ventricoso: labro subacuto, a varice crasso firmato, intus sulcato : labio rugoso: aperturd latè et profundò emarginatâ. Div. $40^{\circ}$; long. $22^{\prime \prime \prime} .4$; lat. $16^{\prime \prime \prime}$; spiræe long. $11^{\prime \prime \prime} .6$.

Nassa Gemmoloba. N. t. ovato-conicâ, ventricosâ: albidâ, flavulâ ; linê̂ fuscâ infrasuturali, alterâ anteriore, et ad anfr. ultimum medium paucis interruptis, - ornatâ: costis minimis 15 vel 16 ; lineis elevatis spiralibus; intersectionibus eleganter nodulosis : spirâ conicâ : apice peracutấ: anfr. 7, subconvexis; suturâ conspicuấ : labro subacuto, â varice crasso firmato, intus sulcato: aperturâ profundè emarginat $\hat{\hat{A}}$. Div. $56^{\circ}$; long. $5^{\prime \prime \prime} .2$; lat. $2^{\prime \prime \prime} .7$; spiræ long. $3^{\prime \prime \prime} .8$.

Nassa gladCA: N. t. ovato-conica, ventricosâ : glaucấ, fasciâ albidâ suprasuturali ornatí: costis 10, 2 vel 3 ultimis obsoletis; spiraliter striatâ : spirâ subconicâ : apice acutâ : anfr. subconvexis; suturâ conspicuâ ; anfr. ultimo ventricoso : labro subacuto, a varice crảsso firmato, intus carinis 5 instructis: aperturâ profundè emarginatâ. Div. 55 long. $12^{\prime \prime \prime} .7$; lat. $7^{\prime \prime \prime} .9$; spiræ long. $5^{\prime \prime \prime} .3_{3}$

Nassa Panamensis. N. t. elongatâ, ovato-conicâ : olivaceá, coeruleo tinctâ, lineâ albidâ spiraliter fasciatâ ; labro suprà albido: costis 11, angustis, acutis, anteriùs obsoletis; striis exilibus, spiralibus : spirâ subconoideâ: apice acutA : anfr. 8 , subconvexis ; suturâ conspicuA; anfr. ultimo parvo: labro subacuto, a varice crasso firmato, intus sulcato : apertura profundè emarginatâ. Div. $37^{\circ}$; long. $14^{\prime \prime \prime} .7$; lat. $6^{\prime \prime \prime} .3$; spiræ lon. $8^{\prime \prime \prime} .8$.

Nassa proxima. N. t. Nassce versicolori (v. infrà) simili, exiliore, costis minùs prominentibus, striis continuis exilissimis creberrimè insculptâ. Div. $38^{\circ}$; long. $11^{\prime \prime \prime} .2$; lat. $5^{\prime \prime \prime} .3$; spiræ long. $7^{\prime \prime \prime} .1$.

NAssa striata. N. t. elongata, ovato-conica: albidâ, flavo tinctâ; apertura alba : costis parvis 12 vel 13 ; striis magnis, spiralibus, multis; spirA subconoideâ : apice acuta : anfr. 8 , convexis ; suturâ subprofundá : labro subacuto, a varice lato firmato, intus sulcato: labio birugoso: aperturá profundè emarginatá. Div. $48^{\circ}$; long. $14^{\prime \prime \prime} .7$; lat. $7^{\prime \prime \prime} .9$; spiræ long. $8^{\prime \prime \prime} .4$.

NAssa versicolor. N. t. elongatá, ovato-conicâ : flavilâ, vel albida, sutura atro-fuscâ, vel omnino atro-fusca : costis angustis prominentibus, 9 vel 10 ; striis exilibus, spiralibus, ad anfr. medios evanescentibus : spirâ subconich: apice acuta : anfr. 8 , subconvexis; sutura profunda: labro subacuto, a varice robusto incrassato: labio exilè jugoso : aperturâ pro- 
fundè emarginatâ. Div. $45^{\circ}$; long. $15^{\prime \prime \prime} .2$; lat. $8^{\prime \prime \prime} .4$; spiræ long. $8^{\prime \prime \prime} .8$.

NASSA WILsoni. N. t. ovato-conicâ, ventricosâ : atro-fuscâ, fasciâ suprasuturali albidâ ornatâ : costis parvis, 16 ad 20 ; lineis elevatis spiralibus multis : spirâ conoideâ : apice acutâ : anfr. 7, subconvexis ; suturâ conspicuâ; anfr. ultimo ventricoso: labro subacuto, extus et intus incrassato, carinis paucis instructo: apertura profundè emarginatâ. Div. $58^{\circ}$; long. $8^{\prime \prime \prime} .1$; lat. $4^{\prime \prime \prime} .8$; spiræ long. $4^{\prime \prime \prime} .6$.

Buconnum luaubre. B. t. elongatâ, ovato-fusiformi ; atrofuscâ : costis parvis, 9 usque ad 13 ad singulos anfi. a striis spiralibus inequalibus decussatis, intersectionibus nonnullis acutè nodatis: apice acutâ: spirâ conicâ : anfractibus 8 , convexis, suturâ haud valdè impressâ : aperturâ ovatâ : labro acuto: canali brevì recurvâ. Div. $44^{\circ}$ : long. $17^{\prime \prime \prime}$; lat. $7^{\prime \prime \prime}$; spirx long. $10^{\prime \prime \prime}$.

Buccinum Stimpsonianum. B. t. elongatâ, ovato-conicâ : atro-cinereâ, labro suprà albido, sæepe albo-fasciatâ: rugis transversis crassis, 7 vel 8 ad singulos anfir. et rugis angustis spiralibus, quorum conspicuis ad penultimum anfr. 4, infrà minoribus; striis spiralibus exilibus plurimis : apice acutâ : spirâ conicâ : anfi. $8:$ aperturâ ovatâ : labro crasso, intùs plicis paucis instructo : columellâ rugosâ : canali brevi, valdè emarginatâ. Div. $38^{\circ}$; long. $18^{\prime \prime \prime} .3$; lat. $8^{\prime \prime \prime} .1$.

Purpura foveolata. P. t. obliquè rhombica: albidâ ; rugis transversis, magnis, compressis, 9 ad singulos anfr., et carinis 4 , elevatis, angustis; intersectionibus elevatis; striis spiralibus exilibus: apice acutâ : anfr. 6, suprà et infrà concavis, medỉis carinatis, suturâ inconspictâ : aperturâ elongatâ : labro tenui, a carinis pectinato, a striis spiralibus serrato. Div. $70^{\circ}$; long. $10^{\prime \prime \prime} .9$; lat. $7^{\prime \prime \prime} .1$.

Purpura osculans. P. t. obliquè rhombicâ: sordidè albâ, intus niveâ : rugis transversis, convexis, prominentibus, 9 ad singulos anfr., et rugis spiralibus, a striis disjunctis, creberrimè imbricatim squamosis, rugas transversas superantibus, alternis majoribus : apice acutâ: spirá conicâ; anfi. $6 \frac{1}{2}$, convexis, suturâ impressâ ; aperturâ obovatâ : labro exilè pectinato, intus transversè sulcato ; canali brevissima, profundè emarginatâ. Div. $70^{\circ}$; long. $6^{\prime \prime \prime} .86$; lat. $4^{\prime \prime \prime} .3$; spirxe long. $3^{\prime \prime \prime}$.

Coldmelza consproua. C. t. ovato-conicâ: fasciâ albâ latâ ad medios anfr., utrinque fasciâ fusco-aurantiâ latâ ornatâ ; infrà albâ, fusco maculatâ ; rugis alternis maculâ fuscâ conspicuis : rugis transversis, 9 ad singulos anfr., maximis, obtusis, ad summos anfr. obsoletis: striis magnis spiralibus rugas propò superantibus: apice subacutâ: spirá subconica : anfi. 8, convexis, suturâ haud multùm impressâ ; anfr. ultimo subangulato: aperturâ suprà haud multùn latiore, latò ol profundò omarginatâ : labro subincrassato, intùs rugoso. Div. $35^{\circ}$; long. $5^{\prime \prime \prime} .3$; lat. $2^{\prime \prime \prime} .5$; spiræ long. $3^{\prime \prime \prime}$.

Columbela diminuta. C. t. subfusiformi : pallidè flavo-fusca, infrà nigrescente: costatâ, spiraliter striatâ: striis costas hand superantibus, infrà majoribus; costis infrà obsoletis : apice acutâ : spirâ conicâ : anfr. 7, suturâ parum impressâ : aperturâ subangustâ : labro valdè incrassato, 
intùs crenulato: labio subgranuloso. Div. $45^{\circ}$; long. $3^{\prime \prime \prime} .9$; lat. $1^{\prime \prime \prime} .8$; spiræ long. $2^{\prime \prime \prime}$.

Columbelia gracilis. C. t. elongatá, ovato-conicá : suprà pallidè fuscâ, infrà rubro-fusco irregulariter maculatâ, a lineâ albo et fusco articulatâ fasciatâ : costis parvis, plurimis ; infrà spiraliter striata : apice acutấ; spirấ conicâ : anfr. 8, suturâ conspicuâ: labro crasso, intus sparsè granulato, suprà subsinuato: columellâ sublæavi. Div. $37^{\circ}$; long. $y^{\prime \prime \prime} .6$; lat. $3^{\prime \prime \prime} .2$; spiræ long. $5 "$ "'.1.

Columaelea маввт. C. t. gracili, subfusiformi : atrá vel atrofusca : suprì sublxvi ; medí costatt, costis 12 usque ad 15 ad singulos anfr., costarum intervallis spiraliter striatis ; costis et striis ad ultimum anfr. obsolctis : apice acuta : spira gracillima : anfr. 8, suturâ parum impressâ : aperturd lineari : labro valdò incrassato, suprà sinuato, intùs crenulato: columella sublevi. Div. $35^{\circ}$; long. $7^{\prime \prime \prime} .6$; lat. $2^{\prime \prime \prime} .8$; spirx long. $4 " \prime \prime 3$.

Coldmbella pulchrior. C. t. subelongatâ, ovatâ : diaphanê, pallidè flavo-fuscâ, fasciâ albâ atro-cinereo articulatẩ infrasuturali, et punctis minimis rubrofuscis quincuncialiter dispositis ornatá : lævi, nitida : apice acutâ : spirâ conicá; anfr. 6 vel 7, suturấ parum impressâ : aperturâ angustâ : labro crasso, intùs sparsè granulato: columellâ sublævi. Div. $45^{\circ}$; long. $3^{\prime \prime \prime} .8$; lat. $1^{\prime \prime \prime} .8$; spiræ long. $1^{\prime \prime \prime} .9$.

Coldmbelia tessedata. C. t. subelongatâ, ovatâ ; atro-glaucâ, fusco tinctâ; albo tesselatâ : costis approximatis, validis, circa 15 ad singulos anfr.; striis spiralibus profundis : apice acutÂ: spirâ conicA : anfi. 8 , suturâ conspicuâ : aperturâ elongatâ : labro crasso, suprà subsinuato, intùs sparsè granulato: labio subgranuloso. Div. $48^{\circ}$; long. $5^{\prime \prime \prime} .7$; lat. $2^{\prime \prime} .7$; spiræe long. $3^{\prime \prime \prime} .3$.

Ricinula jugosa. R. t. rhombica : perfusca, tuberculis albidis, vel rufis, infrà albo-fasciatâ : rugis transversis, elevatis, 8 rel 9 , a rugis spiralibus 10 vel 11 , quorum 3 vel 4 ad spiram videntur,-decussatis; intersectionibus tuberculatis; striis exilibus spiralibus : apice acuta : spirå conica : anfr. 8 vel 9 , convexis, suturâ parùm impressấ : aperturâ elongatâ : labro a rugis spiralibus pectinato, intùs plicato: labio suprà concarâ, infrà sparsè rugosá et granulatá : canali subelongata. Div. $65^{\circ}$; long. $23^{\prime \prime \prime} .9$; lat. $11^{\prime \prime \prime} .9$.

Triton fusondes. T. t. gracili, ovato-fusiformi : albidâ, fusco tinctâ, albo fasciatâ : costis distantibus, angustis, elevatis, 9 ad singulos anfr., a lineis elevatis spiralibus exilibus, alternis majoribus,-decussatis : apice acutâ : spirấ conicâ : anfr. 8, convexis, suturấ impressá; aperturâ elongatâ : canali brevi. Div. $35^{\circ}$; long. $19^{\prime \prime \prime} .3$; lat. $7^{\prime \prime \prime} .1$.

Fusus BeLLus. F. t. sub-elongatâ, fusiformi : alba, maculis rubro-fuscis, plerumque in seriebus tribus spiralibus-dispositis : costis subangustis elevatis, circa 10 ad singulos anfr., quarum nounullæ varices simulantur, et lineis elevatis spiralibus, intersectionibus nodulosis, et striis spiralibus: apice acutâ : spirầ conicâ; anfr. 7 , perconvexis, suturâ parum impressâ : aperturâ elongatâ: canali latâ, subelongata. Div. $50^{\circ} ;$ long. $11^{\prime \prime \prime} .2$; Lat. 5 "'.2; spiræ long. 5 "'.6. 
Canoglania afrinis. C. t. ovato-fusiformi : fuscâ, interdum albo unifasciata vel bifasciatâ; rugis transversis angustis, elevatis, inequidistantibus, circa 30 ad singulos anfr.; lineis elevatis spiralibus plurimis, quarum 5 ad spiram videntur : apice subacuta : spirấ conicâ : anfr. 6 , suturâ subcaniculatâ : aperturâ semiobovatâ, intùs ad dextram partem carinis acutis instructâ : labro acuto, pectinato : columellầ validâ, triplicatâ, plicâ superiore magnâ lamelliforme, inferiore parvâ et perobliquâ : canali brevi. Div. $68^{\circ}$; long. $20^{\prime \prime \prime} .7$; lat. $10^{\prime \prime \prime} .5$; spira long. $11^{\prime \prime} .4$;

Canchllaria pygmaa. C. $t$. subovatâ, brevi : pallidè cerinâ, suprà atrofusco irregulariter radiatâ, punctis atrofuscis ad costas dispositis: costis elevatis, angustis, ad anfr. ultimum 9, suprà crebris, plurimis, ad angulum anfr. majoribus; lineis elevatis, spiralibus, ad intersectiones majoribus: striis spiralibus exilissimis: apice șubacutâ: spirâ conicâ ; anfr. 5, acutè angulatis, suprà latè concavis, suturâ conspicuâ : aperturâ triangulari, infrà effusâ: columellâ biplicatâ: umbilico angusto, profundo. Div. $100^{\circ}$; long. $8^{\prime \prime \prime} .4$; lat. $6^{\prime \prime \prime} .3$; spiræ long. $3^{\prime \prime \prime} .8$.

Pleurotoma atrior. P. t. subfusiformi : aterrimâ, fasciâ pallidâ : supra suturam granulis in serie spirali dispositis; supra medios anfr. carinatâ; anfr. ultimo carinis tribus alteris spiralibus instructo: apice peracutâ: spirâ conoideâ : anfr. 11, angulatis, infra concavâ, suturâ inconspicuá: aperturâ elongatá: sinu subprofundo : canali brevi, latá. Div. $38^{\circ}$ : long. $20^{\prime \prime \prime} .3$; lat. $T^{\prime \prime \prime} .1$; spiræ long. $12^{\prime \prime \prime} .7$.

Pleunotoma conoinna. P. t. fusiformi : albidá, rubro-fusco tinctá: costis parvis, crebris, plurimis, prope labrum obsoletis, et striis spiralibus crebris, suprà exilioribus : apice acutâ: spirâ conoideâ : anfr. 8, mediis angulatis, suturâ parum impressâ : aperturâ lineari : labro valdè incrassato : sinu profundo, suturæ approximato : canali brevissimâ. Div. $43^{\circ}$ \& long. $10^{\prime \prime \prime} .7$; lat. $4^{\prime \prime \prime} .3$; spiræ long. $4^{\prime \prime \prime} .6$.

Pleuroroma exrgua. P. t. gracili : pallidè flavâ, lineis fuscis spiralibus, exilibus, plerumque geminatis : rugis transversis obtusis distantibus, 6 vel 7 ad singulos anfr., infrà obsoletis: apice acutâ: spirâ conoideâ: anfr. 6, convexis, suturâ impressâ: aperturâ angustâ: labro acuto, a rugâ ultimâ firmatâ: sinu profundo, suturâ approximato: canali brevissimâ. Div. $34^{\circ}$; long. $4^{\prime \prime \prime} .5$; lat. $1^{\prime \prime \prime} .5$; spiræ long. $2^{\prime \prime \prime} .5$.

Pleurotoma gemmulosa. P. t. elongatâ, subfusiformi : fúscâ, pallidè maculatâ: plicis transversis et spiralibus, creberrimis, parvis, intersectionibus valdè nodulosis : apice acutấ: spirâ conoideâ : anfr. 8 , subconvexis, suturâ haud multum impressâ : aperturá angustâ: sinu parvo: labro incrassato: canali brevissimâ. Div. $33^{\circ}$; long. $5^{\prime \prime \prime} .6$; lat. $2^{\prime \prime \prime}$; spiræe long. $3^{\prime \prime \prime} .56$.

Pleunotoma grandimaqulata. P. t. elongata, ovato-pyramidata : nigrâ, maculis (ad tuberculas) albidis magnis in serie spirali dispositis: striis spiralibis, exilissimis, infrà obsoletis; carinâ spirali acutâ infrasuturali ; infrà alterâ, tuberculatâ; anfr. ultimo carinis 4 vel 5 alteris instructo: apice acutâ: spirâ conicâ: anfr. 10, suturâ inconspicuâ : aperturâ subangustâ: labro subincrassato: sinu subprofundo: labio incras- 
sato: canali brevissimâ. Div. $38^{\circ}$; long. $24^{\prime \prime \prime} .1$; lat. $8^{\prime \prime \prime} .0$; spiræe long. $15^{\prime \prime \prime} .7$.

Pleurotoma striosa. P. t. gracili : subalbidâ, ad anfr, ultimum fusco exilè fasciatâ ; striis spiralibus creberrimis ; costis exilibus, 10 usque ad 12 ad singulos anfr.: apice acutá; spirá subconicá: anfr. 8, convexis, suturâ parum impressâ : apertựa subangustá : labro subacuto, a costấ ultimâ firmato: canali brevissimá. Div. $33^{\circ}$; long. $7^{\prime \prime \prime} .6$; lat. $2^{\prime \prime \prime} .5$; spiræ long. $5^{\prime \prime \prime} .1$.

Mangelia neglecta. M. t. subfusiformi : pallidè fusco-rubra : costis curvatis, elevatis, 8 vel 9 ad singulos anfr., et lineâ elevatâ spirali ad medios anfr., ad anfr. ultimum obsoletà ; infrà 'spiraliter striatâ: apice acuta : spirâ conoideâ: anfr. 7, subconvexis, suturâ conspicuâ : aperturâ subangustâ: labro valdè incrassato: sinu angusto: canali brevissimâ. Div. $40^{\circ}$; long. $5^{\prime \prime \prime} .1$; lat. $1^{\prime \prime \prime} .8$; spiræ long. $2^{\prime \prime \prime} .8$.

Cerithium assimilatum. C. t. prælongâ, conicâ : atro-rubra, ad carinas albo lineatim maculatâ: carinis spiralibus, tribus, perelevatis, compressis, acutis, et carinê alterÂ simili ad anfr. ultimi peripheriam, et infrà carina quintâ minori ; lineis elevatis transversis, inter carinas, exilissimis : apice acuta: spirâ conica : anfr. 16 usque ad 18, planulatis, suturâ inconspicuâ ; anfr. ultimo brevissimo : apertura ovata : labro pectinato: canali lata, brevissima. Div. $18^{\circ}$; long. $5^{\prime \prime \prime} .8$; lat. $1^{\prime \prime \prime} .5$; spirx long. $4^{\prime \prime \prime}: 8$.

Cerituium bimarginatum. C. t. elongatit, conicâ: cerind, suprà fuscatâ : carinis spiralibus duobus, suturæe approximatis et lineâ elevatâ ad medios anfr.; rugis parvis transversis, 18 ad singulos anfr.; intersectionibus valdè nodulatis; anfr. ultimi peripheriâ carinatâ; infrà lævi: apice acutâ : spirâ conicâ : anfr. 13, concavis, suturâ impressâ ; anfr. ultimo angulato, infrà concavo: aperturâ subquadratâ : columellâ spiralitex uniplicatâ: canali brevi, recurvâ. Div. $20^{\circ}$; long. $4^{\prime \prime \prime} .4$; lat. $1^{\prime \prime \prime} .4$; spiræ long. 3"'.5.

Cerithrom famelicum. C. t. elongatâ, ovato-conicâ : sordidè albidâ, fusco irregulariter maculatâ, maculis albo spiraliter exilè lineato; vel lineis fuscis et albis alternis crebris spiralibus ornatâ: carinấ angustâ spirali ad medios anfr., et rugis transversis, intersectionibus elevatis acutis ; infrà rugis duobus spiralibus granulosis instructâ; ; exilè creberrimè striatâ: apice acutâ : spirâ subconoideâ : anfr. 12, subeonvexis, suturâ parum impressâ; anfr. ultimo brevi, gibboso, infrà concavo: aperturâ magno : labio suprà transversim uniplicato: canali brevi, obliquâ. Div. $33^{\circ}$; long. $28^{\prime \prime \prime} .7$; lat. $12^{\prime \prime \prime} .7$; spiræ long. $19^{\prime \prime \prime} .1$.

Cerithiom Neglectum. C. t. elongatá ; ovato-conicâ : atro-rubrâ, ad apicem alba : carinis spiralibus elevatis tribus, et rugis transversis elevatis, ad anfr. ultimum 16 usque ad 18 , et minoribus, infrà obsoletis; intersectionibus valdè nodulatis: infrà spiraliter birugatá : apice ucutâ : spirâ conoided: anfr. 10, subconvexis, suturá inconspicua : canali brevissima, profundè emarginata. Div. $20^{\circ}$; long. $3^{\prime \prime \prime} .2$; lat. $1^{\prime \prime \prime}$; spire long. $2^{\prime \prime \prime} .3$.

Cerithiom pauperculum. C. t. gracili : pallidè corneâ : spiraliter JULY, 1852

Axx. Lra. Nat Hest 
multicarinatâ ; suprà rugis transversis, infrà evanescentibus ; intersectionibus subgranulatis: apice acutâ: spirấ subconoideâ : anfr. 8, subconvexis, suturâ parum compressấ; anfr. ultimo subelongato : aperturâ elongatâ, suprà acuminatâ : canali brevissimâ. Div. $18^{\circ}$; long. $3^{\prime \prime \prime} .3$; lat. $1^{\prime \prime \prime}$; spira long. $2^{\prime \prime \prime} .3$.

Cerimulum pulohrum. C. t. subelongatá, subconica : aterrimè fuscorubro, linế spirali flavo-albâ ad medios anfr. ornatâ: costis angustis acutis, ad singulos anfr. 40 , ad anfr. ultimum medium truncatis; varicibus robustis, $240^{\circ}$ distantibus; carinâ spirali, supra medios anfr., angustâ, acutâ : spiraliter striatâ : apice acutâ : spirâ subconoideâ : anfr. 11, suturâ profundâ: aperturâ magnâ, suprà effusâ, infrà angustè sinuatâ : labro crasso. Div. $33^{\circ}$; long. $31^{\prime \prime \prime} .8$; lat. $16^{\prime \prime \prime} .5$; spiræ long. $20^{\prime \prime \prime} .8$.

Crriterum Refriandu. C. t. subconicá : rubro-fusca, lineá spirali flavo-albâ ad medios anfr. et alterâ anteriori ornatâ ; costis summis pallidè flavis : varicibus nullis ; costis elevatis, 24 ad singulos anfr., infrà evanescentibus; infrà spiraliter striatâ : apice acutâ : spirâ subconoideâ : anfr. 15 , convexis, suturâ impressâ : aperturâ magnâ, suprà effusâ, infrà angustè sinuatá : labro crasso. Div. $28^{\circ}$; long. $39^{\prime \prime \prime} .4$; lat. $16^{\prime \prime \prime} .7$; spiræ long. $26^{\prime \prime \prime} .4$.

Cerithrum validum. C. t. conicâ: rubro-fuscâ, lineâ pallida ad medios anfr. ornatâ; varicibus rufis, interdum albidis; aperturâ albâ; rugis transversis, arcuatis elevatis, 20 ad singulos anfr., ad anfr. ultimi peripheriam truncatis; varicibus $270^{\circ}$ distantibus; carinis spiralibus 5 vel 6 ; spiraliter striatâ : apice acutâ : spirá subconoideâ : anfr. 12, convexis, suturâ impressâ; anfr. ultimo brevissimo : aperturâ infrà effusấ: labro incrassato. Div. $32^{\circ}$; long. $40^{\prime \prime \prime} .6$; lat. $19^{\prime \prime \prime} .1$; spiræ long. $29^{\prime \prime \prime} .2$.

Tripkoris alternatus. T. t. sinistrorsa, conicá : atro-rubrá, infrà albido fasciatâ : carinis spiralibus duobus suturæe approximatis, et tertia intermedia minore; rugis transversis, 25 ad singulos anfr., ad anfr. ultimi peripherian truncatis; intersectionibus valdè nodulatis : apice acutissima ; spirâ subconoideâ : anfr. 12, subplanulatis : suturâ inconspicuâ ; anfractu ultimo brevi, infrà concavâ : aperturâ rhombicâ : canali brevi, profundâ. Div. $30^{\circ}$; long. $5^{\prime \prime \prime} .1$; lat. $1^{\prime \prime \prime} .5$; spirx long. $3^{\prime \prime \prime} .9$.

Triphonis inconspiodus. $T$. $t$. sinistrorsa, ovato-fusiformi : atrorubrâ, cinerascente: carinis spiralibus tribus, nodulosis, et infia alteris 3 vel 4 subnodulosis; rugis transversis, 20 ad singulos anfr.: apice acutissimâ : spirâ conoideâ : anfr. 12, subconvexis, suturâ inconspicuâ : aperturá suprà sinuatá: canali brevi, profundâ. Div. $22^{\circ} ;$ long. $4^{\prime \prime} .2$; lat. 1 "'.4; spiræ long. 3 "'.3.

Trriphorrs InFrequens. T. t. conicâ : atro-rubrâ: carinis spiralibus tribus perelevatis compressis; rugis transversis, 16 ad singulos anfr.; infrà lævi : apice acutâ: spirâ subconicâ : anfr. 16, subplanulatis, suturâ inconspicuâ; anfi. ultimo brevissimo : labro pectinato : canali brevissimâ. Div. $20^{\circ}$; long. $3^{\prime \prime \prime} .3$; lat. $1^{\prime \prime \prime} .1$; spiræ long. $2^{\prime \prime \prime} .7$.

Cacoum piminutum. C. t. arcuatâ, gracili, haud tereti : albidâ: annulis 17 , robustis, subdistantibus, ad summam partem planulatis, et 
annulis 10, minoribus, minùs elevatis : apice laterali, haud prominente. Long. $1^{\prime \prime \prime} .5 ;$ lat. $0^{\prime \prime \prime} .46$.

Cacum enurneum. C. t. arcuata, subgracili, vix tereti : eburned: annulis 33, latis, approximatis, ad summam partem planulatis ; superioribus 4 usque ad 10, interdum inferioribus 2 vel 3 magis elevatis et minùs approximatis : apice prominente. Long. 2 "'.3 ; lat. 0"'.63.

Cocoum pirmatum. C. t. robustâ, arcuatâ, tereti : eburneâ : annulis 25 , robustis, latis, subdistantibus, ad summam partem planulatis : apice haud multum prominente. Long. 2 "' .3 ; lat. $0^{\prime \prime \prime} .78$.

Cacum Lave. C. t. areuatâ, validâ, vix tereti : albidâ : lavi, nitente: apice promineute. Long. $2^{\prime \prime \prime}$; lat. $0^{\prime \prime \prime} .68$. Var. (?) minus; t. gracili, apice minùs prominente. Long. $\mathrm{I}^{\prime \prime \prime} .57$; lat. $0^{\prime \prime \prime} .51$.

Coecum laqueatum. C. t. subarcuatâ, gracili, tereti : albidâ : longitudinaliter sulcata; sulcis haud profundis, 20: apice laterali, parum prominente. Long. $2^{\prime \prime \prime} .8$; lat. $0^{\prime \prime \prime} .71$.

Cøeum monstrosum. C. t. arcuatâ, suprà gracili, infrà robusta : eburneâ : ad superam partem annulis 18, validis, approximatis, ad summam partem planulatis-instructa ; ad inferam partem annulis 12 , robustis, elevatis, parùm approximatis : apice prominente. Long. $2^{\prime \prime \prime} .3$; lat. suprà 0 "'.46; lat. infrá $0^{\prime \prime \prime} .76$.

Cceovm parvum. C. t. arcuatá, gracili, vix tereti : albidá : annulis 15, acutis, distantibus, haud multum elevatis : apice laterali, prominente. Long. $1^{\prime \prime \prime} .65$; lat. $0^{\prime \prime \prime} .48$.

CøoUM PYGM 23, angustis, prominentibus, and summam partem planulatis : apice laterali, prominente. Long. $1^{\prime \prime \prime} .5$; lat. 0 "'.46.

Chemsitzia aculeus. C. t. gracillimâ, conicâ : alba : costis obtusis, 17 ad singulos anfr., ad anfr. ultimi peripheriam truncatis : spird conicá: anfr. 12, subconvexis, suturâ impressa : aperturâ subovatâ : labro tenui : columella vix arcuata: umbilico nullo. Div. $13^{\circ}$; long. $4^{\prime \prime \prime} .5$; lat. $1^{\prime \prime \prime}$; spiræ long. $3^{\prime \prime \prime} .6$.

Chemmitzia acuminata. C. t. subconicá: sordidè albidá : costis obliquis, 16 ad singulos anfr., ad anfr. ultimi peripheriam truncatis: opirê subconiç: anfr. 8, suprà acutè angulatis, parum convexis, sutura profundâ; anfr. ultimo elongato: aperturá subovata, suprà et infrd acutâ : labro tenui : umbilico nullo. Div. $23^{\circ}$; long. $2^{\prime \prime \prime} .8$; lat. $1^{\prime \prime \prime} .1$; spiræ long. $1^{\prime \prime \prime} .8$.

Chemnitzia afrinis. C. t. conica : flavâ : costis gracilibus, 24 ad singulos anfr., ad anfr. ultimi peripheriam truncatis: infrà levissima : spirâ subconich : anfr. 10, subconvexis, suturá impressâ : aperturâ subovatâ: labro tenui: umbilico nullo. Div. $18^{\circ}$; long. $5^{\prime \prime \prime} .3$; lat. $1^{\prime \prime \prime} .4$; epiræ long $4^{\prime \prime \prime} .1$.

Chemmitzia clatrratula. C. t. ovato-conica, prælonga: albida : costis minimis, 36 ad singulos anfr., ad anfr. ultimi peripheriam obsoletis, a lineis elevatis spiralibus, 5 vel 6 suprasuturalibus,-decussatis: apice minutissima : spirâ subconica : anfr. 8, ad summam partem plus minusvo 
angulatis, suturâ impressâ ; anfr. ultimo regulariter rolundato: aperturâ subovata : labro tenui : umbilico nullo. Div. $16^{\circ}$ : long. $3^{\prime \prime \prime} .3$; lat. $1^{\prime \prime \prime}$; spira long. $2^{\prime \prime \prime} .5$.

Chemermzia communis. C. $t$. subconicâ: sordidè albâ: rugis transversis, 22 ad anfr. penultimum, ad anfr. ultimum pluribus, infrà obsoletis; rugis spiralibus, 4 vel 5 suprasuturalibus, suprà minoribus : apice obliquá: spirấ conoideâ : anfir. 8, subconvexis, suturâ impressâ; anfr. ultimo elongato: aperturâ ovatâ, suprà acutâ, infrà latè effusâ: labro subtenui : columellá uniplicatầ; regione umbilicari haud multum iudentatâ. Div. $23^{\circ}$; long. $4^{\prime \prime \prime} .1$; lat. $1^{\prime \prime \prime} .27$; spiræ long. $2^{\prime \prime \prime} .8$.

Chemnitzia cracilion. C.t. prolongâ, conicâ : pallidè flavá : costis gracilibus, 28 ad singulos anfr., infrà truncatis; striis spiralibus paucis inconspicuis ; infra costas lineâ impressâ spirali-instructấ: spirấ subconicâ: anfr. 12, parum convexis, suturâ impressâ: aperturâ ovatâ, suprà acutâ: labro prætenui : umbilico nullo. Div. $13^{\circ}$; long. $7^{\prime \prime \prime} .8$; lat. $1^{\prime \prime \prime} .5$; spiræ long. $5^{\prime \prime \prime} .1$.

Chemnitzia major. C. t. conica : sordidè albâ: costis approximatis robustis obtusis, 24 ad singulos anfr., infrà obsoletis; striis spiralibus, exilissimis, creberrimis, haud costas superantibus : spirâ conicâ : anfr. 15, subconvexis, suturâ impressâ : aperturâ subovatâ : labro tenui : umbilico nullo. Div. $17^{\circ}$; long. $9^{\prime \prime \prime} .7$; lat. $2^{\prime \prime \prime} .3$; spira long. $7^{\prime \prime \prime} .8$.

Chemnitzia marginata. C. t. subcylindricâ: sordidè albâ : costis compressis, validis, prominentibus, 11 vel 12 ad singulos anfr.; striis spiralibus, exilibus, quarum 5 vel 6 ad anfr. penultimum videntur : apice obliquâ: anfr. 7 , marginatis, subconvexis, suturâ impressâ ; anfr. ultimo regulariter rotundato: aperturâ parvâ, ovatâ: labro tenui : umbilico nullo. Div. $28^{\circ}$; long. $2^{\prime \prime \prime} .9$; lat. $1^{\prime \prime \prime} .5$; spiræ long. $2^{\prime \prime \prime}$.

Chemnitzia Panamensis. C. t. conicâ: albidâ : costis obliquis, 27 ad singulos anfr., ad anfr. ultimi peripheriam obsoletis, infrà lævissimâ : spirâ subconicâ: anfr. 12, subconvexis, suturâ impressâ; anfr. ultimo subangulato: aperturâ ovatá: labro tenui : umbilico nullo. Div. $17^{\circ}$; long. $5^{\prime \prime \prime} .6$; lat. $1^{\prime \prime \prime} .4$; spiræ long. $4^{\prime \prime \prime} .3$.

Chemnitzia similis. C. t. conicâ : albidâ : costis subobtusis, 26 ad singulos anfr., ad anfr. ultimi peripheriam truncatis : spirâ subconicâ: anfr. 11, convexis, suturâ valdè impressá ; anfr. ultimo regulariter rotundato : aperturâ subovatâ : labro tenui : umbilico nullo. Div. $17^{\circ}$; long. $4^{\prime \prime \prime} .3$; lat. $1^{\prime \prime \prime} .1$; spirre long. $3^{\prime \prime \prime} .3$.

Chemnitria s'rriosa. C. t. conica: flavâ: costis exilibus, 40 ad singulos anfr., ad anfr. ultimi peripheriam obsoletis; striis spiralibus creberrimis : spirâ subconicâ : anfr. 10, parum convexis, suturâ impressâ; aperturâ ovatâa: labro tenui : umbilico nullo. Div. $20^{\circ}$; long. $5^{\prime \prime \prime} .3$;
lat. $1^{\prime \prime \prime} .5$; spiræ long. $4^{\prime \prime \prime} .1$.

Chemnitzia turrita. C. t. suprà conicâ, infrà cylindraceâ : albidâ : costis gracilibus, compressis, acutis, 18 ad singulos anfr., ad anfr. ultimi peripheriam truncatis; infrà spiraliter unisulcatâ : spirâ subconoideâ : anfr. 10, suprà acutè angulatis, parùm convexis, suturâ impressá; anfr. 
ultimo angulato : apertura suboratA : labro tenui : umbilico nullo. Div. $.23^{\circ}$; long. $4^{\prime \prime \prime} .7$; lat. $1^{\prime \prime \prime}$,4; spirm long. $3^{\prime \prime !} .56$.

Litronina (?) angrosтoma. 'L: 't. subellipticá : sordidè alba : sthis " spiralibus,' equidistantibus, profundis : 'apićé obtúsa : spira parvá, conoidế : anfr. $3 \frac{1}{2}$, percontexis, suturâ conspicuA: apertuira subeffúsá, semielliptica : labio recto : umbilico conspicuo. Div. $85^{\circ}$ : long. '3'"'.9; lat. $2^{\prime \prime \prime} .5$; spirm long: $1^{\prime \prime \prime} .4$.

Litrorina atrata. 'L. t.' subglobosá: atro, interdum albido mácu- lata : carinis spiralibus,jnequalibus ; plerumque ad anfr. ultimi périphériam et ad summam partem anfr. omnium præcipude carinata: apico acutâ : spirâ parvâ, subconoideâ: anfr. 4, subconvexis, suturâ'jmpressấ : aperturd lata, ovatá: umbilico minimo. Div. $65^{\circ}$ usque ad $90^{\circ}$; long. $2^{\prime \prime \prime}$; lat. $1^{\prime \prime \prime} .5$.

Litrorina dobrosa. Nov: sp.? L. to conoideâ: : coeruleâ, fasciâ subalbidâ fusco-articulata-ornatâ; intùs atro-fuscá; labro fusco et albo maculato : striís nonnullis spiralibus : apice subacutá : spirA subconoided : anfr. 6, parùm convexis, suturâ conspicuâ; anfr. "ultimo an'gulato : aperturâ ovath́, subeffusâ.: columella haud multùm dilatata. "Div. 55०; long. 6"',.3; lat. 4"'.3. An L. parvula Phil:'?

Litrorina (?) Exonvata. L. t. subelliptick : ad ápicom, ad umbilicuón, et intùs, atro-fuscá; ad partes ceteras pallidè córnea : lineis elevatis et striis exilissimis-spiralíbus : Apice subacutá : spirâ parra, conoidé̂́ : anfr. 4, angustis, suturâ conspicuầ; anfr. ultimó ventricoso : apertura subovatâ : labro acuto: columella dilatatá, incrassata : regione umbilicari profundè excavatâ : umbilico parvo. Div. $90^{\circ}$; long. $4^{\prime \prime \prime} .3$; lat. $3^{\prime \prime \prime} .3$; spiræ, ilong. $1^{\prime \prime \prime}$.

Litrorina ( () Foveata. L. t. globoso-conicâ: "sórdidè albâ, fasciá fusca, spirali, latâ,-ornata : lineis elevatis, spiralibús, nonnullis, inequidistantibus: apice subacutâ: spirâ subconoideâ : anfr. 4, subangulatí, suturd conspicuá: aperturá subovata: labró acutissimo: columellá dilataté incrassatá : regione umbilicari profundè excavatá: umbiliço profundo. Div. $80^{\circ}$; long. $4^{\prime \prime \prime} .8$; lat. $3^{\prime \prime} .8$; spiræ long. $2^{\prime \prime \prime}$.

Litrorina (?) megasoma. 'L. t. óvoideâ: sordidè albá: carinis spiralibus, parvis, 8 vel 9,3 suprasuturalibus; striis transversis, magnis profundis, equidistantibus : apice acutâ : spirâ minima, subconica : anfr. 3, angulatis, suturâ canaliculatá; anfr. ultimo magno, obliquè elongato: aperturâ subelliptiç: labro tenui : carinâ spirali umbilicum continentè : umbilico magno profundo. Div. $135^{\circ}$; long. $2^{\prime \prime \prime} .3$; lat. $2^{\prime \prime \prime} .3$; spiræ long. $0^{\prime \prime \prime} .88$.

Risson orandestina. R. t. elongata, óvato-conica: sordidè albá; costis robustis, compressis, prominentibus, 18 vel 19 ad singulos anfr., ad inferam extremitatem productis: apice acutá: spirâ subconoideá: anfr. 7, subconvexis, "suturê impresse : aperturd magna, utrinque subeffusa: labro ad mediam partem longè producto, a varico lato valdè incrassato: umbilico nullo. Div. $30^{\circ}$; long. $2^{\prime \prime \prime} .9$; lat. $1^{\prime \prime \prime} .27$; spirde long. $1^{\prime \prime \prime} .78$.

Rigsoa firmata. R. t. elongatá, ovato-conica : sordidè alba : costis JULY, 1852. 
robustis, prominentibus, 12 ad singulos anfr., ad inferam extremitatem productis: apice acutâ: spirâ conoideâa: anfr. 7, convexis, suturâ impressâ : aperturấ subovatâ, utrinque effusá: labro ad mediam partem producto, a varice crasso-firmato: umbilico nullo. Div. $30^{\circ}$; long. $4^{\prime \prime \prime} .7$; lat. $1^{\prime \prime \prime} .9$; spiræe long: $3^{\prime \prime \prime} .3$.

Rissoa roRTIs. R. t. elongatâ, ovato-conich : albidâ : costis robustis, approximatis, 22 ad singulos anfr., ad inferam extremitatem minoribus productis : apice acutâ: spirâ conoideâ: anfi. 10, subconvexis ; anfr. ultimo ventricoso: aperturâ ovatâ, profundè effusâ : labro infrà producto, crassissimo: umbilico nullo. Div. $33^{\circ}$; long. $7^{\prime \prime \prime} .4$; lat. $3^{\prime \prime \prime}$; spiræ long. $4^{\prime \prime \prime} .6$.

Rissoa (?) inoonspioua. R. t. ovato-conica : albidâ : carinis spiralibus nonnullis, infì̀ obsoletis : apice subacutâ : spirâ conoideâ : anfr. 4, perconvexis, sutura profundâ; anfi. ultimo brevi : aperturâ orbiculari, vix effusâ: labro incrassato: umbilico minutissimo. Div. $55^{\circ}$; long. $1^{\prime \prime \prime} .14$; lat. 0 "'”.76; spiræ long. $0^{\prime \prime \prime} .81$. An Cingulæ species?

Rissoa infrequens. R. t. prælongâ, ovato-conicâ: albidâ : costis perobtusis, haud multùm elevatis, confertim approximatis, 16 ad singulos anfractus; striis spiralibus, nonnullis, exilissimis : apice subacutâ: spirâ subconicâ: anfr. 7, suturâ haud multùm impressấ; anfr. ultimo elongato, subangulato: aperturâ subovatâ, vix effusâ: labro incrassato: umbilico nullo. Div. $23^{\circ}$; long. $6^{\prime \prime \prime} .1$; lat. $1^{\prime \prime \prime} .9$; spiræ long. $4^{\prime \prime \prime} .6$.

Rissoa Janus. R.t. elongatá, ovato-conicâ : albidâ: infrà spiraliter exilè striatâ; aliunde costis exilibus creberrimis ornatâ: apice acutâ: spirâ subconoideâ: anfr. 9, subconvexis, suturâ parùm impressá : aperturâ magnâ, infrà effusâ, suprà profundè effusâ: labro ad mediam partem producto, a varice robusto firmato: umbilico nullo. Div. $30^{\circ}$; long. $4^{\prime \prime \prime} .8$; lat. $1^{\prime \prime \prime} .8$; spiræe long. $2^{\prime \prime \prime} .9$.

Rissoa notadilis. R. t. elongatá, ovato-conicâ : albida : costis perelevatis, ad summam partem concavis, 14 ad singulos anfr., infrà obsoletis ; carinis spiralibus, duobus ad spiram, duobus alteris inferis : apico subobtusâ, nitidà : spirú conicâ : anfr. 6, ad summan partem acutè angulatis, aliunde planulatis, suturâ profundâ: aperturâ ovatâ: umbilico nullo. Div. $24^{\circ}$; long. $1^{\prime \prime \prime} .5$; lat. $0^{\prime \prime \prime} .68$.

Rissoa soalariformis. R. t. elongatá, ovato-conicâ : albida : costis validis, compressis, prominentibus, acutis, continuis, 11 ad singulos anfr.; striis spiralibus, exilissimis, costas ascendentibus, haud superantibus : apice acưtâ : spirâ subconoideâ : anfr. 8, convexis, suturâ impressâ : aperturâ perobliquâ, ovatâ, utrinque effusấ: labro subincrassato, ad mediam partem producto. Div. $33^{\circ}$; long. $3^{\prime \prime \prime} .3$; lat. $1^{\prime \prime \prime} .27$; spiræ long. $2^{\prime \prime \prime} .03$.

Cinatra (?) inconspioda. C. t. ovato-fusiformi; albidâ : carinis spiralibus, nonnullis, 4 ad anfr. penultimum; duobus superioribus, minoribus, et a rugis transversis decussatis : apice subacutâ: spirâ subconoideâ : anfr, 5 , haud multủm convexis, suturâ impressâ; anfr. ultimo parvo: aperturâ parvâ, ovatâ, suprà acutâ: labro subtenui : regiono 
umbilicari haud multùm indentatâ. Div. $30^{\circ}$; long. $1^{\prime \prime \prime} .65$; lat. $0^{\prime \prime \prime} .89$; spiræ long. $1^{\prime \prime \prime} .14$.

Cingula paupercula. R. t. conoided : sordidè alba, interdum flavofasciata : lævi : apice subacutá: spira subconica : anfr. 5, planulatis, suturâ impressâ : aperturâ latâ, ovatâ : labro haud multùm incrassato : umbilico minutissimo. Div. $33^{\circ}$; long. $2^{\prime \prime \prime} .16$; lat. $1^{\prime \prime \prime} .27$; spiræ long. $1^{\prime \prime \prime} .47$.

Cingula (!) Terembellum. C. t. subcylindricá ; albilá : carinis 4, spiralibus, perelevatis, acutis, compressis, quarum 2 ad spiram videntur: apice subacutá ; spirâ subconoided : anfr. 6, parùm convexis, suturâ inconspicuá; anfr. ultimo parvo: aperturá parvâ, ovata, suprà acutA: labro tenui: umbilico nullo. Div. $28^{\circ}$; long. $2^{\prime \prime \prime}$; lat. $1^{\prime \prime \prime}$; spiræ long. $1^{\prime \prime \prime} .4$.

Cingula turrita. C. t. elongatâ, conica : albida : costis prominentibus, compressis, crebris, prope suturam a striâ spirali suprasuturali truncatis; infrà spiraliter striatâ : apice acutâ : spirấ subconicâ : anfr. 6 , ad summam partem acutè angulatis, aliunde planulatis,'suturâ canalículatâ : aperturâ parvâ, ovatâ, vix effusâ : labro tenui : regione umbilicari minutissimè indentata. Div. $30^{\circ}$; long. $2^{\prime \prime \prime}$; lat. $0^{\prime \prime \prime} .74$; spirse long. $0^{\prime \prime \prime} .81$.

Litropa (?) sAxicola. L. t. elongatá, ovatá: corned, subtransparente: striis spiralibus profundis equidistantibus crebris ornata : apice acutâ: spirâ subconoideâ : anfr. 5, convexis, suturâ impressâ: anfr. ultimo ventricoso : aperturâ latâ, ovatâ, suprà acutâ: labro pretenui; umbilico nullo. Div. $45^{\circ}$; long. $3^{\prime \prime \prime} .56$; lat. $1^{\prime \prime \prime} .9$; spiræ long. $1^{\prime \prime \prime} .8$.

Adeorbis (छ) ABJECTA. A. t. subglobosâ : pallidè flavâ, vel sordidè atrâ, vel partim utriusque coloris : lineis elevatis spiralibus, et striis spiralibus ad summam partem anfr. ornatâ : apice subacutá : spirâ brevi: anfr. 3, plusve, convexis, suturâ conspicuá; anfr. ultimo ventricoso: aperturâ effusâ, semicirculari : labio recto : umbilico minimo. Div. $110^{\circ}$; long. $2^{\prime \prime \prime} .54$; lat. $2^{\prime \prime \prime} .29$; spiræ long. $1^{\prime \prime \prime} .14$.

Vițrinelea concinna. V. t. discoided: albA : carinis spiralibus, 5 , acutis; prominentibus, quarum superior infrasuturalis est, quarum inferior umbilicaris est: transversè striatâ : apice minimâ, papillari : spirâ subplanulatâ : anfr. $3 \frac{1}{2}$; ad summam partem planulatis, suturấ profundâ : aperlurâ orbiculari: labro subinerassato, a carinis subpectinato: umbilico lato, profundo. Div. $175^{\circ}$; lat. max. $1^{\prime \prime \prime} .57$; lat. min. $1^{\prime \prime \prime} .28$; alt. $0^{\prime \prime \prime} .77$.

Vitrinelta exigua. V. t. subdiscoidea : albâ: carinis spiralibus, 3, unâ superiore ad anfi. ultimi peripheriam, unâ inferiore umbilicum continente ; transversè substriatâ : apice obtusá : spirâ convexâ, haud multùim elevatá : anfr. 3, ad summam partem subangulatis, suturâ impressâ ; anfr. ultimo prope peripheriam utrinque concavo: apertura orbiculari : labro subincrassato, a carinis subpectinato: umbilico angusto, profundo. Div. $170^{\circ}$; lat. max. $1^{\prime \prime \prime} .14$; lat. min. $0^{\prime \prime \prime} .9$; alt. $0^{\prime \prime \prime} .53$.

Vitainelia $J_{\text {ANUS. }}$ V. t. subdiscoideâ : albâ : carinis spiralibus, 4, acutis, angustis; infrà exilè spiraliter striatâ ; aliunde transversè striata ; striis a carinis interruptis : apice prominente : spira haud multùm 
elevata : anfr. $3 \frac{1}{3}$, sutura conspicuâ : aperturâ orbiculari : labro subincrassato, a carinis pectinato: umbilico profundo. Div. $160^{\circ}$; lat. max. $1^{\prime \prime \prime} .7$; lat. min. $1^{\prime \prime \prime} .5$; alt. $0^{\prime \prime \prime} .76$.

Vitrinella minuta. V.t. discoideâ; sordidè albâ, nitidâ : exilissimè transversè striata : apice obtusâ : spirá parùm elevatâ : anfr. 3 , ad summam partem depressis, suturâ impressa; anfr. ultimo perdepresso, subangulato: aperturâ magnâ, orbiculari : labro haud multùm incrassato: umbilico subprofundo, partim obtecto. Div: $170^{\circ}$; lat. max. $1^{\prime \prime \prime} .01$; lat. min. $0^{\prime \prime \prime} .9$; alt. $0^{\prime \prime \prime} .43$.

Vitrinella modesta, $\nabla . t$. discoideâ: sordidè albâ, diaphanâ: lineâ elevatâ spirali, infrasuturali, et carinâ umbilicum continente, et striis nonnullis exilissimis ad anfr. ultimi peripheriam,-instructâ : apice haud prominente : spirâ convexâ, haud multùm elevatâ : anfr. $3 \frac{1}{2}$, suturâ conspícuá: aperturâ orbiculari : umbilico profundo. Div. $170^{\circ}$ : lat. max. $1^{\prime \prime \prime} .52$; lat. min. $1^{i \prime \prime} .27$; alt. $0^{\prime \prime \prime} .7$.

Vitrinella Panamensis. V.t. subdiscoideá : albâ: carinis spiralibus, 3 , superiore robustá, inferiore plerumque parva, umbilicum continente; costis arcustis, subdistantibus : apice obtusâ : spirâ convexâ, haud multùm elevatâ: anfr. 3, suturâ conspicuá; aperturấ orbiculari :'labro subincrassato, a carinis subpectinato: umbilico augusto, profundo. Div. $160^{\circ}$; lat. max. $1^{\prime \prime \prime} .78$; lat. min. $1^{\prime \prime \prime} .52$; alt. $1^{\prime \prime \prime}$.

Vitrinella Parva. V.t. subdiscoideâ: albâ : costis robustis pluribus firmatâ; carinis spiralibus prope anfr. ultimi peripheriam, utrinque uná : apice perobtusâ : spirâ convexâ, vix elevatâ: anfr. $3 \frac{1}{2}$, ad summam partem angulatis, suturâ haud multùm impressâ; anfr. ultimo maximo : aperturâ orbiculari : labro haud multùm incrassato: umbilico angusto, profundo. Div. $160^{\circ}$; lat. max. $1^{\prime \prime \prime} .18$; lat. min. $1^{\prime \prime \prime}$; alt. $0^{\prime \prime \prime} .65$.

Vitrinella Perparva. V.t. subdiscoideâ : albâ: carinis spiralibus, prope anfr. ultimi peripheriam utrinque unâ magnâ acutâ, alterâ umbilicum continente minore; transversè rugosâ : apice obtusâ : spirâ planâ: anfr. 3, subconvexis, sutura conspicuá; anfr. ultimo maximo: aperturá orbiculari: labro haud multùm incrassato: umbilico profundo. Div. $180^{\circ}$; lat. $\max .0^{\prime \prime \prime} .94$; lat. min. $0^{\prime \prime \prime} .79$; alt. $0^{\prime \prime \prime} .38$.

Vițrinella regolaris. V. t. subdiscoideâ : albidâ, margaritaceâ : lævi, nitidâ ; striâ infrasuturali unâ impressâ : apice subacutâ : spirâ convexâ, suturấ conspicuâ: aperturâ suborbiculari: labro tenui : regione umbilicari profundè indentatâ. Div, $120^{\circ}$; lat. max. $1^{\prime \prime \prime} .78$; lat. min. $1^{\prime \prime \prime} .52$; alt. $1^{\prime \prime \prime} .27$.

Vitrinella seminuda. V. t. discoideâ: albâ: suprà exilissimè transversè striatâ : infrà spiraliter striatâ: apice obtusâ: spirấ convexâ, vix elevatâ: anfr. 3 , subconvexis, suturâ conspicuâ; anfr. ultimo subangulato': aperturd orbiculari : labro tenui : umbilico angusto, profundo, Div. $170^{\circ}$; lat. max. $1^{\prime \prime \prime} .57$; lat. min. $1^{\prime \prime \prime} .25$; alt. $0^{\prime \prime \prime} .81$.

Vitrinella tricarinata. V.t. subdiscoideá : albâ: carinis spiralibus, 3 ; striis transversis, nonnullis, irregularibus ; umbilico spiraliter striato: apice subacutâ: spirấ convexâ, haud multùm elevatâ: anfr. 3 , depressis, suturâ conspicuâ: aperturâ orbiculari, a carinis pectinato: 
umbilica lato; profundo.. Div, $160^{\circ}$; lat: max. $1^{\prime \prime \prime} .88$; lat. min. $1^{\prime \prime \prime} .65$; alt. $0^{\prime \prime \prime} .89$.

- Vrtrinela vaivatotbes. - V. t. discoidea : albida, diaphana : carinis spirálibus, 3, inferiore umbilicum continente minore: spirâ concavâ: anfr. 8 ; ad summam partem concavis; sutura conspicua ; anfr. ultimo subangulato: umbilico lato, profundo. Lat. max. $2^{\prime \prime \prime} .54$; lat. min. $1^{\prime \prime \prime .91 ; ~ a l t .1 " ' . ~}$

Trochos coronulatos:- T. t. ' conicấ, haid multùm elevatâ, crassâ : albida, flammulis latis obliquis rubro-fuscis ornatâ, ad nodulos rubellâ : lineis spiralibus elevatis exilè undulatis; infra, lineis 4 vel 5 majoribus; carinis spiralibus nodulosis ad anfr. ultini peripheriam, et nodulis majoribus infrà suturam instructâ : apice subacutâ: anfr. 6, planulatis; suturâ valdè canaliculatâ : aperturâ suborbiculari : columellá bidentatâ: umbilico magno, profundo. . Div. $90^{\circ}$; long. $14^{\prime \prime \prime}$; lat. max. $18^{\prime \prime \prime} .2$; lat. min. $15^{\prime \prime \prime} .2$.

Trochở Lanavis. T. t. conica, procera : fusca pallida, rubro vel flavido tincta ; flammulis obliquis latis atro-fuscis ornat ; infrd lineis rubro et flavo-albo articulatis, concentricis pictâ: lineis spiralibus elevatis granulosis : apice acuta : anfr: 9 ; suprà perconvexis, inftà planulatis vel concavis: aperturấ subquadratâ : labro tenui : columellá subrectâ: umbilico nullo. Div. $60^{\circ}$; long: $12^{\prime \prime \prime} .2$; lat. max. $11^{\prime \prime \prime} .2$; lat. min. $10^{\prime \prime \prime} .2$.

- Turbo (?) PHastanelud. T. t. ovato-conoideá: colore varia, plerumque rubrât vel fuscâ, interdum unicolore; plerumque flammulatâ, Interdum fasciata vel seciatim máculata: striis profundis, spiralibus, creberrimis : "upicer subacuta : spirł conoideâ : anfr. 5, convexis, suturấ conspicuâ: aperturł́ latâ, "ơatâ, subeffusá: labro tenui : umbilico minimo. Div. $64^{\circ}$; long. $4^{\prime \prime \prime} .1$; lat. $2^{\prime \prime \prime} .4$; spiræ long. $2^{\prime \prime \prime}$.

Tordo notruos. T. t. trochiformi, elevatâ': rutilâ, pallidè transversè strigatd : spiræe rugis plurimis parvis obliquis subnodulosis, a sulcis parvis spiralibus intersectis; infrà; sulcis angustis profundis concentricis 6 vel 8: spirâ subconoideâ : anfractibus planulatis ; suturd conspicuâ : anfr. ultimo angulato, anteliùs subplanulato : Jabio expanso, appresso, calloso: umbilico nullo. 'Div. $70^{\circ}$; loog. $63^{\prime \prime \prime} .5$; lat: $\max .76^{\prime \prime \prime} .2$; lat. min. $68^{\prime \prime \prime} .6$.

'Eбстмa' 1ота. E. t. subulatá: levi; nitente: lineâ microscopicâ impréssâ ; sùpra lineam lacleâ, infra lineam diaphana : apice subacutâ: spirấ valdè arcuatâ: anfr. 10, subconvexis, suturâ conspicuâ : aperturÁ parvâ, ovatá; subeffusá : Jabro ad mediam partem porrecto. Div. $20^{\circ}$; long. $2^{\prime \prime \prime}$; lat: $0^{\prime \prime \prime} .76$; spiræ long. $1^{\prime \prime \prime} .5$.

EuLima RECTA. E. t. elongatâ, orato-conica : albidâ, fasisciâ unâ opack et alterâ 'diaphana infrasuturalibus_ornatâ; ad labrum et ad gradus ætatis fusco exilè bimaculata: lævi, nitente, striis nonnullis gradus æetatis monstrantibus: apice acutissima : spird recta, conicé : anfr. 11, subplanulatis, suturâ inconspicuâ; anfr, ultimo elongato : aperturá angustâ, suprà acutissima : labro acuto: columellâ robustá; subrecta. Div. $21^{\circ}$; long. $10^{\prime \prime \prime} .3$; lat. $2^{\prime \prime \prime} .54$; spiræ long. $7^{\prime \prime \prime} .24$.

JULY, 1852

AxN. LYC. NAT, Hist. 
Eulima solitaria. E. t. elongatâ, ovato-conica : albidâ, suprà fusco tinctâ: lævi, nitente: apice acutấ: spirâ haud multùm arcuatâ, subconicâ: anfr. 11, planulatis, suturâ inconspicuâ: aperturâ ovatâ, suprà acutâ: labro acuto, ad mediam partem producto: columellâ robustâ, subarcuatâ, Div. $23^{\circ}$ : long. $4^{\prime \prime \prime} .8$; lat. $1^{\prime \prime \prime} .4$; spiræ long. $3^{\prime \prime \prime} .56$. An Stylifer ?

Prramidella contca. P. t. elongatâ, conioâ: suprà albidâ, infrà fuscâ, lineâ pallidâ suprasuturali : lævî, nitidâ : apice acutissimâ : spirâ conicâ : anfi: 14, planulatis, suturâ angustè canaliculatâ; anfi. ultimo angulato : aperturấ obliquâ : labro tenui : columellâ triplicatâ ; plicâ unâ lamelliformi, plicis duobus parvis. Div. $23^{\circ}$; long. $14^{\prime \prime \prime} .5$; lat. $4^{\prime \prime \prime} .45$; spira long. $9^{\prime \prime \prime} .65$.

Pedipes angulata. P.t. ovato-globosá : fusco-rubrá, aperturâ albá : crassâ, lineis elevatis spiralibus rugosis creberrimis inequalibus, ad summos anfr. exilioribus : apice subaculâa : spitâ conoideâ : anfr. 4, angulatis, ad summam partem concavis, ad suluram imbricatis; anfr. ultimo magno, ventricoso, subangulato: aperturâ subellipticâ : labro acutissimo, suprà subsinuato, intùs crassissimo, callo ad anfr. angulum interrupto, infrà angulum in dentem longè producio : columellâ crassâ, planâ, biplicatâ : plicis transversis, inferior minore: labio plicâ spitali lamelliformi maximâ instructo : umbilico nullo. Div. $90^{\circ}$; long. $6^{\prime \prime \prime} .35$; lat. $4^{\prime \prime \prime} .8$; spiræe long. $2^{\prime \prime \prime} .5$.

Aurioula concinna. A. t. ellipsoideâ: aíro-fuscâ, ad anfr. ultimi peripheriam pallidâ et infrà lineâ pallidè flavâ ornatâ ; plicis et callo albis : lævi, nitidâ : apice acutâ : spirâ conoideâ ; anfi. 5 , convexis, imbricatis, suturẩ parùm impressâ : aperturâ angustâ, suprà acutissimâ, a plicis contractá : labro acuto, intùs a callo crasso firmato: plicis 3 , inferiore pesobliquâ, superiore maximâ, infì̀ concavâ, suprâ dilatatâ et rugosâ. Div. $80^{\circ}$; long. $8^{\prime \prime \prime} .1$; lat. $5^{\prime \prime \prime} .1$; spir’e long. $2^{\prime \prime \prime} .3$.

Aurioula infrequens. A. t. ellipsoideâ: fusca, fascia pallidá infra. suturali: striis transversis exilibus : apice ucutâ: spirâ subconoideâ: anfi. 6 , ad summarn partem subanguluís, sutura profunda; anfr. ultimo compresso: aperturâ subellipticâ : labro tenuissimo: plicis duobus, unâ inferiore obliquâ, alterâ trausversâ. Div. $80^{\circ}$; long. $5^{\prime \prime \prime} .8 ;$ lat. $3^{\prime \prime \prime} .8$; spiræ long. 2 "'.5.

Auricula Panamensis. A. t. elongatâ, ovatâ: atro-rubrá, plicis internis albis: lævi, nitidâ, striis spiralibus propo apicem insculptâ : apice acutâ: spirâ suprì conoideâ, infrà subcylindraceâ: anfr. 8, convexis, imbricatis : aporturt subelongatâ, acutà : labro intus inermi vel uniplicnto: labio triplicato. 1)iv. $50^{\circ}$; long. $11^{\prime \prime \prime} .1$; lat. $4^{\prime \prime \prime} .3$; spirw long. $5^{\prime \prime \prime} .8$; testw alterius, $65^{\circ} ; 9^{\prime \prime \prime} .3 ; 5^{\prime \prime \prime} .1 ; 3^{\prime \prime \prime} .3$.

Aurioula Tanogensis. A. t. obovatâ : aterrimè fusco-rubrâ, columellâ rufâ, plicis et callo albis: lavi, nitidâ, suprà exilè spiraliter striatá: apice acutâ: spirấ conoideâ: anfi: 10, iṇbricatis, suturấ conspicuâ ; anfi. ultimo maximo: aperturâ prælongâ, angustâ, callo ad dextram partem transversè rugoso: plicis $3_{2}$ ad sinistram partem, superiore haud 
multùm majore, duobus alteris a sinu disjunctis. Div. 100\%; long. $15^{\prime \prime \prime}$; lat. $9^{\prime \prime \prime} .1$; spiræ long. $3^{\prime \prime \prime} .8$.

Auricula trilineata. A. to obovatâ : fusco-rubrâ, liveis albis tribus spiralibus ornatâ; columellâ rufá : striis transversis inequalibus : spirâ minimâ, conoideâ : anfr. angustis, imbricatis, suturâ conspicua ; anfr. ultimo maximo: apertura prelongâ, angustá : labro intùs calloso et transversè plicato: infrà ad columellam plict unâ tortâ, suprà hanc alterâ transversâ magnâ (his a sinu disjunctis), suprà 4 parvis transversis approximatis. Div. $135^{\circ}$; long. $18^{\prime \prime \prime}$ : lat. $10^{\prime \prime \prime} .9$; spiræ long.

Trunoatelia Bairdiana. A. t. cylindraceâ : succineâ, aurantiâ: costis parvis creberrimis, post labrum obsoletis, ad anfr. penultimum 24 : apice acutA, truncata, anfi. 4 deperditis: spira subconoided: anfr. reliquis 4, convexis, suturá impressâ : aperturè ovatá, suprà baud multùm effusa : labro reflero, duplici : labio calloso. Div. ad med. $22^{\circ}$; long. (testæ truncatæ) $55^{\prime \prime \prime} .3$; lat. $1 "{ }^{\prime \prime} .9$; spiræ long. $3^{\prime \prime \prime} .8$.

Trunoatelea (??) Dubiosa. T. t. ovato-conicâ: diaphana, flavofuscâ : tenui, lavi, nitente: apice subacutá : spirâ subconoideâ : anfr. 6 , convexis, suturd impressa ; anfr. ultimo brevi, ventricoso : apertur'a lata, ovata : labro tenui : labio infrà subreflexo. Div. $45^{\circ}$; long. $2^{\prime \prime \prime} .8$; lat. $1^{\prime \prime \prime} .4$; spiræ long. $1^{\prime \prime \prime} .14$.

Bulla INFREquens. B. t. cylindraceâ : albâ: lavi : apice minutissima, prominente, papillari : spirâ elevatâ, convexâ : anfr. $4 \frac{1}{2}$, ad summam partem aculé angulatis, suturâ canaliculata : aperturâ prolongâ, angusta ; labro tenuissimo: columellâ in plicam spiralem robustam desinente. Div. $130^{\circ}$; long. $7^{\prime \prime \prime} .1$; lat. $2^{\prime \prime \prime} .8$; spiræ long. $0^{\prime \prime \prime} .76$.

Bulla luticol.A. B. t. subcylindracea, infrà latiore: diaphana, pallidè corneâ : striiis transversis exilissimis : spirâ umbilicatâ, a labro partim tectâ: anfr. ultimo constricto: aperturâ suprà spiram productâ, suprà lineari, infrà suborbiculari : Jabro tenuissimo: columellâ callosâ: infrà regione umbilicari indentatá. Long. 5 "'.1; lat. $2^{\prime \prime \prime} .4$.

Stomatella inflata. S. t. obliquè ellipticâ : albâ, jnfrè crassâ et opacâ, suprà tenui et diaphanâ : striís transversis inequalibus exilissimis; striis spiralibus nullis : apice minimâ, obtusâ, prominente: anfr. 2, perconvexís, suturâ impressấ; anfr. ultimo ventricoso: aperturâ contractâ, columellam usque ad apicem monstrante: labio profundè arcuato. Long. (obliquè) 21 "'.4; lat. $7^{\prime \prime \prime} .9$.

Calyptren aberrans. C. t. subconcavâ : papyratiâ, margaritacea : striis transversis exilibus inequalibus : apice minima, subterminali : cyatho tenuissimo, angusto, concavo, transverso, sub apice. Long. $17^{\prime \prime \prime} .8$; lat. $15^{\prime \prime \prime} .6$.

Calyptrea (Strphopatelia) asperga. C. t. conicâ : tenui : sordidè vel subfusco-albidâ, maculis pluribus rubro-fuscis irregulariter aspersâ : rugis brevissimis minimis inequalibus minimè elevatis : apice acutẩ, centrali : laminâ replicata,-plicâ ad latus interius appressâ et tubum formante, - lata, per $240^{\circ}$ revolvente: limbo tenuissimo, acuto. Diam. $14^{\prime \prime \prime}$; alt. $5^{\prime \prime \prime} .23$. 


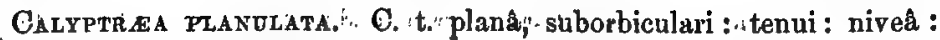
striis radiantibus, exilissimis, prope apicem obsoletis : apice subcentrali, acutâ, haud multùm elevatấ : cyatho libero, angulis acutis, tenui, per $220^{\circ}$ arcuato ! limbo tenuissimo.: Long. $8^{\prime \prime \prime} .1$; lat. $8^{\prime \prime \prime} .9$.

$\therefore$ Calyrerta (Syphopatella) regularis.: C. t. conicâ : subincrassatâ : niveâ, propes apicem sublusco tinctâ : 'striis concentricis, exilissimis, leviter impressis ; njilidâ : apice subacutâ, subcentrali : laminâ replicatâ, tubum parrum formante, ductâ : limbo acuito. Diam. $32^{\prime \prime \prime} .2$; ult. $14^{\prime \prime \prime}$.

Crepidula cerithicola. C. t. ovatá, convexâ: posteà albidâ, radiis duobus' Jatis fusco-rubris ; anteriìs diaphanâ, palliclè fusco-rubıá, fuscorubro'radiatâ; intérdum subunicolore; septo albo: levi s. apice acutá, terminali :'septo ad sinistram partem angustè sinuato, ad-mediam latè sinuato; ad dextram haud sinuato. Long. ${ }^{\prime \prime \prime} .84$; lat. $3^{\prime \prime \prime} .56 ; \sin .1^{\prime \prime \prime} .78$.

CReipidua Nivea. C. t. ovato-ellipticá : subincrassatâ: intụ niveâ, extus sordidè albâ: irregulariter concentrịcè plus minusve rugơâ, concentricè conspicuè'striatấ:- apice dextror'sum deflectâ, subprominente, marginalis.septo longitudinaliter subangulato, ad sinistram profundè et ad dextrum haud profundè sinuato: limbo crasso; crebrè-striato. Long. $35^{\prime \prime \prime} .5$; lat. 25.4 ; alt. $10^{\prime \prime \prime} .1$.

Crepidula osoulans. C. t. ellipticâ : tenui : pallidè corneâ, diaphanâ : rugis minimis concentricis et radiatis decussatâ; apice subterminali, 'multùm prominentè, haud marginali ; nuoleo nitente, transparente, dextrorsum vix deflecto : septo juxta limbum affixo, minimo, lineæ curvatæ: forma : limbo tenuissimo. "Long $3^{\prime \prime \prime} .56$; lat. $2^{\prime \prime \prime} .55$; lat. $1^{\prime \prime \prime} .02$.

Greptobla rostrata: "C. t.' makimè convexâ, subellipticâ : lividofuscâ: rugis inequalibus haud prominentibus radiatis et concentricis: apice acutissima, maximè prominente, rostriformi, a limbo multùm disjunctâ, dextrorsum vix deflecto: septo profundè affixo, planulato, plerumque declivi: limbo - tenui, contorto. Long. $12^{\prime \prime \prime} .2$; lat. $7^{\prime \prime \prime} .6$; alt. $7^{\prime \prime \prime} .37$.

Frssurella alta. C. t. subconica, altå : sordidè albâ, radius latis atro-cinereis picta : costis radiatis, alternis majoribus; rugis concentricis crebris : apice subanteriore: : fissurâ parvâ, ovato-ellipticâ : limbo pectinato. Long. $10^{\prime \prime \prime} .67$; lat. $7^{\prime \prime \prime} .36$; alt. $5^{\prime \prime \prime} .6$.

A romia tenuis. A. t. orbiculari : planatâ, tenuissimâ: alba, subtranspaiente; margaritaceâ: ' oicatrice superiore maguâ, subcirculari, infrd sinuata; cicatricibus 'duobus inferioribus parvis; circularibus, equalibus, approximatis, quarum anterior prope superioris isinun posita est; posterioris vertice parti media anterioris exequante. Diam. 33"'.

Criama Buddrana. C. t. orbiculari vel subtriangulari : extus, et intus ad limbum, purpureo-rubrâ, spinis albis : striis radiantibus interruptis; valvâ superiore'spinis brevibus crassis triangularibus forntcatis ornatá; valvâ inferiore quoad $\frac{2}{3}$ vel $\frac{3}{4}$ ad rupem affixa, 'aliter spinis dentiformibus ornatâ ; limbis exilè et profundè crenulatis : apicibus submarginalibus.
Diam. $76^{\prime \prime \prime}$. 
Arga pholadiformis. A. t. pholadiformi, vix hiante : albidá : exilè clathratâ ; intersectionibus nodosis, infrà striosis : umbonibus planulatis, posticè valde angulatis; rugis radiantibus ad angulum divaricatis: apjcibus parvis : areh ligamenti lineari: limbis exilè cremulatis: dentibus ad mediam seriem obsoletis. Long. $31^{\prime \prime \prime} .7$; alt. $19^{\prime \prime \prime} .4$; lat. $12^{\prime \prime \prime .2 . ~}$

Arca simnus. A. t. subelliptica, inequilaterali, subauriculata; margine inferiori subrecta : marginibus anticè et posticè rotundatis ; margine dorsali vix obliquâ: albâ: epidermide virescente-fuscâ in æatate juniori, nigro-fusck in ætate adulta : costis $40-44$, posterioribus majoribus et acutè angulatis : umbonibus prominentibus, planulatis, haud angulatis : areâ liganenti angusta, depressâ; marginibus intùs a costis pectinatis; dentibus parvis. A. tuberculosos Sowb. similis. Long. $55^{\prime \prime \prime} .9$; alt. $33^{\prime \prime \prime}$; lat. $27^{\prime \prime \prime} .9$.

Arca Tabogensis. A. t. subelongata, subinequilaterali : margine inferiori haud multùm hiante, subrecta; margine posteriori subrectA, obliquâ; margine anteriori rotundatâ : albidâ ; epidermide atro-fuscấ: costis radiantibus plurimis, perangustis, inequalibus ; rugis concentricis obsoletis: umbonibus planulatis, area ligamenti angustâ, anteriùs latiore: limbis exilè et inequaliter crenulatis: dentibus ad mediam seriem parvis : epidermide subpilos丸 vel lamellosa. Long. $33^{\prime \prime \prime}$; alt. $21^{\prime \prime \prime} .6$; at. $16^{\prime \prime \prime} .5$.

Crteerea congandoinea. C. t. obovate, subcordata, infred rotundata : pallidè straminea, radiis flavo-fuscis, angustis, irregulariter interruptis, ad marginem haud productis : lævi, nitidẩ: apicibus approximatis, prominentibus: arể posteriori distinctâ, elongat $\hat{\text { a }}$ striatâ : lunulâ cordiformi, striatâ : limbis haud crenulatis. Long. $31^{\prime \prime \prime} .7$; alt. $25^{\prime \prime \prime}: 4$; lat. $17^{\prime \prime \prime} .3$.

Gouldia Pacifica. G. t. subtriangulari, infrâ rotundatâ : variè coloratâ, albidâ, vel pallidè fusct, apicibus plurium rubro tinctis ; fusco interdum radiatim vel rariùs concentricè lineat usque ad 12 ; interdum radiatim striatâ : apicibus acutissimis perapproximatis : lunulâ distinctá $:$ limbis haud crenulatis. Long. $5^{\prime \prime \prime} .6$; alt. $4^{\prime \prime \prime} .8$; lat. $2^{\prime \prime \prime} .3$.

Crrena martima. C. t. subtriangulari, infrà rotundatâ, ventricosâ, subtenui : albida, posticè violaceâ : epidermide olivaceâ, asperè concentricè striatâ: umbonibus inflatis, posteriùs biangulatis, angulo tertio intermedio obsoleto : lunulâ latâ, profundâ : ligamento magno: limbis tenuibus: dentibus omnibus magnis. Long. $68^{\prime \prime \prime} .6$; alt. $57^{\prime \prime \prime} .1$; lat. $4 \theta^{\prime \prime \prime} .6$.

Donax Rostratus. D. t. elongata, inequilaterali, anticè rostratâ, supra carinam concavd : margine ventrali ad mediam rotundata, antice recta : margine anteriori perobliqua, subrecta : purpureo et sordido flavo zonatá : suprà et posteriùs læri nitida ; ad mediam striis exilibus distantibus radiata; anteriùs profundiùs et crebriùs striata : apicibus parvis, prominulis : umbonibus anticè acutè carinatis: limbis anteriùs et infrà crenulatis: dentibus lateralibus utrinque magnis. Long. $40^{\prime \prime \prime} .6$; alt. $29^{\prime \prime \prime} .2$; 1at. $20^{\prime \prime \prime} .2$.

Teluina cograta. T. t. subellipticâ, solida, convexa, subequilaterali ; JULY, 1852. 
margine ventrali subrotundatá; margine anteriore latè rotundatâ: margine dorsali anticè subrectâ, declivi, posticè subconcavâ, declivi; parte posticá obliquè et latè truncatâ: flexurâ parvâ : albâ, rubro vel fusco tinctâ: striis exilissimis inequalibus radiatâ; striis exilibus subobliquis crebris, posticè deficientibus; ligamento brevi, conspicuâ : dentibus lateralibus obsoletis. Long. $44^{\prime \prime \prime} .5$; alt. $31^{\prime \prime \prime} .2$; lat. $12^{\prime \prime \prime} .7$.

Telinna ooncinna. T. t. subellipticâ, tenui, convexa, parte anticâ vix majore; margine ventrali subrotundatâ; margine anticâ latè rotundatâ; margine dorsali anteriùs vix excurvatâ, haud multùm declivi, posteriùs subrectâ, paululum declivi ; parte posticâ subobliquè latiùs truncatâ: flexurâ parvâ: nitidâ, niveâ, ad mediam partem rubellâ : striis concontricis inequalibus exilibus, posticis majoribus; striis radiantibus inequalibus exilissimis : ligamento brevi, conspicuo: dentibus lateralibus obsoletis. Long. $40^{\prime \prime \prime} .6$; alt. $25^{\prime \prime \prime}$; lat. $12^{\prime \prime \prime}$.

Tellina puella. T. t. elongatâ, subsolidâ, convexâ, subinequilaterali; margine ventrali vix excurvatâ, posticè rectà; margine antică latè rotundatâ; margine dorsali anticè vix excurvatâ, posticè rectâ, perdeclivi ; parte posticâ acuminatâ : flexurâ parvâ : albâ, prope marginem rubro tinctâ: nitida ; striis concentricis exilissimis; striis radiantibus microscopicis: ligamento parvo : dentibus lateralibus conspicuis. Long. $22^{\prime \prime \prime} .8$; alt. $12^{\prime \prime \prime} .4$; lat. $7^{\prime \prime \prime} .1$.

Telina siliqua. T. t. elongatâ, subellipticâ, tenuissimâ, inflatâ, perinequilaterali ; margine ventrali subrectâ; margine anticâ rotundatá ; margine dorsali anticè vix excurvatâ, subdeclivi, posticè rectâ vel concavâ, declivi ; parte posticâ angustè subtruncatâ : flexurâ magnâ : niveâ : striis concentricis exilissimis : apicibus acutis : ligamento parvo : dentibus cardinalibus parvis, lateralibus obsoletis. Long. $17^{\prime \prime \prime} .8$; alt. $10^{\prime \prime \prime} .1$; lat. $7^{\prime \prime \prime} .6$.

Tellina simulans. T. t. subovatâ, solidâ, subconvexâ, subinequilaterali; margine veutrali vix excurvatá: margine anticá rotundatá; margine dorsali anticò vix excurvata, posticè subrecta, declivi; parto postica obliquò truncuta: flexura parvâ: alba, ad mediam partem roseo tincta : nitidâ : sulcis onoentriois crebris, regularibus, profundis, anticè et posticò æequalibus: ligamento brevi, conspicuo: areâ dorsali posticâ ab angulo umbonali finitâ: dentibus lateralibus subobsoletis. Long. $28^{\prime \prime \prime} .7$; alt. $17^{\prime \prime \prime} .8$; lat. $7^{\prime \prime \prime} .6$.

Tellina vioina. T. t. hrevissimâ, subovatâ, solidâ, convexâ, subequi* laterali; margine ventrali rotundatâ, interdum prope flexuram subincurvatâ; margine anticâ latè rotundatâ; margine dorsali subrectâ, utrinque deolivi; parte posticâ subtruncatâ: flexurâ parvâ: albidâ, interdum flavo tinctâ ; interdum rubrâ, coeruleo tinctâ, vel canescente; interdum albidâ, lineis purpureis angulatis ad umbones-vel radio antico purpureo-ornatâ : striis profundis concentricis erebris inequalibus : ligamento brevi, conspicuo : dentibus lateralibus parvis. Long. $24^{\prime \prime \prime} .1$ : alt. $19^{\prime \prime \prime} .8$; lat. $10^{\prime \prime \prime} .1$.

Petricola cognata. P.t. pholadiformi : albidá; areâ superâ posticâ 
striis exilibus æqualibus crebris radiatA; ared inferd postick lineis elevatis exilibus inequalibus radiata ; parte dimidiê anticâ costis-a squamis fornicatis crassis parvis instructis_radiata : umbonibus subplanulatis; limbo ventrali anticè pectinato. Long. $23^{\prime \prime \prime} .4$; alt. $10^{\prime \prime \prime} .7$; lat. $11^{\prime \prime \prime} .2$.

Amphidesma nicolor. A. t. elliptica, vix flexuosâ, inequilaterali, posticè majori ; margine dorsali posticè subconcavâ ; marginibus alteris rotundatis : albida, propo apices purpureâ; intus areâ purpurea majori : prope apices lævi aliunde lineis exilibus concentricis et striis radiantibus crebris exilissimis-postícè microscopieis, divaricatis-ornatá : apicibus parvis, prominentibus : umbonibus convexis. Long. $21^{\prime \prime \prime} .6$; alt. $18^{\prime \prime \prime} .8$; lat. $10^{\prime \prime \prime} .7$.

Ampindesma proximum. A. t. suborbiculari, subflexuosâ, subinequilaterali ; margine dorsali anticè concavâ, posticè subexcurvatâ; parte postica subtruncata ; marginibus aliunde rotundatis : nived : epidermide tenui, lutescente vel atro-fusca : parte mediá et posticá lineis elevatis subdistantibus exilibus oruat ; striis exilissimis radiatá : apicibus parvis approximatis: umbone sinistrâ quàm dextrâ convexiore : lunulâ et pube angustis, concavis. Long. $45^{\prime \prime \prime} .8$; alt. $40^{\prime \prime \prime} .1$; lat. $20^{\prime \prime \prime} .8$.

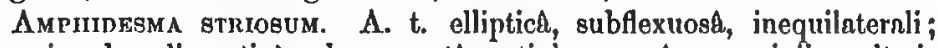
margine dorsali posticè subexcurvatâ, anticè concavâ ; marginibus alteris rotundatis: pallídò flavâ: lineis elevatis concentricis exilibus crebris et striis radiantibus creberrimis exilissimis : apieibus parvis approximatis : umbonibus convexis. Long. $20^{\prime \prime \prime} .1$; alt. $18^{\prime \prime \prime}$; lat. $8^{\prime \prime \prime} .4$.

Amphidesma tortuosum. A. t. compressâ, subequilaterali, suprà angulari, infrà rotundatâ ; margine dorsali posticè vix excurvatâ, ánticè vix concavâ; angulum circa $125^{\circ}$ continenti ; narginibus alteris rotundatis : flexura magnâ : albidâ : rugis concentricis crebris, a striis radiantibus exilissimis trajectis: apicibus minimis, approximatis : umbone sinistro planato, dextro convexo: lunula et pube angustis, profundis. Long. $31^{\prime \prime \prime} .7$; alt. $28^{\prime \prime \prime}$; lat. $8^{\prime \prime \prime} .9$.

Amphidesma ventricosum. A. t. suborbiculari, subequilateralí, ventricosâ, flexuosâ ; margine dorsali utrinque subrect rotundatis: albidâ, pallido fusco zonatâ : striis concentricis inæqualibus ; striis radiantibus exilissimis creberrimis : apieibus parvis, approximatis: umbonibus perconvexis. Long. $17^{\prime \prime \prime} .8$; alt. $15^{\prime \prime \prime} .7$; lat. $9^{\prime \prime} .1$.

Anstiva alta. A. t. ovata, brevi; anticè subangulata et flexuosá; marginibus aliunde rotundatis : albidâ, margaritaceâ : epidermide tenui, fusco-lutescente: exilíssimè agrinatá: apicibus parvis, prominentibus, approximatis: umbonibus subconvexis : intùs post dentem cochleariformem profundè sinuatâ. Long. $50^{\prime \prime \prime} .4$; alt. $34^{\prime \prime \prime} .3$; lat. $17^{\prime \prime \prime} .8$.

Pandora cornuta. P. to elongatâ, ovatá, perinequilaterali ; parte posticâ longiore et alteriore; margine dorsali subrectâ ; posticè rostratâ; margine posticâ suprà profundè excavatâ ; margine ventrali rotundatá : albidâ, margaritacể : umbone dextro posticè angulato : apicibus inconspicuis: umbonibus subæqualiter subconvexis. Long. $15^{\prime \prime \prime} .2$; alt. $10^{\prime \prime \prime} .7$; lat. $2^{\prime \prime \prime} .8$.

Poтамомy squalis. P. to subovata, subequilaterali, subinequivalvi; 
margine postick subangulatâ ; marginibus alteris rotundatis : albâ : epidermide pallido fusco: angulo umbonali postica haud prominente; umbone dextro inflato: apicibus parvis : dentibus parvulis : dente sinistrâ ad mediam carinatâ. Long. $10^{\prime \prime \prime} .8$; alt. $16^{\prime \prime \prime} .8$; lat. $10^{\prime \prime \prime} .7$.

Potamomya inflata. P. t. ovata, ventricosa, inequilaterali, subinequivalvi, posticè inter angulos duos umbonales subtruncatá; margine ventrali haud multùm excurvatâ; margine anticâ rotundatâ : alba: epidermide fusco-lutescente : apicibus parvis : umbonibus inflatis : dentibus parvis: dente sinistrâ ad mediam carinatâ. Long. $17^{\prime \prime \prime} .8$; alt. $14^{\prime \prime \prime} .5 ;$ lat. $8^{\prime \prime \prime} .4$.

Potamomya trigonalis. P. t. solidâ, triangulari, subinequivalvi, subequilaterali ; margine dorsali posticè subexcurvatâ ; anticè angulatâ ; posticè rotundata ; infrà subrectâ : albâ : epidermide fusco lutescente : angulo umbonali postico acuto : apicibus magnis, prominentibus : dentibus robustis; dente sinistrâ ad mediam carinatâ. Long. $24^{\prime \prime \prime} .1$; alt. 20 "'.3 ; lat. 14 "'.2.

Corbula rubra. C. t. subovatâ, subinequivalvi, subinequilaterali, posticè acuminatâ, infrà arcuatâ, anticè rotundatâ : rufâ, anticè radio brevi albo, anteriùs maculâ atro-rubrâ-ornatâ: striis concentricis exilibus; striis radiantibus exilissimis: umbonibus inflatis: dentibus parvis. Long. $7^{\prime \prime \prime} .9$; alt. $4^{\prime \prime \prime} 8$; lat. $3^{\prime \prime \prime} .5$.

Soleourtus AFFints. S. t. elongata, subcylindrick, utrinque rotundatá: albâ: epidermide stramineâ: apicibus subposticis: ligamento lato: nymphis callosis: dentibus parvis ; sinistrâ unâ ; dextris duobus. Long. $57^{\prime \prime \prime}$; alt. $20^{\prime \prime \prime} .3$; lat. $14^{\prime \prime \prime}$.

Solen RUdis. S. t. solida, rectá vel subrectá; posticè truncata ; anticè rotundata ; limbis anticis crassissimis : alba : epidermide fusco lutescente, crassa, deciduâ, trans margines productâ; striis exilissimis nonnullis radiatâ : apicibus ab extremitatem anticam 1 longitudinis totius distantibus: ligamento magno: nymphis callosis: dentibus in testis senioribus magnis. Long. $147^{\prime \prime \prime}$; alt. $33^{\prime \prime \prime}$; lat. $25^{\prime \prime \prime .4 . ~}$ 


\section{N D E X}

OF

\section{F A M I I E S A N D G E ERA.}

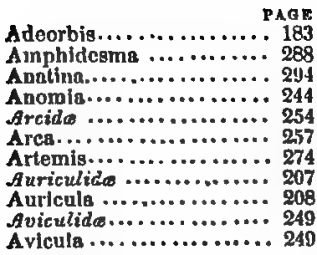

Buccinum ............. 67 Brllida................. 214 Bulls ................. 214

Culyptraide............ 217

Calyutrax................ 219

Cancellaria.............. 132

Capsa .................... 276

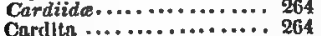

Carditn ................. 204

Cassis.................. 102

Cassis .................... 150

Chamide ... ........... 253

Chams................ 253

Chemnitzis .............. 164

Chiton ................. 242

Cingula ................ 18t

Coccum ................ 160

Columbells ............ 81

Conus .................. 104

Corbultida............... 294

Corbula................ 297

Crassatella ............. 292

Crepidula .............. 225

Cumingia ............... 287

Cyclootomida............. 212

Cypraida............. 29

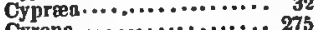

Cytheres............... 272

Dolium ............... 73

Donax ............... 277

Erato ................ 39

Sulimida.............. 198

Eulima .................. 198

Fasclolarla............ 129

\begin{tabular}{|c|c|}
\hline 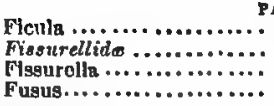 & $\begin{array}{l}128 \\
1235 \\
235 \\
129\end{array}$ \\
\hline Gouldia.................. & .275 \\
\hline $\begin{array}{l}\text { Haliotide } \ldots \ldots \ldots \ldots \ldots \ldots \\
\text { Hipponyx............... }\end{array}$ & $\begin{array}{l}216 \\
217\end{array}$ \\
\hline 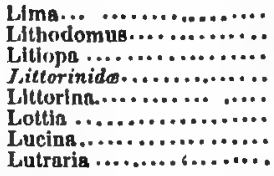 & $\begin{array}{r}248 \\
231 \\
163 \\
. \\
160 \\
170 \\
241 \\
.276 \\
\text {. } 293\end{array}$ \\
\hline
\end{tabular}

Mangelia............... 148

Marginella .............. 40

Mitride.............. 49

Mitra ................. 42

Modioln............... 251

Monoceros.............. 74

Mulinia.................. 293

Muricide.............. 115

Murex................. 121

Mytilide ............ 250

Mytllus................. 251

Nagsa.................. 59

Natica.................. 200

Neritide............. 200

Nerita................... 204

Nerlitina................. 206

Nucula . ................ 254

Ollva................. 48

Oniscia ................ 104

Orblcula................. 303

Ostraida.............. 244

Ostres................ 245

Orula................ 90

Pandora.................. 295

Patellida................ 241

Patella.................. 241

Pectenids................ 247

Pecten................. 247
PAG

..........256

Pedipes.............. 207

Perna................ 250

Petricolide..............2e6

Petricola................ 286

Pholadede ............. 301

Pholas ................ 30

Pinnb................. 250

Plongxis............... 58

Plenrotomn.............. 137

Polnmomya............ 295

Purpurida ............ 45

Purpurn ............... 70

Pyramidella............ 200

Pyrule............... 127

Ronella ................ 118

Ricinula, ............... 101

Rlssoa ................ 177

Snxicavg. ............. 287

Scalaria, .............. 197

Siphonaria.............. 239

Solarium.............. 190

Solecurtus............... 300

Solenida ................ 300

Solen ................ 300

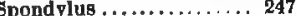

Siomaiella............. 216

Strombide................ 104

Strombus................ 111

Tellenida ............. 276

Tellins.................. 279

Terebra................ 45

Tornatellides............. 200

Triphoris ............. 158

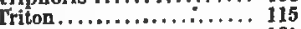

Trockida................ 181

Trochus................ 100

Truncatella ............. 212

Turblnella.............. 130

Turbo.............. 194

Turritella........... 160

Venerida $\ldots . \ldots \ldots \ldots \ldots, 260$

Venus.................. 269

Vermetida .............. 216

Vermetus .............210

vitrinelia $\ldots \ldots \ldots \ldots \ldots \ldots \ldots .184$ 



\section{N D E X.}

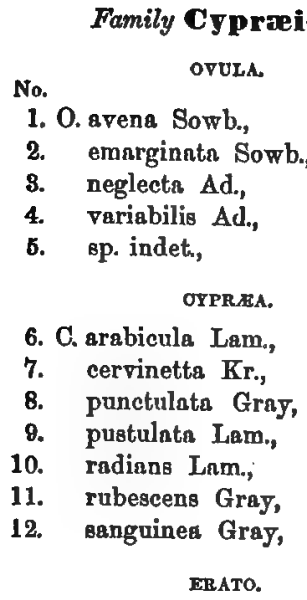

13. F. cypræola Sowb.,

14. M. minor Ad.,

15. sapotilla Hinds,

\section{Family Mitridae.}

MTTRA.

16. M. funiculata Rv,

17. lens Wood,

18. nucleola Lam.,

19. solitaria Ad,

20. tristis Brod.,

Family Purpuridse. TERESIA.

21. T. elata Hinde,

22. larvæformis Hinds,

23. robusta Hinds,

24. specillata Binds,

25. tuberculosa Hinds,

No.

26. T. varicosa Hinds,

Page

47

27. sp. indel. $a$,

28. " $b$,

29. " $c$,

30. " d

31. " $e$,

oLIVA.

32

82. O. angulata Lam., 48

33. araneosa Lam. 49

34. inconspicus Ad., 50

35. pellucidn Rv., 51

36. porphyrin Linn., 62

37. Bemistriata Gray, 53

38. testacea Lam., $\quad 54$

39. undatella Lam., 55

40. venulats $\mathrm{Lam}_{\text {, }} \quad 56$

41. volutella Lam., 5 ?

PLANAXI8.

42. P. planicostata Sowb.,

58

NABBA.

40

40

42

42

43

44

44
43. N. canescens Ad.,

59

44. collaria Gould,

$44 a$. " var. $a$,

45. corpulenta Ad.,

46. gemmulosa Ad.,

47. glauca Ad.,

48. Iuteostoma Brod.,

49. nodifera Powis,

50. parodus (Triton) $\mathrm{B}$

51. Panamengis 4 d

52. proxima

62. proxina

54. striata $\mathrm{Ad}$., 65

55. versicolor $A d$, $\quad 66$

55 a. " var. striatula Ad., 66

56. Wilsoni Ad., 6 T

BECOTNUM.

57. B. crassum (Phos) Hind, 
No.

58. B. distortum Wood,

59. insigne $R v$,

60. lugubre Ad,

61. pagodus Rv.,

62. pristis Desh.,

63. ringens $R v$.,

64. sanguinolentum Ducl.,

65. Stimpsonianum Ad.,

DOLIUM.

66. D. ringens Swains, MONOCEROS.

67. M. brevidentatum Wood,

68. cingulatum Wood,

PURPURA.

69. P. Carolensis RV.,

70. foveolata Ad,

71. kiosquiformis Ducl,

72. sp. indet.,

73. melo Duel.,

74. osculans Ad.,

75. tecta Wood,

76. undata Lam.,

COLUMBRLLA.

77. C. atramentaria Sowb.,

78. bicanalifera Sowb.,

78. Boivinii Kr.,

80. conspicua Ad.,

81. costellata Sowb.,

82. diminuta Ad.,

88. dorsata Sowb.,

84. fluctuata Sowb.,

85. fulva Sowb.,

86. fuscata \$owb.,

87. gibberula Sowb.,

88. gracilis Ad.,

89. guttata Sowb., posted O. cribraria Sowb.

90. høemastoma Sowb.,

91. harpiformis Sowb.,

92. labiosa Sowb.,

93. lyrata Sowb.,

94. major Sowb.,

95. modesta Powis,

96. mœsta Ad,.

97. nigricans Sowb.

98. parva Sowb.,

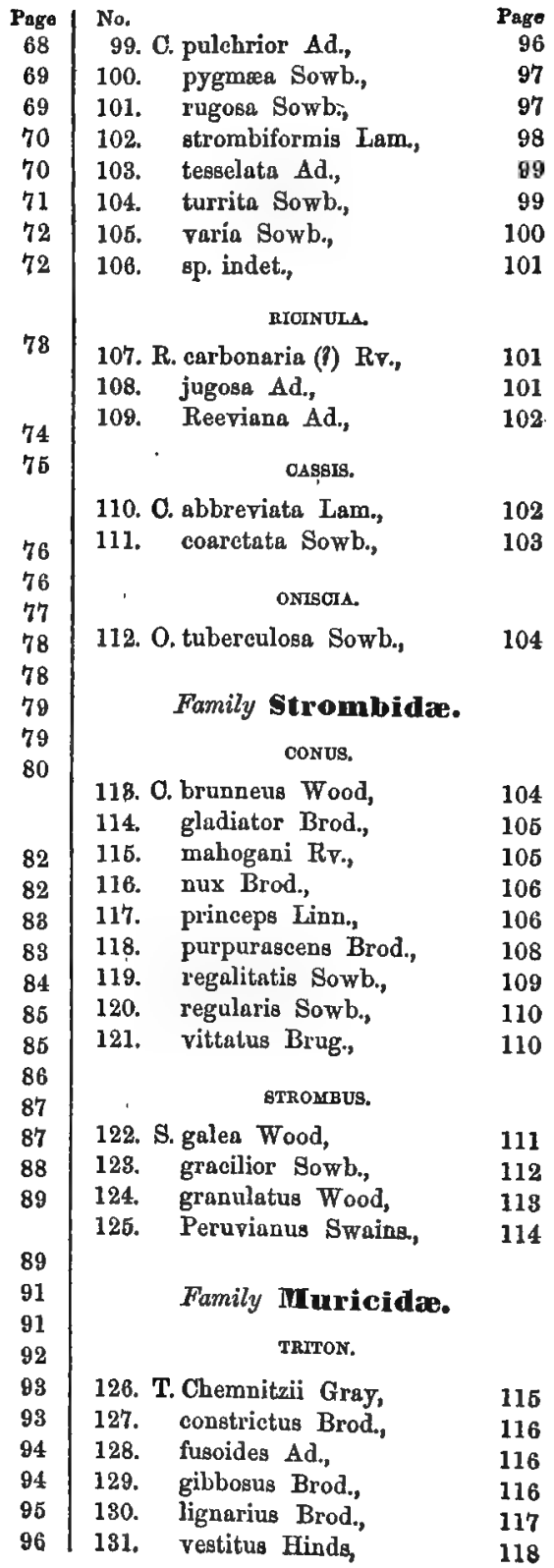




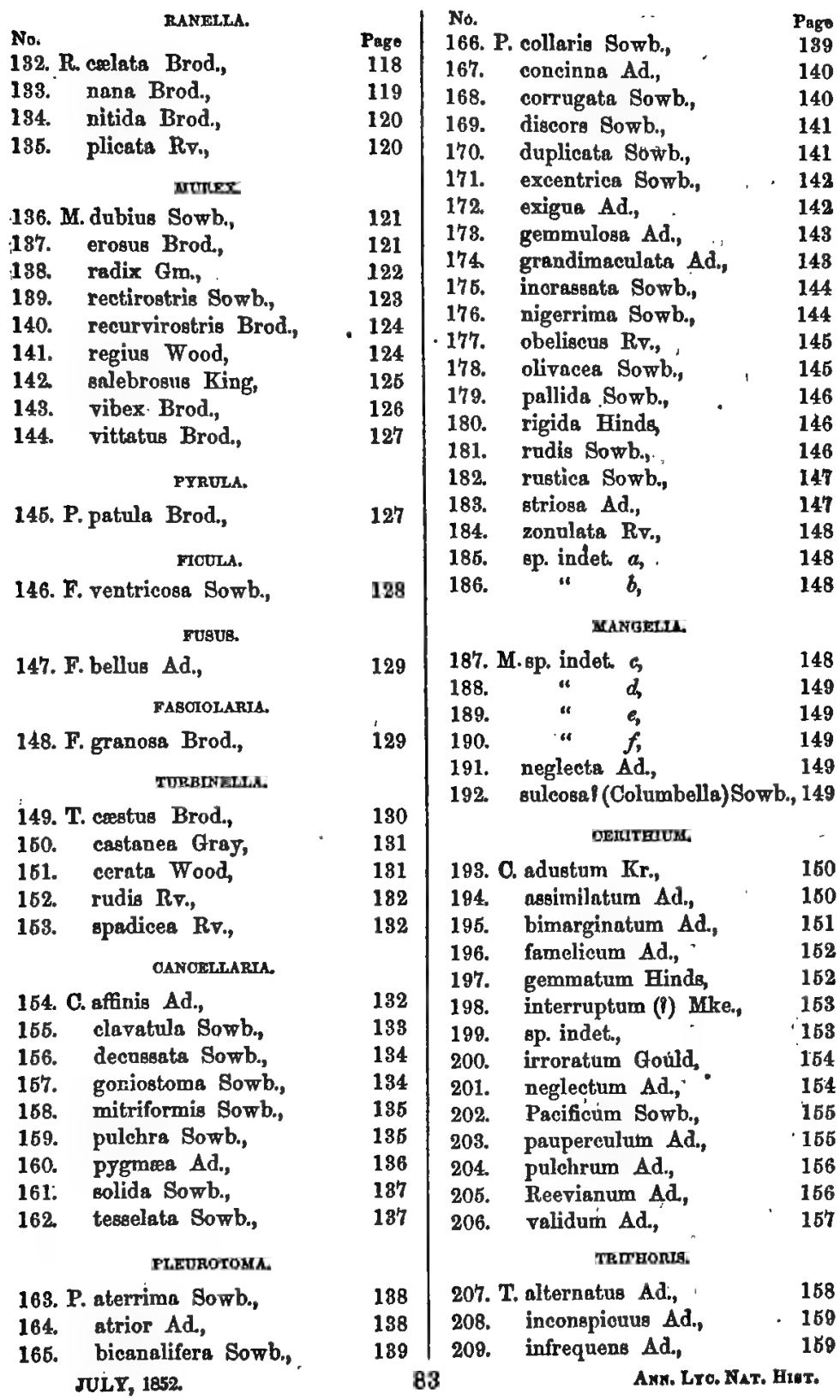


No.

Family Littorinidae.

TURRITETLA.

210. T. Banksii Rv.,

OECUM.

211. C. diminutum Ad.,

212. eburneum Ad.,

213. firmatum $\mathrm{Ad}$,

214. læve Ad.,

215. laqueatum $\Delta d$.,

216. monstrosum $A d$,

217. parvum Ad,

218. pygmæum Ad.,

CIIEMNITZIA.

219 C. aculeus Ad,

220. acuminata Ad.,

221. affinis Ad.,

222. clathratula Ad.,

223. communis Ad.,

224. gracilior Ad.,

225. major Ad.,

226. marginnta $\mathrm{Ad}$,

227. Panalnensis Ad.,

228. similis Ad.,

229. striosa Ad.,

230. turrita Ad.,

LITTORNA.

231. L angiostoma Ad.,

232. aspera Phil,

233. atrata Ad.,

284. conspersa Plil.,

235. excavata Ad,,

236. fasciata Gray,

237. foveata Ad.,

238." megasoma Ad.,

239. parvula (?) Phil.,

240. pulchra Swains,

241. puneticulata Phil,

242. varia Sowb.,

\section{RIBSOA.}

248. R. clnndestins $A d$,

244. firmata Ad.,

245. fortis Ad.

446. inconspicua $\mathrm{Ad}$,

247. infrequens $\mathrm{Ad}$,

248. Janus Ad.
Page

160

161

161

161

162

162

162

163

163

164

164

165

165

166

167

167

167

168

168

169

169

170

170

171

172

172

173

173

174

174

175

176

176

177

177

178

178

179

179
No.

249. R. notabilis Ad.,

250. scalariformis Ad.,

251. sp. indet.,

\section{Family Trochidae.}

ONNGULA.

252. C. inconspicua Ad.,

181

253. paupercula Ad., 181

254. terebellum Ad., $\quad 182$

255. turrita Ad., 182

LITIOPA

256. L. saxicola Ad.,

188

ADEORBIS.

257. A abjecta Ad.,

189

VITRINELLA.

258. V. concinna Ad.,

184

259. exigua Ad., 184

260. Janus Ad., 185

261. minuta Ad., 186

262. modesta Ad, 186

263. Panamensis Ad, 186

264. parva Ad., 187

265. perparva Ad., 187

266. regularis Ad, 188

267. seminuda Ad, 188

268. tricarinata Ad., 189

269. valvatoides Ad, $\quad 189$

BOLARIUM.

270. S. sp. indet. $a_{3} \quad 190$

$271 . \quad$ " b , 190

272. "

TROOHUS

273. T. catenulatus Phil., $\quad 190$

274. coronulatus Ad, $\quad 191$

275. Lennus Ad., 191

276. lina Phil., 192

277. lividus Plil, 192

278. Panamensis Phil, 193

279. pellis-serpentis Wood, 193

280. reticulatus Wood, 194

TURBO.

281. T. Buschii Phil,

195

282. phasianella Ad., 195

283. rutilus Ad. 
No.

284. T. sexosus Wood,

SOALARTA.

285. S. hexagona Sowb.,

286. obtusa Sowb.,

287. sp. indet. $a$,

288. " $b$,

289. " c,

\section{Family Eulimidae.}

FULDMA.

290. E iotn $\Lambda d_{\text {, }}$

201. rectn $\Lambda d$,

282. solitaria Ad.,

\section{Family Tormatellida.}

293. P. sp. indet.,

PYRAMTDELLA.

294. conice Ad,

\section{Family Neritidae.}

\section{NATIOA.}

295. N. Chemnitzii Mke,

296. Iurida Phil.,

297. otis Brod.,

298. Salangonensis (†) Recl,

299. Souleyetiana Recl,

800. virgines! Recl.,

301. sp. indet. $a$,

302 " b,

303. " $e$,

NERTIA.

304. N. seabricosta Lam.,

305. - sp. indet,

\section{NETUTINS.}

306. N. Guayaquilensis Sowb, 807. picta Sowb.,

\section{Family Aurieulidae.} PEUTEES.

308. P. angulate Ad., AURIOUYA.

309. A. acuta Orb.,

\begin{tabular}{c|} 
Page \\
196 \\
\\
197 \\
198 \\
198 \\
198 \\
198
\end{tabular}

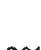

200

201

201

201

202

202

203

203

203

204

204

205

206

206

207

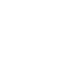

208
No.

310. A concinna Ad,

811. infrequens Ad,

Page

208

209

$\begin{array}{ll}\text { 312. Panamensis Ad, } & 209 \\ \text { 313. stagnalis Pet., } & 210\end{array}$

314. Tabogensis Ad., 211

315. trilineata Ad., 212

316. sp. indet, 212

\section{Family Cyclostomidae.}

- Truncatelia.

317: T. Bairdiana Ad., 213

318. dubiosa Ad., 218

Family Bullidae.

BuLLA.

'319. B. infrequens $A d$., 214

320. luticola Ad, 215

321. punctulata $A$. Ad, 215

322. sp. indet, 215

\section{Family Vermetidae.}

323. V.glomeratus Rous., 216

324. Panamensis Rous, 216

Family Faliotidae. BTOMATELLA.

325. S. inflata Ad,

\section{Family Calyptraeidae.} HIPPONYX.

326. Hrsp. indet.

327. barbata Sowb.

328. Panamensis Ad.,

329. radiata Sowb,

\section{OALYPTRAA.}

330. C. aberrans Ad.,

331. aspersa Ad, 219

332. cepacea Brod, 220

333. conica Brod, 220

334. dentata Mke, 221

335. hispida Brod., 221

330. imbrienta Brod., 222

337. maculata Brod, 223

338. planulata $\mathrm{Ad}$, " 223 
11..

889. C. radiata Brod.,

'840. regularis Ad.,

341. umbrella Desh.,

342. unguis (i) Brod,

CREPIDULA.

849. C. cerithicola Ad.

844. echinus Brod,

845. excavata Brod.,

346. hepatiea (?) Desh.

847. incurva Brod.,

348. Lessoni Brod,

349. squama Brod.,

350. unguiformis (1) Lam.,

851. nivea Ad.,

352. osculans Ad.,

858. rostrata $\mathrm{Ad}$,

\section{Family Fissurellidae.}

nEgUEELM.

854. F. wqualis Sowb.,

855. alta Ad.,

856. macrotrema Sowb.,

857. microtrema Sowb,

358. mus $\mathbf{R r}$.,

359. nigropunctata Sowb.,

360. ostrina Rv.

361. Virescens Sowb.,

\section{BIPHONADIA}

362. S. characteristica Rv. 239

863. costata Sowb, 239

364. gigas Sowb., 239

365. maura Sowb., 240

366. pica Sowb., 240

\section{LOTTL.}

867. L patina (?) Rathke,

$867 a$ " var. $u_{3}$

368. sp. indet. $a$

369. "a $b$,

370. "

\section{Family Patellida.}

871. P. sp. indet.,

CHITON.

872: C. clathratus $R r_{\text {n }}$

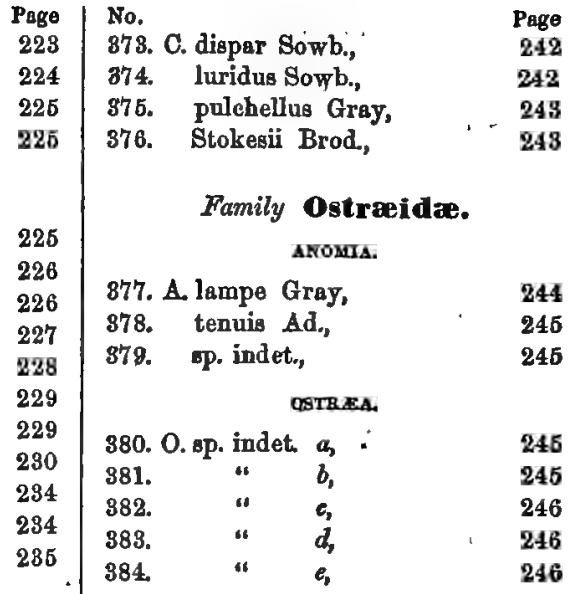

Family Pectenidae.

BTONDYLUB.

885. B. Lamarckii (i) Sowb., 247

886. sp. indet.,

Proter.

387. P. Inca Orb.,

247

888. Tumbezensis Orb., 248

ITSA.

389. L. angulata Sowb,

890. arcuata Sowb.,

Family Aviculidae.

$\triangle$ VIOULA.

891. A. margaritifera ?

392. sterna Gould,

393. P. sp. indet, $a$,

394.

$b$,

250

\section{Family Mytilidae.}

PINA.

395. P. maura Sowb.,

89

tuberculose Sowb.,

MYTLUS

242 897. M. ep. indet. 
No.

LTHODONUA

898. L. sp. indet. $a_{\text {, }}$

ModrotA.

899. M. semifusca (I) Lam,

400. sp. indet. $a$

401. " $b$,

402. "

403. " d

404. " .

\section{Family Chamidze.}

OHAMA.

405. C. Buddiana Ad.,

406. corrugata Brod,

407. echinata Brod,

\section{Family Arcidze.} NUCULA.

408. N. Elenensis Sowb.,

409. exigua Sowb.,

410. polits Sowb.,

PROTUROULUB.

411. P. asgimilis Sowb.,

412. maculatus (l) Brod,

AROA.

413. A alternata Sowb.,

414. aviculoides $R \nabla$. ,

415. etharginata Sowb.,

416. gradata Brod,

417. grandis Brod.,

418. mutabilis Sowb.,

418. pholadiformis Ad.,

420. Reeveana "Orb.,

421. reversa Sowb.,

422. similis Ad.,

423. solide Sowb.,

424. Tabogensis Ad,

425. tuberculosa Sowb.,

426. sp. indet,

Family Cardidiae.

OARDITA

427. C. affinis Sowb.,

428. laticostata Sowb.,

429. radiata Sowb.,

430. graniferum Brod, JULY, 1852.

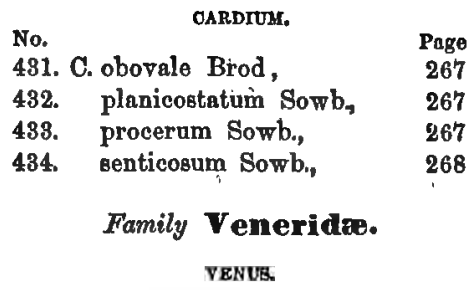


No.

469. T, cognata Ad.,

460. Columbiensis Hanley,

461. concinna Ad.,

462. crystallina Chem,

468. Cumingii Hanley,

464. Dombei Hanley,

465. felix Hanley,

466. laceridens Hanley,

467. prora Hanley,

468. puella Ad.,

469. rubescens Hanley,

470. siliqua Ad.,

471. simulans Ad.,

472. sincera Hanley,

473. vicina $\mathrm{Ad}_{\text {., }}$

474. sp. indet. $a$,

475 . " $b$,

476. " $c$,

\section{Family Petricolidae.}

PETRICOLA.

477. P. cognate Ad.,

\section{BAXIOAYA.}

478. S. tenuis (?) Sowb.,

\section{Family Mactrida.}

cumingia.

470. C. coarctata Sowb.,

480. trigonularis Sowb.,

481. sp. indot. $a$,

482. " क

488. " $c$,

484. " d

AMPHLESMA.

485. A. bicolor Ad.,

486. ellipticum Sowb.,

487. proximum Ad.,

488. pulchrum Sowb.,

489. striosum Ad.,

490. tortuosum Ad.,

491. Ventricosum Ad.

$$
\text { crassatella. }
$$

492. C. gibbosa Sowb.,

$$
\text { MULINIA. }
$$

493. M. donaciformis Hanley,

494. ventricosa Gould,
Page

279

280

280

281

281

282

282

282

288

283

283

284

284

285

285

286

286

286

286

287

288

288

288

288

288

288

289

289

290

291

291

292

292

293

203 $\begin{array}{lr}\text { No. LUtrarta. } & \text { Page } \\ \text { 495. I. elegans Sowb., } & 293 \\ & \text { Muctra. } \\ \text { 496. M. velata Phil., } & 294 \\ \text { 496 a. " var. } a, & 294\end{array}$

Family Corbulidae.

ANATINA.

497. A, alta Ad.,

294

PANDORA.

498. P. cornuta Ad.,

295 .

POTAMOMYA.

499. P. requalis Ad.

295

600. inflata Ad.,

501. trigonalis Ad.,

296

296

CORBULA.

502. C. bicarinata Sowb.

297

503. biradiata Sowb, 297

504. obesa Hinds, 298

505. ovulata Sowb, . 298

506. rubra Ad., 299

507. tenuis Sowb., 299

508. sp. indet. $a, \quad 300$

509. $" b_{3} \quad 300$

\section{Family Solenidae.} BOLEOURTU.

510. S. affinis Ad.,

800

BOLEN.

511. S. rudis Ad., *

300

\section{Family Pholadida.}

PHOLAS.

512. P. crucigera Sowb, 301

513. tubifera Sowb., 302

514. xylophaga $\nabla a l$. (non al.), 302

515. sp. indet. $a, \quad 302$

516. “ $b$, 302

Class Hrachiopoda.

ORBICULA.

517. O. Cumingii Brod, 


\section{E R A T A.}

Page 20, 1ith line from the top, for Veritine read Neritina.

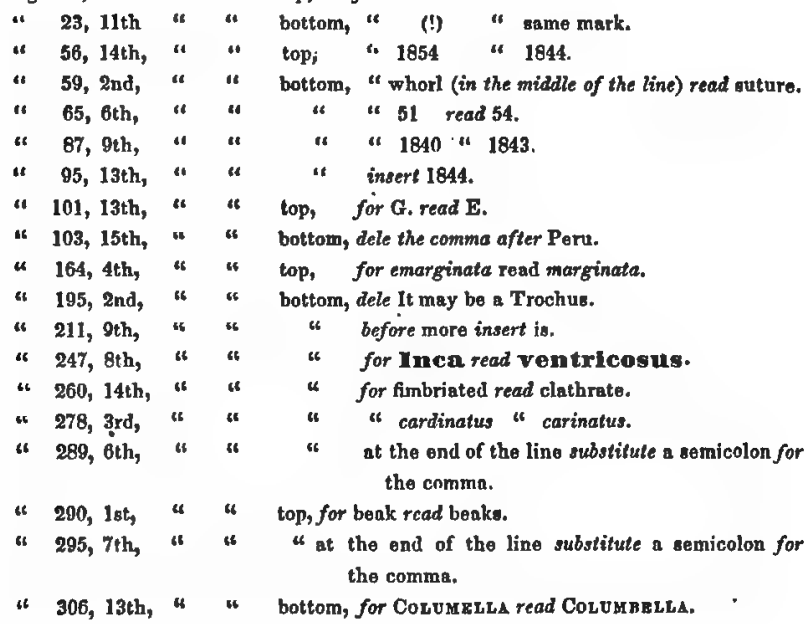



This preservation photocopy was made and hand bound at BookLab, Inc. in compliance with copyright law. The paper,

Weyerhaeuser Cougar Opaque Natural, meets the requirements of ANSI/NISO

Z39.48-1992 (Permanence of Paper).

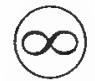

Austin 1994 








\section{.}


